\title{
MARKET ANALYSIS OF
}

\section{S IALE OIL CO-PRODUCTS}

\section{NOTICE}

PORTIONS OF THIS REPORT ARE ILLEGIBLE. It has been reproduced from the best avastabse copy to permit the proadest

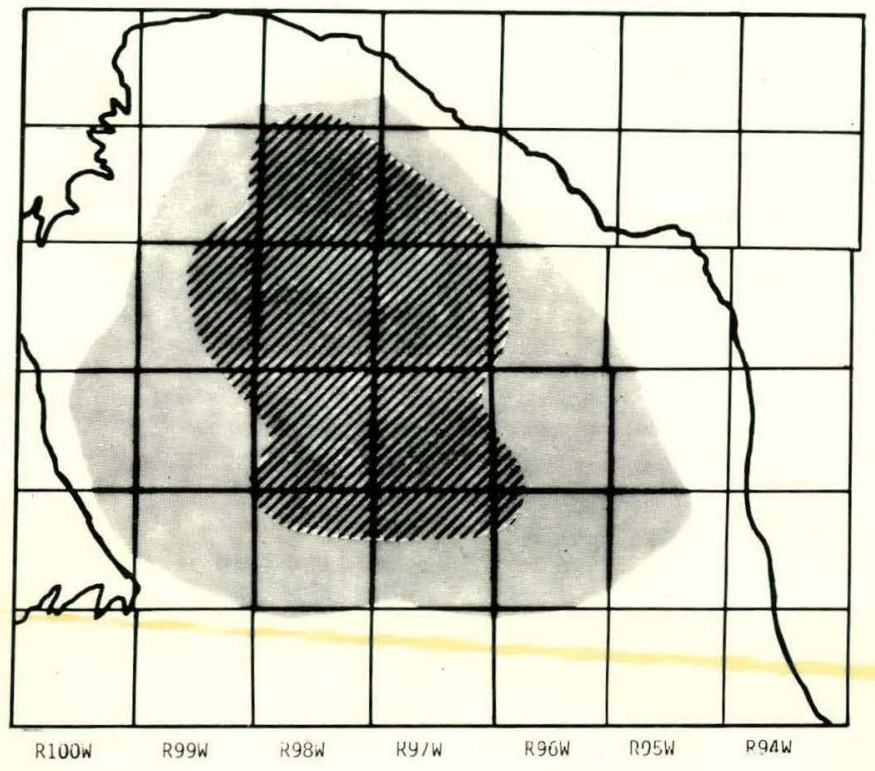

\section{APPENDICES}

PREPARED BY

LEWIN \& ASSOCIATES, INC.

E.G. HIGGINS FEDERAL, INC.

ENERGY DEVELOPMENT CONSULTANTS, INC.

\section{PREPARED FOR}

\section{U.S. DEPARTMENT OF ENERGY \\ RESOURCE APPLICATIONS}




\section{DISCLAIMER}

This report was prepared as an account of work sponsored by an agency of the United States Government. Neither the United States Government nor any agency Thereof, nor any of their employees, makes any warranty, express or implied, or assumes any legal liability or responsibility for the accuracy, completeness, or usefulness of any information, apparatus, product, or process disclosed, or represents that its use would not infringe privately owned rights. Reference herein to any specific commercial product, process, or service by trade name, trademark, manufacturer, or otherwise does not necessarily constitute or imply its endorsement, recommendation, or favoring by the United States Government or any agency thereof. The views and opinions of authors expressed herein do not necessarily state or reflect those of the United States Government or any agency thereof. 


\section{DISCLAIMER}

Portions of this document may be illegible in electronic image products. Images are produced from the best available original document. 
DOE/RA/134014-TI $6=$

\title{
MARKET ANA .YSIS OH

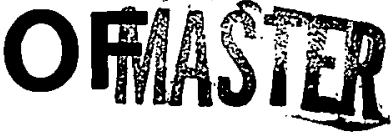

\section{SHALE OIL CO-PRODUCTS}

\author{
PREPARED BY \\ LEWIN \& ASSOCIATES, INC. \\ - IN ASSOCIATION WITH - \\ E.G. HIGGINS FEDERAL, INC. \\ $\mathrm{DOE} / \mathrm{RA} / 34014--\mathrm{T} I$ \\ DE82 011718
}

PREPARED FOR

U.S. DEPARTMENT OF ENERGY

RESOURCE APPLICATIONS

OFFICE OF OIL SHALE RESOURCE APPLICATIONS

UNDER CONTRACT NO. DE-AC01-79RA 34014

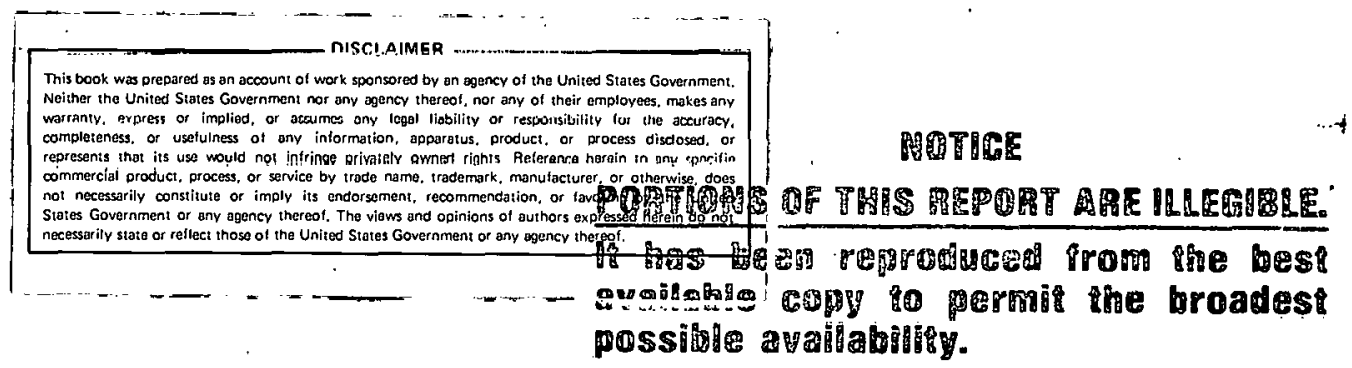

NOTICE

This report was prepared as an account of work sponsored by an agency of the United States Government. Neither the United States Government nor any agency thereof, nor any of their employees, makes any warranty, express or implied, or assumes any legal liability or responsibility for the accuracy, completeness, or usefulness of any information, apparatus, product, or process disclosed, or represents that its use would not infringe privately owned rights. Reference herein to any specific commercial product, process, or service by trade name, trademark, manufacturer, or otherwise, does not necessarily constitute or imply its endorsement, recommendation, or favoring by the United States Government or any agency thereof. The views and opinions of authors expressed herein do not necessarily state or reflect those of the United States Government or any agency thereof. 


\section{ACKNOWLEDGEMENTS}

The following individuals and organizations provided their time and talents to this study:

- Lewin and Associates, Inc.

Mr. Vello A. Kuuskraa

Mr. Edgar C. Hammershaimb

- E. G. Higgins Federal, Inc.

Mr. E. G. Higgins

- Energy Deve lopment Consultants, Inc.

Mr. R. Trent

Mr..J. Broz

Beyond these individuals, the study staff acknowledges the valuable contributions and efforts of other members of the staff in all three companies to the technical and clerical support of this study. 


\section{Appendix 1}

\section{TABLE OF CONTENTS}

\begin{tabular}{|c|c|}
\hline $\begin{array}{l}\text { Chapter 1 } \\
\text { INTRODUCTION: OBJECTIVES AND SCOPE } \\
\text { Study Overview } \\
\text { Methodology } \\
\text { Summary of Scope. }\end{array}$ & $\begin{array}{l}-I \cdot 1- \\
-I .1- \\
-I .2- \\
-I .4-\end{array}$ \\
\hline $\begin{array}{l}\text { Chapter } 2 \\
\text { ENGINEERING AND CONCEPTUAL PROCESS DESIGN } \\
\text { ANALYSIS } \\
\text { General Scope } \\
\text { MINING } \\
\text { Description and Assumptions } \\
\text { Mining Equipment } \\
\text { Mine Water } \\
\text { Mine Development and Operation } \\
\text { CONVEING, PRIMARY CRUSHING AND STORAGE } \\
\text { NAHCOLITE RECOVERY UNIT } \\
\text { Description and Assumptions } \\
\text { Equipment } \\
\text { Nahcolite Properties and Processes } \\
\text { RETORTING/OIL AND GAS RECOVERY } \\
\text { Description and Assumptions } \\
\text { Retorting Yields } \\
\text { MineraI Carbonate Decomposition } \\
\text { ALSAR UNIT } \\
\text { Review: Nahcolite and Dawsonite Chemistry } \\
\text { Description and Assumptions: ALSAR Process } \\
\text { Design and Case Analyses } \\
\text { Plant Energy Balance Case (3) }\end{array}$ & $\begin{array}{l}\text {-II.1- } \\
\text {-II.1- } \\
\text {-II.7- } \\
\text {-II.7- } \\
\text {-II.12- } \\
\text {-II.14- } \\
\text {-II.15- } \\
\text {-II.17- } \\
\text {-II.18- } \\
\text {-II.18- } \\
\text {-II.19- } \\
\text {-II.21- } \\
\text {-II.23- } \\
\text {-II.23- } \\
\text {-II.26- } \\
\text {-II.27- } \\
\text {-II.29- } \\
\text {-II.31- } \\
\text {-II.32- } \\
\text {-II.38- }\end{array}$ \\
\hline $\begin{array}{l}\text { Chapter } 3 \\
\text { COST ESTIMATION ANALYSIS: CONCEPTIONAI } \\
\text { PROCESS } \\
\text { FUNDAMENTAL COST ANALYSIS: CASE } 3 \\
\text { Case ( } 3 \text { - Capital Cost Analysis } \\
\text { Capital Cost Scaling } \\
\text { Case (3) - Operating Cost Analysis } \\
\text { PROCESS CONFIGURATION AND COST SENSITIVITY } \\
\text { SUMMARY }\end{array}$ & $\begin{array}{l}\text {-III. 1- } \\
\text {-III.6- } \\
\text {-III.6- } \\
\text {-III.7- } \\
\text {-III.9- } \\
\text {-III.16- } \\
\text {-III.20- }\end{array}$ \\
\hline [BI & B-1 \\
\hline
\end{tabular}


Appendix 1

LIST OF EXHIBITS

Page

\begin{tabular}{|c|c|c|c|}
\hline $\begin{array}{l}\text { Exhibit } \\
\text { Exhibit } \\
\text { Exhibit } \\
\text { Exhibit }\end{array}$ & $\begin{array}{l}2-2 \\
2-3 \\
2-4\end{array}$ & $\begin{array}{l}\text { Resource Definition and Cases Examined } \\
\text { Process Flow Diagram: Case } 3 \\
\text { Product Slates for the Five Cases } \\
\text { Major Plant. Sections of a Commercial }\end{array}$ & $\begin{array}{l}\text {-II.2 - } \\
\text {-II.3 - } \\
\text {-II. }\end{array}$ \\
\hline xhibit & $2-5$ & $\begin{array}{l}\text { Shale Oil/Mineral Co-Products Facild } \\
\text { Mining Equipment Inventory In-Panel } \\
\text { Production Equipment }\end{array}$ & \\
\hline $\begin{array}{l}\text { Exh } \\
\text { ixh } \\
\text { ixh }\end{array}$ & $\begin{array}{l}2-6 \\
2-7 \\
2-8\end{array}$ & $\begin{array}{l}\text { Nahcolite Recovery Unit Case } 3 \\
\text { Circular Grate Retort-Direct-Heated Mode } \\
\text { Aluminum and Soda Ash Recovery } \\
\text { Facilities: Case } 3\end{array}$ & $\begin{array}{l}-\bar{I}(1 \\
-\mathrm{I}\end{array}$ \\
\hline xhibit & $2-9$ & $\begin{array}{l}\text { ALSAR Plant Leaching Section Material } \\
\text { Balance }\end{array}$ & \\
\hline $\begin{array}{l}\text { xh } \\
x \mathrm{xh} \\
\mathrm{xh}\end{array}$ & $\begin{array}{l}2-10 \\
2-11 \\
2-12\end{array}$ & $\begin{array}{l}\text { Product Slates for the Five Cases } \\
\text { ALSAR Unit Inventory: Major Equipment } \\
\text { Energy Requirements for the Shale Oil. } \\
\text { and Co-Product Facility }\end{array}$ & $\begin{array}{l}\text {-II.40- } \\
\text {-II.41- } \\
\text {-II.44- }\end{array}$ \\
\hline ; & & $\begin{array}{l}\text { Case } 3 \text { Inventory: } \mathrm{Me} \\
\text { Purchases }\end{array}$ & $-I$ \\
\hline $\begin{array}{l}\text { Exhi } \\
\text { Exhi } \\
\text { Exhi } \\
\text { Exhi } \\
\text { Exhi }\end{array}$ & $\begin{array}{l}3-2 \\
3-3 \\
3-4 \\
3-5 \\
3-6\end{array}$ & $\begin{array}{l}\text { Case } 1 \text { Unburdened Costs } \\
\text { Case } 2 \text { Unburdened Costs } \\
\text { Case } 3 \text { Unburdened Costs } \\
\text { Case } 4 \text { Unburdened Costs } \\
\text { Case } 5 \text { Unburdened Costs } \\
\text { Cost Scaling Exponents: Major Plant } \\
\text { Sections }\end{array}$ & $\begin{array}{l}- \text { II } \\
\text {-II } \\
\text {-II } \\
\text {-II } \\
\text {-II }\end{array}$ \\
\hline xhibj & & $\begin{array}{l}\text { Capital and Op } \\
\text { of Alumina and } \\
\text { Selected Proces }\end{array}$ & \\
\hline
\end{tabular}




\section{Append ix 2}

\section{TABLE OF CONTENTS}

SUMMARY

INTRODUCTION

Estimates of Capital and Operating Costs

ECONOMIC ASSUMPTIONS

ECONOMIC RESULTS.

Rich Shale, Lean Mineral Cases

Rich Shale, Rich Mineral Cases

Lean Shale, Rich Mineral Case
Page

$-I .1-$

$-1.2-$

$-1.3-$

-II.1-

$-1 \mathrm{II} .1-$

-III.2-

$-I I I .3-$

-III.4- 


\section{LIST OF TABLES AND EXHIBITS}

Table 1 CASE 1 Burdened Costs

- Page

Table 2 CASE 2 Burdened Costs

-III.6-

Table 3 CASE 3 Burdened Costs

- III.7-

Table 4 CASE 4 Burdened Costs

-III.8-

Table 5 CASE 5 Burdened Costs

- III.9-

$-111.10-$

Table 6 Shale Co-Product Study Economic

-III.1I-

Table 7 Shale Co-Product Study Economic

-III.12-

Exhibit 1 CASE 3 Shale 0il Economics

Exhibit 2 CASE 3 Alumina Plant Economics

Exhibit 3 CASE 3 Soda Ash Plant Economics

-III.13-

-III.14-

-III.15- 
Appendix 3

TABLE OF CONTENTS

\begin{tabular}{|c|c|}
\hline & Page \\
\hline $\begin{array}{l}\text { INTRODUCTION } \\
\text { Methods and Market Prices }\end{array}$ & $\begin{array}{l}-I .1- \\
-I .4-\end{array}$ \\
\hline $\begin{array}{l}\text { SUMMARY. AND CONCLUSIONS } \\
\text { Summary } \\
\text { Alumina } \\
\text { Soda Ash }\end{array}$ & $\begin{array}{l}-I I .1- \\
\text {-II.1- } \\
\text {-II.1- } \\
\text {-II.3- }\end{array}$ \\
\hline $\begin{array}{l}\text { MAJOR MARKETS FOR OIL SHALE MINERALS } \\
\text { A. Assumptions } \\
\text { B. World Trade Patterns } \\
\text { 1. Demographic and Economic Factors in Markets } \\
\text { 2. World Trade in Alumina and Sodium Oxide } \\
\text { Related Chemicals } \\
\text { History and Development } \\
\text { Trade in General Chemicals and Soda Ash } \\
\text { World Alumina Trade } \\
\text { World Alumina Production } \\
\text { World Caustic Soda Production } \\
\text { Alumina and Sodium Oxide End Uses and Economics } \\
\text { 1. Alumina } \\
\text { Production Raw Materials } \\
\text { Bayer Process for Alumina Production } \\
\text { Markets } \\
\text { World Supply } \\
\text { U.S. Alumina Supply Demand and Price History } \\
\text { Other End Uses of Alumina } \\
\text { Competitive Materials } \\
\text { New Uses for Alumina } \\
\text { Primary Aluminum Markets } \\
\text { 2. Major Sodium Oxide Commodities } \\
\text { Background } \\
\text { Soda Ash Production Capacity and Processes } \\
\text { End Uses of Soda Ash } \\
\text { Glass } \\
\text { Chemicals } \\
\text { Silicates } \\
\text { Chromates } \\
\text { Sodium Bicarbonate } \\
\text { Other Chemical Uses } \\
\text { New Chemical Uses } \\
\text { Pulp and Paper }\end{array}$ & 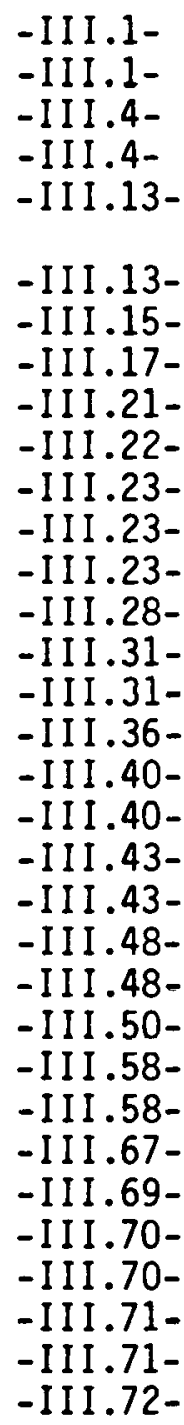 \\
\hline
\end{tabular}




\section{Appendix 3}

TABLE OF CONTENTS

(Continued)

Textile Uses

$-111.73-$

Soap and Glycerine

Rayon

Competitive Products

-III.73-

-III.73-

Caustic Soda Supply

-III.74-

Nahcolite

Semi-Finished Ash Markets

-III.78-

$-111.87-$

Economics and Logistics

-III.89-

Discussion

-III.90-

-III.90-

INTERPRODUCT COMPETITION AND TRADE IMPACT UPON SODA ASH

AND ALUMINA MARKETS

A. Interproduct Competition

B. Manufacturing Economics

Chemicals

Pulp and Paper

C. Caustic Substitution

D. Foreign Trade Imbalances

E. Alumina

F. Oil Shale Summary

-IV.1-

- IV.1-

- IV.5-

- IV.8-

- IV. $8-$

-IV.8-

-IV.9-

-IV.9-

-IV.9-

PROJECTIONS

Alumina

$-V .1-$

$-V .1-$

Soda Ash

$-V .7-$ 


\section{APPENDIX 1}

PROCESS DEVELOPMENT AND COSTING 
CHAPTER 1

\subsection{INTRODUCTION: OBJECTIVES AND SCOPE}

\section{Study Overview}

The objective of the study is to estimate the capital and operating costs of an oil shale/mineral co-products recovery facility to determine whether the production of shale mineral co-products (nahcolite, alumina and soda ash) can improve the economics of shale oil production. The full costs of the shale oil production and the marginal costs of separating and upgrading the nahcolite and converting the dawsonite ${ }^{l}$ to alumina and soda ash are determined.

As a necessary consequence of the study, the designs of an alumina/soda ash recovery (ALSAR) plant, and a nahcolite recovery unit were developed from a conceptual process engineering standpoint. The design of these facilities was made necessary by the fact that no detailed commercial-scale enqineering plans existed in the public domain, and an exhaustive equipment duty and equipment cost data-base was required for the execution of the downstream cost-engineering, economic, and financial analyses. A thorough description of the recovery processes, including flowdiagrams, mass and energy balances and pertinent chemical data is given in the report.

${ }^{1}$ Dawsonite and residual nahcolite are components of the net production of soda ash (dense). 


\section{Methodology}

A total of five (5) cases are examined which: (1) reflect the potential variations of the identified saline zone resource and; (2) consider modular and multi-modular commercial-scale production of shale oil at the approximate output levels of 15,000 barrels per day (BPD) and 50,000 BPD, respectively. The cases are defined by combining "rich" and "lean" shale grades (Fischer assay) with "rich" and "lean" mineral content (nahcolite and dawsonite weight percent) for the two plant sizes under consideration.

The resource characteristics for rich and lean Fischer assay and variable mineral content are defined in Exhibit 2-1. These definitions are based on a detailed review of core-sample data in the literature (Beard, Tait, and Smith, 1974; Hite and Dyni, 1967; Dyni, Beck and Mountjoy, 1971; Farris, 1978; Smith and Milton, 1966; Smith, Thomas and Trudell, 1968). Average mineral contents for saline zone shale in the northern Piceance Basin of colorado were calculated from the data, and the probable maximum and minimum values of mineral content were selected for the five cases examined.

On the basis of the resource data for each of the five (5) cases, a shale oil/mineral co-products facility is designed, and detailed cost-engineering and economic analyses are performed. The total facility includes an underground mining operation (room and pillar) and surface facilities for the production of shale oil and mineral co-products. Under each case, the mining operations and shale oil/mineral co-products facilities are designed according to the following analytical constraints:

(1) Facilities for shale oil production consist of an integral number of equally-sized retort modules $(20,000$ TPD) operating at process design throughput capacity. 
(2) The number of operating retort modules is determined by the required shale oil production level and grade of shale for each case. Cases (2), (4) and (5) are multiple-module cases with shale oil production levels of 45,000 - 54,000 BPD.

(3) Raw material production and handling facilities (mining operations, crushing and leaching facilities, and shale disposal) are designed and sized on the basis of design constraints (1) and (2) above.

(4) Mineral co-product facilities, (nahcolite recovery unit, and the alumina and soda ash recovery plant, or ALSAR plant) are designed and sized on the basis of the total flow-through of material defined by the above constraints for the production of shale oil.

The strategy thus adopted constrains the subsequent engineering and economic analyses of the mineral co-products to a "production limited" basis, as defined by the net production of shale oil. This methodology is cunsislent with the "co-product" assumption for the production of nahcolite, alumina and soda ash, and provides a discriminator for determining the economics of marginal capital investment and operating dollars for mineral co-product processing.

The major plant sections of the total shale oil/mineral coproducts facility are listed in Exhibit 2-4. Under each of the five cases of resource type and plant output (Exhibit 2-1), the individual plant sections displayed in Exhibit 2-4 are characterized by: (1) process flow diagrams; (2) mass and energy balances; and (3) equipment duty, labor and material-quantity calculations. Process flows and mass balances are calculated from detailed chemical processing data available in the literature. The process configuration assumed is highly conceptual in nature and is employed in the generation of cost and production data. On the basis of the material 
balances and equipment duty calculations, the total process equipment inventory for each plant section under each of the five study cases is determined. The equipment inventories enable cost-engineering "study estimates" to be prepared from detailed equipment capacitycost relationships available in the literature (Popper 1970, Peters 1958, Herkimer 1958, Dryden, et. al, 1966, Zimmerman 1970).

The estimation methods employed in the cost-engineering analysis involve several economic "scaling" relationships in the calculation of equipment capital and operating costs. A scaling-factor system is developed using a weighted-cost distribution method for the major plant sections. Factoring exponents for the individual plant sections listed in Exhibit 2-4 are calculated and used in "economy of scale" calculations. These scaling exponents yield important information regarding optimal resource characteristics-to-plant capital ratios, and are examined in the cost Engineering section of the report, (Chapter 3).

\section{Summary of Scope}

The full costs (capital and operating) of shalp oil production, and the marginal costs of mineral co-product production are detcrmined. The study is developed in two analytical phases: Engineering and Plant Process Design, and (2) Cost-Engineering/ Economic Analysis.

Examined in the study, are five (5) cases ranging over potential resource grades, and modular and multi-modular plant sizes. Under each of the five cases defined, a shale oil/mineral co-products facility is designed with the facility disaggregated into individual plant sections that are sized according to resource characteristics, and the raw material throughput volume required by the shale oil output level indicated in each case.

From the design analysis, an equipment inventory is determined, and a cost-engineering capital and operating cost analysis performed. 
An economic/financial analysis is initiated using the cost data from the cost-engineering phase and discounted cash flow (net present worth) analyses are performed.

The economic analyses determine the optimal resource-type, and processing plant size for maximizing marginal revenues from mineral co-product production. 
CHAPTER 2

2.0 ENGINEERING AND CONCEPTUAL PROCESS DESIGN ANALYSIS

General Scope

A shale oil/mineral co-products facility is designed for each of five (5) cases examined in the study. The cases considered range over the parameters of resource grade and modular and multi-. modular plant size as seen in Exhibit 2-I.

A block-flow diagram for the total plant facility is displayed in Exhibit 2-2, with the principal plant sections and operational groupings of the facility indicated. The throughput volumes indicated in this figure apply to the analysis of Case (3) which is defined to be a "base-case" since it is a pilot-size plant in the oil rich/ mineral rich shale resource. As shown in Exhibit 2-2, run-of-mine (ROM) ore is crushed to a minus eight-inch feed in the primary crushing stage prior to nahcolite recovery. Nahcolite is separated from the mineral-bearing shale on a continuous basis by crushing and photosorting techniques. An impure nahcolite product (containing raw shale fines) is produced and minus .25 inch shale fines arc ecalped from the retort feed and sent to shale disposal. The non-nahcolitic shale (approximately 80 percent of the nahcolite is recovered in the previous step) is discharged to the retorting unit for shale oil and off-gas production. The retorted shale exiting the retort unit is crushed to a fine consistency (minus 150 mesh) in preparation for alumina and soda ash recovery in the ALSAR* unit. After the leaching step in the ALSAR facility, the spent shale is transported to the hydraulic shale disposal unit for slurry backfill into the mine. Inactive mine panels will be backfilled

*AT,umina and Soda Ash Recovery 


\section{EXHIBIT $2-1$}

RESOURCE DEFINITION AND CASES EXAMINED

Plant Size

Lean Minerals, Rich Shale

Single Module

Case 1

- $0 \%$ Nahcolite

- 2\% Dawsonite

- 30 GPT $^{\dagger}$ Shale

Rich Minerals, Rich Shale

- 20\% Nahcolite

Case 3

- $12 \%$ Dawsonite

- 30 GPT Shale

Rich Minerals, Lean Shale

- $20 \%$ Nahcolite

Case 5
Multiple Modules

Case 2

Case 4

- 12\% Dawsonite

- 20 GPT shale

$$
{ }_{\text {GPT }}^{\dagger_{\text {G }}} \text { Gallon Per Ton (Fischer Assay). }
$$




\section{Exhibit 2-2}

\section{PROCESS FLOW DIAGRAM: CASE 3}

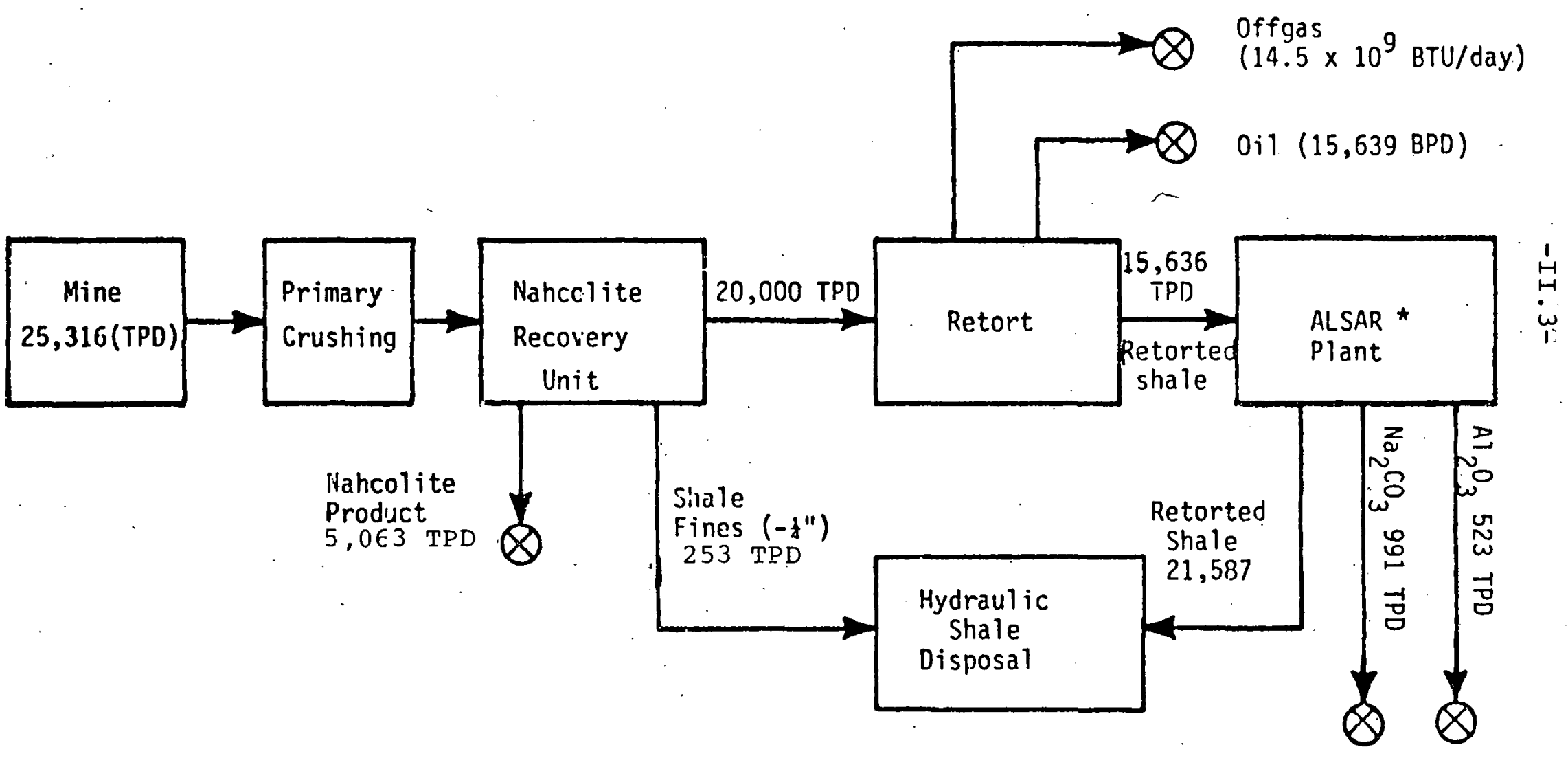

* ALSAR = Alumina Soda Ash Recovery 
with the finely crushed spent shale and raw shale fines. Decanted slur water is recycled to the slurry mixing facility.

Alumina and soda ash are recovered from the retorted shale leach liquor in the ALSAR unit. In the Case (3) analysis approximately 520 tons per day (TPD) of alumina and 990 TPD of dense soda ash are produced. Alumina is produced from the leach liquor by trihydrate precipitation and soda ash is crystallized in vacuum-effect evaporation units. The leach liquor is continuously recycled through the ALSAR plant with a plant process water make-up feed from external groundwater withdrawal wells.

In Exhibit 2-3, the design output capacities of the shale oil and mineral co-product plants are displayed for each of the defined cases. Cases (1) and (3) are single retort module facilities with a shale oil production level of 13,000 BPD to 15,000 BPD. Cases (2), (4) and (5) are multiple-module facilities with a shale oil output near $50,000 \mathrm{BPD}$.

The shale oil output in each of the plant cases is determined by the hydrocarbon grane ${ }^{l}$ of the ohale resuurce. 'l'he number of retort modules in the multiple-module cases (Cases (2), (4) and (5)) is determined by the resource grade and a required shale oil output of near 50,000 BPD. Mine operation and output, crushing and materials handling facilities, and mineral co-product processing facilities are designed, sized, and costed on the basis of the total material flow-through required for the production of shale oil. Therefore, it is assumed that: (1) all retort module(s) operate at full design capacity, and; (2) the amount of retorted material and the mineral content of the resource determine the size of the mineral co-product processing facilities.

${ }^{1}$ Fischer Assay, GPT (gallons per short-ton) 


\section{Exhibit 2-3}

\section{PRODUCT SLATES FOR THE FIVE CASES}

\begin{tabular}{|c|c|c|c|}
\hline $\begin{array}{l}\text { Raw Material } \\
\text { Lean Minerals } \\
\text { Rich Shale } \\
\therefore\end{array}$ & $\begin{array}{l}\text { Case } 1 \\
\text { Shale: } 21,053 \text { TPD } \\
\text { 0il: } 13,571 \text { BPD } \\
\text { Nahcolite: -- } \\
\text { Alumina: } 75 \text { TPD } \\
\text { Soda ash: } 78 \text { TPD } \\
\text { (1 retort module) }\end{array}$ & $\begin{array}{l}\text { Case } 2 \\
\text { Shale: } 84,212 \text { TPD } \\
\text { Oil: } 54,284 \text { BPD } \\
\text { Nahcolite: }-- \\
\text { Alumina: } 300 \text { TPD } \\
\text { Soda ash: } 312 \text { TPD } \\
\quad \\
\text { (4 retort modules) }\end{array}$ & . \\
\hline $\begin{array}{l}\text { Rich Minerals } \\
\text { Rich Shale }\end{array}$ & $\begin{array}{l}\text { Case } 3 \\
\text { Shale: } 25,316 \text { TPD } \\
\text { 0il: } 15,639 \mathrm{BPD} \\
\text { Nahcolite: } 4,050 \text { TPD } \\
\text { Alumina: } 523 \text { TPD } \\
\text { Soda ash: } 991 \text { TPD } \\
\text { (1 retort module) }\end{array}$ & $\begin{array}{l}\text { Case } 4 \\
\text { Shale: } 75,948 \text { TPD } \\
\text { Oil: } 46,917 \text { BPD } \\
\text { Nahcolite: } 12,150 \text { TPD } \\
\text { Alumina: } 1,569 \text { TPD } \\
\text { Soda ash: } 2,973 \text { TPD } \\
\text { (3 retort modules) }\end{array}$ & \\
\hline $\begin{array}{l}\text { Rich Minerals } \\
\text { Lean Shale }\end{array}$ & Not analyzed & $\begin{array}{l}\text { Case } 5 \\
\text { Shale: } 126,582 \text { TPD } \\
0 \text { il: } 52,132 \text { BPD } \\
\text { Nahcolite: } 20,253 \text { TPD } \\
\text { Alumina: } 2,616 \text { TPD } \\
\text { Soda ash: } 4,956 \text { TPD } \\
\text { (5 retort modules) }\end{array}$ & \\
\hline
\end{tabular}


Exhibit 2-4

Major Plant Sections of a

Commercial Shale 0il/Mineral Co-Products Facility

Plant Section

Minino

Miine (Room and Pillar)

Primary Crushing

Conveying

Nahcolite Recovery Unit

Shale Stockpile

Secondary Crushing

Nancolite Recovery (screening and photosórting)

Retort and 0 il Recovery

Retort and 0il Recovery

Gas Recovery

Syncrude Handling and Distribution

A.LSAR ${ }^{1}$ Plant Section

Retorted Shale Crushing

Crushed Shale Leaching

Aluminum Trihydrate Precipitation

Alumina Calcination

Soda Ash Crystallization

Soda Ash Dehydration

Product Hand? ing \& Distribution

Process $\mathrm{H}_{2} \mathrm{O}$ Treatment

Water Treatment

Wells/Mine Dewatering

Underground Hydraulic Shäle Disposal

Slurry Pumping Unit

De-Sliming/Recirculation

General Plant Facilities

Utilities

Administration buildings

Warehouses, etc.
Function/Output

ROM shale

-8 " shale

Storage

-3 " shale

Nancolite products

(Baghouse/stack

scrubber material)

Raw shale oil

Low BTU gas

Storage - Loading

-150 mesh

Soluable extraction

$\mathrm{A})(\mathrm{OH})_{3}$

Alumina $\left(\mathrm{Al}_{2} \mathrm{O}_{3}\right)$

$\mathrm{Na}_{2} \mathrm{CO}_{3} \cdot \mathrm{H}_{2} \mathrm{O}$

$\mathrm{Na}_{2} \mathrm{CO}_{3}$ (Dense)

Storage - Loading

Process water cleanup

Water Supply

Slurry transportation

Stabilization/Recovery

General Support

and Services 
In the analysis of conceptual process design, Case (3). is defined to be the "fundamental" case for basic engineering and design calculations. This case considers a single-module facility with an available shale resource containing the maximum hydrocarbon and mineral content assumed in the study. Calculations for the individual plant sections displayed in Exhibit 2-4 pertain to the resource assumptions of case (3), and the mass and energy balances developed in this Chapter are related to the assumptions and fixed parameters of this case.

Designs for the individual plant sections of the remaining four (4) cases are scaled from the case (3) results. The scaling methodology employed utilizes the best available data from the literature, and accounts for "non-linear" effects in the engineering scaling process. Critical limiting factors in plant design scaling are accounted for in the extrapolation of process concepts: from the case (3) design scenario. An identical economic scaling procedure is employed in the cost-engineering analysis for the estimation of plant capital, installation labor, and operating costs (Chapter 3 ).

In this chapter, a detailed description of the plant sections and processes is given. Critical process criteria and assumptions are outlined, and calculations of material and energy flow are given for the case (3) analysis.

\subsection{MINING}

2.1.1 Description and Assumptions

Described in this section, are the critical design criteria and key assumptions used in the analysis of the mining operations for each of the five cases examined. A summary of these criteria 
and assumptions follows below:

- Co-Product Related Mining Factors

- Single level room and pillar mine in the saline shale zone.

- A uniform, flat-lying bed of oil shale with dawsonite and inter-bedded nahcolite nodules, with a mineable thickness of 60 feet.

- No selective mining of nahcolite beds is assumed.

- Conventional Mining Factors

- The mine is developed in large independent panels separated by barrier pillars. Panel dimensions are approximately 1,140 feet in width and 5,600 feet in length.

- Pillars are a minimum of 120 feet in lateral dimension and an overall extraction of $45 \%$ of the defined mining horizon is achieved.

- Gassy mining conditions are assumed for all mining cases. A seven panel-entry design is used in conjunction with a five main-entry system for panel access.

- Access to the mine is through parallel inclines possessing a maximum decline-angle of 15 degrees.

- Production panels are developed on a 2:1 ratio of production shifts to maintenance shift, respectively, in order to achieve an 85\% equipment availability standard.

As indicated above, the type of mining operation considered for all the cases under examination is a single-level room and pillar mine in the lower saline shale zone. The mining interval, approximately 2,000 ft. in depth, is assumed to be a uniform, nearly flatlying bed of oil shale containing nahcolite and dawsonite of the weight percentages stipulated by the resource definitions of each case. The mineable thickness of the development horizon is assumed 
to be approximately 60 feet in extent, and in the cases where nahcolite is present, the shale is assumed to be inter-bedded with nahcolite nodules ranging in size from a fraction of an inch, to a few feet in dimension.

The dawsonite occurs as fine crystals, approximately $5 \mu$ or less in size, and is evenly distributed through the shale marlstone matrix.

In none of the cases are nahcolite beds selectively mined. The production of nahcolite and dawsonite is assumed to be a byproduct of the mining operations. The occurence of minerals in the shale is assumed to not alter conventional room and pillar mining operations, with the exception of dust suppression techniques and hydraulic backfilling operations where slurry water must be carefully contained.

Control of water sources within the mine is essential to $\therefore$ mining operations in the saline shale zone. Evasion of mine pillars by the dissolution of solublè: mineral salts must be carefully considered in the integrated mining and slurry backfilling operations.

Two means of access to the proposed ore body were developed in this study; these are access by vertical shaft and inclined slope. Alternate analyses of the two ore transportation methods indicate that: (I) the high transport volumes of run-of-mine (ROM) ore in each of the cases examined, and; (2) the relatively extreme depth of the saline zone shale resource, are sufficiently compelling factors for the selection of the access incline (inclined slope) method over the shaft and skip-hoist ore haulage method. Therefore, for the purpose of the economic evaluation in this study, the inclined slope access methodology was selected and is the only type of mine acress discussed below, 'Access to the mining zone in 
all cases examined is assumed to be through parallel inclines approximately 12,000 feet in combined length, extending from the surface at a $10^{\circ}-15^{\circ}$ angle of dip. Access is from off-tract in all cases examined. Transportation of the ore is via twin conveyor systems of 36 or 60 inch width, depending on the total volume of ore required by each case.

A gassy mine classification has been assumed for the mining plans developed in this study. According to the code of Federal Regulations, Title 30 (CFR-30), Section 57.21-1, a mine shall be deemed gassy if:

A. The state in which the mine is located classified the mine as gassy, or;

B. Flammable gasses emanating from the ore body or to strata surrounding the ore body has been ignited in the mine, or;

C. A concentration of $0.25 \%$ or more, by air analysis of flammable gas emanating only from the ore body or the strata surrounding the ore body has been detected, not less than twelve (12) inches from the back, face, or ribs in any open workings, or;

D. The mine is connected to a gassy mine.

These regulations refer to gassy underground metal and nonmetal mines. The implications of a gassy mine classification in oil shale mining is significant from the following standpoints: (1) the removal of thousands of tons per day of shale is required, and these operations will require the utilization of the largest equipment available under a permissible classification, and (2) the costs of retrofitting an existing oil shale mine designed under anticipated non-gassy conditions, and subsequently declared gassy 
can range nearly two or three times the initial cost of the mine facility (Trent, 1979). Advanced planning for gassy mining conditions is almost imperative in deep oil shale mines, and is therefore assumed in the mine designs of the five cases examined.

The major design differences between non-gassy, and gassy underground mines are in the number of main-entries, panel-entries, and ventilation openings. The major operating differences are in the ventilation procedures, equipment inventory, and explosives employed. The significance of these points is that it is not possible at this time to operate permissible diesel engines of sufficient size to provide optimum equipment sizing. The implications of the gassy mine classification have been accounted for in the design of the mines examined in this study..

A basic room and pillar mining method is developed so that economic comparisons can be made for the tonnage requirements of the various cases examined. The proposed basic mining plan will produce oil shale from a 60 foot thick seam located approximately 2000 feet below the surface, with a reserve area of 6.25 square miles. All assumptions relating to the mining plan, equipment inventury and personnel required, are based on studies of mining operations under similar conditions, and the experience of the authors in gassy and non-gassy mining operations.

The mining scheme developed consists of a seven main-entry system through the center of the tract with five sub-main entries connecting the main system to the production panel. Each panel is 1,140 feet wide and approximately 5,600 feet long. A barrier pillar 400 feet in width separates the production panels and protects the mine complex in the event of panel roof failure. Mining operations proceed on a cyclic drill, blast, load, haul, and bolt system on two benches, each of 30 feet in height, respectively, with crosscuts of the same dimension on both benches. 
Pillars are a minimum of 120 feet in lateral dimension (along the mains) and mining is limited to an overall extraction of approximately 45 percent. The main entry quarter system has a total width of 1290 feet, and it extends the entire length of the $2.5 \mathrm{mile}$ section. The main entries are 30 feet wide by 30 feet high, and are separated by 180 foot square pillars.

\section{$\underline{2.1 .2 \quad \text { Mining Equipment }}$}

Mining equipment to be used will be that which is currently available "off-the-shelf". All calculations for the mining system are based on an 85 percent equipment availability. One maintenance shift for every two production shifts will be required to maintain the 85 percent availability. To operate on a two shifts production, one shift maintenance basis, it will be necessary to have a third production panel available for every two production panels. In Cases (1) and (3), (Exhibit 2-3), one panel is required for production, and a second panel will be required for maintenance in third shift production. Mining operations in Cases (2) and (4) require three production panels which will allow two shifts of production, and one shift of maintenance in each panel. In the large tonnage mining operation of Case (5), five panels are necessary for the requisite ratio of production to maintenance time in each panel.

The mining equipment inventory for Case (3) is given in Exhibit 2-5. All mobile and/or diesel powered equipment utilized is classified as permissible for use in a gassy mine environment. The major impact of this classification is the limitation of equipment size and brake horsepower used in the mine. The equipment inventory for the mining operations will consist of 6 cubic yard FEL's, 25 ton in-dump hauling trucks, hydraulic drill jumbos for drilling the upper bench face, and diesel pneumatic air track drills for drilling the bench. Roof bolting equipment will consist of single boom combination bolters and scalers. Explosives will be 
Exhibit 2-5

MINING EQUIPMENT INVENTORY

IN-PANEL PRODUCTION EQUIPMENT

Case (3)

Item/Type

Number

Hydraulic Drill Jumbos/2-Boom

4

Drill/Air Track

2

FEL/6-yd ${ }^{3}$

4

Bulldozers

6

Trucks/25-ton

17

Bolter - scalers

3

Explosives Trucks

2

Breaker + Feeders

4

Belt Conveyors (36")

$14,000 \mathrm{ft}$.

Apron Feeders

4

Transfer Conveyors

$900 \mathrm{Et}$.

Main Conveyors (60")

$9,000 \mathrm{ft}$.

Jeeps

8

Fire, water, Fuel Trucks

3

Personnel Carriers

2

support (Phones, Tiights, etc.) Systems -

Main Ventilation Fans

2

Face Fans

20

Curtains, Brattices, etc.

Utility/Power systems 
loaded into the face with a diesel power - rideover pneumatic loading machine. Road maintenance will be served with diesel powered graders and bulldozers, while supplies are conveyed to the mine face with diesel powered supply jeeps. As can be noted, all of the primary pieces of equipment listed above are diesel powered to comply with the gassy-mine regulation of permissibility.

Ore transport will be provided by a 25-ton truck from the face area to a breaker-feeder that is located in the center entry of the panel-entry system. The breaker feeder will reduce the size of the ore to approximately minus 18 inches for transportation on the panel belt conveyor which is linked to the large main-entry conveyor for transport of the ore to the surface.

Ventilation in the mine will be provided by fans approved for gassy mines, and ventilation at the working faces will be provided by the conventional auxiliary fan and flexible vent tubing system. Under extremely gassy circumstances, auxiliary fans may be replaced with a brattice cloth system similar to that used in coal mining operations.

\section{1 .3 Mine Water}

The presence of mine water under the conditions described above would, in almost all cases, present insurmountable obstacles to the mining of a multimineral bed of oil shale. With regard to water from the natural aquifer system, a saline zone oil shale mining operation is less at risk than a similar mining system in the upper shale zones (Mahogany zone). Generally speaking, the saline zone is quite dry (thereby accounting for the presence of the soluble salts), however, disruption of the aquifers may occur during mine and mine access development. If water is encountered during the development phase, it is necessary to develop a seal and collection system to prevent water from entering the ore zone. 
Recent experience in the trona fields of Wyoming has shown that large inflows of water not only deteriorate support pillars, but also make travel in vehicles with rubber tires difficult.

The water sources of primary concern to water invasion of the mine originate in the hydraulic slurry disposal of the processed shale, and water used in dust supression. special precautions must be taken to ensure the proper drainage and collection of water decanted in the slurry disposal process. Several measures have been adopted:

(1) Slight dips of the ore body are utilized in conjunction with drainage passages to keep water away from active production panels, and;

(2) Large barrier pillars (400 feet) separate the panels and prevent water flow and migration from the disposal panels to the production panels.

In dust supression operations, it will be necessary to closely regulate the amounts of water used, or an alternative means of dust supression such as steam may be employed. The steam technique has been employed successfully in the trona mining operations of Wyoming, however, if because of the higher ambient moisture content, the ore begins to "concretize" or set-up, it may be necessary to develop a set of ore bins where the ore is continually moving prior to transport to the surface.

The protective measures discussed above have been integrated into the mine designs for all five cases under examination.

\subsubsection{Mine Development and Operation}

Development of the mine will proceed on a two shifts per day, five days per week basis for Cases (2), (4) and (5), and on a one 
shift per day basis for Cases (1) and (3). Production will be accomplished on a three, shifts per day, 364 days per year basis for all cases.

As discussed in \$2.1.2, one maintenance shift for every two production shifts per panel is incorporated in the design of the mine in all cases. The defined phasing of production and maintenance operations guarantees an 85 percent equipment availability and substantially reduces the required back-up equipment inventory for panel and face equipment.

Mining operations proceed on a cyclic drill, blast, load, haul, and bolt system on two benches of 30 feet in height. Blasted rock from the upper bench is swept to the lower bench where it is mucked with front-end-loading (FEL) equipment. Ore is conveyed from the face area by 25-ton trucks to breaker-feeders located in the center entry of the panel-entry system.

The deployment and support of the sub-surface conveyor system is the responsibility of the mine development crew. A $2: 3$ shift-. ratio of transportation support operations to development fontage production is assumed for the development crew. Production personnel are dedicated entirely to panel and production face operations. 


\subsection{CONVEYING, PRIMARY CRUSHING AND STORAGE}

The ore transport system within active mine panels consists of mucking the ore with FEL equipment and conveying the loaded ore by 25-ton trucks to impact crushers centrally located within the panels. The broken material (minus $18 \mathrm{inch}$ ) is fed to small panel conveyors (36-inch) that discharge their burden to large mainentry conveyors (60-inch). The main-entry conveyors transport the ore to the surface for primary crushing.

The primary crushing unit consists of dual-gang, heavy-duty single roll crushers (48 by 72-inches), screens, hoppers, and a coarse ore stockpile facility. The primary crusher reduces the ore from minus 18 inches (sized in the impact feeders) to minus 8 inches for secondary crushing and nahcolite recovery.

A covered coarse ore stockpile consisting of a traveling stacker unit, reclaiming conveyor, and transfer unit follows the primary crushing stage. The total surface conveyor and handling system is covered for protection of the ore (soluble minerals) and dist control. The surge capacity of the stockpile is assumed to be a 30-day supply of ore to the secondary crusher and nahcolite recovery unit.

Environmental control equipment consists of blowers, cyclones, and baghouses for fugitive dust control. Wet suppression of dust is not employed within the system because of the soluble mineral content of the ore. 


\subsubsection{Description and Assumptions}

Nahcolite nodules are assumed to be inter-bedded with the shale in nodules ranging in dimension from a fraction of an inch to a few feet in diameter. The nahcolite is assumed to occur in the shale beds in two varieties: (1) microcrystalline structure, and (2) a crystal "mush" deposition. Microcrystalline beds are scattered vertically through the saline-zone shale horizons in discrete nodules of dimension stated above. The crystal "mush" occurrence is intimately mixed with the shale matrix with this type of occurrence laterally deposited through the shale beds in general. No selective mining of nahcolite lenses or beds is assumed under the cases examined in this study ( $\$ 2.1 .1$ ).

The nahcolite recovery unit separates a nahcolite product from the shale prior to the retorting step as indicated in Exhibit 2-2. Several methods have been developed and patented for the separation of nahcolite from run-of-mine ore. Weichman (1974, U.S. Patent), has developed a crushing and screening methol that produces a relatively pure nahcolite product. Characteristic to this method are the different material properties of the shale ore and mineral constituents. The friability of the nahcolite is used in order to selectively collect this mineral in the "fines" by mechanical screening. Wyslouzil (1976, U.S. Patent), and Rhys (19.76, U.S. Patent), have developed photosorting techniques for the separation of nahcolite from ore (shale). These techniques largely rely on lightly calcining the nahcolite ("natural" sodium bi-carbonate) in order to produce color differences between the mineral and host material. The differentiation in color (or shades) may be used as a basis for photosorting recovery of the mineral. In addition to these "dry" separation processes, Rosar, et al (1974, U.S. Patent) obtained a patent for a froth flotation method of nahcolite separation from nahcolite containing ores. 
The conceptual process selected for analysis in the present study embodies the crushing-screening and photosorting methods discussed above. Exhibit 2-6 is a flow diagram for the process selected and is due to Miller, (1979, modified). It is assumed that approximately 80 percent of the nahcolite is recovered in this unit which produces a nahcolite product of approximately 80 percent purity. ( 20 percent shale fines dilution).

\subsubsection{Nahcolite Recovery Unit: Equipment}

The flow diagram of Exhibit 2-6 displays the various components of the facility for the case (3) analysis. Secondary crushing is contained within the unit and is accomplished through a triplegang of gyratory crushers (36-inch) and twin single-screen decks. $\because$ A double-deck screen separates the material for initial photosorting = or crushing separation. In the photosorting section a rotary-type kiln is used for the calcination of the nahcolite. Separated raw $\therefore$ shale is charged to the retort, and the highly nahcolitic shale is $=$ discharged to a tertiary crushing stage for further beneficiation

Nahcolite is more friable than shale and can be recovered by selertive srreening of the fines produced during the tertiary crushing stage. Reversible impact crushers are selected in order to produce the required fines material.

The nahcolite product (approximately 80 percent in purity) is separated into two product types as indicated in Exhibit 2-6. Raw shale fines, (minus .25-inch material), are screened from the retort feed and are transported to the disposal system or continue in the nahcolite product stream as an impurity. The circular gratetype retorts utilized in the design of the oil shale facility are unable to accept the fines material for processing. It is not assumed that this material is processed in fines-type retorts in any of the cases studied. 
Exhibit 2-6

NAHCOLITE RECOVERY UNIT CASE 3

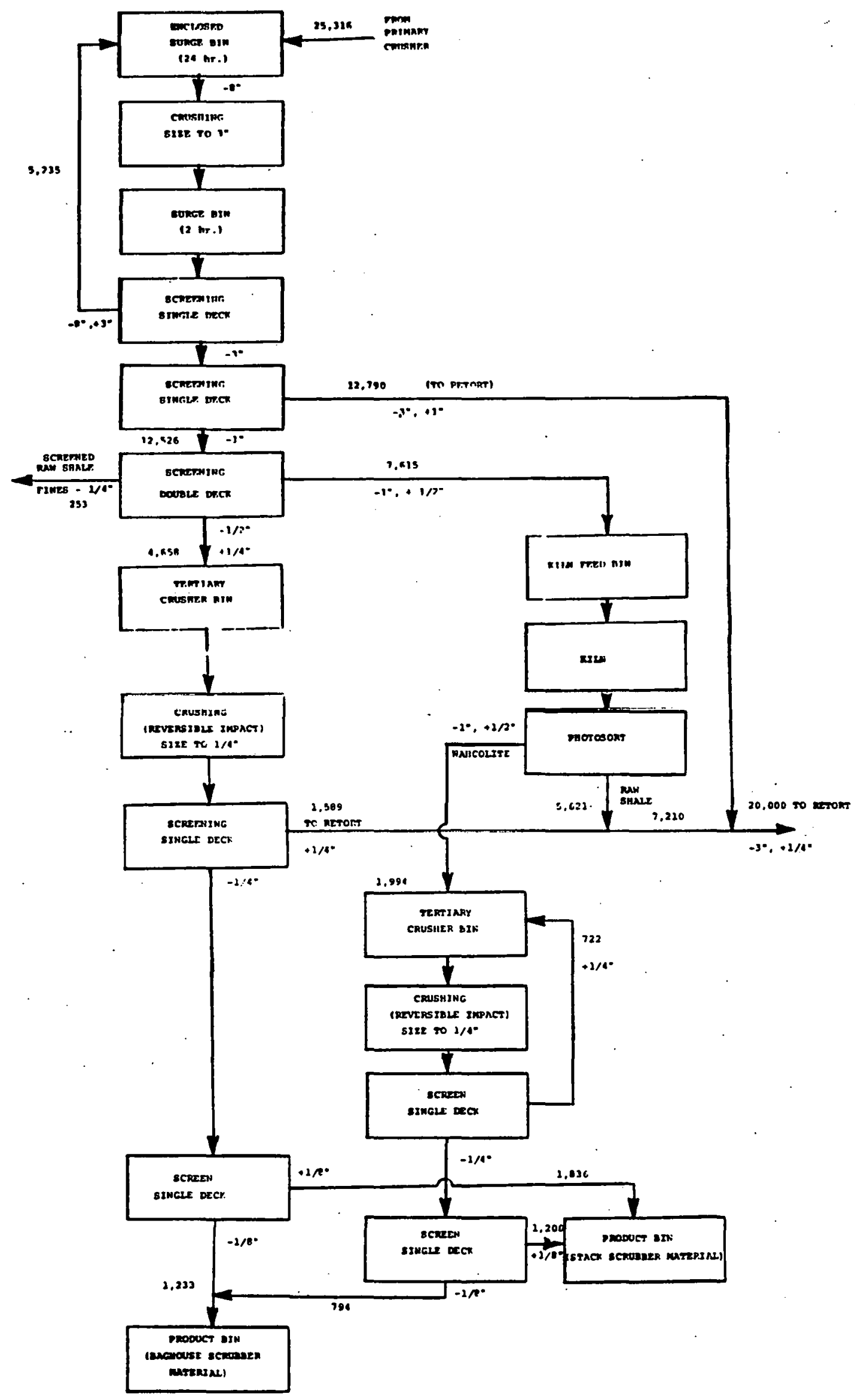


Exhibit 2-6 displays the mass balance of the nahcolite recovery unit for the Case (3) analysis. A total of 1,266 TPD of shale fines are generated ( 5 percent), with 253 TPD sent to disposal, and 1,013 TPD entrained in the nahcolite product stream. A separation phase angle of $.245\left(14^{\circ}\right)$ is attained in the primary fines screening stage. A maximum theoretical phase angle of $1.05\left(60^{\circ}\right)$ would minimize the raw shale impurity of the nahcolite product under the screening sizes indicated, without: (1) reducing total product volume, or (2) redesigning the unit for total photosorting recovery.

In the case (3) analysis, the electrical power requirement for the crushers, conveyors, feeders, and blowers is calculated to be $2.36 \mathrm{Mw}$. Fuel gas requirements from the retort is $1.28 \times 10^{9}$ BTU/day for the (partial) calcination kiln prior to photosorting.

\subsubsection{Nahcolite Properties and Processes}

Nahcolite not recovered in the nahcolite recovery unit is either collected in the shale fines (minus.25-inch) or is contained in the raw shale feed transported to the retorting module. Nahcolite. processed in the retort (under proper temperature conditions) is recovered in the ALSAR unit $(\$ 2.5)$ as soda ash. The nahcolite is calcined in the retort according to the following reaction:

$$
2 \mathrm{NaHCO}_{3} \rightarrow \mathrm{Na}_{2} \mathrm{CO}_{3}+\mathrm{H}_{2} \mathrm{O}+\mathrm{CO}_{2}
$$

Approximately 45 percent of the total soda ash output of the ALSAR unit results from the conversion of the residual nahcolite not recovered prior to the retorting stage. The balance of the net soda ash production is derived from the sodium-aluminate mineral, dawsonite. 
Weichman, et al. (1976, U.S. Patent) discuss a method of reduction of sulfur and nitrogen in liquid or gaseous hydrocarbons using nahcolite. A contact process between the nahcolite and hydrocarbon, and the removal of a resulting solid containing the desired hydrocarbon impurities is described.

Similarly, dry alkalis (including nahcolite) may be used to remove sulfur dioxide from flue gasses, (Knight, J.H. 1977, U.S. Patent). Tassicker, (1976), discusses the use of nahcolite in fluegas desulfurization, nitrous oxide removal, and particulate control. A typical desulfurization reaction for nahcolite is:

$$
2 \mathrm{NaHCO}_{3}+\mathrm{SO}_{2}+\frac{1}{2} \mathrm{O}_{2} \rightarrow \mathrm{Na}_{2} \mathrm{SO}_{4}+\mathrm{H}_{2} \mathrm{O}+2 \mathrm{CO}_{2}
$$

Sodium sulfate can be recovered from the process for chemical re-sale or can be rendered insoluble for landfill disposal (Dulin, et al., 1975).

A further end-use of nahcolite involves converting the recovered nahcolite product to soda ash in a leaching/cryst.al 1 i ration/dehydration process scheme related to natural soda ash production from trona. A report by the U.S. Bureau of Mines (Staff, 1972, Option I) discusses a proposed process for soda ash conversion.

Farris, et al. (1978, I) presents a process for the production of dense soda ash from recovered nahcolite. The process involves: (1) nahcolite calcination, (2) leaching, (3) crystallization, and (4) product dehydration. A filtered sodium carbonate-pregnant solution is crystallized to form a monohydrate product which is dehydrated to produce dense soda ash. 
In the cases examined in this study, the recovered nahcolite is not dedicated to any on-site utilization as discussed above. The nahcolite product is stored in covered storage bins for transport from the shale oil/mineral co-products facility.

2.4 RETORTING/OIL AND GAS RECOVERY

2.4.1 Description and Assumptions

The basic retort module utilized in the design of the shale oil facilities in each of the five cases examined is a circular horizontal grate-type retort with a processing capacity of 20,000 TPD. ${ }^{1}$

This retort type is selected on the basis of the following factors:

(1) Control of retorting temperatures $\left(450^{\circ}-600^{\circ} \mathrm{C}\right)$ is critical to retorted shale leaching and mineral co-product processing.

(2) Temperature and residence-time can be precisely controlled in a circular grate retort.

(3) Positive material movement of the horizontal grate and segregation of feed size prevents clinkering and material flow problems.

The temperature in the retort must be carefully controlled for subsequent retorted shale leaching and mineral co-product production. If temperatures exceed $600^{\circ} \mathrm{C}$ in the retort, the

$I_{\text {Tons of raw shale per day }}$ 
sodium carbonate generated by the decomposition reactions of nahcolite and dawsonite will react with other shale matrix minerals creating a flux material for glass formation (Smith, et al., 1975). The formation of silica-glass constituents severely reduces the recovery of alumina and soda ash in the ALSAR unit.

The commercial design configuration considered in this study is a circular grate retort with a direct-heated mode of operation. Exhibit 2-7 shows the direct heated mode where a portion of the retort gas phase is combusted and mixed with pre-heated recycle gas from the "cooling" zone as indicated. Hood inlet temperatures are $600-800^{\circ} \mathrm{C}$ as required.

In the direct mode, a surplus of retort gas is produced. This gas, diluted by nitrogen, has a heating value of approximately 90-110 BTU per cubic foot. In the Case (3) analysis, the data indicate (Sandell, et al., U.S. Department of Interior, 1979, Melcher, et al., 1979), that $14.5 \times 10^{9}$ BTU per day of 90 BTU per cubic foot offgas is produced by a single retort module. In \$2.5.4, a detailed energy balance is given and indicates that the retort offgas will be sufficient to meet the processing requirements of the mineral co-product facilities.

Methods of increasing thermal efficiency, throughput rate per square foot of active area, and gas circulation for circular grate retorts have been developed (Knight 1978; and U.S. Patent, 1978). Two modes of heat transfer are active in the grate bed: ( 1 ) heat transfer through the bed by forced convection and conduction, and (2) intra-particle heat transfer (Shen, et al., 1965). The precominate variables in these heat transfer mechanisms are: energy delivery rate controlled by temperature and gas flow rate, (2) particle size distribution and bed height, and (3) residence time. 
Exhibit 2-7

\section{CIRCULAR GRATE RETORT-DIRECT-HEATED MODE}

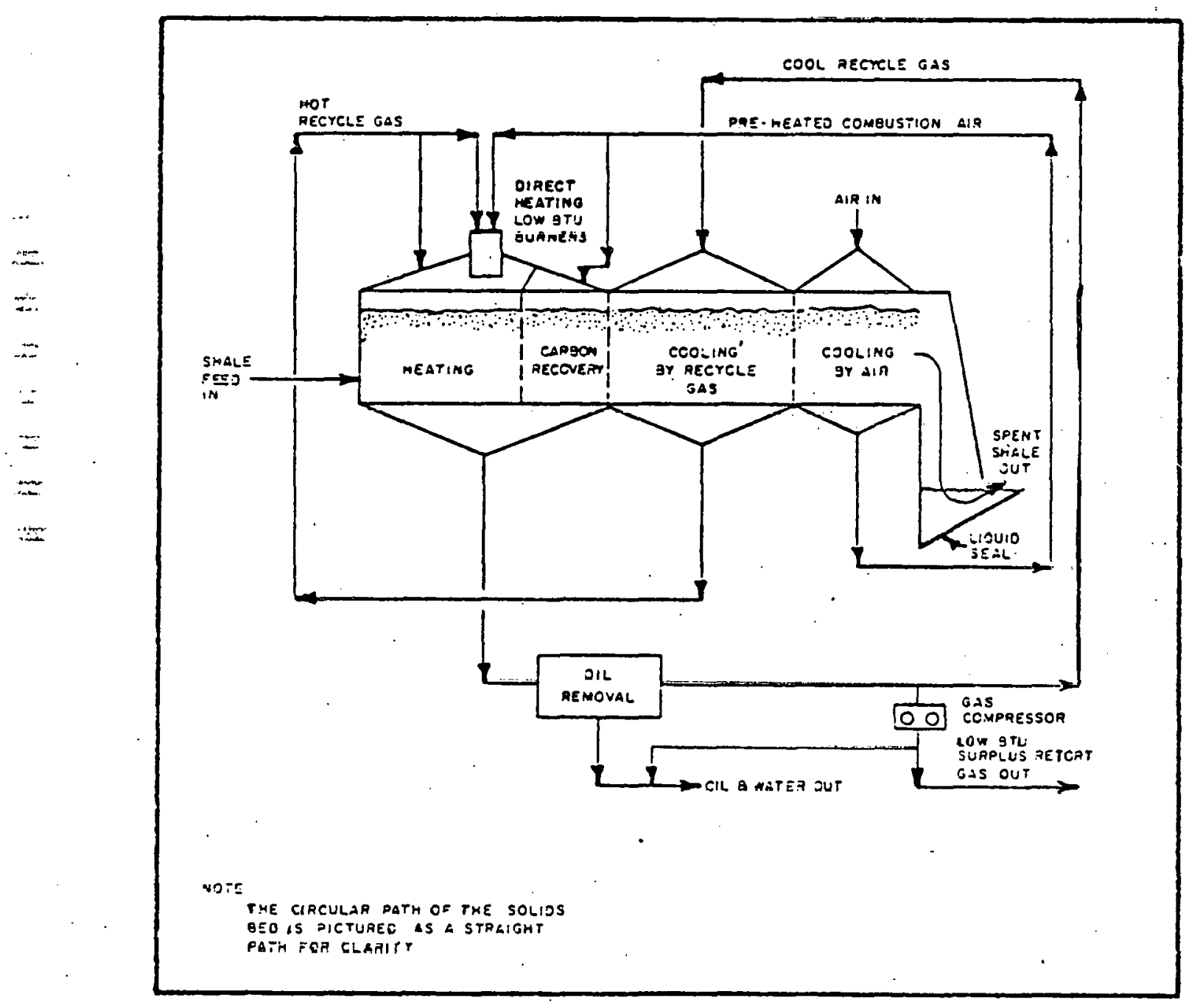


A distinct advantage of the circular.grate retort system is that temperature and gas flow rates can be adjusted independently and the energy delivery rate to each processing zone is highly controlled. Residence time and temperature are critical factors to retorted shale leaching and mineral co-product production.

\subsubsection{Retorting Yields}

The resource characteristics of Case (3) imply that a yield of 15,639 BPD of shale oil (95 percent process efficiency) is produced from the single retort module. The run-of-mine grade of shale in this Case is 30 GPT prior to nahcolite removal. Post nahcolite recovery, the grade of shale entering the retort module is 34.6 GPT at a rate of $20,000 \mathrm{TPD}$ per module. Approximately $14.5 \times 10^{9}$ BTU per day is produced as low-BTU retort offgas and provides the fuel requirements for process heat in the ALSAR unit. The heating value (HHV) of the gas is 90 BTU per cubic foot. A portion of the required process heat for the ALSAR unit is derived as sensible heat by thermal exchange with the retort recycle gas. An energy balance for the combined shale oil/mineral co-product facility is given in $\$ 2.5 .4$ for the Case (3) analysis.

The circular grate utilized in the plant design is equipped with a water seal between the retort covering hood and the stationary windboxes underneath the rotating grate. This water seal - a distinct improvement over conventional circular grate kilns possesses several advantages: (1) process gas is sealed into the retort, (2) air is sealed out, and (3) unrestrained thermal expansion of structural members is allowed thus eliminating leaks from the retorting vessel.

The oil removal system consists of a water-spray conditioner and an electrostatic precipitator. Oil mist exiting the retort unit is contacted by the water sprays where: (1) the gas/vapor 
phase is cooled to saturation temperature, (2) sulfur compounds are scrubbed from the hydrocarbons, and (3) the oil mist is "conditioned" for electrostatic recovery. The precipitator removes the oil and water droplets from the gaseous phase by electrostatic charging and precipitation onto a collector imbedded in a large electric field (capacitor plates).

Process gas separated in the oil removal system is either recycled to the retort "cooling" zone for preheating prior to combustion, or it is compressed and used as process fuel gas in the ALSAR unit and external process boilers.

In Case (3) 15,636 TPD of retorted shale is discharged via a ... mechanical air seal to the ALSAR unit for mineral co-product recovery. During retorting the mineral values undergo chemical decomposition s as discussed in the following section.

\section{$\therefore 2.4 .3$ Mineral Carbonate Decomposition}

Nahcolite and dawsonite rontained in the retort shale feed zundergo decomposition reactions during the retorting (hydrocarbon recovery) stage. The thermal history of the mineral/shale matrix through the retorting process is critical to the recovery of the mineral co-products. Solubility of the principal aluminum values from dawsonite is severely impaired by the formation of glass-silica compounds if the retorting temperature exceeds $600^{\circ} \mathrm{C}$. (Smith, et al., 1975). Sodium carbonate generated from the decomposition of the carbonates acts as a flux in high retorting temperature regimes $\left(+600^{\circ} \mathrm{C}\right)$ and reacts with other shale minerals (i.e., Analcite: $\mathrm{Na} \mathrm{Al} \mathrm{Si}_{2} \mathrm{O}_{6} \cdot 2 \mathrm{H}_{2} \mathrm{O}$ to form encapsulating glass compounds, thereby severely reducing the net solubility of the dawsonitic aluminum values. 
Approximately 15-20 percent of the nahcolite present in the runof-mine ore is unrecovered in the nahcolite recovery unit. This nahcolite is charged to the retort and is thermally decomposed during hydrocarbon recovery. Nahcolite, on heating to $270^{\circ} \mathrm{C}$, decomposes into soda ash, water vapor, and carbon dioxide according to the following reaction:

$$
\begin{gathered}
2 \mathrm{NaHCO}_{3} \rightarrow \mathrm{Na}_{2} \mathrm{CO}_{3}+\mathrm{H}_{2} \mathrm{O}+\mathrm{CO}_{2} \\
27.0^{\circ} \mathrm{C}
\end{gathered}
$$

Dawsonite ( $\mathrm{NaAl}(\mathrm{OH})_{2} \mathrm{CO}_{3}$ ), intimately mixed with the shale in

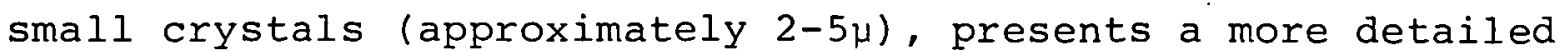
decomposition pathway than shale-associated nahcolite. By differential thermal analysis (DTA) and scanning calorimetry, dawsonite has been shown to exhibit two distinct and large endothermic reactions in the $300-400^{\circ} \mathrm{C}$ range (National Academy of Science, 1970). Two different structural forms of dawsonite are believed to be present in the shale and two separate reaction mechanisms have been proposed for the carbonate bi-forms Dawsonite I and II.

Dawsonite I is a bicarbonate form that decomposes in the retort environment according to the following reaction:

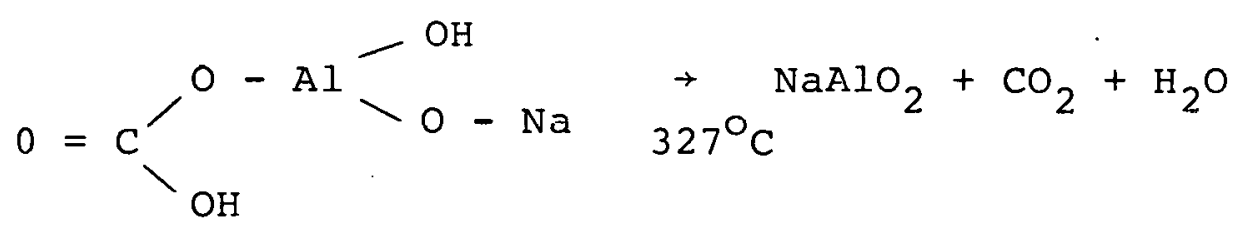

(Dawsonite I)

The sodium aluminate produced is highly soluble in the leaching section of the ALSAR unit under a light caustic leach. Dawsonite II decomposes to yield an insoluble aluminum oxide (chi-form alumina) and sodium carbonate (soda ash) according to the following reaction: 


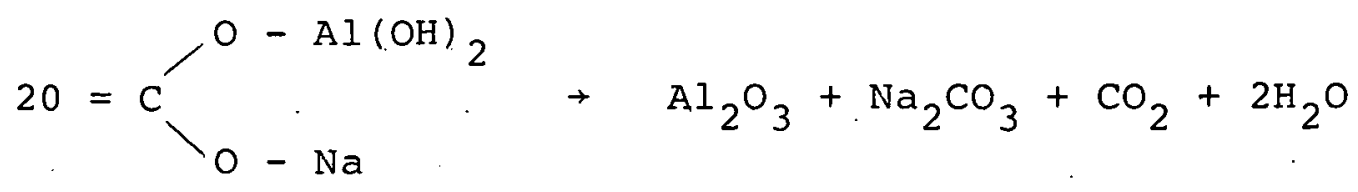

(Dawsonite II)

In the ALSAR unit, a weak caustic leach solubilizes the resultant aluminum values indicated in the equations above. The amount of solubilized aluminum is a function of: (1) the temperature of calcination, (2) the alkali concentration of the leaching liquor, and (3) the degree of surface contact between the shale and leaching solution. Previous investigators are undecided as to the dominance a. of either reaction scheme for dawsonite decomposition. It is assumed in the process design presented in $\$ 2.5$ that the leach liquor is nearly saturated with respect to sodium aluminate (Dawsonite I reaction) and that the decomposition of the leach liquor to an is. aluminum-value precipitate is accelerated by liquor seeding.

$2.5 \quad$ MLSAR (Alumina,/SnAta Ash Recovery) UNIT

There are a number of published or patented processes for the recovery of alumina and soda ash from oil shale containing nahcolite and dawsonite. Van Nordstrand (1968, U.S. Patent) describes a process for the recovery of aluminum values from oil shale using a sodium hydroxide leach at elevated temperatures, and precipitating the aluminum component by treating the leach solution with carbon dioxide. Nielsen (1969), similarly discusses a sodium hydroxide leach system coupled with a lime desilication circuit and carbon dioxide precipitation of the aluminum components. Hall and Hass (1970, U.S: Patent) patented a process for recovering a water-soluble sodium aluminate from processed shale by leaching at low temperatures 
and atmospheric pressure with an aqueous soda ash solution. Weichman (1974, U.S. Patent) discloses a process using a weak caustic leach of processed shale with $\mathrm{CO}_{2}$ treating (carbonation) to remove alumina trihydrate. A report by the U.S. Bureau of Mines (1972, II) describes a mineral co-product recovery facility utilizing a sodium hydroxide (. $8 \mathrm{~N}$ solution) leach. Lime is added during leaching to causticize the natural sodium carbonate for leaching and to desilicate the pregnant liquor prior to carbonation precipitation of the alumina trihydrate.

Characteristic of the more recent processes is the presence of a lime de-silication circuit for the control of silica concentration levels in the precipitated alumina (alumina trihydrate). Specifications for cell-grade alumina require that the alumina contains less than .03 weight percent silica (as $\mathrm{SiO}_{2}$ ) to be of economic value.

A different approach to silica-level reduction involves controlling the solubility of the silica components in the leaching cycle rather than desilication prior to precipitation. Hass (1975, U.S. Patent), has patented a prnsesa for alumina rcoovcry from processed shale involving a low temperature leach $\left(25^{\circ} \mathrm{C}\right)$ with a dilute alkaline leach liquor. Contact time with the weak-base liquor is quite short and the low temperature of leaching inhibits the coleaching of silica. Precipitation of the pregnant liqquor is carriedout at an elevated temperature $\left(60-75^{\circ} \mathrm{C}\right)$ using an alumina trihydrate seed for precipitation rather than carbonization (acidizing). The elevated temperature of the precipitation circuit inhibits coprecipitation of silica with the product.

The recovery process designed for the present study is modified from the Hass methodology (Hass, 1975, U.S. Patent $\$ 3,859,413$ ) and is adapted to a commercial-scale, conceptual process configuration. 


\section{PAGES II.31 to II.32 WERE INTENTIONALLY LEFT BLANK}




\section{ALUMINUM AND SODA ASH RECOVERY FACILITIES: CASE 3}

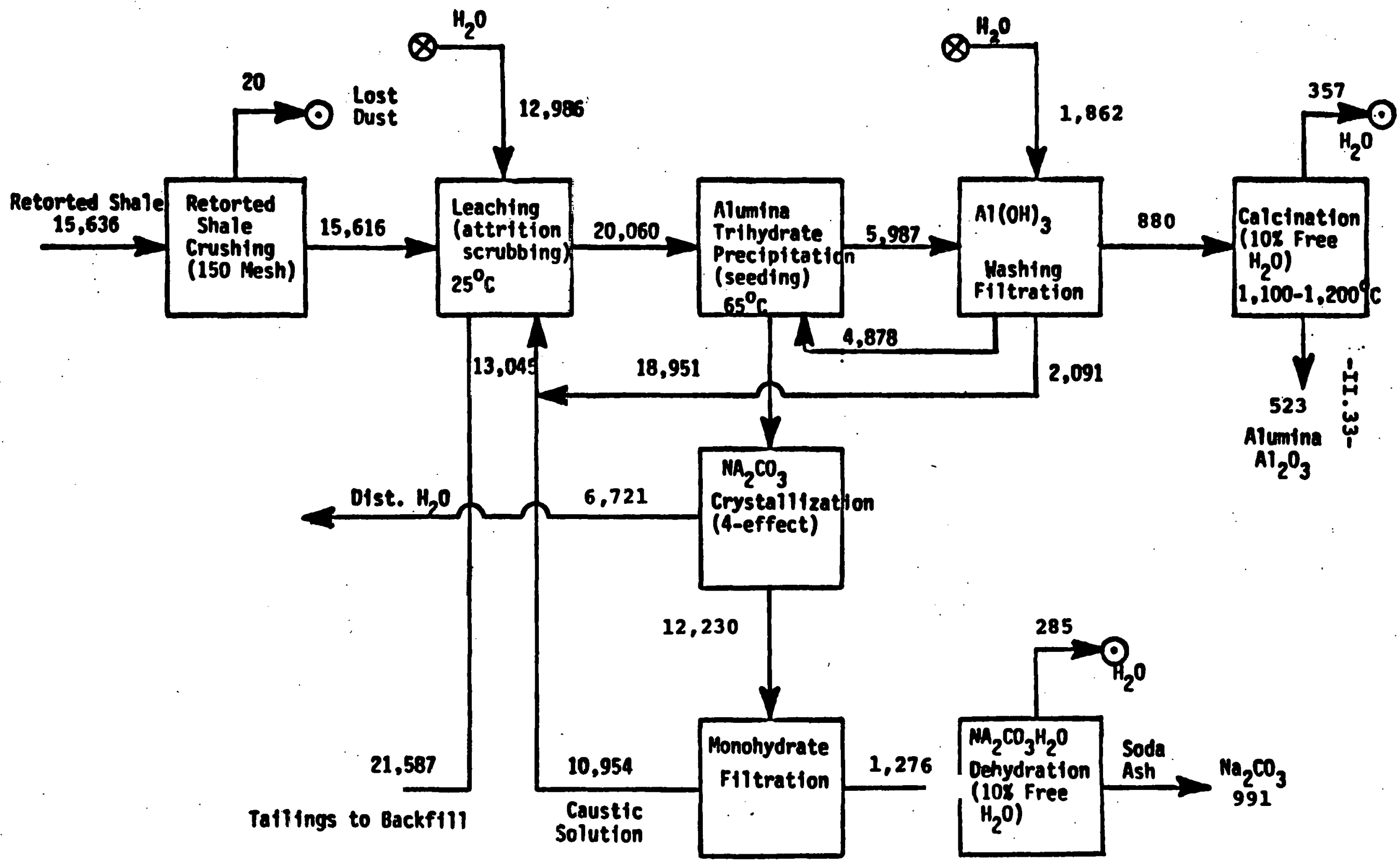




\section{Retorted Shale Crushing}

In the Case (3) analysis, 15,636 TPD of retorted shale enters the crushing unit for reduction to 150 mesh-size material. The selection of material size is based on the following two factors:

(1) Leaching of the soluble aluminum values is strongly surface-active dependent; and,

(2) Rapid contact of the shale with the leach liquor in attrition scrubbers minimizes silica dissolution.

A combination of short-head cone crushers and tube (rod) mills is used in the crushing stage. A dust loss of 20 TPR is accounted for in the Case (3) analysis. Environmental control equipment consisting of baghouses and cyclone dust collectors is utilized.

\section{Leaching}

The pulverized retorted shale contains the soluble mineral values produced by the decomposition reactions in the retorting phase. The material is rapidly wetted in attrition-type scrubbers at ambient temperatures $\left(25^{\circ} \mathrm{C}\right)$ and a 40 percent net solids content.

Several parameters affecting the leaching operation include: (1) percent solids content, (2) temperature, (3) NaOH concentration, and (4) leach contact time. The $\mathrm{NaOH}$ concentration yielding optimum extraction of the aluminum values is found to be approximately $20 \mathrm{~g} / 1$ (Hass, 1975, U.S. Patent). The precipitation reaction (Equation (D), \$2.5.1) produces two moles of caustic per mole of alumina precipitated. The generation of caustic from the decomposition of the sodium aluminate leach liquor indicates that the process is self-sufficient in caustic requirements thereby eliminating this potential operating cost from the process. 
If sodium hydroxide levels exceed the stipulated concentration of $20 \mathrm{~g} / 1$, excessive silica concentration levels in the leach liquor result. Exhibit 2-9 displays the leaching circuit for the ALSAR unit. A counter-current washing scheme enables excess caustic to exit the system with the process tailings, thus rendering the leach concentration levels balanced. The purge rate of the caustic is varied by the recycle bleed stream return and the addition of fresh water to the leach system.

Sodium carbonate forms a portion of the leach liquor from the decomposition reactions of nahcolite and dawsonite II (Equations (A) and (C) $\$ 2.5 .1$ ). The extent to which the sodium carbonate contributes to the solubility of the aluminum values is unknown (Hass, 1975, U.S. Patent). However, concentrations of $\mathrm{Na}_{2} \mathrm{CO}_{3}$ should not exceed $150 \mathrm{~g} / \mathrm{l}$ in the leaching solution in order to prevent high alkalinity which significantly enhances silica solubility. Control of the sodium carbonate concentration is achieved by the leaching circuit purge (to the "tailings") or by the crystallization of soda ash from the precipitation overflow. Tailings exiting the leaching iunit are approximately 62 percent solids. in

Requirements for wetting the pulverized shale include: a fixed organic carbon content of less than five percent, and (2) virtually no benzene soluble oil may be contained in the material. In the direct retorting process considered, the fixed carbon content is less than one percent for the shale leaving the retort.

Pressure (leaf-type) filters and rotary (vacuum-type) filters are employed in the leaching circuit to eliminate all shale particles from the leach liquor. Particles not removed will act as seeding crystals in the alumina precipitation section. 


\section{Exhibit 2-9}

\section{ALSAR PLANT \\ LEACHING SECTION MATERIAL BALANCE \\ Tons Per Day}

Crushed

Retorted

Shale ( 150

$\frac{15,616}{\text { mesh })}$

LEACH ING

23,424

18,980

15,943

7,342

13,045

COUNTER-

CURRENT

WASHING

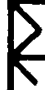

CAUSTIC

SOLUTION

W
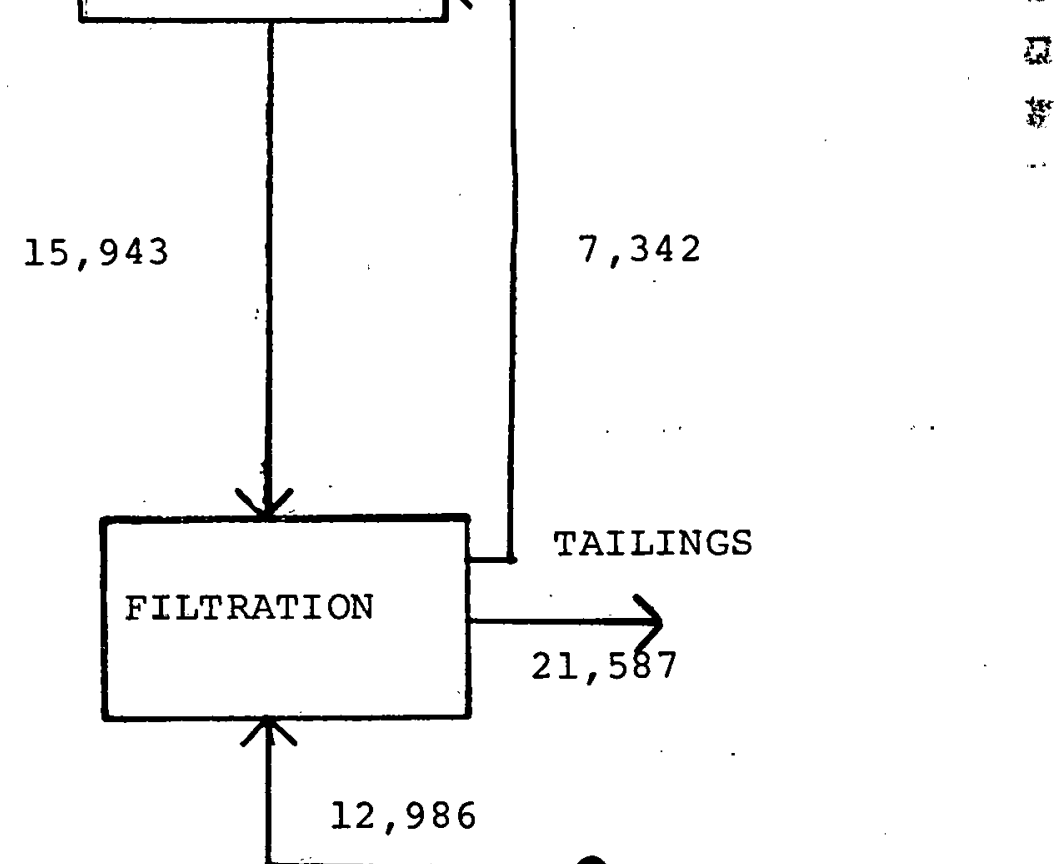


\section{Alumina Trihydrate Precipitation}

Equation (D) (\$2.5.1) describes the decomposition of the sodium aluminate leach solution. A 5:1 seed ratio (weight ratio of alumina trihydrate seeds to alumina in solution) is used to accelerate the precipitation process. The temperature of the precipitating solution is held at $65^{\circ} \mathrm{C}$ to inhibit the co-precipitation of silica (Hass 1975, U.S. Patent). The specifications of the resulting alumina (post calcination) conform to the product standards of cell-grade alumina (<.03 wt. percent silica, $\mathrm{SiO}_{2}$ ). The percent of alumina precipitation is 54 percent of the net solubilized alumina per cycle for a precipitation time of one hour. This defines the total process efficiency for the recovery of alumina from shale.

\section{Alumina Trihydrate Filtration and Calcination}

The alumina is separated in a hydro-classification unit with the fine crystals recycled back (with barren liquor) to the precipitation circuit for seeding. Coarse fractions are filtered and washed with fresh water and sent to the calcination unit fur liydroreduction. Filtrate from the washing cycle is recirculated with the barren liquor to the leaching unit for filter cake washing.

The alumina trihydrate is calcinater in conventional fluidizedbcd calcination ki.l.ns fired by process gas from the retort unit. Approximately 2,700 BTU/lb are required for calcination of the alumina at $1,200^{\circ} \mathrm{C}$; corrected for surface water (10 percent free water) and kiln efficiency. High-grade $\alpha$-alumina is produced according to the following reaction:

$$
\text { (E) } \mathrm{Al}_{2} \mathrm{O}_{3} \cdot 3 \mathrm{H}_{2} \mathrm{O} \rightarrow \mathrm{Al}_{2} \mathrm{O}_{3}+3 \mathrm{H}_{2} \mathrm{O}
$$


Soda Ash Crystallization

Soda ash $\left(\mathrm{Na}_{2} \mathrm{CO}_{3}\right)$ is recovered from the alumina precipitation overflow by crystallization in multiple-effect vacuum evaporators. The soda ash content of the circulating liquor is brought to a nominal $150 \mathrm{~g} / 1$ concentration post crystallization. Accounting for total solutes, the saturation solubility of the sodium carbonate at crystallization temperature is approximately $428 \mathrm{~g} / \mathrm{l}(455 \mathrm{~g} / 1$ or 30 percent in pure water).

In the Case (3) analysis approximately 6,721 TPD of water is evaporated in a four-effect crystallizer to produce 1,160 TPD of monohydrate soda ash. Large quantities of water are evaporated because of the dilute caustic levels required for silica control. The leach overflow must be devoid of hydrocarbon residue for control of crystallizer foaming. Benzene soluble oil content is a critical constraint to leaching in order to obviate crystallizer foaming and plugging.

\section{Monohydrate Filtration and Dehydration}

The monohydrate product from the crystallization section is filtered and discharged to the dehydration unit. Barren liquor is recycled to the leaching unit through an aerial cooling-tower system to cool the liquor to ambient temperatures $\left(25^{\circ} \mathrm{C}\right)$ prior to leaching.

\section{5 .3 Design and Case Analyses}

The flow diagrams and mass balances of Exhibits (2-8) and (2-9) pertain to the analysis of Case (3). Conceptual process design is adapted from the Case (3) analysis for the remaining four cases examined in the study. Equipment duties are adjusted to reflect the net flow-through of retorted shale material, and the overall process flow and chemical balances are assumed to be identical for 
each case. In the Case (5) analysis, the large processing volumes dictate that counter-current wetting units are employed in conjunction with the rapid attrition scrubbers in the leaching facility.

Exhibit (2-10) displays the net soda ash and alumina output for the five cases examined. The production of mineral co-products is assumed to be linear within the constraint of "rich-mineral" cases. The total process efficiency for conversion of the dawsonite to alumina (2:1 mole ratio) is approximately 50 percent.

The equipment inventory for the fundamental case (Case (3)) is selected on the basis of equipment duties and capacities. Exhibit (2-11) displays the inventory for major equipment purchases in the AlsAk unit.

The remaining cases are designed on the basis of total material flow-through; with larger (or smaller) processing volumes the equipment inventory is adjusted by: (1) multiple-unit addition (subtraction) arcounting for process economies, (2) expand (contract) equipment duties, or (3) select new equipment technology.

Process scaling, particularly to the smaller cases (Cases (1) and (2)), involves the non-linear adjustment of equipment duties. Piping, and boiler duties are examples of equipment types with nonlinear scaling relationships - a facility of ten percent processing capacity of another does not necessarily contain a piping network of pipes one-tenth the size of the larger plant. Every effort has been made to ascertain and implement these scaling relationships in the design and costing of the five cases examined. 


\section{Exhibit 2-10}

\section{PRODUCT SLATES FOR THE FIVE CASES}

\begin{tabular}{|c|c|c|}
\hline $\begin{array}{l}\text { Raw Material } \\
\text { Lean Minerals } \\
\text { Rich Shale }\end{array}$ & $\begin{array}{l}\text { Case 1 } \\
\text { Shale: } 21,053 \text { TPD } \\
0 \text { il: } 13,571 \text { BPD } \\
\text { Nahcolite: -- } \\
\text { Alumina: } 75 \text { TPD } \\
\text { Soda ash: } 78 \text { TPD } \\
\text { (1 retort module) }\end{array}$ & $\begin{array}{l}\text { Case } 2 \\
\text { Shate: } 84,212 \text { TPD } \\
0 \text { ill: } 54,254 \text { BPD } \\
\text { Nahcolite: -- } \\
\text { Alumina: } 300 \text { TPD } \\
\text { Soda ash: } 312 \text { TPD } \\
\text { (4 retort modules) }\end{array}$ \\
\hline $\begin{array}{l}\text { Rich Minerals } \\
\text { Rich Shale } \\
\end{array}$ & $\begin{array}{l}\text { Case } 3 \\
\text { Shale: } 25,316 \text { TPD } \\
\text { 0il: } 15,639 \text { BPD } \\
\text { Nahcolite: 4,050 TPD } \\
\text { Alumina: } 523 \text { TPD } \\
\text { Soda ash: } 991 \text { TPD } \\
\text { (1 retort module) }\end{array}$ & $\begin{array}{l}\text { Case } 4 \\
\text { Shale: } 75,948 \text { TPD } \\
\text { Oil: } 46,917 \text { BPD } \\
\text { Nahrolite: } 12,150 \text { TPD } \\
\text { Alumina: } 1,569 \text { TPD } \\
\text { Soda ash: } 2,973 \text { TPD } \\
\text { (3 retort modules) }\end{array}$ \\
\hline $\begin{array}{l}\text { Rich Minerals } \\
\text { Lean Shale }\end{array}$ & Not analyzed & $\begin{array}{l}\text { Case } 5 \\
\text { Shale: } 126,582 \text { TPD } \\
0 \text { il: } 52,132 \text { BPD } \\
\text { Nahcolite: } 20,253 \text { TPD } \\
\text { Alumina: } 2,616 \text { TPD } \\
\text { Soda ash: } 4,956 \text { TPD } \\
\text { (5 retort modules) }\end{array}$ \\
\hline
\end{tabular}




\section{Exhibit 2-11}

ALSAR UNIT

INVENTORY : MAJOR EQUIPMENT

\section{CRUSHING}

Cone Crusher, std. (7')

Cone Crusher; short-head

Tube Mills

Screens

Feeders (Apron)

Bins

Hoppers

Conveyors

Blowers

Cyclones

Baghouses

LEACHING

Attrition Scrubbers

Filters (Leaf and rotary)

Thickeners

Tanks

Pumps

Rins

$\left.\mathrm{Al}_{\mathrm{O}} \mathrm{OH}\right)_{3}$ PRECIPITATION/WASHING

Precipitation Tanks

Hydro Classifiers

Mechanical Classifiers

Thickeners

Filters

Tanks

Pumps
$\left.\mathrm{Al}_{\mathrm{O}} \mathrm{OH}\right)_{3}$ CALCINATION

Calcination $\mathrm{Kilns}$

Rotary Coolers

Blowers

Conveyors

Scrubbers

Hammermill (sizing)

storage silos

$\mathrm{Na}_{2} \mathrm{CO}_{3}$ CRYSTALLIZATION/FILTRATION

Evaporators (4-effect)

Boilers (Waste heat)/Stack

Condensate Tank

Pumps

Centrifugal Filters

Tanks

$\mathrm{Na}_{2} \mathrm{CO}_{3}$ DEHYDRATION

Dehydration Kilns

Rotary Coolers

Blowers

Cyclones

Conveyors

storage silos

PRODUCT HANDLING

Covered Storage

Loading Facilities 


\subsubsection{Plant Energy Balance: Case (3)}

In addition to the mass balance calculations displayed in the previous sections, a detailed energy balance was required in order to determine the potential of using the low BTU offgas from the retort as a primary fuel source for mineral co-production. Soda ash crystallization, alumina calcination, and nahcolite calcination are the three major energy consumptive plant sections within the integrated shale oil/mineral co-products facility.

Based on the best available data for a circular grate-type retort (Sandell et al., (USGS); U.S. Department of the Interior, 1979; Melcher, et al., 1979; Knight, Personal Communication), a single retort module in the Case (3) analysis will produce approx-. imately $14.5 \times 10^{9}$ BTU per day as gas with a gross heating value of 90 BTU per cubic foot. The data available indicate that this production of offgas is sufficient to meet the process energy requirements of the ALSAR unit without the importation of external fuels such as coal (Ferris et al., 1978).

The distribution of the total retort offgas production over the individual plant facilities is detailed below:

Facility

Nahcolite Recovery Unit (Photosort Kiln) $\mathrm{Na}_{2} \mathrm{CO}_{3}$ Crystallizer Al $(\mathrm{OH})_{3}$ Calcination (Fluid-bed) $\mathrm{Na}_{2} \mathrm{CO}_{3}$ Dehydration Process Drives Misc. Plant (Process $\mathrm{H}_{2} \mathrm{O}$, Operations, etc.)
Energy Consumption

$10^{9}$ BTU/day

1.3

6.2

3.2

0.7

1.0

1.4

Total

13.8 
The process gas energy requirements are calculated on the basis of unit (normalized) BTU requirements, process throughputs, and net thermal process efficiencies. A fluidized calcination kiln is employed in the alumina calcining section in order to reduce the net energy required, and four-effect (vacuum) crystallizers are determined to be optimal for soda ash recovery in the particular Case (3) application. The total process gas requirement (Case (3)) for soda ash crystallization is determined to be $7.2 \times 10^{6}$ $\mathrm{BTU} / t$, and for alumina production $6.7 \times 10^{6} \mathrm{BTU} / \mathrm{ton}$ is required:

In addition to the retort offgas uses, the plant requires the use of diesel in the mining operations and electricity which must be imported from external sources. The energy requirements for all $x$
$=$
$=$
$\therefore$ five plant cases in this study are detailed in Exhibit 2-12. 


\section{EXHIBIT 2-12}

ENERGY REQUIREMENTS FOR THE SHALE OIL AND

CO-PRODUCT FACILITIES

\section{$\underline{\text { Analytic Cases }}$}

Energy Requirements

Shale Oil

- diesel, MMGPY

- electricity, MW

Alumina

- offgas, $10^{9}$ BTU/day

- electricity, MW

Süa Asli

- offgas, $10^{9}$ BTU/day.

2.6

3.2

$0.8 \quad 1.8$

- electricity, MW

0.5

2.0

12.250 .1

\section{Case 1 Case 2 Case 3 Case 4 Case 5}

$\begin{array}{rrrrr}1.1 & 4.5 & 1.3 & 4.2 & 6.9 \\ 20.2 & 73.1 & 24.3 & 69.0 & 113.0\end{array}$

3.2

9.6

16.0

16.4

47.0

78.1 
3.0 COST ESTIMATION ANALYSIS: CONCEPTUAL PROCESS

\section{General Scope}

In this chapter, the total capital and operating costs of the shale oil and mineral co-product facilities are developed for the assumed process configuration and five plant cases under examination. Power and fuel requirements for the total facility are determined, and economy-of-scale exponents for each of the major plant sections are calculated.

\section{Methodology}

Capital and operating cost estimates for the shale oil and mineral co-product facilities of Case (3) are prepared from the conceptual process engineering analysis presented in Chapter 2 . The marginal capital and operating costs for mineral co-product recovery are based on the assumed commercial-scale process configuration for the ALSAR unit. The sensitivity of the derived costs to variahle process configurations is discussed in $\$ 3.2$

Capital and opcrating sost rata is generated from an inventory of major equipment purchases for the facility. The equipment inventory for each plant section of the conceptual process (Exhibit 2-4) is determined from: (1) process-flow, mass and energy balances, and (2) projected equipment capacity and performance data. The major equipment purchases for the Case (3) process analysis, are displayed in Exhibit 3-1. The completed equipment inventory enables costengineering estimates to be prepared from capacity-cost relationships available in the literature (Popper, 1970; Herkimer, 1958; Dryden et al., 1966; and Zimmerman, 1970), and from manufacturer's price and operating quotes. 


\section{EXHIBIT 3-I}

\section{CASE (3)}

INVENTORY: MAJOR EQUIPMENT PURCHASES

s 1 MINING.

(See Exhibit 2-5)

Primary Crushing

Single Roll: Crusher (48" $x$ 72") (Ḍul-Gang)

Feeders

screens

Hoppers

Surge Bins

Conveyors

Baghouses/Blowers

S 2 NAHCOLITE RECOVERY UNIT

Gyratory Crusher (36")

Reversible Impact Crushers

Calcination Kilns (Rotary)

Photosorting Unit

Bins/Feeders

Screens

Conveyors

Blowers/Baghouses

Cyclones

Shale stockpile

Traveling stacker

storage Conveyor

Reclaim Conveyor

Transfer station 


\section{EXHIBIT 3-1-Continued}

\section{INVENTORY : MAJOR EQUIPMENT PURCHASES}

$\underline{\text { s 3. RETORT AND OIL RECOVERY }}$

Retort (I)

Frame/support

Stationary Hood

Grate \& Idler system

Idler Drive

Segregation Feeders and Distributors

Winaboxes/Hoods

Injectors/Ducts/Seals

Jackel Seals

Feeders I/O

Oil and Gas Recovery

Phase Separation Unit

Electrostatic Precipitators

De-misters/Impingement Separators

Collectors

Compressors

Blowers

Receiver Tanks/Pumps

Exchangers

Cyclones

Product Handing

Pipelines

Pumps

Tanks/Heaters 


\section{EXHIBIT $3-i-$ Continued}

INVENTORY: MAJOR EQUIPMENT PURCHASES

\$ 4 ALSAR UNIT

(See Exhibit 2-11)

\$ 5 PROCESS $\mathrm{H}_{2}$ O TREATMENT

Lime Kiln (2)

Hydrators and Mixing Tanks

Tanks (Surge) (2)

Thickeners (2)

Filters (Rotating Plate) (3)

Pump/Pipes

Coolers (Rotary).

Feeders/Blowers/Baghouses

S 6. UNDERGROUND HYDRAUIIC SHALE DISPOSAL

Mixer Unit (2)

Slurry puimping Unit (1)

Pump Drive (Ellectric) (1)

Pipe/Fittings (Valves, flanges, reducers) (13,500')

Sumps (Reciprocating)

Piping Grid

\section{\$ 7 GENERAL PLANT FACILITIES}

Utilities (Electrical, Sewage, Water)

Administration Buildings

Warehouses/Shops

Control Buildings

Support Facilities

Roads, Paving, etc. 
Case (3) is selected as the fundamental engineering concept design and costing case from which plant costs, power, and process fuel requirements for the remaining four cases are scaled. An economic scaling system is developed on a weighted-cost. distribution methodology for the extrapolation of the case (3) cost data. The scaling step involves factoring the major plant sections (Exhibit 2-4) into an inventory of principal (major-cost) equipment components and calculating scaling exponents on the basis of equipment cost/ capacity functions. The installed-plant equipment capital and material operating costs are calculated for the four remaining cases by using the derived scaling exponents. Total operating costs for the plant sections are determined by the development of operating and maintenance labor schedules, and plant section power and process fuel requirements. Cost sensitivity to site-specific parameters (exclusive of resource grade) are not considered. It is assumed, however, that the general plant-layout in all five cases is identical with the scale of each particular case facility.

The scaling procedure adopted accounts for major economies of scale and non-linear effects in the cost-scaling analysis. Major plant seclivis are trcatcd individual1y and, scaling exponents for each section are listed in $\$ 3.1 .2$.

A summary of capital and operating costs is derived for eacih major plant section (Exhibit 2-4) under each of the five cases. In Attachment 2, discounted cash flow (present worth) analyses are performed using the derived data. 


\subsection{FUNDAMENTAL COST ANALYSIS: CASE (3)}

\subsubsection{Case (3) - Capital Cost Analysis}

Capital and operating cost estimates for Case (3) are derived from the conceptual process engineering analysis presented in Chapter 2. The capital cost estimates employed are generally called "study estimates" and are prepared from process flowsheets and a minimum of equipment data. The accuracy of such estimates are typically reliable to a 25 percent tolerance from the actual process cost. The total plant equipment inventory is determined from process flowcharts, and calculated mass and energy balances. In Exhibit 3-1 the principal pieces of equipment for each major plant section are shown for the case (3) analysis. The mining equipment inventory is indicated in Exhibit 2-5, and the inventory for the ALSAR unit is shown in Exhibit 2-11.

Detailed equipment duties are calculated for the major equipment purchases shown in Exhibit 3-1, and an estimate of the capital firstcosts of the specified equipment is derived from published cost data and manufacturer's quotes. Cost data is updated to FY1980 dollars by the Marshall and Stevens Chemical Plant Index (Chemical Engineering, March, 1980). An installation labor cost is obtained for each piece of equipment in order to estimate installation/ deployment costs. Installation costs vary from 5 to 75 percent of the net listed purchase price depending on equipment type.

The total installation costs of the plant sections are completed by tabulating plant installation factors, (PIF's), for foundations, structures, piping, ducts, electrical systems, instrumentation, insulation and coverings. The PIF percentages are individually tailored to each of the major plant sections and are obtained from the literature (Peters, 1958). These factors are functionally dependent on the plant section process and material handled according 
to the following catagories: (1) thermal or non-thermal processing, (2) fluids handling, (3) solids handling, (4) combination fluids and solids handling. The total direct equipment cost (purchase price plus installation) is factored by the PIF ratios to obtain the total (direct) unburdened plant section capital cost.

The direct capital costs developed are the base-costs for each unit to purchase the essential equipment components and construct the individual plant sections. These costs are further "burdened" to include the unaccounted costs of interconnecting the individual units of the facility. The burdened costs reflect the "as-installed" costs of the total plant facility, and are detailed in Attachment 2 of this study.

Exhibit 3-4 displays the unburdened capital costs for the major plant groupings under case (3). In this exhibit the major plant sections have been grouped into the specific manufacturing cost catagories utilized in the discounted cash flow analyses of Attachment 2. The capital (and operating) costs displayed in Exhibit 3-4 for major plant sections of the ALSAR unit have been cross-checked against coșts for corresponding unit-processing operations in analogous industries. This examination lends support to the derived costs under the commercial-scale process configuration assumed. Capital costs for the remaining four cases examined are derived by exponential scaling as discusscd in the following section.

\subsubsection{Capital cost Scaling}

Extrapolation of the calculated case (3) costing data is achieved by a weighted-average cost scaling methodology. This procedure is outlined in the following steps: 
(1) The major plant sections are factored into principal equipment cost-centers. The cost-centers contain the majorcost equipment components withïn each plant section.

(2) Functional relationships between equipment capacities (duties) and associated unit costs are utilized to compute the scaling exponent for each principal equipment cost-center (Popper, 1970; Chase, 1970).

(3) A numerical weight assigned to each principal costcenter (and equal to the normalized equipment cost) enables a net scaling exponent for each major plant section (Exhibit 2-4) to be derived.

(4) The capital and operating costs of the entire oil shale/ mineral co-products facility are derived by scaling the individual plant sections to the case under consideration by the following formula:

$$
\begin{aligned}
c_{2}= & c_{1}\left(s_{\varepsilon}\right)^{x} \\
c_{1}= & \text { Cost of case (3) plant section. } \\
s_{\varepsilon}= & \text { Scaling factor determined by net processing } \\
& \text { volume assuming efficiency }(\varepsilon) . \\
x= & \text { Net scaling exponent for each plant section. }
\end{aligned}
$$

Once the individual plant sections are scaled, the total unburdened facility cost is obtained by summation of the derived capital (and operating) costs. In this manner the various plant sections are treated individually and accurate cost estimates are obtained (within the probable error of the Case (3) base-costs multiplied by a second-order propagation of error factor). 
Exhibits 3-2 to 3-6 display the scaled unburdened capital (and operating) costs for the five cases examined. The basecosts displayed are utilized to compute the manufacturing costs of shale oil. and mineral co-products in Attachment 2 of this study.

Exhibit 3-7 shows the calculated scaling exponents for the major plant sections. This chart indicates the relative economies of scale for unit processing sections within a shale oil/mineral co-products facility.

3.1 .3 Case (3) - Operating Cost Analysis

The estimated operating costs are based on 364 days of operation per year with a 24 hour operating day. Operating costs displayed in Exhibits 3-2 to $3-6$ are factored into materials and labor (M\&L) costs, power, and process gas components. The total labor cost is further factored into operating and maintenance-labor cost categories in the financial analysis of Attachment 2 .

The materials and supplies cost component is developed from literature data, industrial unit operating costs, and manufacturer's quotes for the Case (3) analysis. Material and supplies costs are extrapolated from the case (3) data to the remaining cases by using a separately derived sequence of engineering scaling exponents. These operating cost exponents are based on the functional dependence of unit processing costs to net plant throughput. For the ALSAR unit, the net materials and supplies operating exponent is .81 in the Case (3) to Case (5) cost scaling analysis. Direct labor costs (operating and maintenance) for the case (3) analysis are calculated from detailed manning charts derived for each major plant section. The direct labor cost is estimated by assigning 3.5 men to each operating position with a 24-hour, 7-days per week schedule. operating and maintenance labor schedules are defined for the remaining cases and the total operating costs for each plant section 


\section{EXHIBIT 3-2}

\section{Case 1 Unburdened Costs}

(Dollars in Millions)

Facility

Mining/Primary Crushing

Nahcolite Recovery Unit

Retort/Oil and Gas Handling

Process and plant $\mathrm{H}_{2} \mathrm{O}$ Facilities

Slurry Disposal

General Plant Facilities

ATSAR PTIANT
Capital Cost

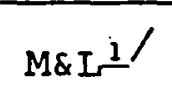

$27.7 \quad 17.6$

$112.9 \quad 15.9$

3.691 .89

1.653 .02

10.3 .3 .08
1. 3

7.4

1.3

3. 0

.67

(MW)

7.2

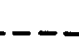

$.74 \frac{3}{1}$

.10

$-1$
Process Gas

( $\left.10^{9} \mathrm{BTU} / \mathrm{day}\right)$

Retorted shale

23.45 .35

11.3

Crushing/Leaching

$\mathrm{Al}(\mathrm{OH})_{3:}$ Precipitation/

$2 \cdot 3$

.49

.6

Washing

$\mathrm{Al}(\mathrm{OH})_{3}$ Calcination

2.5

.31

.2

.50

$\mathrm{Na}_{2} \mathrm{CO}_{3}$ Crystallization/

5.21 .25

.7

2.5

Filtration

$\mathrm{Na}_{2} \mathrm{CO}_{3}$ Dehydration

$.75 \quad .10$

.1

.1

Product Handing

1

$I_{\text {Material and Labor operating cost comporients }}$

${ }^{2}$ Diesel Fuel, U.S. Gal./Yr.

${ }^{3}$ Does not include recycle gas to retort 
EXHIBIT $3-3$

Case 2 Unburdened Costs

(Dollars in Millions)

Facility

Mining/Primary Crushing

Nahcolite Recovery Unit

Retort/Oil and Gas Handling

Process and Plant

$\mathrm{H}_{2} \mathrm{O}$ Facilities

Slurry Disposal

General Plant

Facilities

\section{ALSAR PLANT}

Retorted Shale

Crushing/Leaching

$\Lambda I(\mathrm{OH})_{3:}$ Preripitation/

Washing

$\mathrm{Al}(\mathrm{OH})_{3}$ Calcination

$\mathrm{Na}_{2} \mathrm{CO}_{3}$ Crystallization/

Filtration

$\mathrm{Na}_{2} \mathrm{CO}_{3}$ Dehydration

Product Handling

\section{Capitai}

Cost

$66.7 \quad 64.2$

$355.4 \quad 53.1$

13.4

6.8

$6.7 \quad 12.2$

22.7

6.8

29.5

$2.65 \frac{3}{}$

(MW)

23.6

4.7

.2

12.4

2.9

1.5
Process Gas

( $10^{9} \mathrm{BTU} /$ day) $\left(4.46 \times 10^{6}\right) \underline{2}$

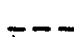

2

$--$ 
EXHIBIT $3-4$

Case 3 Unburdened costs

(Dollars in Millions)

Facility

Mining/Primary

Crusting

Nahcolite Recovery Unit

Retort/Oil and Gas Handling

Process and Plant

$\mathrm{H}_{2} \mathrm{O}$ Facilities

Slurry Disposal

General Plant

Facilities
Capital Cost

29.9

33.3

112.7

4.0

2.02

1.9

3.95

10.3

3.02

1.3

Power

(MW)

8.16

2.36

1.28

7.45

$0.24 \underline{3}^{\prime}$

1.4

.07

3.6

.67

Process Gas

$\left(10^{9} \mathrm{BTU} /\right.$ day $)$

$\left(1.29 \times 10^{6}\right) \underline{2}$

\section{8}

I

\section{ALSAR PLANT}

Retorted shale

Crushing/Leaching

Al $(\mathrm{OH})_{3:}$ Precipitation/ Washing

$\mathrm{Al}(\mathrm{OH})_{3}$ Calcination

$\mathrm{Na}_{2} \mathrm{CO}_{3}$ Crystallization/ Filtration

$\mathrm{Na}_{2} \mathrm{CO}_{3}$ Dehydration

Product Handling
26.3

6.49

4.5

1.07

1.2

13.3

2.37

0.75

3.19

12.3

3.01

1.75

6.18

3.9

1.42

0.75

0.75

2. 8

1.03

0.9 
EXHIBIT $3-5$

Case 4 Unburdened Costs

(Dollars in Millions)

$\underline{\text { Facility }}$

Mining/Primary Crushing

Nahcolite Recovery Unit

Retort/OiI and Gas Handling

Process and Plant

$\mathrm{H}_{2} \mathrm{O}$ Facilities

Slurry Disposal

General Plant

Facilities

:ALSAR PLANT

Retorted Shale

Crushing/Leaching

$n I(\mathrm{OH})_{\mathrm{s}}$ Preripitation/ Washing

$\mathrm{Al}(\mathrm{OH})_{3}$ Calcination

$\mathrm{Na}_{2} \mathrm{CO}_{3}$ Crystallization/ Filtration

$\mathrm{Na}_{2} \mathrm{CO}_{3}$ Dehydration

Product Handing

\section{Cápital} Cost

$59.3 \cdot 57.1$

90.6

281.0

10.4

5.199 .11

19.9

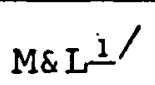

8.70

41.9

5.79

9.19
$60.3 \quad 14.0$

10.9

2.98

35.3

7.06

8.95

2.52

3.21

9.0
9.7

Operating Costs

\section{Power}

(MW)

21.8

7.0

21.3

4. 2

10.8

3.9

2.01

3.84

.2

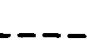

Prucess Gas

( $10^{9} \cdot$ BTU/day)

$\left(4.2 \times 10^{6}\right) \underline{2}$

$2.28 \underline{3}^{\prime}$

${ }^{1}$ Material and Labor operating cost components

${ }^{2}$ niesel Fuel, U.S. Gal./Yr.

voes not include recycle gas to retort 


\section{EXHIBIT $\quad 3-6$}

Case 5 Unburdened Costs

(Dollars in Millions)

Facility

Mining/Primary

Crushing

Nahcolite Recovery

unit

Retort/Oil and Gas Handling

Process and Plant

$\mathrm{H}_{2} \mathrm{O}$ Facilities

Slurry Disposal

General Plant

Facilities

ALSAR PLANT

Retorted Shale

Crushing/Leaching

$\mathrm{Al}(\mathrm{OH})_{3:}$ Precipitation/ Washing

$\mathrm{Al}(\mathrm{OH})_{3}$ Calcination

$\mathrm{Na}_{2} \mathrm{CO}_{3}$ Crystallization/ Filtration

$\mathrm{Na}_{2} \mathrm{CO}_{3}$ Dehydration

Product Handling

\section{Capital Cost}

104.5

109.9

425.4

63.7

16.5

7.97

8.2

14.1

25.8

14.6

88.0

19.5

3.24

8.27

14.4

3.94

5.36

17.1
Operating Costs

Power

(MW)

Process Gas

( $10^{9}$ BTU/day)

33.1

11.4

6.20

37.0

$3.40 \frac{3}{1}$

.34

7.0

$\left(6.93 \times 10^{6} \mathrm{gal} / \mathrm{yr}^{2}\right)^{2}$

18.0

5.9

3.4

$I_{\text {Material and Labor operating cost components }}$

2 Diesel Fuel, U.S. Gal./Yr.

${ }^{3}$ Does not include recycle gas to retort 


\section{EXHIBIT $3-7$}

\section{COST SCALING EXPONENTS ${ }^{1}:$ MAJOR PLANT SECTIONS $^{-}$}

\section{$\underline{\text { Plant Section }}$}

Mining

Primary Crushing

Nahcolite Recovery Unit

Retort Module

Syncrude Handling/Distribution

Process $\mathrm{H}_{2} \mathrm{O}$ Treatment

$\mathrm{Plant} \mathrm{H}_{2} \mathrm{O} /$ Wells/Mine Dewatering

Hydraulic Shale Disposal

General Plant Facilities
Capital cost

Exponent $(x)$

\section{ALSAR PLANT}

Retorted Shale Crushing

Leaching

Al(OII) ${ }_{3}$ Frccipitation

$\mathrm{Al}(\mathrm{OH})_{3}^{3}$ Calcination

$\mathrm{Na}_{2} \mathrm{CO}$ Crystallization

$\mathrm{Na}_{2}^{2} \mathrm{CO}_{3}^{3}$ Dehydration

Product Handling
.781

.70

.92

.831

.67

.73

.98

.89

.57

${ }^{l}$ Formula for evaluation of enlarged plant cost $\left(C_{2}\right)$ from base-cost $\left(C_{1}\right): \quad C_{2}=C_{1}\left(S_{\varepsilon}\right), S_{\varepsilon}=\varepsilon \cdot\left(\frac{S_{1}}{S_{2}}\right), \varepsilon=$ net processing efficiency. 
determined as shown in Exhibits 3-2 and 3-6. The defined labor schedules include all personnel necessary to operate and maintain the plant facilities. Labor costs (wages) are calculated from data published by the U.S. Bureau of Labor Statistics and reflect the anticipated growth of these costs under a realistic scenario of shale oil development in the Western United States.

As previously discussed, the operating costs displayed in Exhibits 3-2 to $3-6$ are unburdened with respect to plant operation and maintenance premiums. Operating burdens for indirect labor and maintenance costs are assumed in the financial analysis of Attachment 2 .

\subsection{PROCESS CONFIGURATION AND COST SENSITIVITY}

The ALSAR process configuration selected (\$2.5) is conceptual inasmuch as actual testing of the chemical processes employed has not proceeded much beyond the bench-scale level (Hass et al.; 1975). Several alternate alumina and soda ash recovery plant designs exist, and therefore it is imperative that the variatinn of capital and operating costs under alternate processing scenarios be determined.

The unburdened capital and operating costs derived for the ALSAR unit under the five cases of resource grade, mineral content, and plant capacity have been examined for their sensitivity to process configuration and critical design parameters. Two alternate processing scenarios are selected for examination as defined below:

Process Scenario (1): Aluminum trihydrate seeding for the nucleation and precipitation of aluminum values from the leach liquor is replaced by $\mathrm{CO}_{2}$ precipitation (carbonization). The acidizing of the leach liquor (together with adjusted partial pressures) precipitates alumina which is then calcined according 
to the conventional practice. Leaching procedures are as in the ALSAR design ( $\$ 2.5)$.

Process Scenario (2): Attrition scrubbing of the retorted shale (as in the ALSAR unit) is replaced by tank-wetting and leaching, with a leaching-time duration of up to six-hours. A desilication circuit (lime process) is added to the recovery unit between the leaching and alumina precipitation stages to remove solubilized silica occuring as a result of extended leaching time. Precipitation of the alumina is accomplished. by trihydrate seeding.

The variation of capital and operating costs with process \# configuration is presented in Exhibit 3-8. The cost variation data presented has been normalized to the maximum probable error-bound $\therefore$ of 25 percent for the original cost study-estimate of the ALSAR $\approx$ unit (\$2.5). The cost variation is defined and calculated as the - maximum probable variation from the estimated costs of the ALSAR $\therefore$ unit under the rase (3) assumptions. Further, it is assumed that $\therefore$ recovery efficiencies for the alternate processing scenarios are ... constant therefore yielding no inherent advantage to any one process design. This assumption is broadly supported in the available literature (U.S. Bureau of Mines(II) Staff, 1972; Weichman 1974; Ferris, 1978; Hass, 1975).

As indicated in Exhibit 3-8, the variation of capital cost under the alternate process configurations is well imbedded within estimation error. This result is intuitive insofar as the simplification of one process section (i.e., leaching under Process Scenario (2)), implies increasing the complexity (and cost) of another plant section (i.e., adding a desilication circuit). The capital cost trade-offs under the alternate processing configurations are therefore relatively "in-balance" under the assumptions of mineral 
EXHIBIT $3-8$

CAPITAL AND OPERATING COST SENSITIVITIES OF

ALUMINA AND SODA ASH RECOVERY TO SELECTED

PROCESS CONFIGURATIONS

Normalized Maximum Probable Variation ${ }^{1}$

Configuration

Process Scenario (1)

Process Scenario (2)
Capital

$\pm 7 \%$

$\pm 7 \%$
Operating

Low $\underline{\text { High }}$

$-5 \% \quad+8 \%$

$-5 \%+100^{\circ}$

${ }^{1}$ Variation of Costs from the Estimated costs of the ALSAR Unit $(\S 2.5)$. 
resource grade and recovery efficiency discussed above.

Operating costs under the álternate processing schemes present an asymmetrical variation of probabile cost. The data obtained indicate that the alternate plant configurations examined may possess higher net operating costs than the original ALSAR unit design (\$2.5). Operating costs for desilication (Process Scenario (2)) include lime-purchase costs and additional costs for lime kiln operation and maintenance. In Process Scenario (1), operating costs are increased by employing pressurized precipitation vessels. The carbor dioxide source is assumed to be recycle flue-gas from the retort unit compressed to 1.75 atmospheres. 


\section{SUMMARY}

The capital cost of the alumina and soda ash recovery unit appears to be rather insensitive to process design. Operating costs display a larger sensitivity and appear higher in the alternate processing schemes examined.

In general, however, the variation of costs with process design is within an acceptable level for the economic/financial analyses executed in this study (Attachment 2). The conceptual process configuration utilized in the generation of costing data for this study appears favorably aligned.with similar alumina and soda ash recovery facilities from a process economics standpoint. None of the alumina and soda ash recovery processes in the public literature have been tested beyond a pilot-plant level, and therefore it is assumed that the cost data developed in this study is adequate for the economic analyses of shale co-products until such time as a commercial-scale operation is initiated. 


\section{BIBLIOGRAPHY}

Beard, T.N., Tait, D.B., and Smith, J.W., 1974, Nahcolite and Dawsonite Resources in the Green River. Formation, Piceance Creek Basin, Colorado: 25th Rocky Mountain Association of Geologists Field Conference Guidebook, 1974, p 101-109.

Chase, J.D., 1970, Plant Cost vs. Capacity: New Way to Use Exponents; Chemical Engineering, April 6, 1970 .

Chemical Engineering, March, 1980, Economic Indicators: Compiled Quarterly by Marshall and Swift, Inc., McGraw-Hill Department of Economics (suarterly).

Dryden, C.E., and Furlow, R.H., 1966, Chemical Engineering Costs: A Condensed Handbook of Chemical Plant Equipment and Process Costs for Cost Estimating Purposes: Engineering Experiment Station; Ohio State University, Columbus, 1966 Edition.

Dulin, J.M. and Rosar, E.C., 1975, Sodium Scrubbing Wastes, Environmental Science and Technology, 9, (7), 1975.

Dyni, J.R., Beck, P.C., Mountjoy, W., 1971, Nahcolite Analyses of Three Drill Cores from the Saline Facies of the Green River Formation in Northwest Colorado: U.S. Department of the Interior, Geological Survey.

Farris, C.B., and Mains, C.J., 1978, Dawsonite and Nahcolite Survey, Volume 1: Reserves, Technology, Economics, and Market Assessment.. Prepared by: Colorado School of Mines Research Institute, for: U.S. Department of Energy, Office of the Assistant Secretary for Conservation and Solar Applications. Contract No. EC-77-S-07-1683.

Farris, C.B., and Mains, C.J., 1978, Dawsonite and Nahcolite Survey, Volume II: Dawsonite and Nahcolite Bibliography with Abstracts. Prepared by: Colorado School of Mines Research Institute, for: U.S. Department of Energy, Office of the Assistant Secretary for Conservation and Solar Applications. Contract No. EC-77-S-07-1683.

Hall, R.N., Hass, F.C., 1970, U.S. Patent No. 3,510,255, Patented May 5, 1970. Recovery of Sodium Aluminate from Dawsonite.

Hass, Frank C., 1975, U.S. Patent No. 3,859,413, Alumina Recovery from Oil Shale Residue, Patented January 7, 1975.

Hass, F.C. and Atwood, M.T., 1975, Recovery of Alumina From Dawsonite Oil Shales: Quarterly of the Colorado School of Mines 70 (3), pp. 95=107. 
Herkimer, H., 1958, Cost Manual for Piping and Mechanical Construction: Tudor Publishing Co., Inc., New York, 1958.

Hite, R.J., and Dyni, J.R., 1967, Potential Resources of Dawsonite and Nahcolite in the Piceance Creek Basin, Northwest..Colorado: Quarterly of the Colorado School of Mines, 62, (3) pp. 585589 .

Johnson, P.W. and Peters, F.A., 1968, (January) Methods for Producing Alumina from Anorthosite: An Evaluation of a Lime-Soda Sinter Process, RI 7068, U.S. Department of Interior, U.S. Brueau of Mines.

Knight, J.H., 1978, Superior's Circular Grate Oil Shale Retorting Process, Presented to: The International Symposium on Oil Shale Chemistry and Technology, Jerusalem, Israel October, 1978.

Knight, J.H., 1977, U.S. Patent No. 4,018,868 Thermal Crushing of Alkali Compounds in the Removal of Sulfur Dioxides from a Flue Gas, Patented April, 1977.

Knight, J.H., , U.S. Patent No. 4,058,905 Method of Reducing Residence Time and Eliminating Gas Leakage Between Zones in a Cross Flow Device for Heating and Cooling Solids.

Melcher, A.G. and Farris, C.B., 1979, Report on Net Energy Analysis of Proposed Superior Oil Shale Operation: Prepared by: Colorado School of Mines Research Institute, for: U.S. Bureau of Land Management, Coluialu Slale offlce, Lenver, Lolorado, January $17,1979$.

Miller, R.L., et al., 1979, Capital and Operating Cost Estimating System Handbook: Mining, Retorting and Upgrading of Oil Shale in Colorado, Utah, Wyoming; Prepared by S'I'RAAM Engineers, Inc., for: U.S. Department of the Interior, Bureau of Iand Management, USBM Contract No. J0265049.

National Academy of Sciences, 1970, NMAS ad hoc Panel on Potentials of Aluminum Extractive Processes: Processes for Extracting Alumina from Nonbauxitic Dres, December, 1970 .

Nielsen, I., 1969, The Amazing Piceance Mineral Suite and Its Industrial Potential for Energy-Oil-Metals-Chemicals: Engineering and Mining Journal, January, 1969, pp 57-60.

Peters, M.S., 1958, Plant Design and Economics for Chemical Engineers, McGraw-Hill Book Co., Inc. New York, 1958.

Popper, H., and Staff, Chemical Engineering, 1970, Modern CostEngineering Techniques: McGraw-Hill Book Company, Inc. New York, c. 1970. 
Rhys, H.R., 1976, U.S. Patent No. 3,992,287, Oil shale Sorting, Patented November $16,1976$.

Rosar, E.C., et al., 1974, U.S. Patent No. 3,806,044, Froth Flotation Method of Separating Nahcolite from Ores Containing Nahcolite, Patented April 23, 1974.

Sandell, Jr., E.T., Brady, R.A., Barker, L.K., 1976, Mining Report for Land Exchange Application: The Superior Oil Company plus attachments): U.S. Department of the Interior, Geological Survey, Conservation Division, Area Oil Shale Office.

Savage, J.W., and Bailey, D., 1968, Economic Potential of New Sodium Minerals Found in the Green River Formation: Symposium on Chemical Engineering Approaches to Mineral Processing, 61st Annual Meeting; Los Angeles, California, Dec. 1-5, AIChE, pp. $1-29$.

Shen, J., and Smith, J.M., 1965, Diffusional Effects in Gas-Solid Reactions: I\&EC Fundamentals, 4, (3), August, 1965 pp 293-301.

Smith, J.W. and Milton, Charles, 1966, Dawsonite in the Green River Formation of Colorado, Economic Geology 61, 1966, pp 1029-1042.

Smith, J.W., Thomas, H.E., Trudell, L.G., 1968, Geologic Factors Affecting Density Logs in Shale: SPWLA Ninth Annual Logging Symposium, June 23-26, 1968 .

Smith, J.W. and Young, N.B., 1975, Dawsonite: Its Ceochemistry, $\therefore$ Thermal Behaviour, and Extraction from Green River oil shale: Colorado School of Mines Quarterly, 70, (3) pp 69-93.

Tassicker, O.J., 1976, Evaluation of Dry Alkalis for Removing Sulfur Dioxide from Boiler Flue Gasses, Prepared by: Bechtel Corp. for EPRI (Electric Power Research Institute), October, 1976, EPRI FP-207 Project 49l-1.

Trent, R.H., 1979, Ph.D. Thesis, Colorado School of Mines, Golden, Colorado, December, 1980.

U.S. Bureau of Mines, 1972, An Economic Analysis of a white Nahcolite Installation in Colorado, Option I, Circa 1971, U.S. Bureau of Mines Open-File Report 31-72.

U.S. Bureau of Mines, Staff, 1972, An Ecconomic Analysis of an Oil Shale, Nahcolite, Dawsonite Complex in Colorado, Option II, Circa 1971 U.S. Bureau of Mines Open-File Report 32-72. 
U.S. Bureau of Mines, Staff, 1972, An Economic Analysis of an Oil Shale, Nahcolite, Dawsonite Complex in Colorado, Option III, Circa 1971, Morgantown Energy Research Center, Process Evaluation Group, U.S. Bureau of Mines, U.S. Department of the Interior.

U.S. Department of the Interior, Bureau of Land Management, 1979, (DES) Draft Environmental Statement, Proposed Superior Oil Company Land Exchange and Oil Shale Resource Development: U.S. Dept. of the Interior, Bureau of I.and Management (Draft).

Van Nordstrand, R.A., 1968, U.S. Patent No. 3,389,975 Process for the Recovery of Aluminum Values from Retorted Shale and Conversion of Sodium Aluminate to Sodium Aluminate Carbonate Hydroxide. Patented June 25, 1968 .

Weichman, B.E., 1974, The Superior Process for Development of Oil Shale and Associated Minerals; Colorado School of Mines Quarterly, 69, (2) pp 25-43.

Weichman, B.E., 1974, U.S. Patent No. 3,821,353 Shale Oil and Mineral Recovery Process, Patented June 28, 1974.

Weichman, et al., 1976, U.S. Patent No. 3,930,989, Method for Reduction of Sulfur and Nitrogen Content in Hydrocarbons, Patented January 6, 1976.

Wyslouzil, D.M., 1976, U.S. Patent No. 3,962,403, Process for Separation of Nahcolite from Oil.Shale, Patented June 8, 1976.

Zimmerman, O.T., 1970, Capital Investment Cost Estimation: Cost and Optimization Engineering, Editor: F.C. Jelen, McGrawHill Book Co., Inc., New York, 1970. 
APPENDIX 2

ECONOMIC ANALYSIS 
Appendix 2

Economic Analysis

SUMMARY

This appendix presents the findings and major assumptions used in the economic analysis of shale co-products.

The results show that at a $15 \%$ return on investment in Case 3, which is a 15,639 barrel per day demonstration plant at a mineral rich site, the cost of raw shale oil is $\$ 26$ per barrel, the cost of alumina is $\$ 257$ per ton, and the cost of soda ash is $\$ 77$ per ton. This compares with estimated current market values of $\$ 25$ per barrel for raw shale oil (before hydrotreating), and $\$ 250$ and $\$ 90$ per ton domestically for alumina and soda ash, respectively. Overall, with the recovery of the co-product minerals the integrated unit is maiginally economic at current world nil prices. As the size of the plant is increased to full commercial scale, the shale oil plant becomes economic on its own and the production of the mineral co-products further improve the economics. These market values are approximate because the shale oil would need to be upgraded, a free market value for alumina does not currently exist, and both the alumina and soda ash could incur large transportation costs in delivery to markets. Importantly, included in these economic results is an escalation of $2 \%$ per year in energy costs. Thus, the costs for alumina and soda ash would not escalate while the prices of competing products would, making co-product alumina and soda ash increasingly more economic. 
INTRODUCTION

The basis for the economic analysis is the process flow diagrams and operating and capital costs developed by Energy Development Consultants (EDC) and detailed in Appendix 1.

The economic analysis assumes that the costs of the plant units are allocated to either the production of oil, alumina, or soda ash. The rationale used in this allocation is to assume that the plant initially is constructed for the production of shale oil. Then, additional facilities are added to allow alumina production. Finally, the facilities needed to produce the involuntary soda ash are added. This rationale leads to plant units being allocated in the following manner:

Shale 0il Plant

Mine

Primary Crushing

Nahcolite Recovery Unit

Retort

Water Processing

Slurry Disposal

General Plant Facilities
Alumina Plant Soda Ash Plant

Shale Crushing Crystallization

Leaching

Precipitation

Calcination

Product Handling

The nahcolite recovery unit is attributed to the shale oil plant since nahcolite must be separated prior to retorting or it could fuse in the retort and encapsule the oil matrix.

This allocation of capital and operating costs has been chosen even though some units are necessary for the production of both co-products, for example the leaching and the shale crushing. However, if it is assumed that the alumina is a primary co-product, then the units are necessary for alumina production, and the chosen allocation would be the correct one. 
Estimates of Capital and Operating Costs

The capital and operating costs developed by EDC were the base costs for each unit to essentially purchase the components and construct the individual unit. These costs must be burdened to reflect other expenses incurred in interconnecting the units and operating and maintaining the plant. The burdened capital and operating costs are shown for each case on Tables 1 through 5.

Capital Burdens. Three capital burdens were assumed. The costs developed by EDC were first escalated by $10 \%$ to reflect a fixed utilities factor. The resulting costs were then burdened by five percent for engineering and construction fees. Finally, a contingency burden of $10 \%$ was added. Thus, the total capital burden is $27.1 \%$ of the base costs developed by EDC.

Operating Burdens. Three operating burdens were assumed. The first is Total Plant Maintenance, which is five percent of the base capital costs developed by EDC; the second is Plant Operating Costs of. $15 \%$ of Total Plant Maintenance; and the third is indirect costs of $50 \%$ of labor. For the mine, only the third hurden is applicable. Thus, a burden of $20 t$ per ton mined was assumed to reflect the indirect costs on labor.

The burdened operating, labor, and material costs were developed from the details for the individual plant units that EDC provided for Case 3. These costs were scaled to the four other Cases using operating scale factors developed by EDC. 


\section{ECONOMIC ASSUMPTIONS}

The following economic assumptions were used in the analysis:

Royalties. Royalties of $12.5 \notin$ per ton mined were assumed. By assuming royalties, no acquisition costs for the resource were included.

Severance Taxes. Severance taxes of $4 \%$ of the selling price were assumed for the oil. No severance tax was assumed for the co-products.

Escalation factors. All costs were taken as be first quarter, 1980 costs, except.for energy costs. These were assumed to escalate $2 \%$ a year in real terms.

G\&A. G\&A was assumed to be $15 \%$ of the operating costs not dependent upon energy, i.e., labor and materials. During the first years when the plant was being constructed, G\&A was assumed to be $10 \%$ of the annual investment.

Construction Schedule. The construction schedule for the shale oil plant was assumed to be six years. The table below shows the percent of investment expended in each year.

$\begin{array}{rc}\text { Year } & \text { Investment, } \% \\ 1 & 10 \\ 2 & 20 \\ 3 & 20 \\ 4 & 20 \\ 5 & 20 \\ 6 & 10\end{array}$


The alumina and soda ash plants had different construction schedules, as shown in the table below.

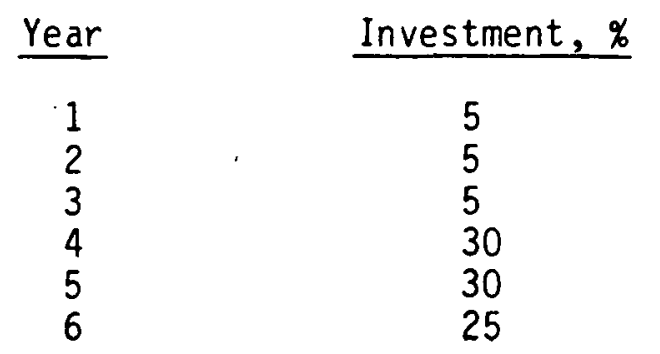

Thus the soda ash and alumina plants were assumed to be essentially constructed in half the time of the shale oil plant, but to be completed at the same time.

Plant Life. After a construction period of six years, the plant was assumed to go on-stream in the course of three years; the first year, operating at $30 \%$; the second year at 70\%; and the third year at $100 \%$ of full capacity. The plant was then assumed to operate at full capacity for 20 years.

Investment costs. Investment costs were developed by EDC and burdened as described above. No salvage value was assumed for the plant at the end of 20 years.

Depletion. A depletion allowance of $15 \%$ was assumed for the shale oil and an allowance of 14\% was assumed for the minerals.

Depreciation. A plant life of 20 years was assumed and depreciation was taken as double declining balance over 20 years, switching to straight line when the remaining life was 10 years. 
Front-end Costs. Based on data from Tosco, front-end costs of $\$ 115$ million were assumed for plant design and pre-development. This same amount was assumed for each Case, independent of plant size.

Investment Tax Credits. Investment tax credits of $10 \%$ were assumed in the year of capital expenditure.

Taxes. A Federal tax rate of $46 \%$ and a state tax rate of $3 \%$ were assumed. Tax credits were assumed to be used in the year incurred. This essentially assumes that the company building a shale oil plant has other income to which the tax credits can be applied.

Working Capital. Working capital during the construction period is assumed to be $10 \%$ of the current and subsequent year's investment. During the operating life of the plant, working capital was assumed to be sixty days of the operating costs plus G\&A.

Energy Costs. Energy costs of $\$ 1$ per gallon for diesel fuel (1980 prices) were assumed. Electric power was assumed to cost $5 \notin$ per kilowatt-hour, and offgas was assumed to have a value of $\$ 5$ per million Btu. 
ECONOMIC RESULTS

The economic analyses for shale oil, alumina, and soda ash are shown in Tables 6 and 7 for discount rates of 15\% and 10\%, respectively, and the derivation of the cash flows is shown on Exhibits 1 through 3 for the shale oil, alumina, and soda ash facilities, respectively.

Assuming a current crude oil cost of $\$ 35$ per barrel and a discount of about $\$ 10$ per barrel for upgrading, shale oil would be competitive at $\$ 25$ per barrel. At a 15\% ROR, Cases 2 and 4 are economic. Both of these Cases are 50,000 barrels per day plants in rich shale areas. At a $10 \%$ discount rate, all five Cases are economic and Case 4 is the most economic at $\$ 13.8$ per barrel.

Two major assumptions distinguish this study from the recently published Office of Technology Assessment report. The shale oil is assumed to be raw, without hydrotreating or any upgrading. Assuming a current crude oil cost of $\$ 35$ per barrel and a discount of $\$ 10$ per barrel for upgrading, shale oil production in this study would need to cost less than $\$ 25$ per barrel to be currently competitive. In addition, energy costs, and therefore the price of shale oil, were assumed to increase $2 \%$ per year in real terms. This has a major effect on economics as.will be discussed.

Upgrading the soda ash and alumina will require large amounts of energy in the form of heat which would have to be purchased. The returt produces sufficient volumes of lnw BTU gas to meet these requirements and it was assumed in this study that the. low BTU gas would be purchased at the cost of alternate energy, assumed to be the current decontrolled price of crude oil, or $\$ 5$ per million BTU. The sale of offgas improves the economics of shale oil production by $\$ 0.40$ 
to $\$ 1.00$ per barrel in Cases 1 and 2 (the "low mineral" cases) and $\$ 2.90$ to $\$ 4.40$ per barrel in Cases 3,4 and 5 (the "high mineral" cases) as shown below:

\begin{tabular}{lllllll} 
& \multicolumn{4}{c}{ Dollars } & per Barrel \\
\cline { 3 - 6 } Case & $\frac{1}{15 \%}$ & $\frac{2}{1.0}$ & $\frac{3}{2.4}$ & $\frac{4}{2.9}$ & $\frac{5}{2.9}$ & 4.4 \\
$10 \%$ ROR & 1.0 & 0.4 & 2.9 & 3.0 & 4.4
\end{tabular}

Thus, the sale of low BTU gas to the co-product recovery facility can contribute significantly to improving the economics of shale oil.

At $10 \%$, the shale oil economics look attractive in all cases, even with no credits from the sale of offgas. The sole exception is Case 5 (lean shale, rich minerals) with a constant oil price, but energy costs escalating at $2 \%$ per year.

Rich Shale, Lean Mineral Cases

Cases 1 and 2 are the rich shale, lean mineral cases. At $15 \%$, the shale oil economics look marginally attractive for Case 1 and quite attractive for Case 2, the 50,000 barrel per day plant. One reason for this is that no nahcolite recovery unit is required which is a major cost item in the other cases. However, the main purpose of this study was to determine the mineral co-product economics and these are unattractive. Although no market price for alumina currently exists, a 1980 market price of about $\$ 200$ to $\$ 250$ per ton has been estimated, FOB. The cost is $\$ 700-\$ 800$ per ton, so the recovery of co-product minerals in low mineral content deposits exemplified by Cases 1 and 2, are uneconomic. Soda ash is an involuntary by-product of alumina manufacturing and would not be produced unless alumina recovery itself were economic. 
Rich Shale, Rich Mineral Cases

Cases 3 and 4 are the rich shale, rich mineral content cases and they constitute the Base Cases.

At a $15 \%$ rate of return and assuming a $2 \%$ per year escalation in energy costs and the sale of offgas, Case 3, the single unit plant, appears marginally economic at $\$ 26.30$ per barrel while Case 4 , the full size commercial plant, appears to have favorable economics at $\$ 19.50$ per barrel. Without the $2 \%$ per year escalation in real prices the required market threshold price increases to $\$ 33.60$ and $\$ 25.00$ per barrel in Cases 3 and 4 , respectively.

The co-product alumina and soda ash recovery costs are competitive at current market prices or prices estimated for 1990 and later years, as shown below:

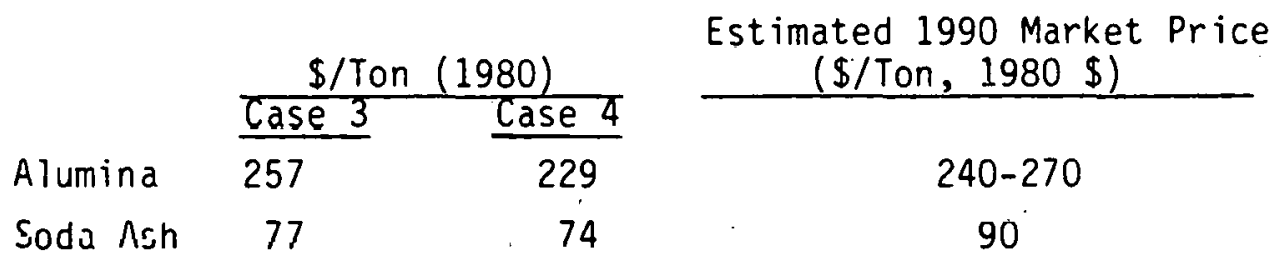

Exhibits 2 and 3 show the economics for: the alumina and soda ash plant in Case 3. These Exhibits show the majur custs that would be incurred and equations for the after-tax annual revenue. By separating the cost and revenue cash. flow in this manner and discounting them separately, the alumina and soda ash prices can be found directly without iteration.

A comparison between the co-product cost for Cases 3 and 4 in the table above shows the potential for economies of scale. Alumina prices decrease $\$ 29$ per ton while soda ash prices only decrease $\$ 3$ per ton. The reason for this is that Direct Operating Costs and Offgas Costs are directily in proportion to the tonnage produced, while 
economies of scale would be reflected in capital changes, other costs and taxes. These "Other" costs constitute $\$ 91$ per ton alumina, but only $\$ 15$ per ton for soda ash as summarized below:

\begin{tabular}{lcc} 
& Aluminum & Soda Ash \\
\cline { 2 - 3 } Direct Operating Cost & 131 & 22 \\
Offgas (Energy) Costs & 35 & 40 \\
Other & $\frac{91}{257}$ & $\frac{15}{77}$ \\
$\quad$ Total &
\end{tabular}

The preceeding table also shows the large costs for energy; $\$ 35$ per ton for alumina and $\$ 40$ per ton for soda ash. Because the low BTU offgas from the shale oil plant may not have a market otherwise., mineral co-products can contribute to the economies of the shale oil plant assuming the minerals can be sold at or above the above costs. Varying the transfer price of offgas can provide considerable flexibility in the pricing of the co-products or be used to improve the economies of the shale oil - assuming that no alternative use of the offgas would be available, as for example, for on-site electricity generation.

Lean Shale, Rich Mineral Case

Case 5 analysis a full scale commercial size facility with lean shale, rich minerals. The shale oil economies in this Case are substantially inferior to Case 4 , but comparable to Case 3 , and even with the sale of the offgas, require a threshold price of $\$ 26.30$, a price that is somewhat higher than the current threshold market price for raw shale oil. 
Because of the large volumes of raw shale mined, the mineral co-product economics reflect economies of scale and are the most favorable of the five cases. The manufacturing cost of alumina drops to $\$ 205$ per ton and the cost of soda ash to $\$ 71$ per ton, well below current market prices. the major finding is, therefore, that the integrated plant producing shale oil, alumina and soda ash, is economic and that the recovery of co-products can economically make feasible the vast bulk of the lower grade shale ore in the Northern Piceance Basin. 
Table 1

CASE 1 Burdened Costs

(Dollars in Millions)

Facility

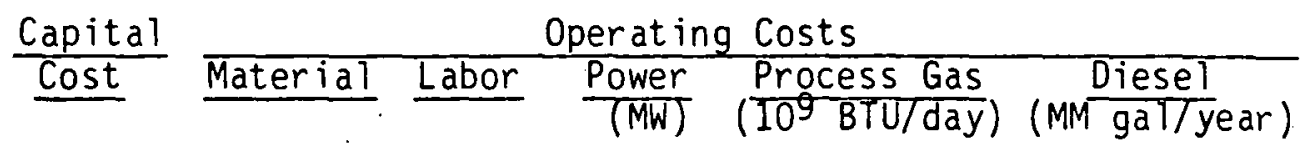

Mining/Primary

Crushing

Nahcolite Recovery

Unit

Retort/0il and Gas

handling

Process and Plant $\mathrm{H}_{2} \mathrm{O}$ Facilities

Slurry Disposal General Plant

Facilities Total

ALSAR Plant

35.2

0.2

21.3

7.2

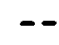

1.1

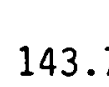

4.7

2.1

13.1

198.8

18.4

6.2

0.4

1.1

2.4

3.6

$\frac{17.2}{37.3}$

$\frac{2.8}{36.3}$

$5.7^{\bullet} 11.3$

Crushing \& Leaching

Al $(\mathrm{OH})_{3}$ Precipitation and Washing

Al $(\mathrm{OH})_{3}$ Calcination $\mathrm{Na}_{2} \mathrm{CO}_{3}$ Crystalization and Filtration

$\mathrm{Na}_{2} \mathrm{CO}_{3}$ Dehydration Total
3.3

29.8

2.9

3.6

0.2

0.2

0.6

0.5

0.6

0.3

0.6

1.2

0.7

$\frac{1.0}{43.9}$

$\frac{0.2}{8.2}$

$\frac{0.1}{13.0}$

$\overline{4.3}$ $\frac{0.6}{1.4}$

$\ddot{1.1}$

17 Does not include recycle gas to retort. 


\section{Table 2}

CASE 2 Burdened Cost's

(Dollars in Millions)

Facility

Mining/Primary

Crushing

Nahcolite Recovery

Unit

Retort/0il and Gas

hand ling

Process and Plant.

$\mathrm{H}_{2} \mathrm{O}$ Facilities

Slurry Disposal

General Plant

Facilities

Total

ALSAR Plant

Retorted Shale

Crushing \& Leaching

$\mathrm{Al}(\mathrm{OH})_{3}$ Precipitation and Washing

$\mathrm{Al} .(\mathrm{OH})_{3}$ Calcination

$\mathrm{Na}_{2} \mathrm{CO}_{3}$ Crystalization

and Filtration

$\mathrm{Na}_{2} \mathrm{CO}_{3}$ Dehydration Total $\frac{\text { Capital }}{\text { Cost }}$

84.7

$\begin{array}{ll}77.5 & 23.6\end{array}$

452.0

17.2

8.5

28.9

$5 \overline{91.3}$

94.9

3.8

12.2

7.7

1.7

120.3

\section{Material
0.6}

61.2

1.4

4.3

9.0

14.5

$7 \frac{3.7}{1.2}$

$\frac{6.3}{128.9} \quad 7 \frac{2.9}{3.1}$

4.7

12.4

29.5

0.2

--

$\frac{1.5}{4.3}$

$\frac{--}{4.5}$

\section{$9.9 \quad 21.0 \quad 48.5$}

0.3

1.1

0.8

2.2

0.7

0.9

1.6

0.8

0.8

$\frac{0.2}{12.3}$

$\frac{0.3}{25.9}$

$\frac{1.0}{51.9}$
$-$

2.611

Operating Costs

(MM $\frac{\text { Diesel }}{\text { gal/year) }}$

\section{5}
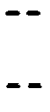

--

If Does not include recycle gas to retort. 
Table 3

CASE 3 Burdened Costs (Dollars in Millions) Capital Cost Material Labor $\frac{\text { Power }}{\text { (MW) }} \frac{\text { Process Gas }}{\left(10^{9} \text { BTU/day) }\right.}$ (MM Dals/year) Operating Costs

\section{Facility}

Mining/Primary Crushing

Nahcolite Recovery Unit

Retort/0il and Gas handling

Process and Plant $\mathrm{H}_{2} \mathrm{O}$ Facilities Slurry Disposal General Plant Facilities

Total

\begin{tabular}{|c|c|c|c|c|c|}
\hline 38.0 & 0.2 & 21.6 & 8.2 & -- & \\
\hline 42.3 & 2.9 & 4.0 & 2.4 & 1.3 & \\
\hline 143.3 & 17.6 & 6.1 & 7.5 & 0.2 & \\
\hline $\begin{array}{l}5.0 \\
2.1\end{array}$ & $\begin{array}{l}0.5 \\
1.1\end{array}$ & $\begin{array}{l}2.8 \\
4.9\end{array}$ & $\begin{array}{l}1.4 \\
3.6\end{array}$ & -- & \\
\hline 13.1 & 1.7 & $\underline{2.9}$ & $\underline{1.3}$ & 0.7 & \\
\hline $2 \overline{243.8}$ & $2 \overline{24.0}$ & $4 \overline{2.3}$ & $2 \overline{24.4}$ & $\overline{2.2}$ & \\
\hline 33.4 & 3.3 & 6.7 & 13.5 & -- & \\
\hline $\begin{array}{r}5.7 \\
20.4\end{array}$ & $\begin{array}{l}0.4 \\
1.9\end{array}$ & $\begin{array}{l}1.2 \\
3.5\end{array}$ & $\begin{array}{l}1.2 \\
1.7\end{array}$ & $3 . \overline{-}$ & \\
\hline $\begin{array}{r}15.6 \\
\frac{4.9}{80.0}\end{array}$ & $\begin{array}{r}1.6 \\
0.9 \\
8.1\end{array}$ & $\begin{array}{r}3.0 \\
1.1 \\
15.5\end{array}$ & $\begin{array}{r}1.7 \\
0.8 \\
1 \frac{0.9}{8.9}\end{array}$ & $\begin{array}{r}6.2 \\
0.8 \\
10.1\end{array}$ & $\approx$ \\
\hline
\end{tabular}

ALSAR Plant

Retorted Shale

Crushing \& Leaching Al $(\mathrm{OH})_{3}$ Precipitation and Washing $\mathrm{Al}(\mathrm{OH})_{3}$ Calcination $\mathrm{Na}_{2} \mathrm{CO}_{3}$ Crystalization and Filtration $\mathrm{Na}_{2} \mathrm{CO}_{3}$ Dehydration Total

Operating Costs
Material Labor
$\frac{\text { Power }}{\text { (MW) }} \frac{\text { Process Gas }}{\left(10^{9} \text { BTU/day }\right)}$ (MM Dals/year)




\section{Table 4 \\ CASE 4 Burdened Costs \\ (Dollars in Millions)}

Facility

$\frac{\text { Capital }}{\frac{\text { Operating Costs }}{\text { Costs }}} \frac{\text { Material Labor }}{\frac{\text { Power }}{\text { (MW) }} \frac{\text { Process Gas }}{\left(10^{9} \text { BTU/day) }\right.} \text { (MM } \frac{\text { Diesel }}{\text { gal/year) }}}$

\begin{tabular}{|c|c|c|c|c|c|c|}
\hline $\begin{array}{l}\text { Mining/Primary } \\
\text { Crushing }\end{array}$ & 75.4 & 0.5 & 59.9 & 21.8 & -- & 4.2 \\
\hline Nahcolite Recovery & & & & & & \\
\hline $\begin{array}{l}\text { Unit } \\
\text { Retort/0il and.Gas }\end{array}$ & 118.9 & 7.6 & 9.3 & 7.0 & 3.8 & -- \\
\hline $\begin{array}{l}\text { handling } \\
\text { Process and Plant }\end{array}$ & 357.0 & 46.0 & 17.4 & 21.3 & 2.311 & -- \\
\hline $\mathrm{H}_{2} \mathrm{O}$ Facilities & 13.8 & 1.2 & 7.9 & 4.2 & -- & -- \\
\hline $\begin{array}{l}\text { Slurry Disposal } \\
\text { General Plant }\end{array}$ & 5.7 & 3.1 & 13.4 & 10.8 & -- & -- \\
\hline Facilities & 25.3 & 4.2 & 7.6 & 3.9 & 2.2 & $=$ \\
\hline $\begin{array}{c}\text { Total } \\
\text { ALSAR Plant }\end{array}$ & 596.1 & 62.6 & 115.5 & 69.0 & 8.3 & 4.2 \\
\hline $\begin{array}{l}\text { Retorted Shale } \\
\text { Crushing \& Leaching } \\
\text { Al(OH })_{3} \text { Precipitation }\end{array}$ & 81.8 & 7.8 & 16.2 & 38.4 & -- & -- \\
\hline $\begin{array}{l}\text { and Washing } \\
\mathrm{Al}(\mathrm{OH})_{3} \text { Calcination } \\
\mathrm{Na}_{3} \mathrm{CO}_{3} \text { Crystalization }\end{array}$ & $\begin{array}{l}13.8 \\
57.1\end{array}$ & $\begin{array}{l}1.0 \\
5.2\end{array}$ & $\begin{array}{r}3.6 \\
11.1\end{array}$ & $\begin{array}{l}3.6 \\
5.0\end{array}$ & $9 . \overline{-}$ & $=-$ \\
\hline $\begin{array}{l}\text { and } \mathrm{Fi} 1 \text { tration } \\
\mathrm{Na}_{2} \mathrm{CO}_{3} \text { Dehydration }\end{array}$ & $\begin{array}{l}41.7 \\
11.4 \\
\end{array}$ & $\begin{array}{l}4.7 \\
0.9 \\
\end{array}$ & $\begin{array}{l}8.7 \\
3.2 \\
\end{array}$ & $\begin{array}{l}5.2 \\
2.3 \\
\end{array}$ & $\begin{array}{r}18.5 \\
2.3 \\
\end{array}$ & -- \\
\hline Total & 205.8 & 19.6 & 42.8 & 54.5 & 30.4 & 0 \\
\hline
\end{tabular}

If Does not include recycle gas to retort. 
Table 5

CASE 5 Burdened Costs

Facility

(Dollars in Millions)

Capital

Operating Costs

Cost Material Labor $\frac{\text { Power }}{\text { (MW) }}\left(10^{\frac{\text { Process BTU/day })}{\text { BM }}} \frac{\text { Diesel }}{\mathrm{gals} / \mathrm{gr})}\right.$.

Mining/Primary

Crushing

Nahcolite Recovery

Unit

Retort $/ 0 \mathrm{il}$ and Gas

hand 7 ing

Process and Plant

$\mathrm{H}_{2} \mathrm{O}$ Facilities

Slurry Disposal

General Plant

Facilities

Total

ALSAR Plant

Retorted Shale

Crushing \& Leaching

Al $(\mathrm{OH})_{3}$ Precipitation and Washing

$\mathrm{Al}(\mathrm{OH})_{3}$ Calcination

$\mathrm{Na}_{2} \mathrm{CO}_{3}$ Crystalization

132.7

0.8

$108.3 \quad 33.1$

6.9

184.2

11.5

14.6

11.4

6.2

540.5

71.8

$25.1 \quad 37.0$

3.411

20.9

1.7

$11.2 \quad 7.0$

9.0

4.8

$20.8 \quad 18.0$

$\frac{32.8}{920.1}$

$\frac{6.4}{97.0} \quad \frac{12.2}{192.2} \quad 11 \frac{6.5}{3.0}$

$\frac{3.7}{13.3}$

$\frac{--}{6.9}$

and Filtration

$\mathrm{Na}_{2} \mathrm{CO}_{3}$ Dehydration Total

111.8

11.6

$39.9 \quad 64.1$

20.6

\section{4}

4.6

5.8

91.7

7.6

15.7

8.3

16.0

48.9

6.8

14.7

8.8

$\frac{5.2}{80.1} \quad \frac{3.8}{90.8}$

30.9

$\frac{17.7}{290.7}$

$\frac{1.3}{28.7}$

$\frac{3.8}{50.7}$

$\frac{-}{0}$

IT Does not include recycle gas to retort. 


\section{$\underline{\text { Table } 6}$}

$\frac{\text { Shale Co-Product Study }}{\text { Economic Results at } 15 \% \text { Rate of Return }}$
(\$/Bbl. or $\$ /$ ton)
Case $\quad \frac{\text { Rich Shale, }}{1} \quad \begin{aligned} & \text { Rich Shale, } \\ & \text { Lean Minerals }\end{aligned}$

Shale 0il (with $\$ 5$ per MMBTU Credit)

Escalating Price

$+2 \%$ per year

Escalating Price

w/o offgas credits

Constant Price

Alumina

with offgas costs $\quad 1028$

$w / 0$ offgas costs

Soda Ash

with urfyas coists

$w / 0$ offgas costs

26.1

27.1

33.5

990
19.8

26.3

19.5

26.3

20.2 .

29.2

22.4

30.7

25.4

33.6

25.0

33.4

887

257

229

205

849

222

194

170
339
116

58
77

74

71

151

37

34

31 


\section{Table 7}

Shale Co-Product Study

Economic Results at 10\% Rate of Return

$(\$ / B b 1$. or $\$ /$ ton $)$

$\begin{array}{llll}\text { Rich Shale, } & \begin{array}{l}\text { Rich Shale, } \\ \text { Lean Minerals }\end{array} & \begin{array}{l}\text { Lean Shale, } \\ \text { Rich minerals } \\ \text { Case }\end{array} & \end{array}$

Shale 0 il (with $\$ 5$ per MMBTU Credit)

Escalating Price

$+2 \%$ per year

Escalating Price w/o

offgas energy credits

Constant Price

Alumina

with offgas energy cost 89

w/o energy

offgas cost

853

Soda Ash

with offgas energy cost

w/o offgas

energy cost

18.5

19.5

24.3

313

123
20.0

776

227

203

187

743

19.1

167

151

109

72

70

68

49

31

29

27 


\section{Exhibit 1}

CASE 3

Shate 0il Plant Economics

(Aillions of Dollars)

\begin{tabular}{|c|c|c|c|c|c|c|c|c|c|c|c|c|c|c|}
\hline \multirow{2}{*}{$\begin{array}{c}\text { Year } \\
\text { Annual Production, } \\
10^{6} \text { tons mined } \\
0 i 1,10^{6} \text { barrels }\end{array}$} & 1 & 2 & 3 & 4 & 5 & 6 & 7 & 8 & 9 & 10 & 15 & 20 & 25 & 28 \\
\hline & $=-$ & -- & -- & $\begin{array}{l}-- \\
--\end{array}$ & $=$ & -- & $\begin{array}{l}2.8 \\
1.7\end{array}$ & $\begin{array}{l}6.4 \\
4.0\end{array}$ & $\begin{array}{l}9.2 \\
5.7\end{array}$ & $\begin{array}{l}9.2 \\
5.7\end{array}$ & $\begin{array}{l}9.2 \\
5.7\end{array}$ & $\begin{array}{r}9.2 \\
5.7\end{array}$ & $\begin{array}{l}9.2 \\
5.7\end{array}$ & $\begin{array}{l}9.2 \\
5.7\end{array}$ \\
\hline \multirow{4}{*}{$\begin{array}{l}\text { Rcyalties } \\
\text { Operating Cost } \\
\text { Diese } 1 \\
\text { (1.3:106 gal) } \\
\text { Power }(24.3 \mathrm{MW}) \\
\text { G\&A } \\
\text { Depreciation } \\
\text { Net Cost Before } \\
\text { Tax Effects } \\
\text { Federal Tax } \\
\text { State Tax } \\
\text { Net Cost After } \\
\text { Tax Effects }\end{array}$} & -- & -- & -- & -- & -- & -- & $\begin{array}{r}0.3 \\
19.7\end{array}$ & $\begin{array}{r}0.8 \\
41.0\end{array}$ & $\begin{array}{r}1.2 \\
65.7\end{array}$ & $\begin{array}{r}1.2 \\
65.7\end{array}$ & $\begin{array}{r}1.2 \\
65.7\end{array}$ & $\begin{array}{r}1.2 \\
65.7\end{array}$ & $\begin{array}{r}1.2 \\
65.7\end{array}$ & $\begin{array}{r}1.2 \\
65.7\end{array}$ \\
\hline & $\begin{array}{l}-- \\
-- \\
2.4 \\
2.4 \\
\end{array}$ & $\begin{array}{l}-- \\
-- \\
4.9 \\
7.1 \\
\end{array}$ & $\begin{array}{c}-- \\
-- \\
4.9 \\
11.3 \\
\end{array}$ & $\begin{array}{c}-- \\
-- \\
4.9 \\
15.0 \\
\end{array}$ & $\begin{array}{r}-- \\
4.9 \\
18.4 \\
\end{array}$ & $\begin{array}{l}-- \\
-- \\
2.4 \\
19.0 \\
\end{array}$ & $\begin{array}{r}0.4 \\
3.6 \\
3.0 \\
17.1 \\
\end{array}$ & $\begin{array}{r}1.0 \\
8.6 \\
6.9 \\
15.4 \\
\end{array}$ & $\begin{array}{r}1.5 \\
12.5 \\
9.9 \\
13.9 \\
\end{array}$ & $\begin{array}{r}1.5 \\
12.7 \\
9.9 \\
12.5 \\
\end{array}$ & $\begin{array}{r}1.7 \\
14.0 \\
9.9 \\
7.4 \\
\end{array}$ & $\begin{array}{r}1.9 \\
15.5 \\
9.9 \\
4.3 \\
\end{array}$ & $\begin{array}{r}2.1 \\
17.1 \\
9.9 \\
4.3 \\
\end{array}$ & $\begin{array}{r}2.2 \\
18.2 \\
9.9 \\
4.3 \\
\end{array}$ \\
\hline & $\begin{array}{c}(4.8) \\
2.2 \\
0.1 \\
\end{array}$ & $\begin{array}{c}(12.0) \\
5.5 \\
0.2 \\
\end{array}$ & $\begin{array}{c}(16.2) \\
7.5 \\
0.3 \\
\end{array}$ & $\begin{array}{c}(19.9) \\
9.2 \\
0.3 \\
\end{array}$ & $\begin{array}{r}(23.3) \\
10.7 \\
0.4 \\
\end{array}$ & $\begin{array}{c}(21.4) \\
9.8 \\
0.9 \\
\end{array}$ & $\begin{array}{c}(44.1) \\
20.3 \\
0.7 \\
\end{array}$ & $\begin{array}{r}73.7 \\
33.9 \\
1.6 \\
\end{array}$ & $\begin{array}{c}(104.7) \\
48.2 \\
\cdot \quad 1.7 \\
\end{array}$ & $\begin{array}{c}(103.5) \\
47.5 \\
1.7 \\
\end{array}$ & $\begin{array}{c}(99.9) \\
46.0 \\
1.6 \\
\end{array}$ & $\begin{array}{c}(98.5) \\
45.3 \\
1.6 \\
\end{array}$ & $\begin{array}{c}(100.3) \\
46.1 \\
1.6 \\
\end{array}$ & $\begin{array}{r}(101.5) \\
46.7 \\
1.6 \\
\end{array}$ \\
\hline & $(2.5)$ & $(6.3)$ & $(8.4)$ & $(10.4)$ & $\{12.2\}$ & $(10.7)$ & $(23.1)$ & $(38.2)$ & $(54.8)$ & $(54.3)$ & $(52.3)$ & $(51.5)$ & $(52.6)$ & $(53.2)$ \\
\hline Inves tment & $(24.4)$ & $(48.8)$ & $(48.3)$ & $(48.8)$ & $(48.8)$ & $(24.0)$ & -- & - & -- & -- & - & - & - & - \\
\hline Annual Revenue $=$ & $\begin{array}{l}\text { [Produ } \\
\text { Tax] } \\
\text { Produc }\end{array}$ & oleti & Price & & eranice & & eplet & + of & $\mathrm{SCr}$ & $s][1$ & Federal & Tax ] & - State & \\
\hline
\end{tabular}

The alumina and the soda ash plant use 10.1 - $10^{9}$ BTU/day of offgas. 


\section{Exhibit 2}

\section{CASE 3}

Alumina Plant Economics

$\frac{\text { Alumina Plant Economics }}{\text { (Millions of Dollars) }}$

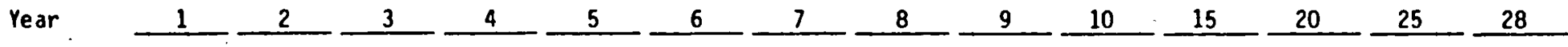

Annual Production, $10^{6}$ tons

Operating Cost Power (16.4 MW)

G\&A

Depreciation

Net Cost Before Tax Effects Federal Tax

St ate Tax

Net Cost After Tax Effects

Investment

ITC

Deprectation

Working Capital

Cash Requirements

\begin{tabular}{|c|c|c|c|c|c|c|c|c|c|c|c|c|c|}
\hline- & -- & -- & -- & -- & - & 0.1 & 0.1 & 0.2 & 0.2 & 0.2 & 0.2 & 0.2 & 0.2 \\
\hline $\begin{array}{l}-- \\
-- \\
0.3 \\
0.3 \\
\end{array}$ & $\begin{array}{l}-- \\
-- \\
0.3 \\
0.6 \\
\end{array}$ & $\begin{array}{l}-- \\
-\overline{0.3} \\
0.8 \\
\end{array}$ & \begin{tabular}{l}
-- \\
\hdashline 1.8 \\
2.5 \\
\end{tabular} & $\begin{array}{r}1.8 \\
4.1 \\
\end{array}$ & $\begin{array}{l}-- \\
-- \\
1.5 \\
5.1 \\
\end{array}$ & & $\begin{array}{l}1 \\
4\end{array}$ & $\begin{array}{l}2 \\
3 \\
\end{array}$ & $\begin{array}{l}2 \\
3 \\
\end{array}$ & $\begin{array}{l}2 \\
1\end{array}$ & & 1 & $\begin{array}{r}16.7 \\
12.2\end{array}$ \\
\hline $\begin{array}{c}(0.6) \\
0.3 \\
-- \\
\end{array}$ & $\begin{array}{c}(0.9) \\
0.4 \\
-- \\
\end{array}$ & $\begin{array}{c}(1.1) \\
0.5 \\
-- \\
\end{array}$ & $\begin{array}{c}(4.3) \\
2.0 \\
0.1 \\
\end{array}$ & $\begin{array}{c}(5.9) \\
2.7 \\
0.1 \\
\end{array}$ & $\begin{array}{c}(6.6) \\
3.0 \\
0.1 \\
\end{array}$ & $\begin{array}{r}13 . \\
6 . \\
0 .\end{array}$ & $\begin{array}{r}10 \\
0 \\
\end{array}$ & $\begin{array}{r}31 \\
14 \\
0 \\
\end{array}$ & $\begin{array}{r}130 \\
14 \\
0 \\
\end{array}$ & $\begin{array}{r}130 \\
14 \\
0 \\
\end{array}$ & $\begin{array}{r}(30.7) \\
14.1 \\
0.5 \\
\end{array}$ & $\begin{array}{r}14 \\
0 \\
\end{array}$ & $\begin{array}{r}14 \\
0\end{array}$ \\
\hline$(0.3)$ & $(0.5)$ & $(0.6)$ & $(2.2)$ & $(3.1)$ & $(3.5)$ & $(6.9)$ & $(12.3)$ & $(16.2)$ & $(16.1)$ & $(15$ & $(16.1)$ & $(16$ & \\
\hline$(3.0)$ & $(3.0)$ & $(3.0)$ & $(17.9)$ & $(17.9)$ & $(14.7)$ & -- & $\cdots$ & -. & $\cdots$ & 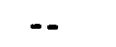 & - & - & 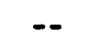 \\
\hline $\begin{array}{l}0.3 \\
0.3 \\
\left\{\begin{array}{l}0.6 \\
(3.3)\end{array}\right.\end{array}$ & $\begin{array}{l}0.3 \\
0.6 \\
-- \\
(2.6)\end{array}$ & $\begin{array}{l}0.3 \\
0.8 \\
(1.5) \\
4.01\end{array}$ & $\begin{array}{r}1.8 \\
2.5 \\
(1.5) \\
(17.3)\end{array}$ & $\begin{array}{r}1.8 \\
4.1 \\
(0.3) \\
(14.8)\end{array}$ & $\begin{array}{r}1.5 \\
5.1 \\
(1.8) \\
(9.8)\end{array}$ & $\begin{array}{c}5.0 \\
(0.5) \\
(1.4)\end{array}$ & $\begin{array}{c}-- \\
(1.2 \\
(1.2) \\
(9.3)\end{array}$ & $\begin{array}{r}3.4 \\
(1.0) \\
(13.8)\end{array}$ & $\begin{array}{c}3.0 \\
\cdots \\
\overline{T 13.11}\end{array}$ & $\begin{array}{c}\overline{1.8} \\
-\overline{(14.1 T}\end{array}$ & $\begin{array}{c}-\overline{1.1} \\
\overline{(14.9)}\end{array}$ & $\begin{array}{l}-i \\
-- \\
\text { (15.6) }\end{array}$ & $\begin{array}{l}1.1 \\
3.2 \\
(12.8)\end{array}$ \\
\hline
\end{tabular}

Annual Revenue $=$ [Production - Alumina Price - Depletion-0ffáas Cost ] $(1$ - Federal Tax) (1-State Tax) + Depletion Production. Alumina Price 0.590 - Offgas Cost 0.524

The alumina facilities use $3.2 \cdot 10^{9}$ BTU/day of offyas. 


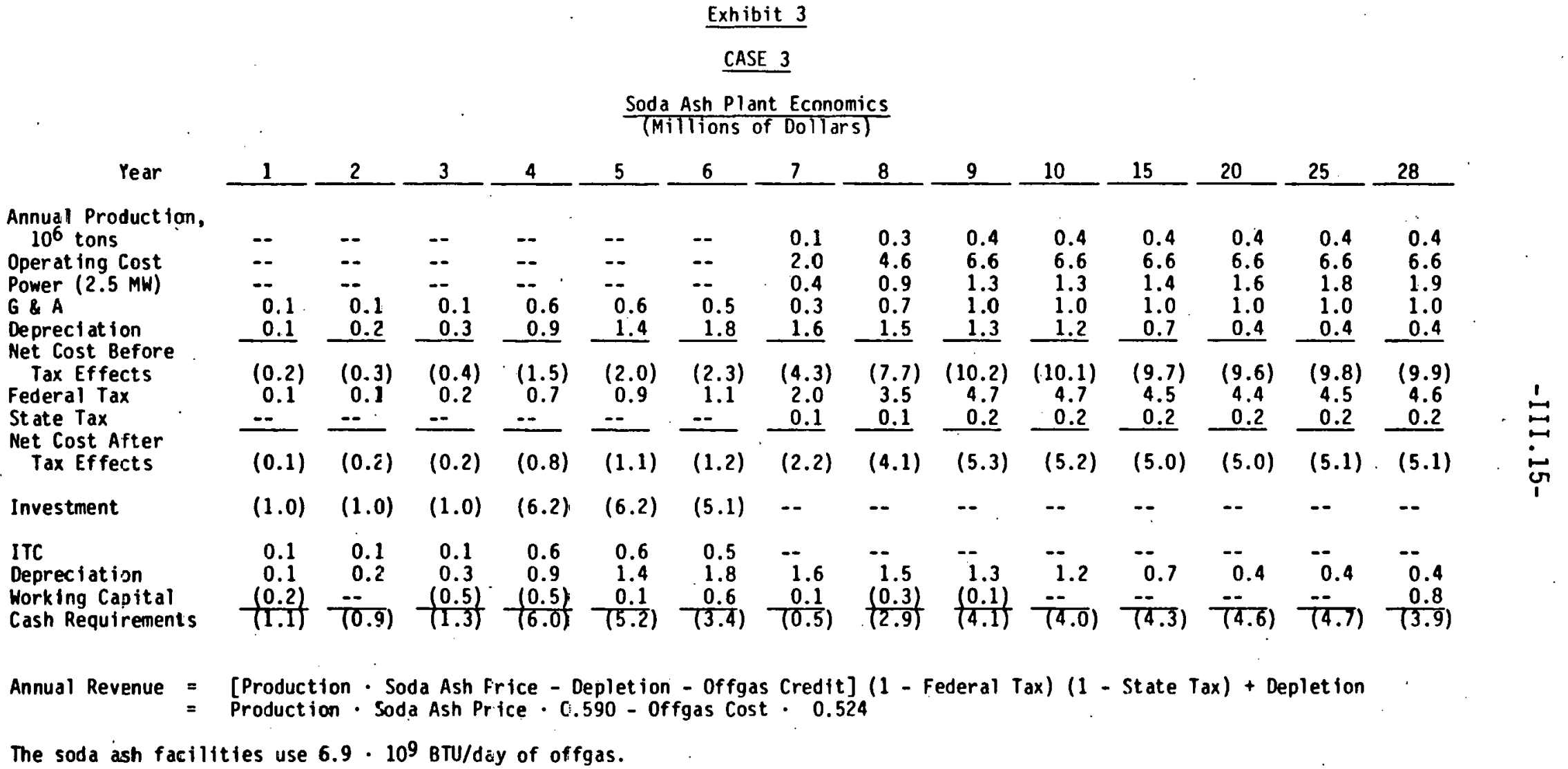


APPENDIX 3

OIL SHALE MINERAL MARKET POTENTIAL 
ABSTRACT

$0 i]$ shale mineral resources in the Western United States represent a major potential alternative to petroleum imports if recovery economics can be made competitive with primary hydrocarbon processes.

The shale oil recoverable from the mineral matrix is approximately $10 \%$ by weight of the mined ore. As a result, large volumes of ore must be processed in order to obtain sufficient production to afford the high capital investment and operating costs of shale oil production.

Certain oil shale deposits are composed of dawsonite, a mineral consisting primarily of alumina, and nahcolite, a naturally occurring sodiurn bicarbonate. It has been postulated that recovery of the mineral values from the ore, in addition to the shale oil, could confer sufficient economic advantage to use of oil shale to significantly accelerate its exploitation as a domestic energy source.

One of the principal constraints upon full scale development of mineral recovery as co-products with shale $0 i l$ is uncertainty about the ability of markets to absorb such large volumes of involuntary production.

This study examines the market economics for alumina and soda ash, the primary commercial products likely to result from mineral recovery, and the major factors affecting future demand as well as competitive products.

The study fundings indicate that alumina recovery, if qualitatively equivalent to existing sources, would be competitive with existing supplies, and would make a significant contribution toward a favorable balance of payments. In addition it is possible that existence of a large domestic supply would result in price pressure on imported material.

Supplies of soda ash from both natural and synthetic (Solvay Process) sources are believed to be adequate domestically for the foreseeable future, but foreign Solvay process plants are believed to be vulnerable because of their high labor and energy costs. Eastern Europe has emerged as a major producer and exporter of soda ash in order to earn foreign tax credits, with its primary market Western Europe. 


\section{LIST OF FIGURES}

Figure 1 - World Aluminum Producing Nations

Figure 2 - World Alumina Producing Nations

Figure 3 - U. S. Aluminum and Alumina Plant Locations

Figure 4 - World Soda Ash Producers

Figure 5 - U. S. Soda Ash and Glass Producing Plants

Figure 6 - Caustic and Selected Chemicals

Figure 7 - Equivalent Values for Selected Products Containing Sodium 0xide 


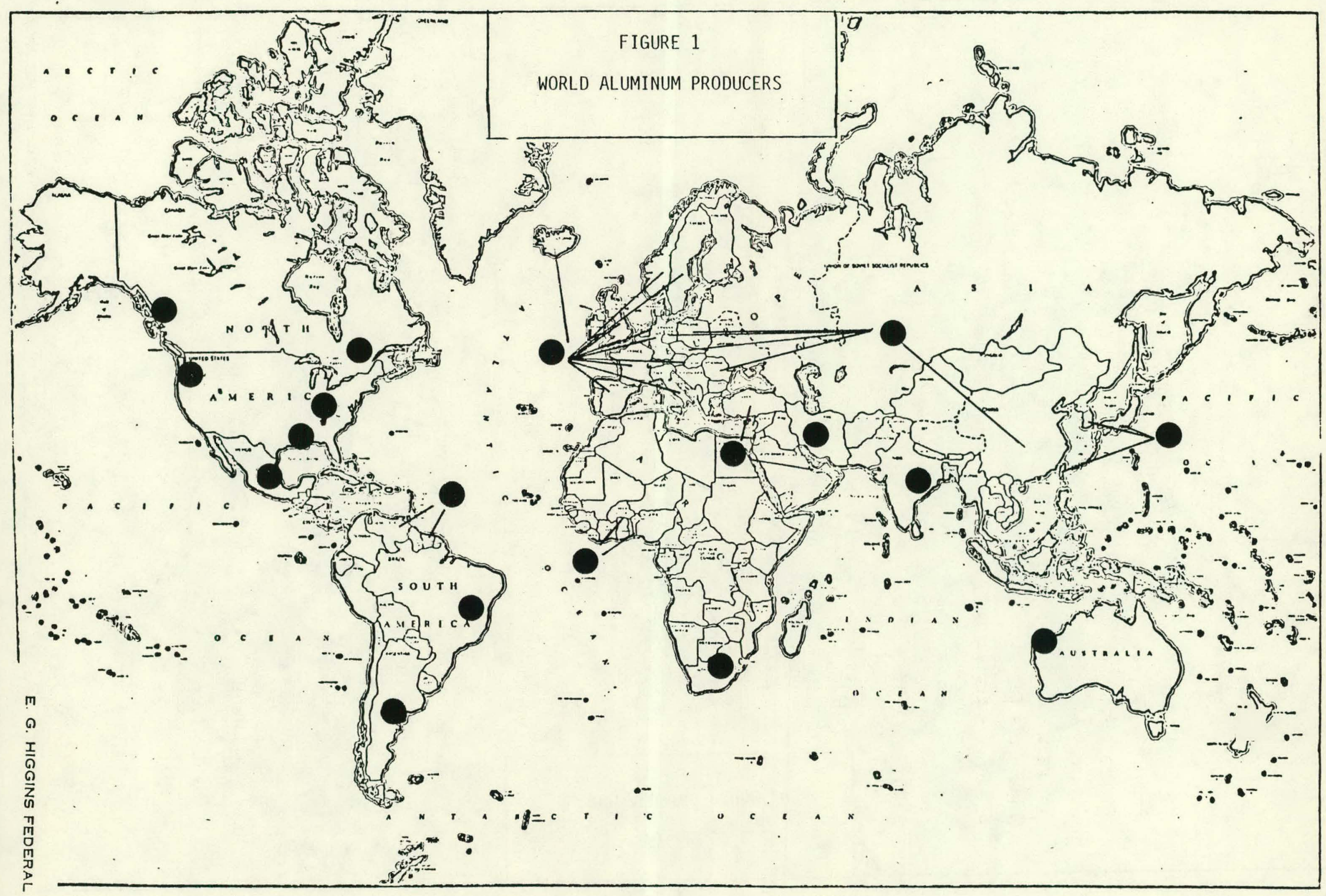




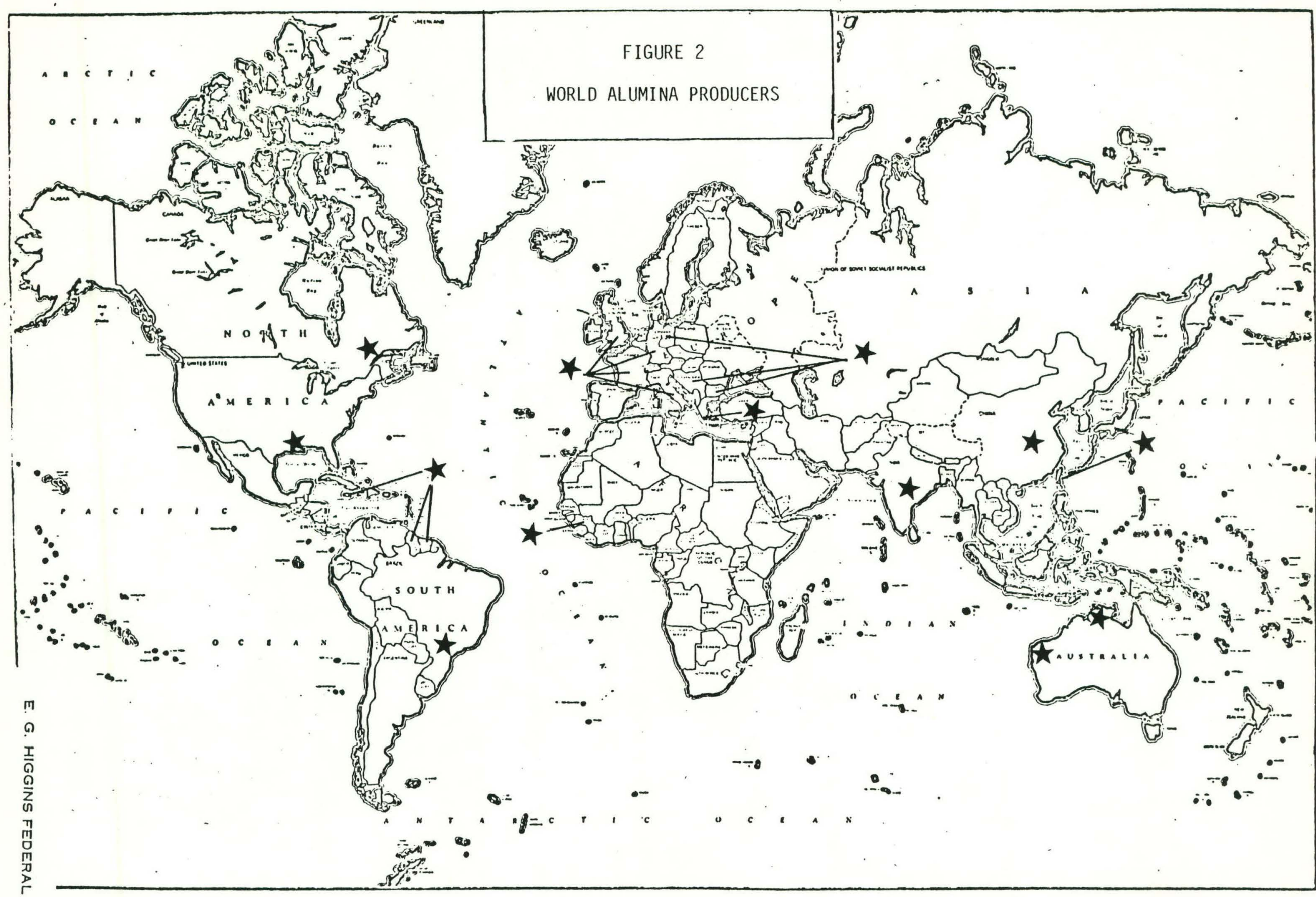


FIGURE 3

ALAOKA

U. S. ALUMINA AND ALUMINUM PLANT LOCATIONS

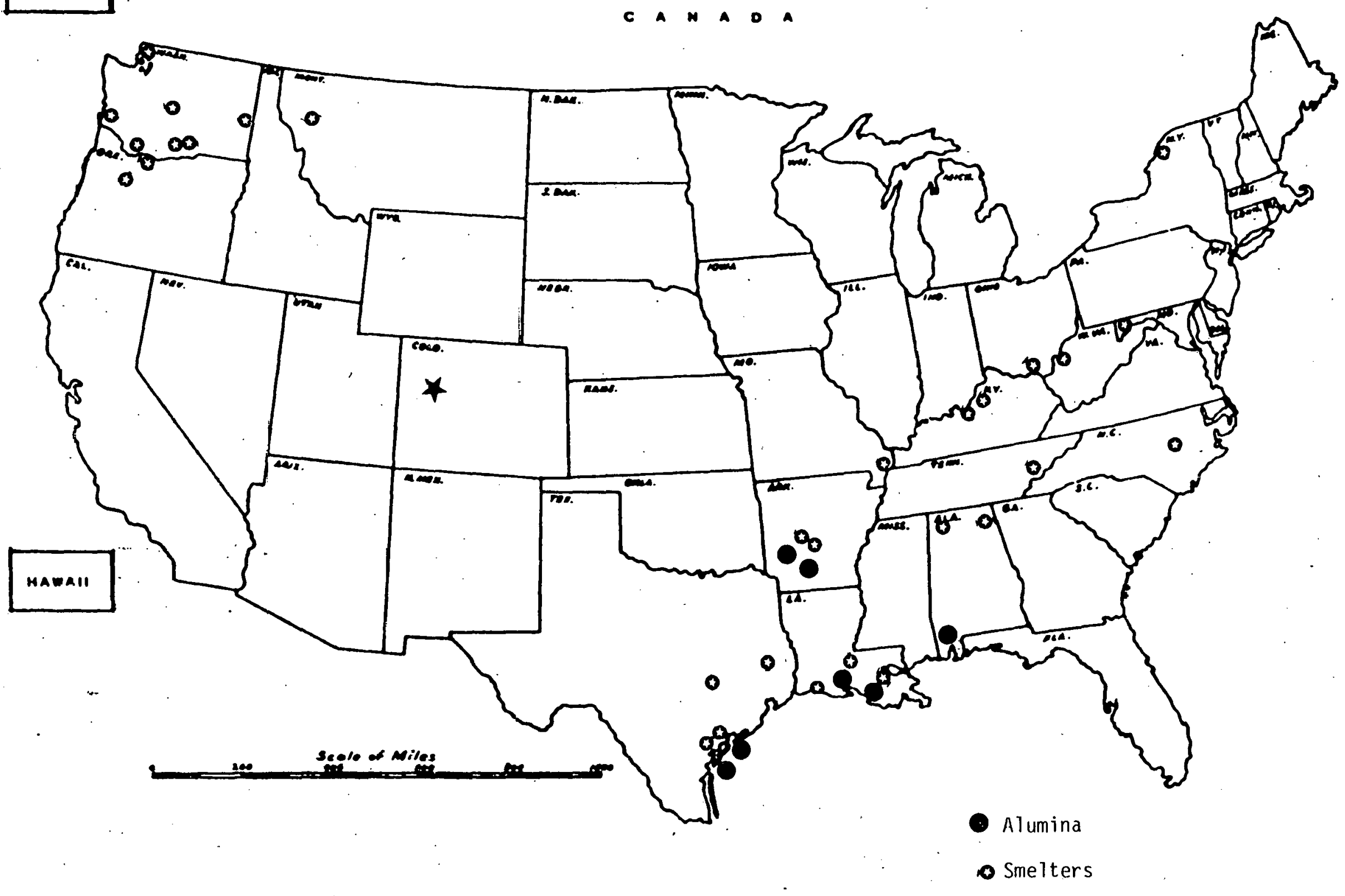




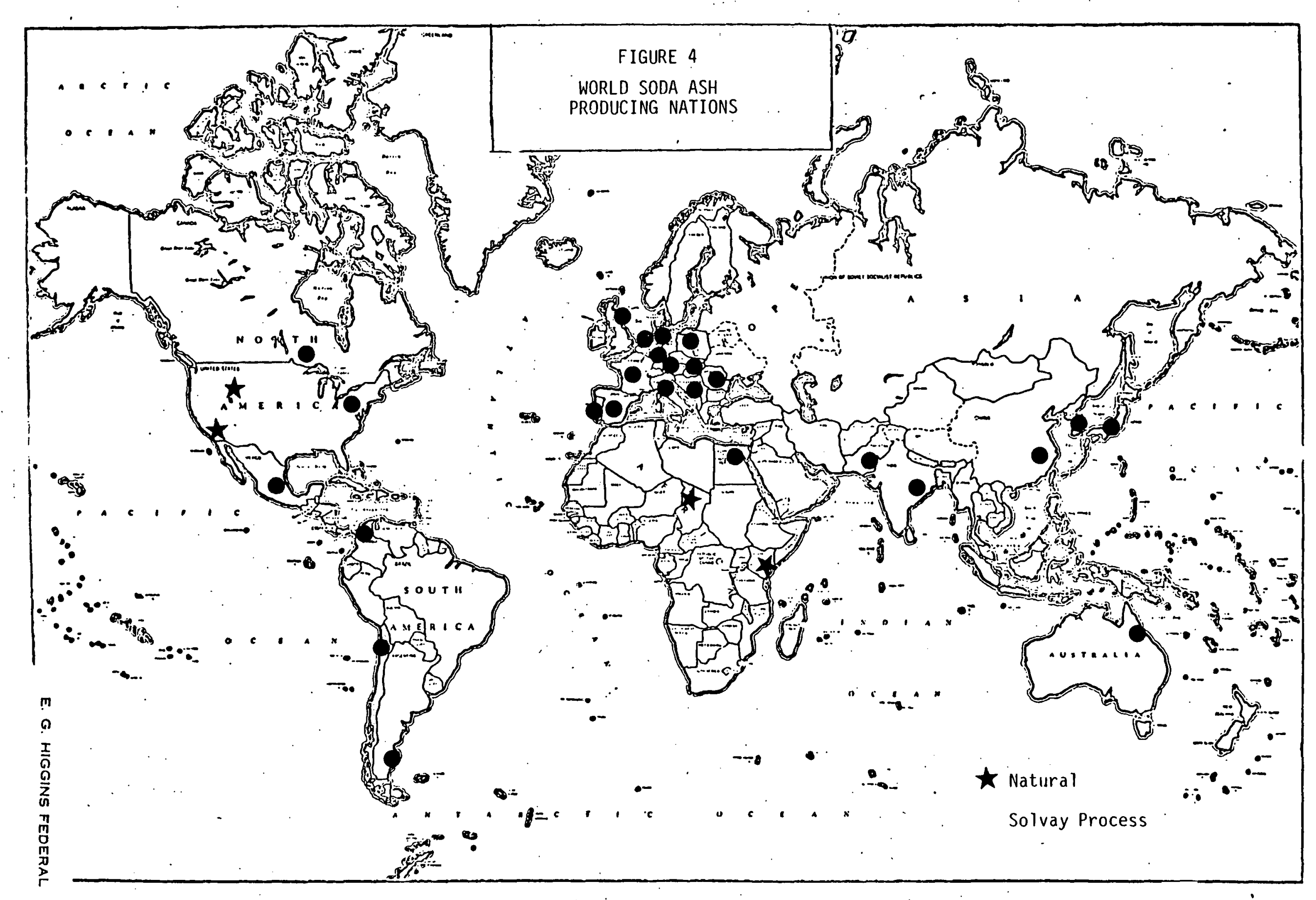


FIGURE 5

Alaska

U.S. SODA ASH AND GLASS PLANTS

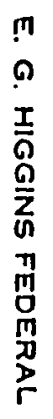

CA $A$ DA

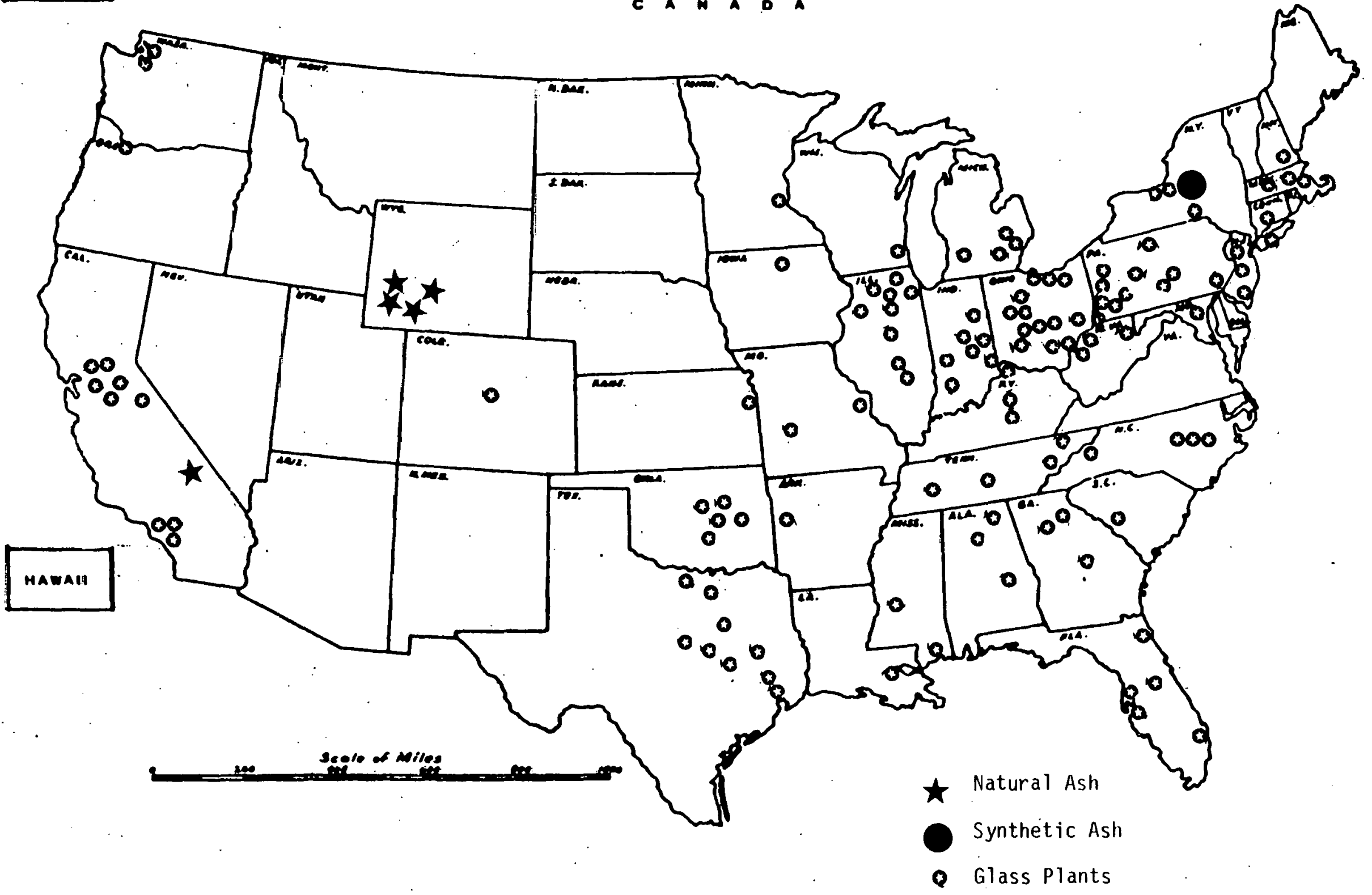


FIGURE 6

\section{Alaska}

U. S. CAUSTIC, CHLORINE AND SELECTED CHEMICAL PLANTS

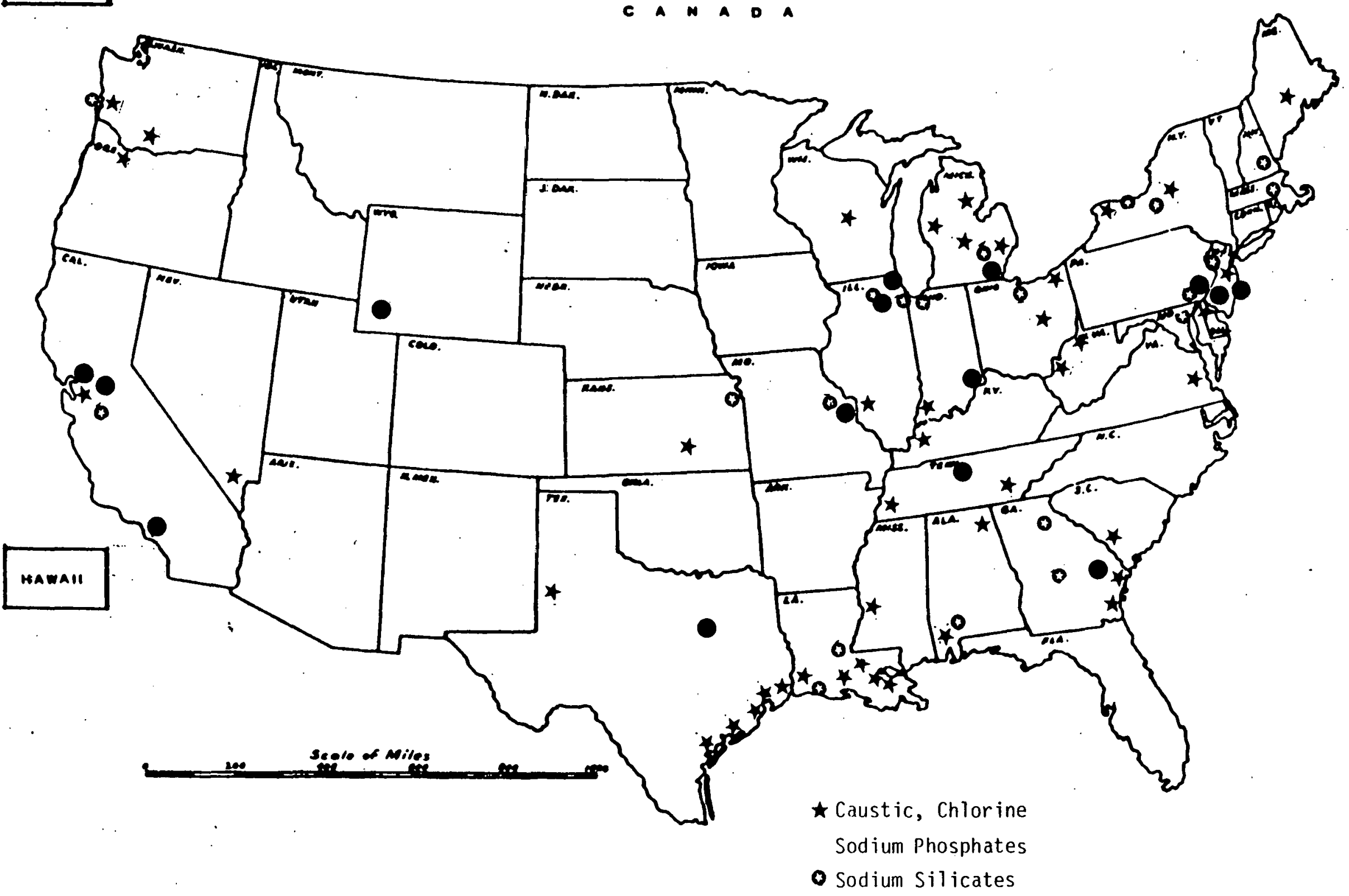


PRICE EQUIVALENCIES FOR SODIUM OXIDE AND SELECTED DERIVATIVES

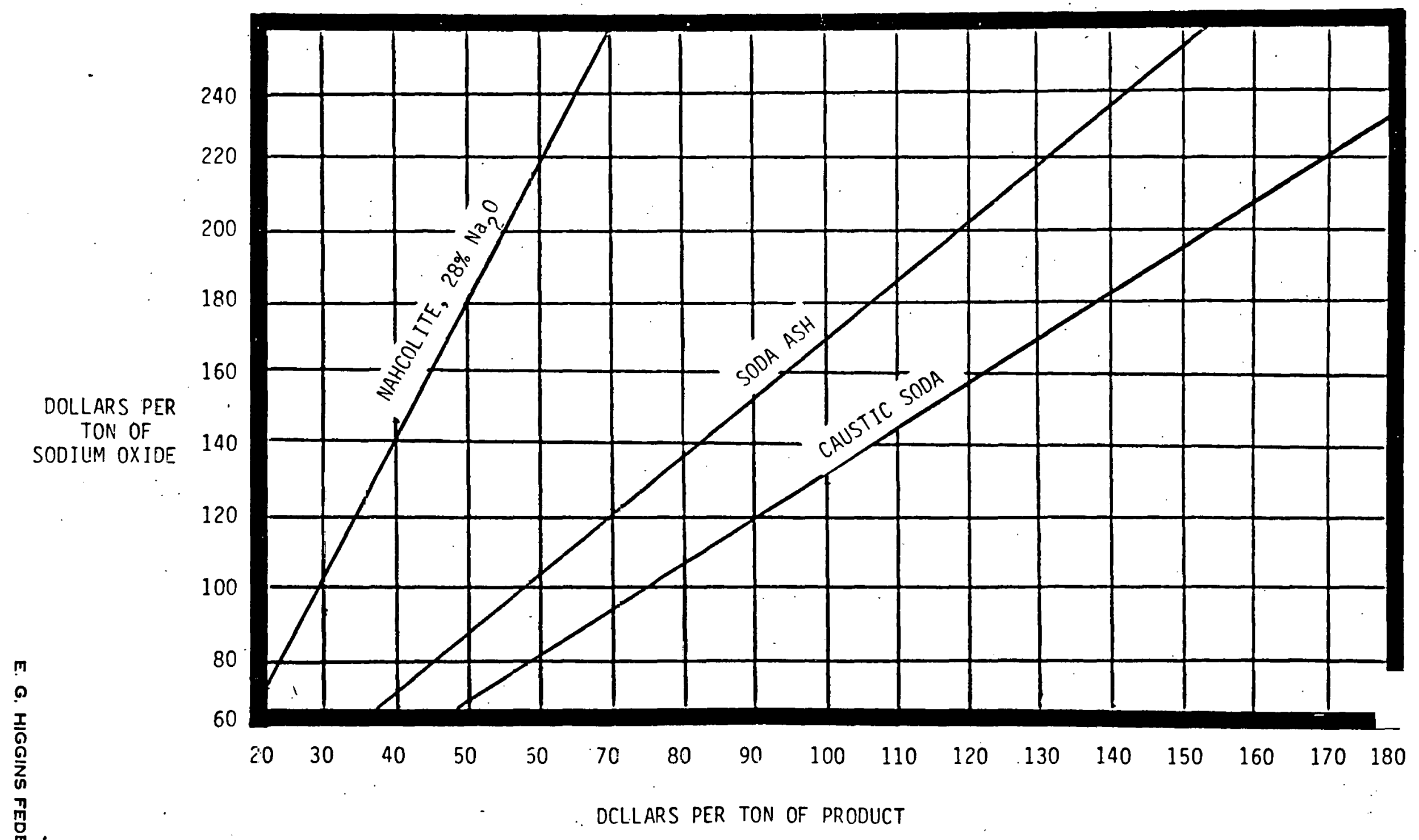


INTRODUCTION

0il shale economics have traditionally been based upon the shale oil bearing all costs of mining, feed preparation, retorting and disposal of residual spent shale. Retortable shale feedstock costs are established by the capital investment and labor costs of deep underground mining. Retorting and kerogen recovery expenses are primarily a function of the ore body kerogen content.

Shale oil values are established by the alternative costs to refiners of conventional materials, and take into account the additional processing required to make shale oil derivatives competitive in quality with petroleum based products. The substantial differences in characteristics between shale oil and petroleum result in shale oil having to bear all of the capital and operating expense necessary to make shale oil acceptable as a refinery feed. These differences can be seen more clearly in the following table:

TABLE I. I

Typical Comparative Ultimate Analys is of Raw Shale 0 il and Selected Regional Petroleum Crude Types Weight Percent

\begin{tabular}{|c|c|c|c|c|c|c|}
\hline Type & Carbon & Hydrogen & Nitrogen & oxygen & Sulfur & Total \\
\hline $\begin{array}{l}\text { Greerl Rqver } \\
\text { Shale 0il }\end{array}$ & 80.52 & 10.30 & 2.39 & 5.75 & 1.04 & 100 \\
\hline $\begin{array}{l}\text { Coalinga, } \\
\text { California }\end{array}$ & 86.40 & 11.70 & 1.14 & 0.06 & 0.60 & 100 \\
\hline $\begin{array}{l}\text { Venezuela } \\
\text { Tiajuana Med- } \\
\text { ium }\end{array}$ & 83.00 & 11.00 & 0.12 & - & 1.63 & 100 \\
\hline
\end{tabular}

Source: Nelson W. L. Petroleum Reginery Engineering; Kinetics of Decomposition of Colorado Shale, Vol. II, Campbell, 0 il \& Gas Journal

The principal difference is in the significantly higher oxygen and nitrogen content of kerogen, which must be removed by hydrogenation. Each pound of oxygen will require 0.13 pounds, or 25 SCF of hydrogen, while removal of nitrogen will consume 0.21 pounds of hydrogen per pound of nitrogen, equal to 40 SCF. The sulfur content is neither remarkably better nor worse than typical U. S. crudes being refined today, so that shale 0 il is not penalized in that regard. 
The kerogen, or shale oil content of the crude shale, however, is a relatively small proportion of the total weight of the oil shale, being between $11-12 \%{ }^{1}$ ) The remainder is composed of several minerals.

TABLE 1.2

Major Mineral Components of Selected Raw 0il Shale Weight

Mineral

Silica and Silicates

Dolomite

Calcite

Nahcolite

Dawsonite

Kerogen

Total

${ }^{*}$ From Anvil Point, Colorado mine

Formula

$\mathrm{CaCO}_{3}$

$\mathrm{NaHCO}_{3}$

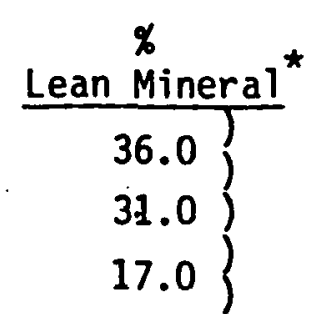

$\%$

Rich Mineral

$\mathrm{SiO}_{2}, \mathrm{SiO}_{3}$

$\mathrm{CaMg}\left(\mathrm{CO}_{3}\right)_{2}$

0.4

20.0

$\mathrm{NaAT}(\mathrm{OH})_{2} \mathrm{CO}_{3}$

12.0

56.0

3.5

12.0

$\frac{12.1}{100.0} \quad \frac{12.0}{100.0}$

Source: 0il Shale Retorting: Kinetics of Decomposition of Carbonate Minerals, J. H. Campbe11, p. 242

As can be inferred, the cost of mining a large volume of minerals, which must be disposed of after retorting, imposes a substantial economic penalty upon the retorted shale oil if there is no recovery of mineral values.

Two of the contained minerals, nahcolite and dawsonite, have significant potential value as a source of sodium carbonate (soda.ash) and aluminum oxide (alumina). The limiting case for their marketability is established by a complex interrelationship between ultimate market growth for the end uses, world trade, logistics, and competitive industry economics.

Although recovery of the sodium and aluminum values from shale oil bearing nahcolite and dawsonite is possible using present retorting systems, it is necessary to alter operating practices to do so. The reason is that retorting temperatures higher than the melting point $\left(600^{\circ} \mathrm{C}\right)$ of the combined minerals result in formation of glasses rather than recoverable crude chemicals. ${ }^{2)}$ Commercial use of the spent dawsonite and nahcolite shale as a raw material for alumina and soda ash recovery thus requires that the retorting temperatures be carefully controlled. 
At present, the only process which has been specifically designed for this purpose is the Superior 0il Company Circular Grate System, although the Bureau of Mines had postulated a similar above ground process sequence to recover mineral values from processing of oil shale. ${ }^{3)}$

The basic restraint to general application of minerals recovery to oil shale processing technology has been the concern that the resulting involuntary production of soda ash and alumina would overwhelm existing markets, with an attendant negative effect on process economics.

Single product processes, as represented by conventional oil shale retorting, have economics which are very much simpler in that the investment, operating rates and income streams are determined by only one marketable commodity. The principal disadvantage is that the plant economics are completely dependent upon the manufacturing costs for that product, and the income stream resulting.

The purpose for examining recovery of soda ash and a.lumina from spent oil shale is to determine if the marginal costs of production will be competitive with existing sources, and enhance the economics of shale oil. A commercial facility for recovery of soda ash and alumina from retorted shale requires the following assumptions:

* The product quality will be competitive and compatible with the prospective end use processes.

* The products can be delivered to markets at competive prices.

* There will not be institutional barriers to entry.

* There will be markets to absorb the production.

Alumina and soda ash markets differ substantially. Alumina has essentially only one end use: as a raw material for primary aluminum manufacture by electrolytic reduction.

Soda ash, while heavily dependent upon glass as a major market, has a wide range of other applications and can be directly substituted for caustic soda (sodium hydroxide) in many end uses, or indirectly by simple causticization with calcium hydroxide. The only question is one of economics. The output of soda ash and alumina from a multiple product oil shale scheme will be a dependent variable of the demand for shale oil rather than implicit demand for the co-products. 0il shale mineral recovery economics thus will 
closely resemble those of petroleum refineries or ethylene plants cracking heavy feedstocks, except that the markets will be much more limited in scope and location.

Oil shale based soda ash is faced with an analogous competitive product, caustic soda, whose supply is an independent variable of the demand for chlorine. Chlorine markets are quite dissimilar from those of caustic soda and are growing at different rates, so that sizeable imbalances in the demand and supply of caustic could occur in the future.

Large shortfalls in caustic supply could result in a rising demand for soda ash equivalent as a substitute sodium oxide source. Conversely, any significant excess of involuntary caustic supplies could cause displacement of soda ash from end uses capable of making the shift if the product prices indicated it to be profitable.

Finally, logistics play a critical role in oil shale mineral economics because the raw material source is land locked and far from major markets. For practical purposes, product transportation costs to market could play a more influential role in oil shale mineral recovery economic viability than the processes themselves.

The long term outlook for oil shale based mineral products, then, is dependent upon the unique position of a cormercially unaffiliated production system for two very basic chemical commodities whose costs are not necessarily similar to traditional methods and market prices.

Methods and Market Prices

The study does not address the mechanics of market entry, since the range of possibilities is quite wide. Among them are:

* purchase of co-product ash by domestic or foreign marketer/producers;

* direct purchase by end users;

* marketing by shale oil plant operators.

Rigorous definition of those markets, competitive supplies and their economics is an essential ingredient in a realistic evaluation of the oil shale co-product outlook. The following sections of this report examine the markets, economics and potential for entry by oil shale based products. 
SUMMARY AND CONCLUSIONS

\section{A. Summary}

0il shale mineral recovery economics are predicated upon the availability of markets for the two principal products:

$$
\begin{aligned}
& \text { * alumina } \\
& \text { * soda ash. }
\end{aligned}
$$

In order for these products to have market access, they must be competitive in quality and price with existing raw material sources. Alumina and soda ash are mature chemicals with end use markets growing at about real GNP, and sensitive to general economic conditions. Alumina

$90 \%$ of U. S. alumina consumption is for the production of pri= mary aluminum. Approximately $95 \%$ of U. S. alumina is imported directly as cell grade alumina, or indirectly as bauxite. The primary constraint on future demand is availability and price of electric power for smelters. Alumina is not considered a separate product, since virtually all U. S. production is produced as well as used by integrated aluminum producers.

Recovery of secondary aluminum replaced 1.95 tons of alumina for every ton of secondary aluminum recovered. Alumina manufacturing costs appear to be in the range of $\$ 180-\$ 210$ per short ton at this time, but are rising at the rate of about $8 \%$ faster than primary aluminum selling prices because of the effect of a $7.5 \%$ levy on bauxite and alumina by the International Bauxite Association (IBA).

The market for alumina in the United States alone is sufficient to consume the production from $250,000 \mathrm{BBL} /$ day of shale oil. Using dawsonite feed, it would account for about $30 \%$ of current $U$. S. demand for alumina.

Almost all U. S. alumina capacity is at least 20 years old, and some is nearly 60 . It is very likely that oil shale alumina could easily displace this high cost supply.

$30 \%$ of the U. S. primary aluminum smelter capacity is located in the Northwest United States on the Bonneville Power Administration System. The remainder is on the Texas Gulf Coast and along the TVA System. 
Approximately 110-230 pounds of caustic equivalent are required per ton of alumina produced from bauxite via the Bayer Process. The variation is a function of monohydrate to trihydrate ratio in the bauxite.

Australia has become a major alumina producer, and was the source of over 2.0 million tons imported into the U.S. Approximately $34 \%$ of U.S. a) umina requirements are imported, and rising at a compounded rate of $10 \%$ per year.

Alumina and bauxite imports accounted for $\$ 900$ million dollars in 1979, a threefold increase since 1970.

The primary markets for aluminum metal, the basic end use of alumina, are:

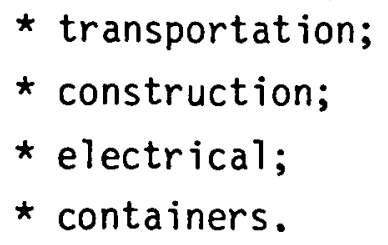

Container markets are the fastest growing and are used in two major categories:

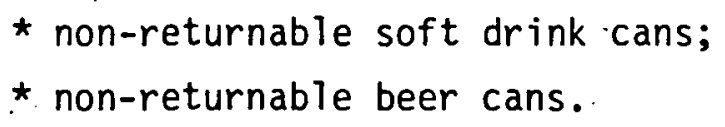

Approximately $25 \%$ of all containers are now recycled for secondary recovery, thereby saving power costs for redurtion.

Entry of an alumina source not a part of the basic aluminum industry may be very simple, or very difficult, depending upon the industry posture and economics at the time.

As long as oil shale production were competitive economically and qualitatively, it is believed that it would be assimilated without undue difficulty because of the age of some of the older capacity.

Energy costs are not as critical to alumina economics as iabor, freight and bauxite. Approximately 2.6 tons of bauxite are required per ton of alumina, so that logistics are a major consideration.

Quality of bauxite, especially silica content, is a critical process parameter, since each pound of silica will tie up a pound of 
aluminum and soda in the form of sodium alumina silicate complexes. These sodium and aluminum values are lost with the "red mud" reject to the tailings pond.

There is serious consideration being given to reprocessing red mud ponds for these values by using soda ash in a lime sinter process. If this takes place, it could require significant quantities of soda ash. Soda Ash

Soda ash is one of two basic sodium oxide sources, the other being sodium hydroxide (caustic soda). Soda ash is the carbonate form of sodium oxide, while caustic soda is the hydroxide.

Caustic for soda can be produced from soda ash by treating the latter with calcium hydroxide (slaked lime). Soda ash can be produced from caustic soda by carbonating the latter with carbon dioxide $\left(\mathrm{CO}_{2}\right)$.

Soda ash is a dry, granular product of about $60 \mathrm{lb} / \mathrm{cf}$ density, whereas the most common commercial form of caustic is as a $50 \%$ solution because higher concentrations"freeze" or must be kept steamed to prevent solidification.

Caustic soda is produced as an involuntary co-product of chlorine

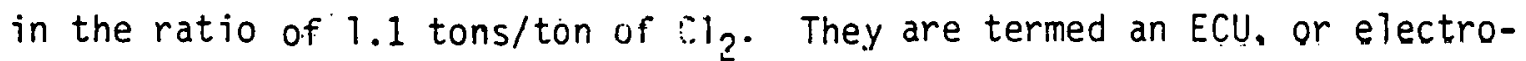
chemical unit. Chlorine production is tied to demand because of the cost and difficulty of storing it, so that chlorine output is the independent variable.

Caustic soda and soda ash share some markets, but caustic cannot replace soda ash in its major market, glass. Soda ash can replace caustic in several of its end uses, especially the Bayer Process for alumina manufacture, and kraft pulp production.

Many major chemical product processes are based upon use of a dry source of sodium oxide. Examples are Sodium Bicarbonate, Sodium Phosphates, Sodium Silicates and Sodium Chromates.

Caustic soda is utilized in most of the alumina plants in the world because of its ready availability and high reactivity. It is estimated between $7-9 \%$ of world caustic production goes into alumina manufacture. 
Rayon fiber is another substantial outlet for caustic, requiring one pound for every pound of rayon. U. S. production of rayon has declined substantially as synthetics (polyester, nylon and acrylics) pre-empted a major share of the fiber market, but appears to have reached bottom for the present. Foreign production is stable or growing very slowly, primarily in China.

Pulp and paper uses of chlorine and caustic soda for pulp bleaching are likely to decline in the $U$. S. as environmental regulations go into effect on discharge of chlorinated hydrocarbons.

Almost $50 \%$ of all chlorine utilized in chlorinated hydrocarbons was for production of VCM (vinyl chloride monomer), which is converted to PVC. The major end use of PVC is for construction pipe, with housing siding, automotive interiors, films and containers the next largest application.

Export markets for chlorinated hydrocarbons have accounted for about $7 \%$ of U. S. organic chemical production, and $3-5 \%$ of chlorine demand. The primary market was Europe which has also been the object of Eastern European exports to earn hard currency, or in the form of counter-. part trade in payment of facilities put up with Western credit.

World trade in chlorinated hydrocarbons, especially VCM, PVC or their precursors, is a substantial factor in caustic/chlorine balances. Caustic demand tends to be relatively stable, whereas chlorine demand can be highly volatile because of its dependence upon a single product, PVC.

Other chlorine uses such as chlorinated insecticides, anti-knock fluid (tetra-ethyl or methyl lead), and solvents are declining due to environmental pressures, while some synthesis routes to major derivatives such as propylene oxide, are utilizing other raw materials. Cumulatively in the $U$. S., the effect is to reduce chlorine demand growth rates.

If caustic demand were to be greater than the supply, soda ash could substitute. For each ton of caustic replaced, 1.30 tons of soda ash would be required. World production of caustic soda was approximately 29 million short tons in 1977; replacement of only $1 \%$ of this by soda ash would require around 380,000 short tons of soda ash. Any significant 
drop in caustic supplies with respect to demand as a consequence of disruptions in chlorinated derivatives markets would provide substantial potential for soda ash.

Eastern Europe exports large quantities of soda ash to Western Europe, albeit at greatly discounted prices. Should Eastern European production be blocked or unavailable because of production disruptions, it is possible that much of that market could become available to U. S. production.

Solvay process soda ash is the most costly world source and accounts for approximately $60 \%$ of world capacity. Trona and $0 i 1$ shale would be the lowest cost sources and should be able to compete in Western European and Asian markets unless there were barriers to market entry.

U. S. soda ash end uses are primarily for glass (50\%), inorganic chemicals (25\%), water treatment and other miscellaneous uses. New potential uses include lime sinter recovery of alumina, sodium thiosulfite production for thermomechanical pulp bleaching and recovery of heavy metals from effluents.

Planned and existing soda ash production capacity from trona is likely to be adequate for the foreseeable future, even if Syracuse were closed. (The last U.S. Solvay process plant.) 0 il shale based ash markets would logically be expected to be for caustic soda replacement and foreign markets where Solvay process capacity was too costly.

0il shale based soda ash; therefore, must be considered in terms of world markets and not just U. S. Availability of Canadian and Mexican ash consumption is open to question, but if it were, it would be about 800,000 tons per year.

Tariffs and trade impediments will be very important to marketing of U. S. trona and oil shale soda ash production. Offered free access to markets, it is believed U. S. production could enjoy at least a five million ton per year overseas market.

This is based upon the following assumptions:

* Japan could accommodate $1,000,000$ tons/year to replace Solvay ash;

* Australia could assimilate 300,000 tons/year for alumina production; 
* 800,000 tons of Eastern Europe's exports could be displaced from Western Europe's markets;

* 3,000,000 tons of Western European solvay process capacity would be closed.

Logistic costs will play a strong role in both foreign and domestic oil shale mineral economics. Transportation costs will be particularly critical to soda ash and nahcolite because of their remote location with respect to markets and dependence upon overland freight rates via rail.

Current production from Green River, Wyoming moves via a single carrier for much of the distance, and the production in one of the cases at least is on carrier owned property. Since all of the U. S. trona output is dependent upon a single carrier, the rates are likely to be more favorable than would be the case if only a portion were moved.

Overland movement of alumina reportedly is by unit train from the Gulf Coast plants to Northwest smelters. Since no rail facilities currently exist from Colorado oil shale facilities to markets, it is not possible to project reasonable transportation costs to smelters from Colorado. It can only be assumed that the freight rate will be lower for equivalent.tonnages and conditions of shipment if the distance is shorter. Whether this would actually be the case can only be a matter of conjecture at. this pnint. 


\section{MAJOR MARKETS FOR OIL SHALE MINERALS}

\section{A. Assumptions}

There are many factors which affect the market potential for oil shale based minerals. Among these are:

* world supply and demand balances for competitive products;

* inter-product displacement and competition;

* institutional barriers to market entry;

* existing and potential market ability to absorb output;

* technological innovations;

* changes in consumer preferences;

* demographic and econometric trends.

There are three primary products examined in this study for their impact upon shale oil recovery economics:

$$
\begin{aligned}
& \text { * Alumina }\left(\mathrm{Al}_{2} \mathrm{O}_{3}\right) ; \\
& \text { * Soda Ash }\left(\mathrm{Na}_{2} \mathrm{CO}_{3}\right) \text {; } \\
& \text { * Nahcol ite }\left(\mathrm{NaHCO}_{3}\right. \text {, crude). }
\end{aligned}
$$

Other associated retort process products such as off gas are examined in the study since utilization in an integrated facility producing both shale oil and minerals could be economically significant to the plant.

The assumptions used in an ecunomic analysis are the primary determinants of the conclusions likely to be reached, since it is the assumptions which govern the interpretation of the data selected.

A process industry market study is especially dependent upon the assumptions employed because of the wide range of variables which can be considered, unlike more closely defined engineering evaluations which are implicitly bound by process and operating conditions.

Market study constraints, however, are inherently subjective, and a function of the analyst's definition of what constitutes the market.

For purposes of this analysis, it is assumed that products employed in end use markets are proxies for functions, that is, buyers purchase functions in the form of products and choose the one which performs the entire function best. As an example, consumer containers may be made of any of the following materials, each with a different unit cost: aluminum, paper, steel, glass, polyethylene, polyvinyl, chloride, and acrylonitrile 
or polyethylene terephthalate resin, depending upon the product for which the container is used.

In each case, the buyer is assessing a broad range of products, but only one function, packaging. The choice will be based upon not only unit cost, but other considerations such as legal constraints upon use in specific applications, effect upon gross sales inc marketing costs, and even ability to make rather than buy.

Ultimately the product choice is driven by economics, but not just the narrowly defined economics of unit cost. Rather, the decision is on a much broader base, often determined by demographic and societal trends, which reflect national characteristics. While there has been a trend toward more homogenous world markets, there still remain inherent national differences which affect demand for basic chemical products.

Where possible, the effect of these natural variations has been taken into account for major markets.

The second assumption is that the comodity selling prices tend to reflect process economics. This is primarily because costs downstream of of manufacturing, such as marketing, are usually small in comparison to those of raw materials, capital investment, and direct operating expenses. Basic manufacturing costs heavily influence the competitive posture of processes and often the derivative products. Transportation costs are site specific and normally borne by the buyer rather than seller, and so do not impact $F O B$ works prices, except in the form of freight equalization.

Comparative process economics are assumed to determine the competitive posture of products, subject to acceptance in the specific market place of the equivalent materials in end uses capable of using alternates. If selling prices track manufacturing costs, processes with inherently lower costs should have a significant market advantage, so that process economics are of critical marketing importance.

A derivative assumption is that markets for alumina and basic chemicals are international and that there will be no prohibitive tariffs or other barriers that would preclude entry of products having more favorable process economirs into markets whose dominant process source is inherently uneconomic. This is probably the most important of the study assumptions since it can have basic implications for oil shale based soda ash. 
Environmental influences upon supply or demand are assumed to be primarily political in nature, and therefore unforecastable in their trends. In general, laws and regulations in place at the time of the study are assumed to be those which will be in the future, and enforced to the same degree as at present.

Energy prices, an important process industry cost component, are assumed to rise, in constant dollars, at the rate of $2 \%$ per year unless there are data which specifically contradict the use of this rate.

It is assumed that involuntary co-product supplies, such as caustic soda, will more preferentially to markets, and that discretionary supplies will supply the remainder. It is possible that once marketing channels are established that co-product soda ash could occupy a comparable position to that of caustic soda.

Where producers of a basic commodity are also consumers, it is assumed that these captive markets will be supplied preferentially by captive sources for at least $50 \%$ of needs.

It is assumed that unaffiliated production of products is by definition a wholly merchant supply which must be marketed in the non-captive, i.e. merchant, market.

It is also assumed that buyers will not shift between equivalent materials which are significantly different in form or characteristics, even with a substantial difference in equivalent cost, unless that differential is perceived as likely to persist for a period long enough to amortize any investment or costs associated with the switch. These costs may include storage, handling, yield changes and so forth.

Finally, it is assumed that the products produced from oil shale will be substitutable in quality for current market materials. This is particularly critical in the case of cell grade alumina which has no significant use other than for primary alumina production.

The assumptions may be summarized as follows:

* The outlook for primary markets for oil shale based products will be largely determined by the functional cost effectiveness of the secondary products in end use applications.

* Commodity selling prices track the manufacturing economics of the dominant process.

* Alumina and soda ash are international trade products. 
* Environmental constraints in the future will not differ significantly from those in place in 1980.

* Energy costs will rise at $2 \%$ per year in 1980 constant dollars.

* Involuntary (co-products) supplies of products will move preferentially to market.

* Captive markets will be preferentially served by captive producing facilities.

* Interproduct substitution will only take place where price differentials, on an equivalent basis, are seen by buyers to be fundamental, rather than transient.

* 0 il shale based products will be substitutable in quality, performance and economics with currently available commercial materials.

\section{B. WORLD TRADE PATTERNS}

\section{Demographic and Econometric Factors in Markets}

Aluminum and soda ash are mature products with well defined markets whose technological capabilities have largely been exploited in their existing end uses. While the possibility of new applications is always present, it is unlikely that any of them would become statistically significant in terms of the present production base, in less than five to seven years, if only because of the large existing demand.

Market growth for mature commodities tends to be strongly related to demographics and economic conditions, with per capita income one of the most important determinants. Structural declines in demand for chemical commodities tend to be a consequence of major technological changes in end use markets and are usualiy not reversible.

Industrial commodities have their primary markets in nations with a substantial manufacturing infrastructure, since the basic products are typically several steps removed from their ultimate use in the form of consumer or commercial products. Commodity chemical markets, therefore, are characterized by high population densities and relatively high per capita income.

The principal world industrial commodity markets can be geographically grouped as follows:

* North America;

* Western Europe;

* Japan, Taivan and Korca;

* Indian Subcontinent. 
While the communist bloc nations, including China and Eastern Europe, are large commodity chemical end users, they are as a rule either self sufficient or exporters to Western Europe. Chemical exports are used to earn hard currencies to purchase critical goods or technologies not available internally. The markets likely to be available to U. S. oil shale minerals, therefore, are in the market, rather than controlled economies.

The regional world population rankings for major groupings through 1976 are as follows:

TABLE 3.1

Ranked Major World Population Groupings Militions

\begin{tabular}{|c|c|c|c|c|}
\hline Group & $\underline{1950}$ & 1970 & 1976 & $\frac{\% \text { Annual Change }}{1950-1976}$ \\
\hline Asial) & 1368 & 2027 & 2304 & 2.0 \\
\hline Europe 2 ) & 392 & 459 & 476 & 0.7 \\
\hline N. and S. America ${ }^{3)}$ & 3.30 & 509 & 572 & 2.2 \\
\hline Africa & 219 & 352 & 412 & 2.7 \\
\hline USSR & 180 & 243 & 258 & 1.5 \\
\hline Oceania & 13 & 19 & 22 & 2.0 \\
\hline Total & 2502 & 3609 & 4044 & 1.9 \\
\hline
\end{tabular}

Source: Statistical Yearbook, United Nations, 1977

1) Includes China, Japan, Indian Subcontinent and Middle East

2) Includes Western and Eastern Europe

3) Includes Canada, Mexico, U. S., Central and South America.

These groupings, however, do not reflect the commercial potential for basic materials such as soda ash and alumina. The table on the following page illustrates the relative population rankings of the various major world markets, but without consideration for the economic size, a function of income, are shown.

The economic size is a function primarily of national income.

A low national income implies a very smali consumer market for products using basic chemical products, since there is little discretionary income available for purchase of non-critical service items. Per capita income relationships to national markets are discussed later in this section. 
TABLE 3.2

Principal Industrial and Developing Economy Markets for Industrial Commodities, Ranked by Population

Millions

\begin{tabular}{|c|c|c|c|c|}
\hline egion or Major Nations & 1970 & $\%$ & 1976 & $\%$ \\
\hline $\begin{array}{l}\text { India, Pakistap) } \\
\text { Western Europq) } \\
\text { North America }) \\
\text { South America } 4 \text { ) } \\
\text { Southeast. Asia } 4 \text { ) } \\
\text { Middle East }\end{array}$ & $\begin{array}{r}720 \\
356 \\
280 \\
187 \\
123 \\
77 \\
\end{array}$ & $\begin{array}{r}21 \\
10 \\
8 \\
5 \\
3 \\
2 \\
\end{array}$ & $\begin{array}{r}823 \\
363 \\
304 \\
218 \\
134 \\
91 \\
\end{array}$ & $\begin{array}{r}20 \\
9 \\
7 \\
5 \\
2 \\
2 \\
\end{array}$ \\
\hline Sub-Total & 1743 & 48 & 1938 & 47 \\
\hline World Total ${ }^{5)}$ & 3610 & 100 & 4044 & 100 \\
\hline
\end{tabular}

1) Austria, Belgium, Denmark, Finland, France, West Germany, Greece, Ireland, Iceland, Italy, Luxemborg, Netherlands, Norway, Portugal, Sweden, Switzerland, United Kingdom

2) U. S., Canada, Mexico

3) Includes Central America

4) Includes Japan, Oceania (Australia)

5) Includes managed economies and Africa

Source: United Nations Statistical Yearbook 1977

The economic picture, however, is quite different. The total national income for the market economies from 1960-1975, the last year for which data were available, were as follows: (Eastern Bloc Nations are not reported in these tabulations.)

TABLE 3.3

World Industrial Market Economies Ranked by National Income Billions of Dollars

\begin{tabular}{|c|c|c|c|c|c|}
\hline Region or Major Nation & $\underline{1960}$ & $\%$ & $\underline{1970}$ & $\%$ & $\underline{1975}$ \\
\hline $\begin{array}{l}\text { North America } \\
\text { Western Europe } \\
\text { Japan, So. Korea, Australia } \\
\text { India, Pakistan }\end{array}$ & $\begin{array}{r}497 \\
325 \\
58 \\
37 \\
\end{array}$ & $\begin{array}{r}49 \\
32 \\
6 \\
4\end{array}$ & $\begin{array}{r}981 \\
695 \\
212 \\
61 \\
\end{array}$ & $\begin{array}{l}44 \\
31 \\
10 \\
3\end{array}$ & $\begin{array}{r}1560 \\
1527 \\
552 \\
\text { est. } 85 \\
\end{array}$ \\
\hline Sub-Total* & 917 & 91 & 1949 & 88 & 3724 \\
\hline Iorld Total Market & S & 100 & 2226 & 100 & 4441 \\
\hline
\end{tabular}

* Market economies on $7 y$, excludes Communist Bloc countries

Source: United Nations Statistical Yearbook 1977 
As Tables 3.2 and 3.3 show, Western Europe and North America account for $18 \%$ of world population but $69 \%$ of the national income of market economies (as opposed to managed or conmunist bloc), basis market value.

Japan was the largest gainer in percentage terms, rising from a $6 \%$ share of market economy national income to $12 \%$, and from having a national income of only 18\% of Western Europe's in 1960 to $36 \%$ in 1975. Since that time, Japan has significantly improved its income by vigorous export trade.

The most significant development is that Western Europe has exceeded U. S. income growth rates, rising from a national income base of 65\% of North America's in 1960 to $98 \%$ by 1975 . Much of this growth came from chemicals and automobiles, the latter using sodium oxide as glass and aluminum.

The most critical aspect of national incomes is how they were developed. Foreign trade has been especially influential in the prosperity of West Germany and Japan, both of whom are almost totally dependent upon imported energy sources. They both have managed to off set this unfavorable circumstance by agressive marketing of high value added export items such as cars and trucks. This has resulted in a favorable balance of trade with the substantial benefits which this confers on the economies of those nations.

In general Western Europe and Japan have tended to follow a policy of purchasing lower cost raw materials and selling finished products. The exception to this rule is when substantial unemployment will result from import of cheaper competitive products. In that case, economics are subordinate to the social considerations. The reason is that non- U.S.economies are relatively inflexible in their ability to deploy labor made redundant by closed plants. Manufacturers with marginally economic plants thus consider the alternative costs of closing the facility, which may be greater than those of continued operation. If too great a discrepancy exists between indigenous and imported material, price is likely to force the issue. Soda ash is likely to be a prime example of this conflict in interests between producers and consumers.

Estimates of potential export trade advantages conferred by process economic differentials must be tempered, therefore, by a realistic 
assessment of the willingness of industrialized nations to permit imports to close even uneconomic plants, unless balanced by other considerations.

World trade balances by region from 1963 to 1976 are summarized in the table belaw:

TABLE 3.4

World Trade for Selected Regions, 1963-1976

Billions of Dollars

Region
Developed Market Eco-

nomies

Developing Nations 3 )

OPEC

$\underline{\text { Item }}$

$\underset{\text { Exports }}{\text { Imports }}$ 2)

Imports

Exports

Imports

Exports

Planned Economies

World Total
Imports

Exports

Imports

Exports $\underline{1963}: \underline{1976}$

$111 \quad 794$

$104 \quad 643$

146

118
67

135

105

93

1022

989

Annual \% Change

1) CIF (cargo, insurance and freight, delivered)

2) $F O B$ (cost at point of shipment)

3) LesS OPEC

Source: United Nations Statistical Yearbook, 1977

Within those groupings, however, a relatively few nations accounted for disproportionate amounts of imports and exports. The United States had the largest portion of world trade, but in terms of exports was closely follaned by west Cermany. As mentioned earlier, the dollar value of export trade is heavily determined by its composition.

Developing nations typically export lay value rav materials such as crude oil, mineral ores and basic agricultural commodities dependent upon cheap labor such as cocoa, jute and natural rubber. İndustrial nations export high value added consumer industrial products, e.g. automobiles, electronics and chemicals.

Historic trade balances for major regions of the world can be seen in the tale on the following paye. 
TABLE 3.5

Import-Export Balance for Selected Nations $1963-1976$

Billions of Dollars

\begin{tabular}{|c|c|c|c|c|c|}
\hline Nation & $\begin{array}{c}\text { Economy } \\
\text { Type } \\
\end{array}$ & Item & $\underline{1963}$ & 1976 & $\begin{array}{l}\% \text { Annual } \\
\text { Change }\end{array}$ \\
\hline United States & $\begin{array}{l}\text { Developed } \\
\text { Market }\end{array}$ & $\begin{array}{l}\text { Imports } \\
\text { Exports }\end{array}$ & $\begin{array}{l}17 \\
23\end{array}$ & $\begin{array}{l}129 \\
113\end{array}$ & $\begin{array}{l}16.9 \\
13.1\end{array}$ \\
\hline West Germany & $\begin{array}{l}\text { Developed } \\
\text { Narket }\end{array}$ & $\begin{array}{l}\text { Imports } \\
\text { Exports }\end{array}$ & $\begin{array}{r}13 \\
8\end{array}$ & $\begin{array}{l}88 \\
56\end{array}$ & $\begin{array}{l}15.8 \\
16.2\end{array}$ \\
\hline France & $\begin{array}{l}\text { Developed } \\
\text { Market }\end{array}$ & $\begin{array}{l}\text { Imports } \\
\text { Exports }\end{array}$ & $\begin{array}{l}9 \\
2\end{array}$ & $\begin{array}{c}64 \\
9\end{array}$ & $\begin{array}{l}16.3 \\
12.3\end{array}$ \\
\hline Japan & $\begin{array}{l}\text { Developed } \\
\text { Market }\end{array}$ & $\begin{array}{l}\text { Imports } \\
\text { Exports }\end{array}$ & $\begin{array}{l}7 \\
5 \\
\end{array}$ & $\begin{array}{l}65 \\
67 \\
\end{array}$ & $\begin{array}{r}78.7 \\
22.2 \\
\end{array}$ \\
\hline Sub-Total & $\begin{array}{l}\text { Developed } \\
\text { Narket }\end{array}$ & $\begin{array}{l}\text { Imports } \\
\text { Exports }\end{array}$ & $\begin{array}{l}46 \\
38\end{array}$ & $\begin{array}{l}346 \\
245\end{array}$ & $\begin{array}{l}16.8 \\
15.2\end{array}$ \\
\hline World Total & $\begin{array}{l}\text { Market } \\
\text { Economies }\end{array}$ & $\begin{array}{l}\text { Imports } \\
\text { Exports }\end{array}$ & $\begin{array}{l}16.3 \\
155\end{array}$ & $\begin{array}{c}1022 \\
989\end{array}$ & $\begin{array}{l}15.2 \\
15.3\end{array}$ \\
\hline
\end{tabular}

Source: United Nations Statistical Yearbook, 1977

As can be seen, of the developed nations selected, Japan alone $v$ as able to achieve a favorable trade balance in spite of the highest percentage increase in imports. This was largely accomplished by a vigorous policy of exporting high value added products such as automililes and electronics, while importing low cost raw materials. Although the petroleum import expenditures were large, the unit cost is relatively low compared to the products exported. At current OPEC prices, crude oil is about $\$ 260 /$ metric tonne, while a typical autombile at $\$ 4,000$ wholesale and weighing 1800 bs. is equal to $\$ 4,900$ per tonne. The key, of course, is the number of units of oil required per unit exported.

The principal trade barriers which nations erect are against items with a high value added component, particularly if the item has a significant lab or content. 4) The United States is a major dissenter to this practice and with some exceptions has the fevest restric tions upon imports of any industrialized nation. Whether this will continue to be so is a matter of conjecture due to the current status of the domestic automobile industry. 
In terms of trade blocs, world trade patterns were reported to be as follaws for the years 1964 and 1976:

TABLE 3.6

\section{World Trade Patterns for Selected Trading Blocs \\ Billions of Dollars}

\begin{tabular}{|c|c|c|c|c|c|}
\hline Trade $B 10 C$ & $\begin{array}{c}\text { Economy } \\
\text { Type } \\
\end{array}$ & Item & 1963 & 1976 & $\begin{array}{l}\% \text { Annual } \\
\text { Change } \\
\end{array}$ \\
\hline North Americal) & Developed & $\begin{array}{l}\text { Imports } \\
\text { Exports }\end{array}$ & $\begin{array}{l}25 \\
23\end{array}$ & $\begin{array}{l}170 \\
113\end{array}$ & $\begin{array}{l}15.9 \\
13.1\end{array}$ \\
\hline $\begin{array}{l}\text { South America/ } \\
\text { Caribb ean }\end{array}$ & Developing & $\begin{array}{l}\text { Imports } \\
\text { Exports }\end{array}$ & $\begin{array}{l}11 \\
11\end{array}$ & $\begin{array}{l}59 \\
52\end{array}$ & $\begin{array}{l}13.8 \\
12.7\end{array}$ \\
\hline W. Europe ${ }^{2)}$ & Developed & $\begin{array}{l}\text { Imports } \\
\text { Exports }\end{array}$ & $\begin{array}{l}72 \\
63\end{array}$ & $\begin{array}{l}435 \\
394\end{array}$ & $\begin{array}{l}14.9 \\
15.1\end{array}$ \\
\hline E. Europe ${ }^{3)}$ & $\begin{array}{l}\text { Centrally } \\
\text { Planned }\end{array}$ & $\begin{array}{l}\text { Imports } \\
\text { Exports }\end{array}$ & $\begin{array}{l}19 \\
18\end{array}$ & $\begin{array}{r}104 \\
90\end{array}$ & $\begin{array}{l}13.9 \\
13.2\end{array}$ \\
\hline Africa ${ }^{4)}$ & $\begin{array}{l}\text { Developing } \\
\text { So. Africa }\end{array}$ & $\begin{array}{l}\text { Imports } \\
\text { Exports }\end{array}$ & $\begin{array}{r}26 \\
8\end{array}$ & $\begin{array}{l}47 \\
46\end{array}$ & $\begin{array}{r}4.7 \\
14.4\end{array}$ \\
\hline Middle East ${ }^{5}$ ) & Developing & $\begin{array}{l}\text { Imports } \\
\text { Exports }\end{array}$ & $\begin{array}{l}5 \\
6\end{array}$ & $\begin{array}{r}53 \\
100\end{array}$ & $\begin{array}{l}19.9 \\
24.0\end{array}$ \\
\hline Other Asia ${ }^{6)}$ & $\begin{array}{l}\text { Developed \& } \\
\text { Developing }\end{array}$ & $\begin{array}{l}\text { Imports } \\
\text { Exports }\end{array}$ & $\begin{array}{l}21 \\
22\end{array}$ & $\begin{array}{l}187 \\
239\end{array}$ & $\begin{array}{l}18.4 \\
20.3\end{array}$ \\
\hline & & Source: & $\begin{array}{l}\text { United } \\
\text { Yearb oo }\end{array}$ & $\begin{array}{l}\text { ions } \\
1977\end{array}$ & atistical \\
\hline
\end{tabular}

1) Canada, U. S.

2) EEC, EFTA plus treece, Spain

3) Albania, Bulgaria, Czechoslavakia, East Cermany, Hungary, Poland, Romania, Yugoslavia, USSR

4) Includes North Africa

5) Includes petroleum

6) Includes Indonesia, Australia, Archepeligo and Indian Subcontinent, Japan. Excludes China, North Korea

The most remarkab le change, as can be seen above, is the very large grow th which has taken place in Western Europe's import and export trade compared to the United States, and how the spread has changed in absolute amounts. Much of the European export growth can be attributed to a vigorous export policy supported by a tax structure (VAT, or Value Added Tax) which favors export over internal sales. This shift has been summarized in the table on the following page. 


\section{TABLE 3.7}

Comparison of Western Europe, Japan and North American Trade 1963-1976

Billions of Dollars - Net

Trade Bloc

North America

Western Europe

Japan $\underline{1963}$

(2)

(9.)

(1)
1976

(57)

(41)

2
\% Annual Change 1963-1976
20.7

12.4

$-8.1^{\star}$

Source: E. G. Higgins Federal

from U. N. Data

() indicates unfavorable trade balance

* negative number shows favorable change in trade balance

A major determinant of the potential demand for basic indus-. trial commodities such as alumina and soda ash is per capita national income. Per capita incomes for selected market economy nations are. shown. in the table following:

TABLE 3.8

Per Capita Incomes of Selected Narket Economy Eroupings $1960-1975$

Dollars

\begin{tabular}{|c|c|c|c|}
\hline Item & 1960 & 1975 & $\begin{array}{c}* \text { Annuai } \\
\frac{\text { Change }}{1960-1975}\end{array}$ \\
\hline 1 market economies & 520 & 1660 & 8.2 \\
\hline veloped market economies & 1350 & 4880 & 8.9 \\
\hline eveloping market economies & 130 & 430 & 8.3 \\
\hline
\end{tabular}

Source: United National Statistical Yearbook, 1977

As can be inferred by comparison of the per capita income tab les with previous population and national income table, the industrial markets required for alumina and soda ash are restricted to a relatively few industrialized economies, primarily the United States, Western Europe and Japan. There are a few minor exceptions to this generalization, but for the most part it is representative of the actual case. 
The fer capita incomes for selected trading blocs and nations are shown in the following table.

TABLE 3.9

Per Capita Incomes of Selected Market Economies and Nations Dollars

\begin{tabular}{|c|c|c|c|}
\hline Economy or Nation & 1960 & $\underline{1976}$ & \% Annual Change \\
\hline North America & 2450 & 7030 & 6.8 \\
\hline United States & 2502 & 6995 & 6.7 \\
\hline West Germany & 1222 & 6451 & 10.9 \\
\hline France & 1202 & 5860 & 10.4 \\
\hline EEC & 1070 & $4660^{\star}$ & 10.3 \\
\hline Japan & 417 & 4478 & 16.0 \\
\hline United Kingdom & 1261 & 3530 & 6.8 \\
\hline Southeast Asia & 120 & $540^{\star}$ & 10.0 \\
\hline
\end{tabular}

*1975 Data

Source: United Nations Statistical Yearbook 1977

High per capita incomes imply the existence of sizeable consumer markets for goods and services utilizing materials such as glass, and aluminum and plastics which are based upon soda ash, chlorine or caustic as raw materials. It is these markets with their substantial domestic and export raw material requ:irements wnich represent the princif 1$]$ demand for soda ash, caustic and chlorine.

Export markets for commodity chemicals, therefore, are least likely to be found in semi-developed market economies such as India, even though there are large populations, and most likely to be in highly developed industrial societies with existing production capacity.

The export market for commodity chemicals thus will tend to be a function of comparative production economics and protective tariffs for each potential importing nation. This will be especially true of soda ash and chlorinated hydrocarbons markets. It will be less true of alumina because of the structure of its market, which is essentially captive.

The significance to oil shale based mineral production is that world markets may be an important economic consideration for both soda ash 
and/or nahcolite, but less so for alumina. World trade in alumina, soda ash and caustic is discussed in the following section.

2. World Trade in Alumina and Sodium Oxide Related Chemicals

History and Development

As has been well documented, much of the industrialized nations' recent unfavorable trade balances are attributable primarily to oil imports. The U. S., however, is also a major importer of such basic raw materials as alumina and bauxite ore, both for manufacture of primary aluminum. The principal reason for this is that the aluminum industry had its base in the United States where large pools of inexpensive power were available based upon low cost natural gas in the Southwest and hydroelectric sources in the Northwest and TVA areas. More critically, a major market existed in the form of large commercial and military aircraft industries, assuring favorable operating rates. Since aluminum reduction is a capital and energy intensive commercial process, electric power for reduction of alumina is a major manufacturing cost component of primary aluminum, as are operating rates.

In addition to cheap power, the United States had large supplies of co-product caustic soda derived from contiguous chlorine plants constructed to provide feed stocks for organic chlorination processes.

These supplies of caustic provided a convenient and competitive $\mathrm{Na}_{2} \mathrm{O}$ source for the Bayer process digestion of bauxite, which produces alumina for the smelting step. Caustic soda selling prices, moreover, were usually competitive with the nominally lower cost soda ash. Thus, the convenience and higher reactivity of caustic soda, even if the equivalent cost were higher, made caustic soda the $\mathrm{Na}_{2} \mathrm{O}$ source eventually selected.

Lacking the broad and diversified caustic soda market base of the U. S., European caustic soda demand can be more heavily influenced by primary aluminum production rates, hence alumina demand. ${ }^{5)}$ The caustic supply, however, is dependent upon chlorine demand, principally for use in chlorinated hydrocarbons production.

Soda ash operating rates throughout the world are in response to demand since at present there is no involuntary supply. Indigenous ash 
production rates, however, can be affected considerably by two major influences:

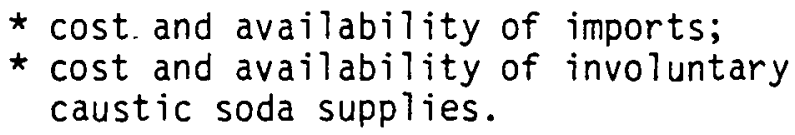

Western Europe carries on significant trade with COMECON (Eastern Bloc) countries, particularly counterpart trade. This is of great importance in Western European chemical trade balances, especially soda ash. ${ }^{6}$ )

Counterpart trade is the result of what are essentially barter arrangements to sell technology and plants on credit, with repayment to be made from a percentage of the plant production. In a sense, counterpart trade is a wholly involuntary supply to the receiving country.

For the importer, the product has only a fiat value. Naturally it is desirable that the production be sold at full market value, but this often is not an easily attained objective, either because of buyer resistance due to fears of poorer quality, uncertain delivery or other commercial objections. ${ }^{7}$ )

Counterpart trade products typically are ones which have large, well established markets such as plastics or resins, are relatively expensive insofar as commodity chemicals are concerned, have straightforward processing schemes and.are usually derivatives of ethylene or benzene if organic. Their primary importance is that they often are large chlorine consumers, hence affect caustic supplies which compete with soda ash in sodium oxide markets.

In addition to counterpart trade, the Eastern BToc nations trade heavily with the West, either because of special ties such as those of the German Federal Republic (West Germany) and Peoples Democratic Republic of Germany (East Germany), or because of price logistics. ${ }^{8}$ )

COMECON (Eastern European) bloc nations are weakest in products requiring after sale backup in the form of service or distribution networks, and have relatively few mineral resources available for export.

In actual fact, the Soviets have apparently embarked on a vigorous campaign to acquire control of a variety of strategic minerals such as chromite, manganese and cobalt ores required for high technology products. $\left.{ }^{9}\right)$ 
A major exception to this, however, has been Poland's large exports of sulfur to Western markets in order to earn hard currency.

With a COMECON b loc marketing disadvantage in machinery and other high value items, and with a poor resource base except in such materials as salt and limestone, export efforts have been directed tavard chemical products which utilize these rav materials.

Reported trade data for selected COMECON countries in 1963 and 1976 were as follows:

TABLE 3.10

Reported Trade Data for Selected Comecon Nations 1963-1976 Billions of Dollars

\begin{tabular}{|c|c|c|c|c|}
\hline Nation & Item & $\underline{1963}$ & 1976 & $\%$ Annual Change \\
\hline Bulgaria & $\begin{array}{l}\text { Import } \\
\text { Export }\end{array}$ & $\begin{array}{l}0.9 \\
0.8\end{array}$ & $\begin{array}{l}5.6 \\
5.4\end{array}$ & $\begin{array}{l}15.1 \\
15.8\end{array}$ \\
\hline Czechoslovakia & $\begin{array}{l}\text { Import } \\
\text { Export }\end{array}$ & $\begin{array}{l}2.2 \\
2.5\end{array}$ & $\begin{array}{l}9.7 \\
9.0\end{array}$ & $\begin{array}{l}12.1 \\
10.4\end{array}$ \\
\hline East Germany & $\begin{array}{l}\text { Import } \\
\text { Export }\end{array}$ & $\begin{array}{l}2.3 \\
2.7\end{array}$ & $\begin{array}{l}13 . ? \\
11.4\end{array}$ & $\begin{array}{l}14.4 \\
11.7\end{array}$ \\
\hline Hungary & $\begin{array}{l}\text { Import } \\
\text { Export }\end{array}$ & $\begin{array}{l}1.3 \\
1.2\end{array}$ & $\begin{array}{l}5.5 \\
4.9\end{array}$ & $\begin{array}{l}11.7 \\
11.4\end{array}$ \\
\hline Poland & $\begin{array}{l}\text { Import } \\
\text { Export }\end{array}$ & $\begin{array}{l}2.0 \\
1.8\end{array}$ & $\begin{array}{l}13.9 \\
11.0\end{array}$ & $\begin{array}{l}16.1 \\
14.9\end{array}$ \\
\hline Romania & $\begin{array}{l}\text { Import } \\
\text { Export }\end{array}$ & $\begin{array}{l}1.0 \\
0.9\end{array}$ & $\begin{array}{l}6.1 \\
6.1\end{array}$ & $\begin{array}{l}15.0 \\
15.8\end{array}$ \\
\hline USSR & $\begin{array}{l}\text { Import } \\
\text { Export }\end{array}$ & $\begin{array}{l}7.1 \\
7.3\end{array}$ & $\begin{array}{l}38.1 \\
37.2\end{array}$ & $\begin{array}{l}13.8 \\
13.3\end{array}$ \\
\hline $\begin{array}{l}\text { Eastern Bloc - } \\
\text { Total }\end{array}$ & $\begin{array}{l}\text { Import } \\
\text { Export }\end{array}$ & $\begin{array}{l}17.6 \\
17.2\end{array}$ & $\begin{array}{l}95.7 \\
85.2\end{array}$ & $\begin{array}{l}14.0 \\
13.1\end{array}$ \\
\hline
\end{tabular}

Trade in Ceneral Chemicals and Soda Ash

General chemicals are those which are basic commodities necessary for an industrial society's production system. Typical of these are the traditional work horse chemicals of caustic soda, chlorine, sulfuric acid and soda ash. 
The shares of world trade in chemicals by selected economies between 1970 and 1976 are surmarized with the following table:

TABLE 3.11

Share of World Chemical Trade by Selected Economies 1970-19.76

\begin{tabular}{|c|c|c|c|}
\hline Economy & Type & 1970 & 1976 \\
\hline Market & Deve loped ${ }^{1)}$ & 88.7 & 88.2 \\
\hline Market & Developing ${ }^{2)}$ & 4.0 & 4.4 \\
\hline Market & OPEC Developing & 0.3 & 0.9 \\
\hline Centrally Planned & All & 7.1 & 6.5 \\
\hline Western Europe ${ }^{3)}$ & Developed & 59.9 & 62.6 \\
\hline United States. & Developed & 17.5 & 14.5 \\
\hline Japan & Developed & 5.6 & 5.4 \\
\hline
\end{tabular}

1) Total Market, Developed

2) LesS OPEC

3) EEC plus EFTA

Source: United Nations Statistical Yearbook 1977

The United States had a 3\% drop in share of world trade in chemicals between 1970 and 1976, while developing nations and Western European nations increased their market shares. The centrally planned economies had a $0.6 \%$ drop in their share.

Chemical trade in low cost commodities bears on oil shale mineral potential, particularly soda ash. Soda ash exports have considerable variance in their importance to different nations. The established producing nations were those based upon the original Solvay process plants, some of which date back to the late 19th century, together with their antecedent LeBlanc process units. The lead nations were Belgium, France, Germany and England.

After World War II there was a drive to become self sufficient in critical chemicals, or to develop export capability by nations which had been consumers. The bulk of non-U. S. ash capacity increases in the past 25 years have been in the COMECON countries, and primarily utilized for export sales as can be seen in the following table. 
TABLE 3.12

Soda Ash Exports as a Percentage of Production for Selected Nations 1977

\begin{tabular}{llcc} 
Nation & Economic Group & $\begin{array}{c}\text { Production } \\
\text { Million Tons }\end{array}$ & $\begin{array}{c}\text { Exports as \% } \\
\text { of Production }\end{array}$ \\
\cline { 2 - 3 } United States & Developed Market & 7010 & 9.8 \\
USSR & COMECON & 4876 & 1.2 \\
United Kingdom & EEC & $1550^{\star}$ & 9.5 \\
France & EEC & 1365 & 17.6 \\
West Germany & EEC & 1351 & 7.9 \\
Japan & Developed Market & 1173 & 2.9 \\
Bulgaria & COMECON & 1194 & 75.0 \\
Romania & COMECON & 861 & 56.8 \\
* Estimate by E. G. Higgins Federal & &
\end{tabular}

The preponderance of East European total soda ash exports of 1.8 million tons in 1977 was to Western Europe and estimated to be 777,000 tons ${ }^{10)}$ or $43 \%$. The production was entirely based upon Solvay Process. Plans are for significant capacity increases in Eastern Europe, especially Poland, but are primarily for export in order to earn hard currency.

If the maturity of domestic soda ash markets suggests a limited growth potential from new uses, caustic soda replacement and export markets assume a much greater importance to oil shale based ash production. If it is assumed that the process with the lowest cost will become the primary source, then Solvay process ash should be vulnerable to displacement by oil shale and trona based ash if no artificial obstacles are raised to entry. Since trona based ash has already displaced the Solvay process in the U. S., oil shale co-product will not have an inherent cost advantage as could be the case in Europe and Japan, assuming competitive ocean freight. World Alumina Trade

Alumina is a unique product in that it has virtually no open market due to its restricted end use as primary aluminum feed. As a result, the largest producers as well as consumers are integrated primary aluminum producers. U. S. alumina trade is shown on the following page. 
TABLE 3.13

U. S. Trade in Alumina 1970-1978

Thousands of Short Tons

\begin{tabular}{|c|c|c|c|}
\hline Item & 1970 & $\underline{1978}$ & $\%$ Annual Change \\
\hline Imports & 2555 & 4371 & 7.0 \\
\hline Exports & 1024 & 967 & $(0.7)$ \\
\hline Net Imports & 1531 & 3403 & 10.5 \\
\hline
\end{tabular}

Imported alumina and its predecessor ore, bauxite, furnish the great preponderance of U.S. supplies for manufacture of primary aluminum. The principal reason for this is that domestic ores have a high silica content which is costly to remove by the lime/sinter process. This requires the use of soda ash, limestone and kiln fuel. It is less costly to purchase higher quality bauxite or alumina than it is to process domestic ore. In addition, major domestic primary aluminum producers have large investments in foreign mines, alumina plants and ships whose underuse is too costly to accept.

Finally, alumina plants are designed to use specific ores and are of ten unable to accept other sources.

-The history of U. S. alumina and bauxite sources is seen in the next table.

\section{TABLE 3.14}

U. S. Supply of Alumina and Bauxite by Source Thousands of Short Tons

\begin{tabular}{|c|c|c|c|c|}
\hline Commodity & Supply & 1970 & 1978 & \% Annual Change \\
\hline \multirow[t]{2}{*}{$\begin{array}{l}\text { Bauxite for } \\
\text { Alumina }\end{array}$} & $\begin{array}{l}\text { Domestic } \\
\text { Net Imports }\end{array}$ & $\begin{array}{r}1,924 \\
14,488 \\
\end{array}$ & $\begin{array}{r}1,597 \\
13,383 \\
\end{array}$ & $\left(\begin{array}{l}2.3) \\
(.0) \\
0=0\end{array}\right)$ \\
\hline & Total Supply & 16,412 & 14,980 & (1.1) \\
\hline \multirow[t]{2}{*}{ Aluminà } & $\begin{array}{l}\text { Domest ic Prod'n } \\
\text { Net Imports }\end{array}$ & $\begin{array}{l}7,148 \\
1,531\end{array}$ & $\begin{array}{l}6,568 \\
3,404\end{array}$ & $\begin{array}{l}(0.0 y) \\
10.5\end{array}$ \\
\hline & Total Supply & 8,679 & 9,972 & 2.0 \\
\hline
\end{tabular}

Source: Mineral Industry Survey, Minerals Yearbook; Bureau of Mines 
The most significant change, in terms of oil shale based alumina, is that the composition of contained alumina imports have shifted away from the lower value alumina raw material, bauxite, to the comparatively expensive finished alumina.

In 1974 The International Bauxite Association (IBA) was formed, with Jamaica a founding member. The apparent objective of the IBA was to emulate OPEC by forming a bauxite producing nation: cartel. A key elcment in this was control of bauxite mines by nationalization. This was initiated by Jamaica, and followed by some of the other members. 12) Australia has not followed the cartel pricing and practices. However, the effect upon U. S. imports of this attempt to cartelize aluminum industry bauxite sources was that Australia became the primary source of alumina imports for the U.S., and Jamaican alumina exports dropped sharply.

The economic impact upon primary producers, however, was severe because the cost of raw materials for smelters rose concurrently with electric power costs. The latter increased particularly rapidly wherever the power was based upon fossil fuels, such as in the TVA region. From 1970 to 1977 the cost patterns for imported bauxite and alumina were reported as follows:

TABLE 3.15

$$
\begin{gathered}
\text { Historical Values of Imported Bauxite } \\
\text { and Alumina for Primary Metal }
\end{gathered}
$$

\begin{tabular}{|c|c|c|c|c|c|}
\hline \multirow[b]{2}{*}{ Commodity } & \multirow[b]{2}{*}{ Item } & \multirow[b]{2}{*}{ Units } & \multicolumn{2}{|c|}{ Dollars } & \multirow{2}{*}{$\begin{array}{l}\text { Annual } \\
\text { Change }\end{array}$} \\
\hline & & & 1970 & 1977 & \\
\hline Crude \& Dried Bauxite ${ }^{1)}$ & Avg Price. & Long Ton & 12.39 & 30.74 & 13.9 \\
\hline & Total Cost & Millions & 160.3 & 393.0 & 13.7 \\
\hline Cell Grade Alumina & Avg Price ${ }^{2)}$ & Short Ton & 59.70 & 123.62 & 11.0 \\
\hline & Total Cost & Millions & 152.5 & 512.4 & 18.9 \\
\hline
\end{tabular}

$\frac{1970-1978}{19070}$

1) Average value $F O B$ port of shipment, for alumina production

2) Weighted average, $F O B$ port of shipment

Source: Mineral Industry Survey, Minerals Yearbook; Bureau of Mines

The effect on U. S. balance of payment for primary aluminum raw materials was dramatic: The total cost of bauxite and alumina imports 
intended for primary aluminum production rose from $\$ 313$ million dollars in 1970 to $\$ 905$ million in 1977 , a compounded annual increase of $16.4 \%$.

Much of this increase can be attributed to the higher tax imposed by Jamaica, which is based upon the following formula:

TABLE 3.16

Jamaican Bauxite Tax Formula

$\left(P_{a} \cdot T\right) \frac{(2000)}{(4.3)}=$ Tax per Long Ton of Bauxite

$\mathrm{P}_{\mathrm{a}}=$ Average Domestic Price per Pound of Primary Aluminum in U.S.

4.3 = Tons of Jamaican Bauxite required per Ton of Primary Aluminum

$T=$ Levy per Long Ton of Bauxite, 0.075 in 1977

Source: Bell Journal of Economics, "Cartel Pricing and the Structure of the World Bauxite Market" Robert S. Pyndyck, Autumn 1978

ris

Assuming an average 1979 primary aluminum price of $\$ 0.57 / 1 \mathrm{~b}$ or $\$ 1140 /$ Short Ton, the tax cost alone for Jamaican bauxite would be:

$(\$ 0.57 \times 0.075)(464.12)=\$ 19.88$ LT of Bauxite

According to the Mineral Industries Survey, Bureau of Mines, approximately 6.34 million long tons of bauxite were imported into the U. S. from Jamaica in 1978; using the preceding formula and levy, this was equivalent to approximately $\$ 143$ million in tax to Jamaica alone. The other members of the IBA at the time of its formation in November 1974 were:

TABLE 3.17

International Bauxite Association Membership

Nation

Australia

Dominican Republic

Ghana

Guyana

Haiti

Indonesia*

Jamaica

Sierra Leone

Sur inam

Yugos lavia
Region

Oceania

Caribbean

Africa

S. America

Caribbean

S. E. Asia

Caribbean

W. Africa

S. America

E. Europe

*Admitted subsequent to founding members

Source: Minerals Yearbook, Bureau of Mines 
Australia had not increased its levy in the same proportion as the other members as of 1978, and further data have not been reported.

Foreign trade thus can be a major economic factor in oil shale mineral recovery, particularly with respect to alumina. Alumina's higher implied values make it nearly as influential as the soda ash in mineral recovery economics, as well as an important potential for reducing imports of foreign raw materials.

Caustic soda and alumina are important links in world alkali balances (sodium oxide based materials such as soda ash and caustic soda are commercially known as alkalis), because of the use of sodium hydroxide in the Bayer process to extract alumina from bauxite. This requires between 110-280 pounds of caustic soda per short ton of alumina. ${ }^{13)}$ World alumina production in 1978 was reported as 19,976,000 metric tons, equivalent to approximately 2.5 million short tons of caustic soda, the coproduct of 2.3 million tons of chlorine.

World Alumina Production

Production trends for the major producing nations between the years 1969 and 1978 can be seen in the following table:

TABLE 3.18

Ranked Alumina Requirements for Primary Aluminum Production in Selected Producing Regions or Nations $1969-1978$

Thousands Short Tons

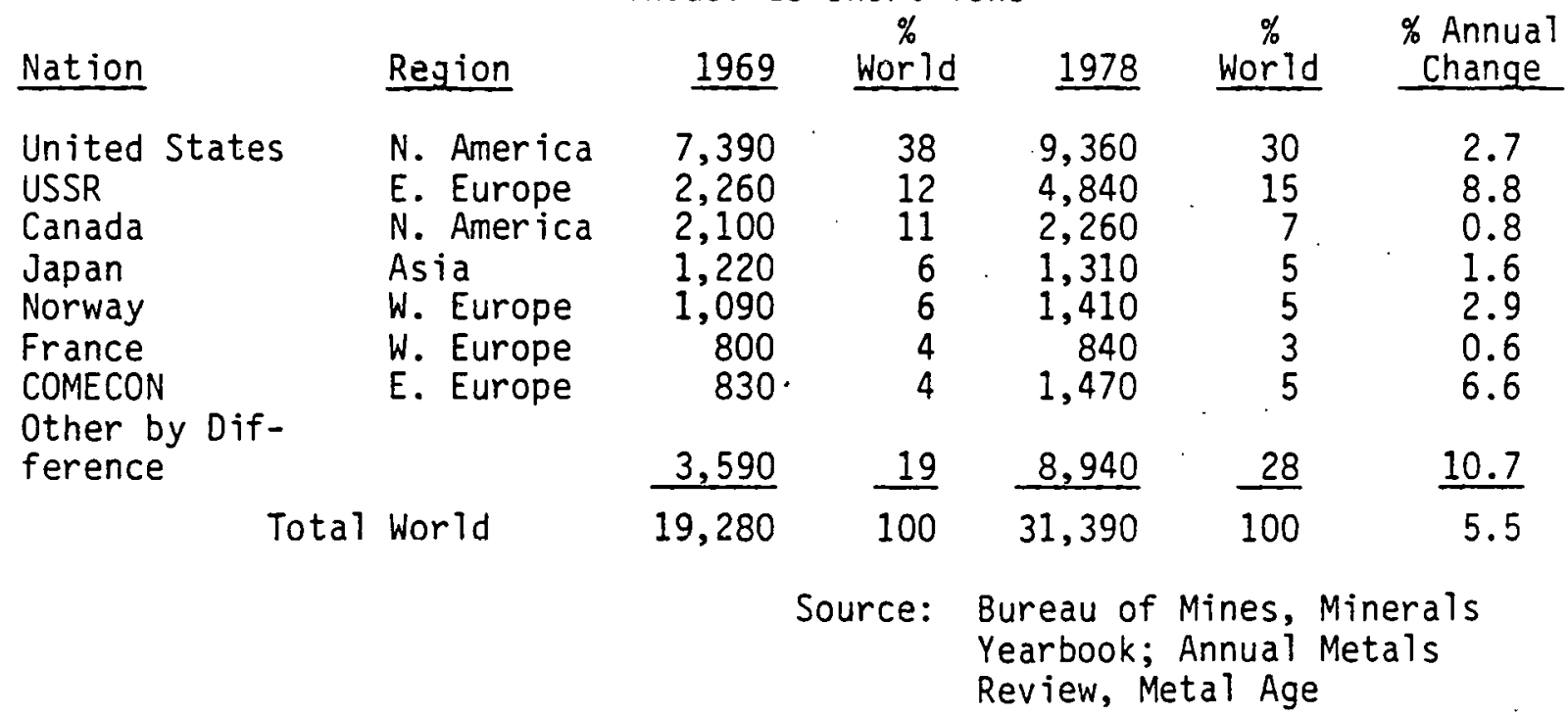


World Caustic Soda Production

Caustic soda output for major producing areas of the world are reported as follows:

TABLE 3.19

Reported Caustic Soda Production for Selected Nations Thousands of Short Tons 1969-1978

\begin{tabular}{|c|c|c|c|c|}
\hline \multirow[b]{2}{*}{ Nation } & & \multirow{2}{*}{$\begin{array}{l}\% \text { Annual } \\
\text { Change }\end{array}$} \\
\hline & Region & 1969 & 1978 & \\
\hline United States & North America & 9,910 & 10,710 & 0.9 \\
\hline Japan & Asia & 2,430 & 3,060 & 2.6 \\
\hline USSR & East Europe & 1,840 & 3,050 & 5.8 \\
\hline West Germany & West Europe & 1,700 & 3,670 & 8.9 \\
\hline France & West Europe & $1,1.50$ & 1,630 & 1.5 \\
\hline Other & World & 6,180 & 7,880 & 2.7 \\
\hline & & $23 ; 210$ & 30,000 & 2.9 \\
\hline
\end{tabular}

Source: Statistical Yearbook United Nations; Chemical \& Engineering News, June 9, 1980

As can be seen by comparing tables 18 and 19 , the world caustic supply is increasing at approximately $53 \%$ of the rate of alumina demand, based upon reported data. More important, caustic demand, or its equivalent as soda ash, for alumina production is increasing most rapidly in Australia and the COMECON countries.

While caustic demand from alumina production amounts to only $4 \%$ of U.S. output, and about the same for Japan, in the case of Australia it is several times the estimated 1978 caustic soda production.

The bulk of the imported material is reported by trade sources to come from Japan and U. S. Gulf Coast producers.

Jamaica likewise imports its caustic requirements through Jamaican bauxite based U. S. primary aluminum producers who own captive caustic-chlorine plants in the U.S. Based upon reported world caustic and alumina production, alumina recovery accounts for approximately $9 \%$ of all caustic soda demand. 
As can be seen from these summarized tables, if caustic output continues its relatively slow growth, and alumina maintains its rates, any shortfall would be likely to have to be made up by soda ash substitution, assuming all other uses remain the same for caustic.

At present non-U. S. alumina producers are not believed to be in a position to utilize soda ash because of the need for lime kilns and dry product handling facilities, but should caustic soda rise appreciably in price, and ash remain relatively stable, it is possible that plants based upon caustic soda could switch. The factors most likely to determine this would be:

* availability and cost of high grade lime;

* fuel availability and cost for the lime kilns;

* cost of dry handling facilities;

* the differential between ash and caustic soda oxide costs;

* the permanence of the trends.

The potential for complementary trade in alumina and soda ash exists in the ratio of about one ton of ash to 13 tons of alumina.

C. ALUMINA AND SODIUM OXIDE END USES AND ECONOMICS

1. Alumina

\section{Production Raw Materials}

Alumina (aluminum oxide $\mathrm{Al}_{2} \mathrm{O}_{3}$ ) is an abundant component of the earth's crust, comprising about $16 \%$ on an $\mathrm{Al}_{2} \mathrm{O}_{3}$ basis. ${ }^{14)}$ Commercially it is produced almost exclusively from bauxite, which contains about $55 \%$ $\mathrm{Al}_{2} \mathrm{O}_{3}$. The remaining constituents are primarily iron, silica and moisture. Typical bauxite specification for cell grade alumina are shown in the table following. The most important constituent, as discussed previously, is silica, because of its ability to tie up both sodium and alumina on nearly a pound for pound basis of each. The next most critical specification is the alumina content because of its effect on both freight and, plant production capacity. Moisture is a factor to the degree that its removal is a significant cost when fuel is expensive, as in Jamaica. 
TABLE 3.20

Typical Bauxite Specification for Cell Grade Alumina Weight Percent

\begin{tabular}{|c|c|c|c|c|}
\hline & & & Source & \\
\hline Component & Formula & Boke' & Brazí & Guyana \\
\hline Alumina & $\mathrm{Al}_{2} \mathrm{O}_{3}$ & 58.50 & 55.39 & 55.00 \\
\hline Silica & $\mathrm{SiO}_{2}$ & 0.63 & 4.42 & 4.25 \\
\hline Moisture & $\mathrm{H}_{2} \mathrm{O}$ & 3.00 & 3.00 & 15.00 \\
\hline
\end{tabular}

The chemical composition of the largest U. S. source of bauxite, Jamaica, is shown below:

TABLE 3.21

Chemical Composition of Jamaican Bauxite Dry Bas is

Component

Alumina

Hematite (Ferric Oxide)

Silica

Ignition Loss (Hydrates)

Titania

Other

Total
Formula Weight Percent

$\begin{array}{cr}\mathrm{Al}_{2} \mathrm{O}_{3} & 49.0 \\ \mathrm{Fe}_{2} \mathrm{O}_{3} & 20.0 \\ \mathrm{SiO}_{2} & 2.5 \\ \mathrm{H}_{2} \mathrm{O}^{2} & 25.0 \\ \mathrm{TiO}_{2} & 2.5 \\ - & 1.0 \\ & 100.0\end{array}$

Source:

Because Jamaica is by far the largest supplier of bauxite to the U. S., its composition is of considerable importance to chemical markets. As can be seen, its alumina content is lower than one from Boke' (New Guinea), Brazil or Guyana, but its silica content is also. The most important consideration is its proximity, which offsets the other disadvantages. 
There are other alumina containing minerals which have been examined in varying detail for their potential as a non-bauxitic source of alumina. Some of these are:

$$
\begin{aligned}
& \text { Alunite }-\mathrm{K}_{2} \mathrm{Al}{ }_{6}(\mathrm{OH})_{12}\left(\mathrm{SO}_{4}\right)_{4} \\
& \text { Anorthosite - Alumina-Silicate } \\
& \text { Kaolin Clay - } \mathrm{Al}_{2} \mathrm{O}_{3} \cdot 2 \pm . \mathrm{SiO}_{2} \cdot 2 \mathrm{H}_{2} \mathrm{O}
\end{aligned}
$$

The primary basis for these investigations, some of which go back to World War II, was security of supply for the aluminum industry in the event of inability to get Jamaican or South American bauxite. Earth Sciences, Southwire and National Steel were reported as working on a process based upon their Utah alunite reserves. ${ }^{15)}$

An experimental plant is reported to have been built in Salamanca, Mexico based upon alunite with potassium sulfate a by-product for fertilizer use. ${ }^{16)}$ It is not known if this facility is still operating.

All of the non-bauxitic processes suffer from their lower alumina contents in comparison to bauxite:

$$
\begin{aligned}
& \frac{\text { Mineral }}{\underline{\text { Bauxite }}}-\frac{\mathrm{Al}_{2} \mathrm{O}_{3} \text { of chemical constituent }}{49-58} \\
& \text { Alunite }-37 \\
& \text { Kaolinite - } 40
\end{aligned}
$$

Source: Handbook of Chemistry, Lange; Bell Journal of Economics, Autumn 1977, "Cartel Pricing and Structure of the World Bauxite Market"

The percentages cited, other than for bauxite, do not reflect the as-mined alumina content of the ore, but rather that of the basic alumina bearing mineral. The actual prepared feed to a recovery plant would have a lower $\mathrm{Al}_{2} \mathrm{O}_{3}$ content due to the presence of other minerals in the ore. The latter tends to reduce the effective $\mathrm{Al}_{2} \mathrm{O}_{3}$ content by about $30 \%$ from the percentages shown in the table. Because of these unfavorable $\mathrm{Al}_{2} \mathrm{O}_{3}$ ratios in comparison to bauxite, alternative sources have not proven to be economic so far.

Bauxite consumption in the United States is predominantly for alumina production. End uses of bauxite are shown in the table on the following page. 
TABLE 3.22

U. S. Consumption of Bauxite by End Use $1970-1979$

Thousands of Metric Tons

\begin{tabular}{|c|c|c|c|c|c|}
\hline End Use & 1970 & $\%$ & 1979 & $\%$ & $\begin{array}{c}\% \text { Annual } \\
\text { Change in Tonnage }\end{array}$ \\
\hline Alumina & 14,950 & 93.5 & 14,524 & 92.5 & $(0.3)$ \\
\hline Abrasives & 290 & 1.8 & 327 & 2.1 & 1.3 \\
\hline Chemical & 310 & 1.9 & 256 & 1.6 & $(2.1)$ \\
\hline Refractory & 380 & 2.4 & 520 & 3.3 & 3.6 \\
\hline Other & 60 & 0.4 & 70 & 0.5 & 1.7 \\
\hline Total & 15,990 & 100.0 & 15,697 & 100.0 & $(0.2)$ \\
\hline
\end{tabular}

Imported bauxite comprised all but $10 \%$ of the supply, most of which was used for alumina. Domestic production, due to its high silica content, has tended to be used for other applications such as refractories, chemicals or abrasives where the silica content is not a process problem.

Major sources of bauxite in the United States were as follows:

TABLE 3.23

U. S. Sources of Bauxite for Consumption

\begin{tabular}{|c|c|c|c|c|c|}
\hline Source & 1970 & $\%$ & 1979 & $\%$ & $\begin{array}{c}\% \text { Annual } \\
\text { Change in Tonnage }\end{array}$ \\
\hline Domestic & 2,110 & 14.1 & 1,810 & 11.7 & $(1.6)$ \\
\hline Australia & 920 & 6.2 & N. R. & N. R. & N. A. \\
\hline Jamaica & 7,630 & 51.1 & 6,470 & 41.5 & $(1.8)$ \\
\hline Surinam & 2,970 & 19.9 & 1,520 & 9.7 & $(7.2)$ \\
\hline Other & 1,300 & 8.7 & 5,790 & $3 \% .1$ & 18.5 \\
\hline Total & 14,930 & 100.0 & 15,600 & 100.0 & 0.5 \\
\hline
\end{tabular}


The bulk of domestic production came from Arkansas, which accounted for $90 \%$ of U. S. bauxite output in 1970. Reported bauxite values for the comparable period were:

TABLE 3.24 .

Average Reported Values of Crude Dried Bauxite from Selected Foreign and Domestic Sources \$/Metric Ton

\begin{tabular}{lllllc} 
Source & Basis & $\underline{1970}$ & $\underline{1977}$ & $\underline{1979}$ & $\begin{array}{c}\text { \% Annual } \\
\text { Change }\end{array}$ \\
\cline { 2 - 5 } U. S. Domestic & As Shipped & 13.60 & 11.79 & 13.66 & - \\
Imported, a11 & FAS $^{1)}$ & 12.60 & 25.73 & 25.46 & 8.1 \\
Jamaica & FAS $^{1)}$ & 13.20 & 27.95 & 28.10 & 8.7 \\
Australia & FAS & $10.85^{2}$ & N. R. & N. R. & -
\end{tabular}

1) Port of Shipment

2) 1971 Data; none reported 1970

Source: Mineral Industries Survey, Minerals Yearbook, Bureau of Mines

One of the most critical components in the bauxite feed to a Bayer process alumina plant is silica, since each ton will tie up one ton of alumina and about 0.6 ton of sodium oxide (one ton of soda ash). 17) The other consideration in the bauxite feed is whether the alumina is in the form of monohydrate $\left(\mathrm{Al}_{2} \mathrm{O}_{3} \cdot \mathrm{H}_{2} \mathrm{O}\right)$ or trihydrate $\left(\mathrm{Al}_{2} \mathrm{O}_{3} \cdot 3 \mathrm{H}_{2} \mathrm{O}\right)$, the latter being more easily dissolved than the former. The significance is that higher caustic soda concentrations are required for the monohydrate bauxite ore, the usual feed to European plants. ilamaican ore also contains a mixture of trihydrate and monohydrate, and so tends to have a higher caustic requirement than ores with a lower monohydrate content. The pri-' mary economic drive for use of Jamaican bauxite is the proximity of Jamaica to the U.S. Gulf Coast ports, plus worldscale reserves (apprnximateply two billion long tons).

The average silica content of domestic mine production has been increasing, so that utilization of these reserves requires a separate limc sinter loop. This step utilizes soda ash to precipitate the silica as dicalcium silicate. ${ }^{18)}$ There are two U. S. alumina plants in Arkansas, both of which have been closed until recently. The likelihood of renewed 
operations is increasing, however, due to increases in rail freight rates and foreign bauxite costs.

Bayer Process for Alumina Production

The Bayer process for production of alumina consists of the following steps and conditions:

\section{TABLE 3.25}

\section{Bayer Process Sequence for Alumina Production}

Step

Bauxite Grinding

Pressure Digestion

Clarification

Precipitation

Calcination

Spent Liquor Recovery

Procedure and Process Conditions

Feed ground to minus 20 mesh, recovered spent 1 iquor added 200 Psig, $400^{\circ} \mathrm{F}, 30$ minutes

Starch added, liquor filtered through leaf filters

Filtrate cooled to $160^{\circ} \mathrm{F}$, trihydrate fines added as seed to precipitate alumina trihydrate

Precipitate is filtered, washed and calcined at $2100 \mathrm{~F}$ in rotary $\mathrm{kiln}$

The precipitator filtrate is concentrated, and caustic makeup added, either as caustic or soda ash and lime.

Source: Cost Estimate, Bureau of Mines; Chemical Process Industries, R. Norris Shreve.

Alumina production by the Bayer process is an important link in world sodium oxide balances because of the existing caustic soda requirements for digestion. In addition, there is the potential for use of soda ash to reprocess the red mud pile ( $p$ lant tailings) for entrained sodium oxide and alumina tied up by silica. With increasing values for both alumina and caustic, this could be a significant potential use of soda ash.

When bauxite, fuel and caustic soda were inexpensive, it was not economic to recover the entrained material rejected with the digester solids as red mud. (The primary constituents of the red mud are iron, silica, calcium and oxygen compounds. The iron confers the distinct reddish color.)

Bayer process imputed direct production costs are shown in the table following. These costs do not reflect return on invested capital, taxes and insurance or other injirect ex.enses.

E. G. HIGGINS FEDERAL 
TABLE 3.26

Imputed Domestic Alumina Direct Production Costs

\begin{tabular}{|c|c|c|c|}
\hline$\underline{\text { Item }}$ & Units & Requirements & $\begin{array}{c}\text { Estimated } \\
\text { Cost/Ton of } \\
\text { Alumina } \\
\end{array}$ \\
\hline Bauxite & Short Tons & 2.4 & $\$ 35.52^{1)}$ \\
\hline Limestone & Pounds & 148 & 0.30 \\
\hline Soda Asin & Pounds & 150 & $8.03^{21}$ \\
\hline Starch & Pounds & $12^{3)}$ & $1.10^{3)}$ \\
\hline Electricity & Kwhr & 71 & $2.84^{4)}$ \\
\hline Steam & Pounds & 2700 & $6.75^{5)}$ \\
\hline Natural Gas & MCF & 4.9 & $13.66^{5)}$ \\
\hline Cooling \& Process. Water & Thous. Gal. & 4.7 & 2.35 \\
\hline Labor & Man Hours & 5.6 & $56.00^{6)}$ \\
\hline \multicolumn{2}{|c|}{ Total - Direct Costs Only } & & $\$ 125.14$ \\
\hline \multicolumn{4}{|c|}{$\begin{array}{l}\text { 1) Basis } \$ 14.80 / M T \text { U.S. Bauxite Price CIF Plant } \\
\text { 2) at } \$ 107 / \text { Ton Delivered } \\
\text { 3) at } \$ 180 / \text { Ton } \\
\text { 4) at4 } \$ / K W h \\
\text { 5) at } \$ 2.5 / M M \text { BTUs }\end{array}$} \\
\hline
\end{tabular}

Sourçe: Cost Estimate of the Bayer Process for Producing Alumina - Peters, Johnson \& Kirby, Bureau of Mines

As can be seen, bauxite, excluding the levy on foreign ore, is $28 \%$ of the direct cost of alumina, while energy related components accounted for about $17 \%$. The largest cost sector was labor, at $45 \%$. This is also the least controllable expense, since alumina plants are labor intensive because of maintenance requirements.

According to the basic study made by Peters, Johnson and Kirby of the Bureau of Mines in 1965, the original cost of labor was approximately $17 \%$ of the cost of alumina, while energy related components were around 15\%, only slightly lower than in 1979 estimates. Bauxite, however, was almost $58 \%$ of direct costs at the time. Fixed and indirects were estimated to be about $25 \%$ of the whole cost of alumina manufacture in 1965 , 
including taxes and depreciation. It is unlikely tinat ihis cost would be more than $\$ 10-\$ 15 /$ ton in the U. S. in 1979 because the plants are all depreciated. In 1977 the BuMines estimated a new plant would cost $\$ 500 /$ annual ton.

A major expense not applicable to alumina in 1965 was the levy of $7.5 \%$ of the published ingot aluminum price on the aluminum content of Jamaican bauxite. In 1979, if applied at the 1974 rates, it would amount to approximately $\$ 52$ per ton of alumina.

Based upon a summing up of the previous extrapolations of the Bureau of Mines study, U. S. alumina would be estimated to cost $\$ 190 / 200$ per ton, using Jamaican bauxite. This combines a U. S. mine price of $\$ 13.66$ for bauxite, plus $\$ 15$ per ton for fixed and indirect costs and $\$ 52$ per ton Jamaican levy. A projected alumina plant in Bintan, Indonesia, reported estimated costs of $\$ 225 /$ metric ton, while Japan reported an ability to purchase at $\$ 180$ per ton. ${ }^{19)}$

The alumina cost per ton of primary aluminum, using \$190per ton of alumina as a base, would be $\$ 371$ per ton of primary metal, excluding freight.

Freight is an important component of alumina economics to a smelter since 1.95 tons of alumina are required per ton of primary aluminum metal. Figure 3 shows the location of primary aluminum smeltors and alumina plants in the U.S.

As can be seen, the bulk of smelter capacity is in the Northwest, Southwest and TVA areas because of their originally favorable energy costs. The Southwest is no longer a cheap energy area and may be suffering power shortages within the decade, while the Northwest has plans to increase power rates from their present level of 3 Mils to 6 Mils by December $20,1979.20)$ Other regions have been unable to commit the power necessary to justify new potlines (primary smeltors). ${ }^{21}$ ) While the Northwest power rates are rising, they are still far lower than elsewhere, and this differential will increase.

All of the U. S. alumina capacity is located in the South and Southwest, and moved to smeltors close to power sources and markets, usually by ship or barge. An alumina source, such as oil shale, located 
closer to smeltors with favorable power costs could have significant advantage because of the role of freight in alumina economics, as is shown more graphically in Figure 3.

Some alumina finished production is in the form of trihydrate, which has been lightly calcined to dry the trihydrate without decomposing to aluminum oxide. One of the growing applications of trihydrate is as a fireproofing additive to textiles and furniture. The trihydrate decomposes to water and alumina as the temperature of a fire rises, thereby limiting or extinguishing the fire.

All uses of alumina, other than as cell grade primary metal and feedstock, are minimal and of no significance to sodium oxide $\left(\mathrm{Na}_{2} \mathrm{O}\right)$ demand or dawsonite recovery economics. Alumina demand, therefore, can be directly equated to primary metal production and demand worldwide.

Markets

World Supply

In the context of the market for oil shale based alumina, the production of primary aluminum is the number of merit. Primary aluminum, however, competes with other metals such as magnesium or copper, where high thermal conductivity, favorable strength to weight ratios or other desirable properties exemplified by aluminum are present. One of the most important new competitors for primary aluminum is secondary, or recovered, aluminum from scrap.

The importance of this to alumina markets will be discussed later.

Primary aluminum is produced in virtually all of the industrialized nations of the world, and many of the developing nations with large bauxite reserves and cheap hydroelectric power or flare gas.

The primary nations where major smelter expansions are planned are:

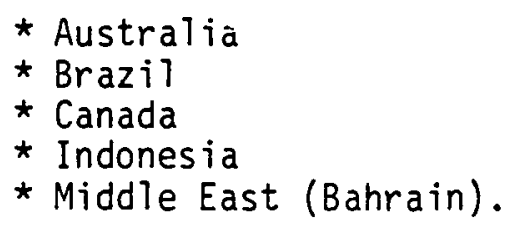


World production of aluminum, by major area, can be seen in the table following:

\section{TABLE 3.27}

World Primary Aluminum Production by Major Region Thousands of Metric Tons

\begin{tabular}{|c|c|c|c|c|c|}
\hline Region & 1970 & $\%$ & $\underline{1978}$ & $\%$ & $\begin{array}{l}\% \text { Annual Change } \\
\text { In Production }\end{array}$ \\
\hline North America & 4,580 & 47.5 & 5,406 & 37.2 & 2.1 \\
\hline Western Europe ${ }^{1)}$ & 1,970 & 20.4 & 3,247 & 23.0 & 6.9 \\
\hline Asia ${ }^{2)}$ & 937 & 9.7 & 1,510 & 10.4 & 6.2 \\
\hline Oceania & 204 & 2.1 & 415 & 2.9 & 8.2 \\
\hline Eastern Europe 3 ) & 1,505 & 15.6 & 2,686 & 18.5 & 7.5 \\
\hline Other ${ }^{4)}$ & $450^{\circ}$ & 4.7 & 1,168 & 8.0 & 12.7 \\
\hline Total & 9,646 & 100.0 & 14,532 & 100.0 & 5.3 \\
\hline
\end{tabular}

1) Excluding Yugoslavia, includes Iceland

2) Includes India, Middle East and Turkey

3) Includes Yugoslavia, USSR, China

4) South America, Africa (by difference)

Source: World Bureau of Metal Statistics; Bureau of. Mines, Minerals Yearbook

As can be seen, the highest growth rates for primary aluminum production have been in Eastern Europe and Oceania (Australia/New Zealand), but the largest absolute increases in tonnage were in Western Europe and Eastern Europe respectively. The third largest was North America (U. S. and (anada) which remained the largest end user of alumina.

Regional primary aluminum production, however, is dominated by a relatively small number of nations. This is largely a consequence of the importance of markets to early aluminum economics, so that the major industrialized nations with large consuming industries, such as aircraft, or low cost energy, such as Canada, installed the capacity. 
TABLE 3.28

Ranked Major Primary Aluminum Producing Nations Thousands of Metric Tons

\begin{tabular}{|c|c|c|c|c|c|c|}
\hline Nation & Region & 1970 & $\begin{array}{c}* \\
\text { World }\end{array}$ & 1978 & $\begin{array}{c}\% \\
\text { World } \\
\end{array}$ & $\begin{array}{l}\text { \% Annual } \\
\text { Production } \\
\text { Change } \\
\end{array}$ \\
\hline U. S. & N. America & 3,608 & 37.4 & 4,358 & 30.0 & 2.4 \\
\hline U.S.S.R. & E. Europe & 1,100 & 11.4 & 3,248 & 15.1 & 8.0 \\
\hline Japan & Asia & 733 & 7.6 & 1,058 & 7.3 & 4.7 \\
\hline Canada & N. America & 973 & 10.1 & 1,049 & 7.2 & 0.9 \\
\hline W. Germany & W. Europe & 309 & 3.2 & 740 & 5.1 & 10.6 \\
\hline Norway & W. Europe & 530 & 5.5 & 657 & 4.5 & 2.7 \\
\hline Other & - & $\underline{2,393}$ & 24.8 & 4,470 & 30.8 & 8.1 \\
\hline \multirow{2}{*}{\multicolumn{2}{|c|}{ Total. }} & 9,646 & 100.0 & 14,532 & 100.0 & 5.2 \\
\hline & & $S$ & $\begin{array}{l}\text { Wor } \\
\text { Mine }\end{array}$ & $\begin{array}{l}\text { eau } \\
\text { Yea }\end{array}$ & $\begin{array}{l}\text { eta } \\
\text {, B }\end{array}$ & $\begin{array}{l}\text { istics; } \\
\text { of Mines }\end{array}$ \\
\hline
\end{tabular}

In terms of alumina, if the U.S. S. R. reported aluminum production is excluded from the above totals, five nations accounted for $54 \%$ of the world cell grade alumina demand.

World alumina production, however, is not distributed in the same manner. Alumina plants are typically located on water or proximate to. bauxite mines to reduce the freight costs, since $2.15 \mathrm{LT}$ of bauxite are used, on average, per ton of alumina. Smelters are located according to power, availability and cost. Smelters are also located by navigable water whenever possible in order to utilize ship and barge movement of alumina and thereby reduce freight costs.

Alumina has been moved via unit train hu pronlucers from the Gulf Coast to the Northwest aluminum smelters, but risina freiaht costs appear to favor ocean move via the Panama Canal or imports from Australia. Intracompany product movements are not normally matters of public record except as locally published dockings. With the deregulation of rail freight rate setting procedures, it is possible that existing rates for alumina will increase substantially, although this is by no means certain. Current rates are believed to be "water compelled", or controlled by the alternative cost of water movement. 
The effect is to locate smelters in user countries and alumina plants in bauxite producing regions, as can be seen in the following table.

TABLE 3.29

Alumina Production and Demand for Use in Primary Smelters

Thousands of Metric Tons

Region 1970

North America

Supply Smelter Use 3)

$\frac{1977}{\text { Supply Smetter Use 3) }}$

Western Europe

$9,280^{1)}$

8,930

9,160

9,980

Asia

2,620

3,840

3,810

7,430

Oceania

1,650

1,830

2,410

3,120

2,140

400

6,690

760

Eastern Europe

$$
2,720
$$

$\frac{2,290^{2}}{20,700}$

2,940

4,420

4,520

Other ${ }^{2)}$

$\frac{870}{18,810}$

$\frac{2,920}{29,410}$

$\frac{830}{26,640}$

1) Includes Jamaica

2) Includes Surinam

3). Equivalent for primary only

Source: Minerals Yearbook, Bureau of Mines, Metals Bulletin

Using the ratio of 1.95 tons of $\mathrm{Al}_{2} \mathrm{O}_{3}$ feed to one ton of primary aluminum metal, it can be seen that North America is the largest balanced primary aluminum market in the world. A somewhat different picture emerges when the component nations are reported separately, especially with respect to Jamaica and Australia. Both are major alumina producers, but have either no smelter capacity or very little, as in Australia. The Caribbean and South American producers bordering on the Caribbean Sea have historically been operated essentially as an integrated unit, with the smelters located in the U. S. because of the low power costs and proximity to market. Where bauxite was upgraded to alumina in the host country, the caustic source was usually a U. S. Gulf coast caustic/chlorine plant.

When the bauxite supplying nations such as Jamaica and Guyana embarked upon a policy of requiring more of the value added income for bauxite by means of taxation, the economics of alumina began to change significantly, with a general benefit to oil shale recovery economics. The effect upon world alumina production can be seen in the table on the following page. 
TABLE 3.30

Ranked Major Alumina Producing Nations

Thousands of Metric Tons

\begin{tabular}{|c|c|c|c|c|c|}
\hline Nation & 1970 & $\%$ & 1977 & $x$ & $\begin{array}{l}\text { \% Annual } \\
\text { Production } \\
\text { Change } \\
\end{array}$ \\
\hline Australia & 2,139 & 10.3 & 6,659 & 22.6 & 17.6 \\
\hline United States & 6,486 & 31.3 & 6,033 & 20.5 & $(1.0)$ \\
\hline U. S. S.R. & 1,815 & 8.8 & 2,631 & 8.9 & 5.4 \\
\hline Jamaica & 1,690 & 8.2 & 2,036 & .6 .9 & 2.7 \\
\hline Japan & 1,285 & 6.2 & 1,785 & 6.1 & 4.8 \\
\hline West Germany & 758 & 3.7 & 1,397 & 4.8 & 9.1 \\
\hline Other & 6,528 & 31.5 & 8,869 & 30.2 & .4 .5 \\
\hline \multirow[t]{2}{*}{ Total } & 20,701 & 100.0 & 29,410 & 100.0 & 5.2 \\
\hline & & & Source: & $\begin{array}{l}\text { Metals } \\
\text { Yearbool }\end{array}$ & $\begin{array}{l}n \text {, Minerals } \\
\text { au of Mines }\end{array}$ \\
\hline
\end{tabular}

of the major aluminum and alumina producing nations, only the U. S. has actually produced less, although increasing primary aluminum production. To accomplish this, as shown earlier, the U. S. greatly increased alumina imports. The impact upon U. S. balance of payments, as discussed in the section under World Trade, has been adverse and is like$l y$ to become more so.

The implications to recovery of alumina from oil shale is quite encouraging from a balance of payments viewpoint, especially if the production costs are in line with current Bayer process economics. One of the most important benefits, in addition to reducing imports, would be that costs of alumina would no longer be subject to external politically determined pricing. In terms of security of supply for a critically important engineering material, oil shale based alumina would have the effect of making the U.S. a minor, rather than major, foreign alumina market.

Australia, as the dominant (40\%) supplier of the free world bauxite and alumina needs for primary aluminum, is gradually shifting this emphasis toward upgrading to metal, as stated earlier. ${ }^{22)}$ Australia furnished $75 \%$ of all U. S. alumina imports in 1979, so the U. S. is 
vulnerable to interruptions of a basic raw material required for aluminum production.

U. S. Alumina Supply, Demand and Price History

United States alumina supply, as shown previously, is heavily dependent upon imports as direct sources in the form of alumina imports, and indirect as bauxite imports. In aggregate, foreign sources account for nine out of ten tons of alumina used for primary aluminum production.

U. S. consumption of alumina is almost entirely a function of primary aluminum manufacture. The table following outlines the history of U. S. supply/demand relationships.

\section{TABLE 3.21}

U. S. Alumina Supply/Demand for Primary Aluminum, Selected Years

$\underline{1970}$

1979

\% Annual Change

$=\quad$ Alumina Supply

$\approx \quad$ Domestic

Imported Thousands of Short Tons

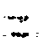

Total $\frac{2,555}{9,703} \quad \frac{4,520^{1}}{10,280}$

$\underline{6.6}$

0.7

Alumina Demand

For Primary Meta ${ }^{2}$

$\underline{7,750}$

9,790

2.7

Balance

Over (Under)

Supply 1,953

560

1) Estimate by Non-Ferrous Metals Division, Bureau of Mines

Source: Bureau of Mines, Minerals Yearbook; Mineral Industry Surveys

Alumina production in excess of domestic demand essentially was exported or traded for finished metal. 
Alumina imports were, by major source, as follows for 1970 and 1979:

TABLE 3.32

$\frac{\text { U. S. Alumina Imports - Selected Nations and Years }}{\text { Thousands of Short Tons }}$

$\begin{array}{lrrrrrc}\text { Nation } & \underline{1970} & \frac{\%}{47} & \underline{1979} & \frac{\%}{\%} & \begin{array}{c}\% \text { Annual } \\ \text { Change }\end{array} \\ \text { Australia } & 1,190 & 47 & 3,400 & 75 & 12.4 \\ \text { Jamaica } & 870 & 34 & 650 & 14 & (3.2) \\ \text { Surinam } & 350 & 14 & \text { N. R. } & & - \\ \text { Other } & \frac{140}{\quad \text { Total }} & 2,550 & \frac{5}{100} & \frac{\text { N. R. }}{4,520} & \overline{100} & \frac{-}{6.6}\end{array}$

Source: Bureau of Mines

The price history for the same period for alumina and primary metal was:

TABLE 3.33

Average Reported Values for Aluminum and Alumina in Selected Years, U. S.

\begin{tabular}{|c|c|c|c|}
\hline \multirow[b]{2}{*}{ Item } & \multicolumn{2}{|c|}{$\$ /$ Short Ton } & \multirow{2}{*}{$\begin{array}{l}\% \text { Annual } \\
\text { Change } \\
\end{array}$} \\
\hline & $\underline{1970}$ & $\underline{1977}$ & \\
\hline Dumestic Alumina & 70.50 & 139.00 & 7.9 \\
\hline Imported Alumina & 59.70 & 124.00 & 8.5 \\
\hline Weighted Average & 67.65 & 133.19 & 7.8 \\
\hline Primary Aluminum & 551.00 & $1,032.00$ & 7.2 \\
\hline
\end{tabular}

For the same period, the cost relationships between primary aluminum and average U. S. declared values for alumina were:

TABLE 3.34

Average Reported Unit Value

Relationship of Alumina and Primary Metal

Percent

Item

Alumina

A Tuminum

$\begin{array}{rr}\frac{1970}{12.3} & \frac{1977}{12.9} \\ 100.0 & 100.0\end{array}$

Source: Bureau of Mines Data 
If the alumina feedstock requirements per ton of primary metal are taken into account, alumina represents the following cost as a proportion of primary metal average and domestic price:

TABLE 3.35

Alumina Feedstock Costs per Ton of Primary Aluminum

\begin{tabular}{|c|c|c|c|c|c|}
\hline Item & $\begin{array}{l}\text { Tons } \mathrm{Al}_{2}{ }^{0}{ }_{3} \\
\text { per Ton Metal }\end{array}$ & $\underline{1970}$ & $\%$ & 1977 & $\%$ \\
\hline Alumina ${ }^{*}$ & 1.95 & $\$ 132$ & 24 & $\$ 260$ & 24 \\
\hline Aluminum & - & 551 & 100 & 1032 & 100 \\
\hline
\end{tabular}

Source: Minerals Yearbook, Bureau of Mines

If the same relationship were to be the case in 1980, the imputed value of alumina would be as seen below:

TABLE 3.36

Imputed Value of Domestic Alumina $\frac{\text { as a Percentage of Primary Aluminum Metal Price }}{\text { Aprịl } 1980}$

Item $\$$ \$ per Quoted Price of Aluminum Imputed Value of Alumina* Per Pound Short Ton.

*Basis: $12.3 \%$ of Aluminum Metal Price $\begin{aligned} & \text { Date Source: } \text { Mineral Industry } \\ & \text { Surveys, Bureau of } \\ & \text { Mines }\end{aligned}$

This figure is consistent with other reported values for long term alumina offerings to Japanese smeltors. ${ }^{23)}$ It is not known whether the prices referred to were delivered (CIF) or Port of Shipment (FAS).

If the rate of change in reported values for primary aluminum between 1970-1980 (9.1\%) were applied to alumina, the projected value of alumina in 1990 would be $\$ 414$ per short ton ( $\$ 456$ metric ton), basis 1977 prices. 
If projected at the average annual rate of change of weighted. average alumina values between 1970-1977, 7.8\% per year, 1990 imputed. values would be $\$ 354$ per short ton ( $\$ 390 /$ metric ton).

It should be noted that the average vaiues reported for imports are FAS port of shipment. The difference of approximately $\$ 15.00$ per ton from domestic average reported values is largely due to shipping.

If the domestic 1977 value of $\$ 139 /$ ton were used as a basis for projecting 1990 U. S. alumina values, and employing the 1970-1977. rate of change $(7.8 \%)$ for the projection, the resulting 1990 imputed value of alumina would be $\$ 370 /$ ton ( $\$ 407 /$ metric ton).

There was a reduction in the effective cost of imported alumina and bauxite in 1971, when all duties and tariffs applying to these materials were dropped. ${ }^{24)}$ This has not been taken into account in the aluminum economic comparison.

The range of values imputed to alumina as a function of primary aluminum prices thus can be quite wide, depending upon the basis used for the calculations. For the above cases, the range tabulated is as follows:

TABLE 3.37

$\frac{\text { Projectcd } 1990 \text { Imputed Values rur. Alumina }}{\text { S/Short Ton }}$

Basis

Aluminum Price Change 1970-1980 Alumina Price Change 1970-1977.

11

11

I1

Basis Rate 1977 Base Value Projected Value $\$ 133$ per Ton 9.1\% Weighted Avg \$414/Short Ton $7.8 \%$ $7.8 \%$

" $"$ " $\$ 354 / " ~ "$
$\begin{gathered}\$ 139 \text { per Ton } \\ \text { Domestic }\end{gathered}$

Source: E. G. Higgins Federal

The most logical value assumption is the first case, $\$ 414 /$ Ton, if it is assumed that the U.S. will continue to import the bulk of its alumina and bauxite from nations who have levies related to the market price of primary aluminum.

As power costs rise, and aluminum producers endeavor to recoup 
these costs by increasing the price of aluminum, the levy on foreign aluminum and bauxite will rise proportionately.

Alumina values, therefore, are most likely to rise as a function of aluminum prices rather than as a cost of manufacture for alumina, ex levies.

Obviously these values for alumina are not necessarily representative of what would be used by an integrated producer of primary metal, since there would be no real impact on total profits regardless of what price were used for alumina. It has a great deal of significance, however, to non-integrated smeltors or to ones with more smelter capacity than captive alumina supplies who must purchase their alumina.

Location also could play an important role in the value of the alumina from oil shale because of its intermediate distance to smelters from existing bauxite based alumina plants.

Whether this geographic advantage could be translated into an economic one cannot be determined at this point because of the complexity of U. S. alumina logistic costs.

Other End Uses of ATumina

Alumina trihydrate, the initial alumina plant process output, has a growing market as a fireproofing agent for textiles, but it is still an insignificant demand in comparison to primary aluminum.

Alumina is also used in the production of abrasives and ceramics employed in high temperature or severe wear applications. These uses are fairly small in comparison to cell grade alumina, amounting to about $3 \%$. of U.S. consumption.

Chemical uses were primarily to produce aluminum fluxes (cryo1ite) required for production of aluminum, and which accounted for about $50 \%$ of all alumina not directly used as cell feed for aluminum.

\section{Competitive Materials}

As has been shown, the overwhelming end use of alumina is for the manufacture of primary aluminum. The markets for alumina, then, are 
indirectly those for primary aluminum. Many of the end uses of aluminum, however, can be served as well by secondary metal recovered by recycling of cans, scrap and other secondary sources.

The history of primary and secondary aluminum production is seen in the following table.

TABLE 3.38

Salient Statistics for Domestic Aluminum

\begin{tabular}{|c|c|c|c|}
\hline Item & 1970 & $\underline{1979}$ & $\begin{array}{l}\% \text { Annual } \\
\text { Change }\end{array}$ \\
\hline Primary Production & 3,976 & 5,023 & 2.6 \\
\hline Secondary Recovery & .781 & $\underline{1,777}$ & 9.6 \\
\hline Total Production & 4,757 & 6,800 & 4.0 \\
\hline Exports & 612 & 233 & $(10.1)$ \\
\hline Imports & 468 & 772 & $\underline{5.7}$ \\
\hline Apparent Consumption & 4,519 & 7,339 & 5.6 \\
\hline
\end{tabular}

Source: Minerals Yearbook, Mineral Industry Surveys, Bureau of Mines

During tlie per iud 1970-1979, secondary àlumınum has gone from $16 \%$ of total domestic production of metal to $26 \%$. In effect, increased recovery of secondary metal has effectively removed the demand for nearly two million tons of alumina from the U.S. market.

During the same period, the U. S. went from a net exporter of aluminum to a net importer, following the same trend as alumina. In ef fect, the United States has become a net importer of virtually all of its aluminum metal, whether as bauxite, alumina, scrap or primary imports.

Secondary recovery has an additional and critical benefit, however, in that two major costs are eliminated from metal production:

$$
\begin{aligned}
& \text { * power; } \\
& \text { * alumina. }
\end{aligned}
$$

Power is not only a major expense in the manufacture of primary metal, it is a basic constraint due to lack of long term assured supplies. 
Alumina is becoming increasingly costly because of the effect of rising alkali, energy and bauxite charges.

Collection costs, however, show a trend toward leveling off as the informal ad hoc programs appear to be developing into a standardized system with predictable economics.

While scrap can prices vary from region to region, they appear to be in the range of about $50 \%$ of the market price of primary aluminum. This would be consistent with $\$ 180-\$ 200 / T o n$ alumina, and $8 \mathrm{mil}$ power, but no labor, freight or overhead charges.

To the price paid to scrap collectors would have to be added freight, secondary smelter operating costs and overhead. One of the significant advantages secondary metal has is that the metal supply, in effect, is generated at the market rather than at a power or raw material source which is far removed.

In addition to secondary metal as an indirect competitor to alumina, the metal itself is subject to a wide range of potential substitutes in the market place:

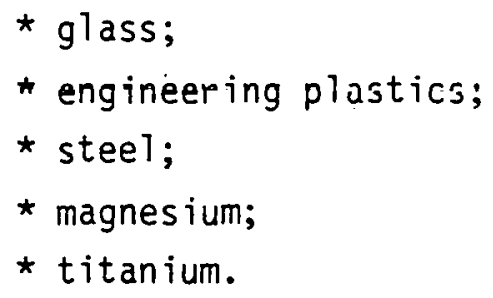

The latter two materials are primarily substitutes in the aircraft industry where high strength to weight rates are critical. Magnesium, in addition, appears to be gaining acceptance because the price of aluminum is rising faster than that of magnesium. ${ }^{25)}$ In addition, new technologies appear to have significant energy savings over those of the past. The comparative energy demand for primary metal production of alumium and magnesium are:

\section{$\underline{B T U / 1 b^{*}}$}

\begin{tabular}{|c|c|c|}
\hline & Aluminum & Magnes ium \\
\hline Current & 80,000 & 140,000 \\
\hline Most Efficient Projected & 45,000 & 75,000 \\
\hline *assumes $10,000 \mathrm{BTU} / \mathrm{Kwh}$ & Source: & $\begin{array}{l}\text { E. G. Higgins, Federal; } \\
\text { Chemical Engineering, June 16, } 1980\end{array}$ \\
\hline
\end{tabular}


It is unlikely, however, that any significant aluminum market would be lost to magnesium.as the projected capacity in 1985 for the world will be only 350,000 metric tons, less than $5 \%$ of aluminum capacity for the world. 26)

Interproduct competition between glass, steel, aluminum and plastics will be discussed later in this section under primary aluminum markets.

New Uses for Alumina

One of the potentially major new uses for alumina may result from development of a FRM (Fiber Reinforced Metal) based upon imbedding Alpha Aluminum 0xide in a metal matrix such as magnesium or aluminum. The potential exists for such composites because of their high stiffness and strength to weight ratios to displace both steel and FRP (Fiber Reinforced Plastics) from auto body components. ${ }^{27)}$

If so, by 1990 alumina fiber could be a substantial new market for alumina independent of primary metal markets. It is not feasible to project the market for this potential end use of alumina due to its conjectural status, but it appears to have major capability.

Primary Nluminum Markets

The demand for aluminum metal, less secondary supplies and imports, establishes domestic alumina requirements. Aluminum metal has six major end use markets:

* construction;

* containers;

* transportation;

* electrical equipment and appliances;

* machinery;

* export.

Demand patterns varied somewhat between 1970 and 1977, the last year for which data were available. The history of domestic consumption patterns from 1969 to 1977 is shown on the following page. 
TABLE 3.39

Domestic A.luminum Demand Patterns

Thousands of Short Tons

\begin{tabular}{|c|c|c|c|c|c|}
\hline End Use Markets & $\underline{1969}$ & $\%$ & $\underline{1977}$ & $\%$ & $\begin{array}{l}\text { \% Annual } \\
\text { Tonnage } \\
\text { Change } \\
\end{array}$ \\
\hline Construction & 990 & 24 & 1,340 & 25 & 3.9 \\
\hline Transportation & 830 & 20 & 950 & 18 & 1.7 \\
\hline Electrical & 600 & 15 & 620 & 12 & 0.4 \\
\hline Containers & 500 & 12 & 1,148 & 21 & 10.9 \\
\hline Appliances \& Equipment & 440 & 11 & 490 & 9 & 1.3 \\
\hline Machinery & 300 & 7 & 440 & 8 & 4.9 \\
\hline Other & 450 & 11 & 390 & 7 & $(\underline{1.8)}$ \\
\hline Total & 4,110 & 100 & 5,370 & 100 & 3.4 \\
\hline
\end{tabular}

Construction applications are primarily in the form of extrusions used in window frames, panels and other building components, siding for residential gutters and siding and similar uses. These end uses do not tend to produce scrap recovery, but rather net disappearance. The demand is very sensitive to cost and availability of money for construction as well as building energy effirienry.

Its primary attraction for commercial construction is ease of fabrication and low maintenance demands. In addition, aluminum can be anodized in a variety of colors and finishes to match architectural requirements.

Primary residential markets are subject to the same financial constraints as commercial but secondary or retrofit sales seem not to be as strongly affected. In part this is a result of homeowners electing to upgrade homes when unable to sell, as well as greater availability of funds for home improvement vs long term financing.

Transportation markets are quite likely to grow rapidly as auto makers reduce vehicle weights in order to achieve higher mileage averages 
for their product mix. This is also true of heavy duty vehicles such as trucks and buses because of the critical importance of fuel costs over the life of the equipment.

Each pound of weight saved in a passenger automobile saves about 1.1 gallons of fuel over the 100,000 mile auto life. With current usage of 118 pounds of aluminum per car, projected savings per million new cars are about 300 million gallons of gasoline. ${ }^{28)}$

The major competitors will be composites such as FRP, 1ightweight high strength steels and new materials such as fiber reinforced alumina. The primary advantage aluminum will have is the fact that, unlike FRP and similar composites, it is recoverable. The economic constraint is that aluminum recoverability at this time, at least, does not benefit the automobile manufacturer directly. The manufacturers choice is based strictly upon the finished cost per pound of a part regardless of what its composition is.

The primary effect of the fairly high worldwide growth rate of $6 \%$ in aluminum metal demand is that at some point significant new alumina capacity will be required. A shale oil industry source, based upon present processing configuration for mineral recovery may have a significant marketing advantage on a world wide basis, absent institutional impediments to entry such as tariffs or sunk investments which must be operated even though marginal.

The remaining markets are fairly insignificant in terms of contribution to demand growth rates. While electrical markets were fairly sizeable, there are few new applications available for long haul transmission lines, the primary use, and the domestic home wiring market has been essentially eliminated as a growth application because of alleged safety problems when there is not careful installation at junction boxes. This has not been definitely established, but it has cast some doubt over the future potential.

Container usage of aluminum, especially for beer which is usually produced in large facilities and shipped considerable distances, is growing rapidly. 
Soft drink bottlers typically are local, with the product having a lower sales margin as a rule than beer, and the markets are highly competitive. As a result, there is greater emphasis upon package cost coupled with avoidance of recycling expenses due in part to resistance by retailers, as well as unfavorable logistics.

So called "bottle laws" have been instituted in several states as a means to limit littering but have been controversial in their acceptance. They appear to function, but acceptance has been mixed.

There are only two aluminum container. markets of significance:

* beer in individual serving sizes

( 8 0z. to 16 oz);

* soft drinks in individual sizes.

The primary competitive packaging materials are:

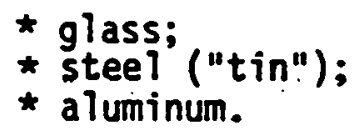

* aluminum.

PET resins are confined to the one and two liter soft drink market because of a combination of resin cost and permeability to oxygen; which adversely affects the taste of beer. ${ }^{29)}$

Steel cans are beginning to lose ground due to a combination of changing technology, adverse economics and a trend to on site production, especially by large brewers. ${ }^{30}$ )

It appears that the future container markets are likely to be largely aluminum and glass, with increasing, but minor, participation by PET resins.

Domestic container market composition is shown in the following table.

\section{TABLE 3.40}

Domestic Container Market Composition 1970-1979

Millions

\begin{tabular}{|c|c|c|c|c|c|c|c|}
\hline Type & End Use & Units & 1974 & $\%$ & 1978 & $\%$ & $\begin{array}{c}\text { Shipments } \\
\text { \% Annuat } \\
\text { Change }\end{array}$ \\
\hline $\begin{array}{l}\text { Steel } \\
\text { Aluminum } \\
\text { Steel } \\
\text { Aluminum } \\
\text { Glass } \\
\text { Total }\end{array}$ & $\begin{array}{l}\text { Soft "Drink } \\
\text { Beer } \\
\text { ". } \\
\text { Soft Drink } \\
\text { Beer }\end{array}$ & $\begin{array}{l}\text { Cans } \\
" \\
" \\
144 \text { Bt7s } \\
\text { ". " }\end{array}$ & $\begin{array}{r}15.5 \\
2.0 \\
14.0 \\
11.9 \\
69.8 \\
52.6 \\
165.8\end{array}$ & $\begin{array}{r}9 \\
1 \\
9 \\
7 \\
42 \\
32 \\
100\end{array}$ & $\begin{array}{r}16.0 \\
10.0 \\
8.3 \\
19.5 \\
61.4 \\
106.5 \\
221.7\end{array}$ & $\begin{array}{r}7 \\
4 \\
4 \\
9 \\
28 \\
48 \\
100\end{array}$ & 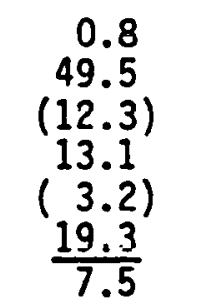 \\
\hline
\end{tabular}


The last market for aluminum is exports. According to the Annual Survey of Manufacturers, 1976, exports of primary aluminum in any form was only $2 \%$ of total shipments, although secondary metal was about $40 \%$ larger than that in absolute amounts (\$279 million dollars for secondary metal vs $\$ 200$ million for primary). In general the U. S. is an importer of aluminum rather than an exporter.

U. S. dependence upon export markets differs substantially from other nations who typically ship higher percentages of production to export markets. Often the production facilities have been sized upon the premise that capacity in excess of domestic needs would serve export sales. This is illustrated in the following tabulation of foreign production by selected producing nations.

TABLE 3.41

$\frac{\text { Reported Disposition of Aluminum Metal Production }}{1978}$

Thousands of Metric Tons

\begin{tabular}{|c|c|c|c|c|c|c|c|c|}
\hline \multirow[b]{2}{*}{ Country } & \multirow[b]{2}{*}{ Region } & \multirow[b]{2}{*}{ Transport } & & \multirow{2}{*}{\multicolumn{2}{|c|}{ Other $\begin{array}{l}\text { Direct } \\
\text { Export }\end{array}$}} & \multirow{2}{*}{ Total } \\
\hline & & & Electrical & $\begin{array}{l}\text { Construction } \\
\& \text { Mechanical }\end{array}$ & Container & & & \\
\hline W Germany & W Europe & 256 & 62 & 250 & 94 & 241 & 358 & 1261 \\
\hline BLEU $^{\star}$ & " & 2 & 3 & 14 & 7 & 12 & 232 & 171 \\
\hline France & $"$ & 183 & 90 & 83 & 50 & 124 & $27 ?$ & $75 ?$ \\
\hline Italy & " & 177 & 31 & 158 & 61 & 132 & 89 & 648 \\
\hline U. $\mathrm{K}$. & $"$ & 112 & 53 & 83 & 49 & 173 & 68 & 538 \\
\hline U. S. & N. Americ & ca 1421 & 638 & 1790 & 1419 & 913 & 346 & 6527 \\
\hline Japan & Asia & 462 & 210 & 777 & 137 & 417 & 142 & 2145 \\
\hline
\end{tabular}

*Belgium, Luxembourg

Source: OECD: The Non-Ferrous Metal Industry

In the case of foreign producers, even the apparent domestic comsumption was indirectly moved into export markets in the form of fabricated products such as automobiles or machinery.

The importance of export markets to primary aluminum production, as well as that of alumina, and indirectly caustic soda, can be. seen on the following page in the summary of Table 3.41 . 
TABLE 3.42

\section{Aluminum Export as a Percentage of Market For Major Selected Producing Nations $\%$ of Production 1978}

Nation

West Germany

BLEU

France

Italy

United Kingdom

United States

Japan

*Electrical, Construction, Con-

\begin{tabular}{|c|c|c|c|}
\hline Direct Exports & Transport & Qther $^{*}$ & $\begin{array}{c}\% \\
\text { Total } \\
\end{array}$ \\
\hline 28.4 & 20.3 & 51.3 & 100.0 \\
\hline 85.3 & 0.7 & 14.0 & 100.0 \\
\hline 29.5 & 24.3 & 46.2 & 100.0 \\
\hline 13.7 & 27.3 & 59.0 & 100.0 \\
\hline 12.66 & 20.8 & 66.6 & 100.0 \\
\hline 5.3 & 21.8 & 72.9 & 100.0 \\
\hline 6.6 & 21.5 & 71.9 & 100.0 \\
\hline
\end{tabular}

\section{Source: Data from OECD, Tabulation, E. G. Higgins Federal}

Transportation end uses of aluminum have historically been closely tied to aircraft manufacturing, but the recent trend toward increasing the aluminum content of automobiles, including engine blocks for air cooled cngines have caused this application to increase in its significance: This is particularly true of nations such as Japan, west Germany and Italy, all of whom have large automobile export markets.

\section{Major Sodium Oxide Commodities}

Background

There are only two basic sodium oxide chemical commodities:

$$
\begin{aligned}
& \text { * Caustic Soda (Sodium Hydroxide); } \\
& \text { * Soda Ash (Soda Carbonate). }
\end{aligned}
$$

Caustic soda is commercially produced as a co-product of chlorine by electrolysis of $\mathrm{NaCl}$ brine (salt) in the ratio of 1.1 pounds of caustic, dry basis, to one pound of chlorine. The combined product yield is referred to as an electrochemical unit (ECU). The chemical reaction is:

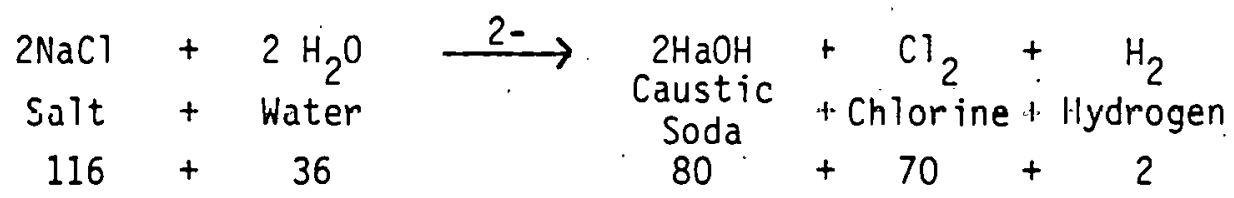


Caustic Soda can also be produced from soda ash by causticizing with lime:

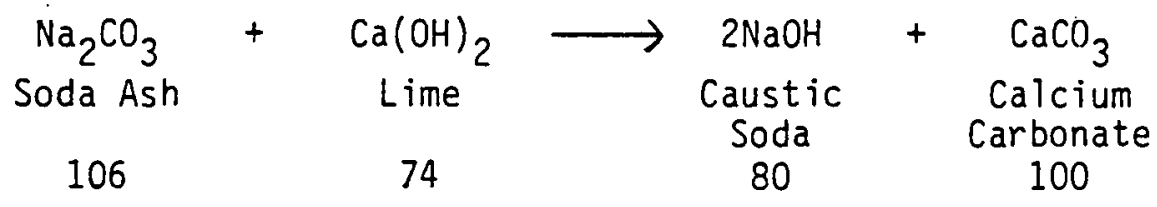

Sodium Sulfate, $\mathrm{Na}_{2} \mathrm{SO}_{4}$, is generally known as salt cake to the paper industry, and if hydrated, as Glauber's Salt. It is a by-product of the recovery of soda ash from California brine lakes (Owens Lake) and certain chemical processes involving sulfuric acid, in particular manufacture of sodium chromates. It is also mined from large high quality deposits hear Monahans, Texas. Its importance is diminishing due to higher recovery efficiencies for chemicals in pulp mill streams.

Other sodium oxide based products of significance are:

* sodium bicarbonate;

* sodium phosphates;

* sodium silicates;

* sodium chromates;

* sodium sulfites, sulfates.

All are derived from either caustic or soda ash, so that their economics are usually a function of the basic oxide source, i.e., soda ash or caustic soda.

Chemical end uses are usually the ones which can use ash or caustic soda interchangabiy, with a few exceptions. The governing consideration is usually what the delivered sodium oxide cost is (see figure 7), and whether the presence of water in the caustic or carbonate ion in the ash would prevent use of one or the other.

The supply of caustic, as discussed previously, is a function of chlorine production rates, hence is involuntary.

Soda ash production is voluntary, with the possible exception of recovery from brines where a number of co-solutes in the brine are recovered in a single process. 
The production of caustic soda and soda ash is discussed in the next section.

Soda Ash Production Capacity and Processes

Soda ash is commercially produced by the following processes:

* Solvay Process;

* recovery from Trona;

* recovery from Lake Brines.

Additionally, it can be produced by carbonation of caustic, as discussed earlier:

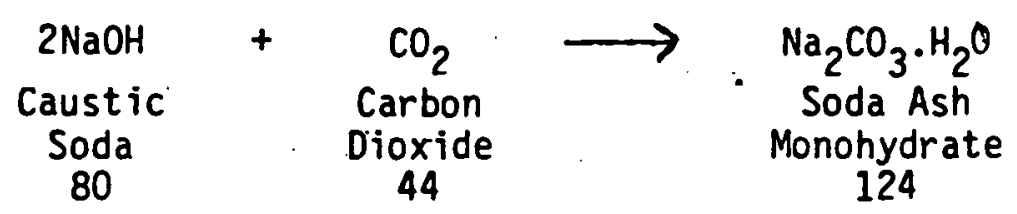

Dow Chemical produced soda ash at Freeport, Texas during a period of great oversupply of caustic in the Sixties, but closed the plant. World production capacity for soda ash is preponderantly Solvay Process, or synthetic, with the balance trona or brine recovery. With the exception of production of crude ash by recovery from Lake Magadi in Kenya (East Africa), all natural ash is produced in the United States. Reported capacity for ash by major process and producing regions is shown in the table below.

TABLE 3.43

Reported World Soda Ash Production Capacity by Process and Selected Region - Thousands of Short Tons

\begin{tabular}{|c|c|c|c|}
\hline Region & Process & Capacity & \\
\hline North America & $\begin{array}{l}\text { Solvay } \\
\text { Trona } \\
\text { Lake Brines }\end{array}$ & $\begin{array}{l}1,900 \\
7,200 \\
1,500 \\
\end{array}$ & $\begin{array}{r}5.2 \\
19.7 \\
4.0 \\
\end{array}$ \\
\hline $\begin{array}{l}\text { Sub-Total } \\
\text { South America } \\
\text { Western Europe } \\
\text { Eastern Europe } \\
\text { Africa } \\
\text { Asia? }^{\text {As }}\end{array}$ & $\begin{array}{l}\text { Solvay } \\
\text { " } \\
\text { " Lake Brines } \\
\text { Solvay }\end{array}$ & $\begin{array}{r}10,600 \\
650 \\
8,670 \\
11,600 \\
370 \\
4,710 \\
\end{array}$ & $\begin{array}{r}28.9 \\
1.8 \\
23.7 \\
31.7 \\
1.0 \\
12.9 \\
\end{array}$ \\
\hline \multicolumn{2}{|c|}{ Total, all Processes } & 36,600 & 100.0 \\
\hline . & $\begin{array}{l}\text { Total Solvay } \\
\text { Total Trona } \\
\text { Total Lake Brine }\end{array}$ & $\begin{array}{r}27,530 \\
7,200 \\
1,870 \\
36,600\end{array}$ & $\begin{array}{r}75.2 \\
19.7 \\
5.1 \\
100.0\end{array}$ \\
\hline
\end{tabular}

1) includes USSR

2) includes Japan, Taiwan, South Korea, India, Pakistan, Peoples Repubiic of China

Source: East/West Trade in Chemicals, OECD 1980; Mineral Commodity Profiles, Bureau of Mines; Bank of Tokyo 
Soda ash production for the years 1970 and 1978 is set forth in the following table, by region.

TABLE 3.44

Reported Soda Ash Production for Major Regions Thousands of Short Tons

\begin{tabular}{|c|c|c|c|}
\hline Region & $\underline{1970}$ & 1978 & $\begin{array}{l}\% \text { Annual } \\
\text { Change }\end{array}$ \\
\hline North Americal) & 7,770 & 9,250 & 2.0 \\
\hline South America & .180 & 370 & 9.4 \\
\hline Western Europe ${ }^{2)}$ & 6,500 & 7,160 & 1.2 \\
\hline Eastern Europe ${ }^{3)}$ & 6,500 & 10,330 & 5.9 \\
\hline Africa & 165 & 210 & 3.1 \\
\hline Asia $\left.{ }^{4}\right)$ & 2,980 & 4,000 & $\underline{3.8}$ \\
\hline Total & 24,095 & 31,320 & 3.4 \\
\hline
\end{tabular}

1) Canada, U. S., Mexico

2) Includes Turkey

3) Includes USSR

4) Includes Peoples Republic of China and Australia

\section{Source: United Nations Statistical Yearbook; Bureau of Mines Mineral Commodity Profiles}

It has been reported that Imperial Chemical Industries moved crude ash recovered from Lake Magadi to the United Kingdom. It is not known what its disposition was.

As discussed previously, much of Eastern Europe's production has been exported primarily to Western Europe, with adverse effect upon pricing. ${ }^{31)}$ Current Western European prices for soda ash are $\$ 124.13$ FOB.

The most notable change in annual production tonnage is that of Eastern Europe, which nearly doubled between 1970 and 1978 . South American production also increased substantially according to the reported data, but is still only a minor source.

The significance of Eastern Europe's increase is that it indicates, if the figures are correct, a substantial growth not only in exports, as discussed previousiy, but a growing internal demand. This is inferred from export figures in comparison to reported production. 
Estimated utilization of capacity for those same regions in 1978 are:

TABLE 3.45

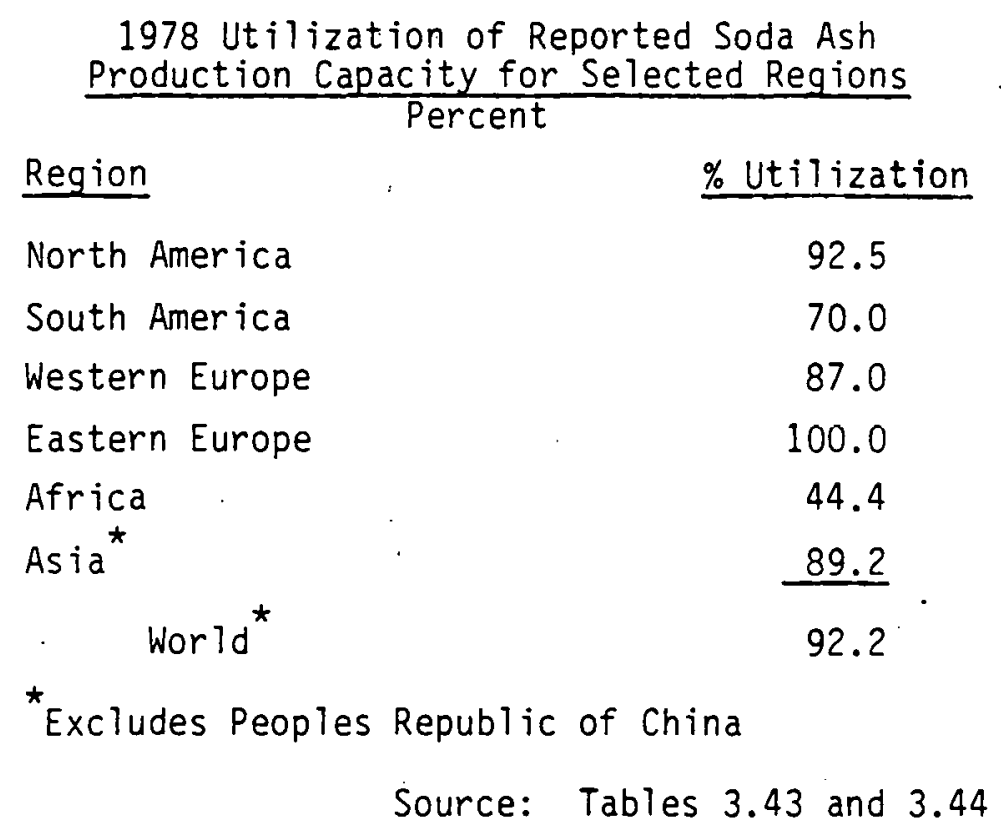

The greatest additions to capacity have been made in the U. S., al though the net change has been relativery small because all U. S. Solvay Process plants have been closed with the exception of Allied's in Syracure, New York. All new U. S. plants have been Trona based.

In terms of net new capacity, Eastern Europe has had the largest percentage increases, as discussed earlier. All European and Asian soda ash plants are Solvay Process. The facilities in Africa are based upon recovery from lake brines.

In terms of oil shale ash production markets, the primary potential is the demand met by Eastern European output. According to OECD, soda ash exports from Eastern Bloc nations to Western Europe are primarily for the purpose of generating hard currency income. Prices, therefore, tend to be only loosely related to cost.

The second potential for U. S. ash production is Western European growth which was largely accommodated by imports and incremental plant increases such as that of ICI. Reported West European additions to capacity between 1977 and 1979 were reported as being approximately 450,000 short tons, not including ICI. 
Reported capacities for selected producing nations are as follows in 1973 and 1979.

TABLE 3.46

Reported Soda Ash Production Capacity

for Selected Producing Nations Ranked by Economy

Thousands of Short Tons

Nation
United States
France
West Germany
Japan
United Kingdom
Other Markets
Sub-Total Market
U.S.S.R.
Peoples Republic of China
Romania
Poland
Bulgaria
Other Managed
Sub-Total Managed
$\quad$ Total

\begin{tabular}{|c|c|c|c|}
\hline $\begin{array}{c}\text { Economy } \\
\text { Type } \\
\end{array}$ & $\underline{1973}$ & $\underline{1979}$ & $\begin{array}{l}\% \text { Annual } \\
\text { Change }\end{array}$ \\
\hline Market & 8,300 & 9,600 & 2.5 \\
\hline$"$ & 1,800 & 2,000 & 1.8 \\
\hline$"$ & 1,750 & 2,000 & 2.3 \\
\hline$"$ & 1,600 & 1,500 & $(1.1)$ \\
\hline$"$ & 1,500 & 1,800 & 3.1 \\
\hline$"$ & 4,780 & 6,590 & $\underline{5.1}$ \\
\hline$"$ & 19,730 & 23,490 & 3.0 \\
\hline Managed & 4,520 & 6,000 & 4.8 \\
\hline$"$ & 1,500 & 1,500 & - \\
\hline$"$ & 1,500 & 1,500 & - \\
\hline$"$ & 850 & 900 & 0.9 \\
\hline$"$ & 350 & 1,700 & 30.5 \\
\hline \multirow[t]{3}{*}{$"$} & 1,380 & 1,510 & 1.4 \\
\hline & 10,100 & 13,110 & 4.4 \\
\hline & 29,830 & 36,600 & 3.5 \\
\hline
\end{tabular}

Source: Minerals Commodity Profiles, Bureau of Mines

Most of Eastern Europe's plants have been built within the past six years, whereas Western Europe and Japan's plants largely predate World War I as part of the original Solvay Process Syndicate. ${ }^{32)}$ Although the plants differ greatly in age, their process economics are essentially the same. Since Eastern bloc countries do not treat capital investment in the same manner as private sector firms do in market economies, there are probably no substantive differences in process economics between market sector amortized facilities and new managed economy plants. 
Solvay Process economics are highly sensitive to ammonia losses as. well as fuel and labor costs. The Solvay Process has many phase changes, with two of the most critical involving ammonia. Phase changes are energy intensive, and the combination of steam, corrosive gases and chlorides causes equipment to deteriorate rapidly, so that maintenance requirements are very high.

The net reaction is very simple:

$$
\begin{array}{ccccc}
2 \mathrm{NaCl} & +\mathrm{CaCO}_{3} \\
\mathrm{Salt} & \text { Limestone } & \text { ima } & \mathrm{Na}_{3} & +\mathrm{CaCl}_{2} \\
116 & 100 & \text { Soda Ash } & \text { Calcium Chloride } \\
106 & 110
\end{array}
$$

The conversion of salt to soda ash, however, requires intervening steps employing ammonium bicarbonate and lime. The ultimate reaction product preceding soda ash is sodium bicarbonate, which must be decomposed to soda ash by heating to $180^{\circ} \mathrm{F}$.

The carbon dioxide required to form ammonium bicarbonate from ammonium hydroxide is produced by calcining limestone to form calcium oxide and lime. Both the calcination and decomposition steps are energy intensive, and $\mathrm{CO}_{2}$ compression also has high utility demands to run the prime movers.

Corrosion and plugging of equipment due to precipitates formed from magnesium and calcium compounds in the brine solution are major operational and maintenance problems, and account for the high labor costs.

The two major location parameters for Solvay process plants in the U. S. were raw materials and markets. The raw materials, salt, limestone and coal or other fuel, were generally available throughout the U. S., so the next governing variable was market location.

Since glass was, and remains, the primary end use of soda ash, much of the U.S. soda ash capacity was in the Midwest, especially Ohio and Michigan. The remaining plants were in the Southeast and Southwest. Freight equalization against producers located closer to consumers was an important element in plant net back economics, and eventually played a determining role in closing Solvay plants in the U.S. 
TABLE 3.47

$\frac{\text { Estimated Solvay Process Direct Manufacturing Costs }}{\text { \$/Ton }}$

\begin{tabular}{|c|c|c|c|c|c|}
\hline Cost Center & Units & Units/Year & Units/Ton & $\$ /$ Unit & $\$ /$ Ton \\
\hline Labor & Man Hour & 135,000 & 0.383 & $10 / \mathrm{hr}$ & 3.83 \\
\hline Fuel & MCF & $7.17 \times 10^{6}$ & 19.92 & 2.50/MMBTU & 49.80 \\
\hline Power & Kwh & $22.8 \times 10^{6}$ & 63.33 & $0.034 /$ Kwh & 2.15 \\
\hline Ammonia & Tons & 1,100 & 0.0032 & 150/Ton & 0.48 \\
\hline Brine & Tons & $560 \times 10^{3}$ & 1.60 & 3.80/Ton & 6.08 \\
\hline Limestone & Tons & $444.5 \times 10^{3}$ & 1.27 & $5.00 /$ Ton & 6.35 \\
\hline Maintenance & Dollars & $2,900 \times 10^{3^{*}}$ & 8.30 & - & 6.30 \\
\hline Other & Dollars & $143 \times 10^{3^{*}}$ & 0.41 & - & 0.41 \\
\hline Tot & & & & & 77.40 \\
\hline
\end{tabular}

Basis: 350,000 Short Tons/Year Light Soda Ash 135,000 Short Tons/Year Dense Soda Ash

*Estimate basis: 1965 dollars using GNP Deflator

Source: Chemical Process Industries, Shreve; Industry

The cost estimates are based upon what is believed to be the minimum for which a Solvay Process plant could make soda ash in terms of direct out-of-pocket expense per short ton.

Current prices for light soda ash $\left(58 \% \mathrm{Na}_{2} \mathrm{O}\right)$ in selected nations are:

\begin{tabular}{|c|c|c|c|}
\hline Nation & $\begin{array}{c}\text { Local } \\
\text { Currency }\end{array}$ & Unit & \$/Ton \\
\hline United States & $\$ 86$ & Short Tons & 86 \\
\hline W. Europe ${ }^{1)}$ & \pm 57 & Metric Ton & 1 \\
\hline Japan 2) & $\pm 51,000$ & $"$ & 222.50 \\
\hline
\end{tabular}

1) British Pound at $\$ 2.40$

2) Yen at $208 / \$$

Source: Process Economics International, Vol 1 No. 4, Summer 1980

All prices are FOB works, so that freight must be added. 
In terms of sodium oxide equivalent, each of the markets have the following oxide price for soda ash, basis $100 \% \mathrm{Na}_{2} \mathrm{O}$.

\begin{tabular}{lc} 
Market & \$/Ton $\mathrm{Na}_{2} \mathrm{O}$ \\
\cline { 2 - 2 } United States & 148.17 \\
Western Europe & 214.01 \\
Japan & 383.62
\end{tabular}

Caustic soda prices, on an equivalent oxide basis for the same area are:

$\begin{array}{llll}\text { Market } & \text { Price/Ton } & & \text { S/Ton } \mathrm{Na}_{2} \mathrm{O} \\ \text { United States } & 160-200 & & 197-263 \\ \text { Western Europe } & 261 & & 344 \\ \text { Japan } & 283 & 373\end{array}$

Source: Process Economics International, Vol $1, \# 4$

The direct costs do not reflect additional charges for taxes, insurance, supervision, administration, return on investment and profit.

The manufacturing costs cited are believed to be very conservative, especially with respect to labor which now runs approximately $\$ 15$ per hour, including burden, on the U. S. Gulf coast.

Fuel costs are the largest single variable and are likely to be far higher in both Europe and Japan. For this reason, the Solvay Process plants were closed in the U.S. because they could not compete with Trona based production, even with a Trona based freight disadvantage from Green River, Wyoming. In addition, it was becoming increasingly costly and difficult to dispose of the by-product calcium chloride which was produced in the ratio of one ton per ton of ash.

European and Asian Solvay plants are essentially in the same posture as U. S. facilities were ten years ago, with the exception of the environmental pressures which are less forbidding. Certain plants not in a position to dispose of brine to the sea, however, are experiencing some problems, but not enough to force a closing at this time.

U. S. Trona based production capacity is being increased rapidly, 
and with potential to increase it still further with only incremental expenditures. Vigorous efforts are being made by several potential producers to commercially develop solution mining as a means to reduce mining costs and manpower needs. The latter has the potential for being the limiting case for future production unless solution mining becomes a viable system.

It is believed that indigenous Trona based capacity will be adequate to meet foreseeable domestic needs, plus meet reasonable export requirements. Much of the domestic chemical market, furthermore, is captive so that an oil shale producer would not have access to that proportion of demand. Soda ash demand will be discussed in the following section.

Trona based ash economics differ significantly from synthetic ash largely because the costs include mining as well as manufacturing variables. In addition, a $14 \%$ depletion allowance is granted producers of ash from natural sources.

Mining is capital intensive, with substantial delay between commencement of mine development and first production. In addition, mining is labor intensive, even with large automatic miners. Even with the demand for mining personnel, however, labor requirements for Trona production are less than half that of synthetic plants. ${ }^{33)}$

The process is very straightforward, and analgous to oil shale production. The steps are:

1. Mining of Trona -1.8 tons of Trona are required per per ton of ash.

2. Calcination of crushed ore.

3. Dissolving of calcined Trona to remove insolubles.

4. Concentration and precipitation of crystalline material.

5. Calcination to remove water of crystallization.

6. Screening.

The utility and energy requirements for soda ash production are significantly lower than for Solvay Process ash, being about $50 \%$ of the latter according to a Bureau of Mines Survey. The limiting case for Trona is boiler capacity; virtually all new Wyoming facilities are 
now coal fired so that energy costs, unlike Solvay Process plants, are modest and are unlikely to increase in cost as rapidly as petroleum.

Recovery of minerals from lake brines is much more complex, and in fact the development of a commercial process to do so won a major engineering honors award.

One of the major domestic expansions reportedly is having difficulty attaining full operating rates, which has resulted in some temporary shortages of ash in Eastern markets which the plant was to serve by ship.

End Uses of Soda Ash.

The major domestic end uses of soda ash are as follows:

* Glass

Flat

Container

Fiber

* Chemicals

Sodium Bicarbonate

Sodium Phosphates

Sodium Silicates

Sodium Chromates

- Pulp and Paper

Chemical Make up to Kraft Mills

* Water Treatment

* Textile Processing

* Soap

* Metallurgy

Aluminum

Chromium

Uranium

Glass

Glass represents over $50 \%$ of all end uses of soda ash. There are four general types of sodium glasses: 
* Container

* flat

* Fiber

* Art and Decorative.

Glass is the result of melting high silica sand $\left(\mathrm{SiO}_{2}\right)$, soda ash $\left(\mathrm{Na}_{2} \mathrm{CO}_{3}\right)$, salt cake $\left(\mathrm{Na}_{2} \mathrm{SO}_{4}\right)$, limestone and other materials in a furnace at about $2800^{\circ} \mathrm{F}$. Typical compositions of representative glasses are as follows:

TABLE 3.48

$\frac{\text { Typical Glass Composition }}{\text { Weight } \%}$

Type Glass

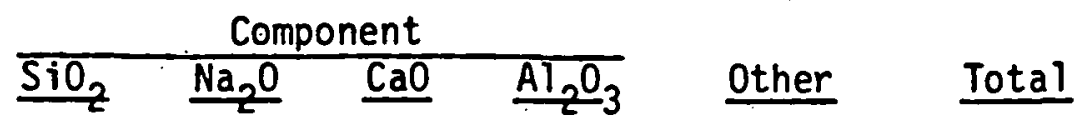

Flat

$\begin{array}{lrrrrrr}\text { Plate } & 72.7 & 13.2 & 12.9 & 0.5 & 0.7 & 100.0 \\ \text { Sheet } & 72.1 & 16.2 & 9.1 & 0.8 & 1.8 & 100.0\end{array}$

Container

Owens Illinois

Medina Flint

Fiber

$\begin{array}{rrr}74.5 & 15.0 & 5.5 \\ 40.6 & 1.5 & -\end{array}$

$\begin{array}{lll}65.0 & 12.0 & 9.0\end{array}$
0.8

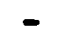

4.0

Source:
Rogers Manual of Industrial Chemistry; Considine: Manufacture of Glass

It should be noted that a pound of $\mathrm{Na}_{2} \mathrm{O}$ requires 1.72 pounds of soda ash, the form in which $\mathrm{Na}_{2} \mathrm{O}$ is added to the melt.

Glass production is energy intensive, and requires approximately 12 million BTUs per ton to melt the reactants. Glass production is the first step in an integrated manufacturing process from glass to finished products. The conversion steps are primarily mechanical, either drawing the glass out in a sheet to form flat glass, or extruding "gobs" which are dropped into molds and formed into containers or other shapes. Glass may also be pressed into forms or spun into glass fiber.

Glass production (see figure 5) is primarily dependent upon natural gas for a fuel because of its clean burning characteristics and 
hitherto low cost. Glass plant location is primarily market and raw material determined, with the proximity of a suitable glass sand, or silica, being one of the most important.

Market location is critical for container plants because of the low weight to volume ratios of glass to containers, so that freight is an important consideration. This is particularly so because glass is not normally recycled, and except as cullet or broken glass, is not returned to the glass plant.

Glass had the following production history by end use.

TABLE 3.49

Domestic Shipments of Glass by End Use

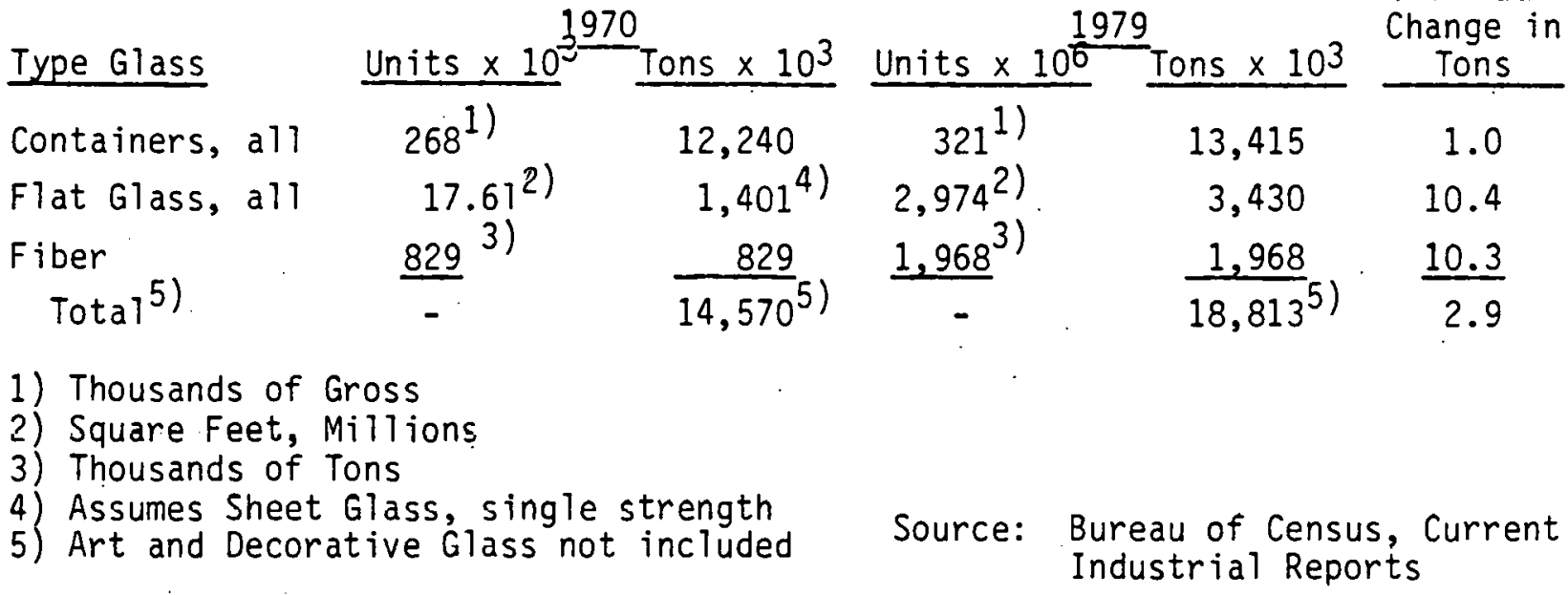

Assuming the glass types to have an average $\mathrm{Na}_{2} \mathrm{O}$ content as specified, each would have consumed the following amounts of soda ash in 1979.

TABLE 3.49

Imputed Soda Ash Consumption in Glass by Type, 1979

\begin{tabular}{|c|c|c|c|}
\hline Glass Product & $\% \mathrm{Na}_{2} \mathrm{O}$ Content & $\begin{array}{l}\text { Production } \\
\text { Thous Tons } \\
\end{array}$ & $\begin{array}{c}\text { Soda Ash Equivalent } \\
\text { Thous Tons } \\
\end{array}$ \\
\hline $\begin{array}{l}\text { Containers } \\
\text { Flat Glass } \\
\text { Fiber }\end{array}$ & $\begin{array}{l}15.0 \\
15.0 \\
12.0\end{array}$ & $\begin{array}{r}13,415 \\
3,430 \\
1,970 \\
\end{array}$ & $\begin{array}{r}3,470 \\
890 \\
410 \\
\end{array}$ \\
\hline Total & & 18,815 & 4,770 \\
\hline
\end{tabular}

Source: E. G. Higgins, Federal 
Thus, of the total soda ash production in the United States, $4,800,000$ tons went to glass shipments. Production was approximately $4 \%$ higher because of captive use and various other differences, including stocks. Shipments figures were used because they more accurately depict the ultimate disappearance of soda ash in the year selected.

The tonnage of glass shipped, by category of .end use, had the following pattern in 1970 and 1979.

TABLE 3.50

Domestic Glass Shipments by Type for Selected Years Weight \%

\begin{tabular}{lrr} 
Type Glass & $\underline{1970}$ & $\underline{1979}$ \\
\hline Containers & 84.8 & 71.3 \\
Flat Glass & 9.6 & 18.2 \\
Fiber & $\frac{5.6}{100.0}$ & $\frac{10.5}{100.0}$ \\
$\quad$ Total & 100.0 &
\end{tabular}

Source: E. G. Higgins Federal

Flat glass shipments increased significantly largely as a result of new Federal safety regulations requiring safety glass to be used in all replacement uses for certain construction applications, especially commercial installations. In addition, tax credits made available under the energy act for double glazing increased demand. Safety regulations increased gláss thickness while double glazing increased total demand.

Fiber glass experienced a similar increase due to energy tax credits, and growing use of FRP in automobiles and other uses.

Containers constitute the largest single glass market, and in- .

directly, soda ash. The glass container market, however, has undergone considerable change in its product mix, particularly in food, health, chemical and toiletry uses for both widemouth and narrowneck categorizs. For the most part, these changes were due to displacement by plastics such as HOPE (High Density Polyethylene), PPE (Polypropylene) and PVC. (Polyvinyl Chloride). 
The glass container market is segmented by product as follows:

TABLE 3.51

Domestic Glass Container Shipments

by Product Type and End Use

$$
\text { Millions of Units }
$$

\begin{tabular}{|c|c|c|c|c|c|c|}
\hline $\begin{array}{c}\text { Type } \\
\text { Container } \\
\end{array}$ & End Use & $\underline{1970}$ & $\%$ & $\underline{1979}$ & $\%$ & $\begin{array}{l}\text { \% Annual } \\
\text { Change in } \\
\text { Shipments }\end{array}$ \\
\hline \multirow[t]{7}{*}{ Narrowneck } & Sub-Total & 28,722 & 75.0 & 35,556 & 78.0 & 2.4 \\
\hline & $\begin{array}{l}\text { Food, Health, Chemi- } \\
\text { cal and Toiletry }\end{array}$ & 8,041 & 21.0 & 7,478 & 16.5 & $(0.8)$ \\
\hline & Beverage, Returnable & 1,716 & 4.5 & 869 & 1.9 & $(7.3)$ \\
\hline & $\begin{array}{l}\text { Beverage, Non-Return- } \\
\text { able }\end{array}$ & 8,343 & 21.8 & 7,051 & 15.5 & $(1.9)$ \\
\hline & Beer, Returnable & 338 & 0.9 & 383 & 0.8 & 1.4 \\
\hline & Beer, Non-Returnable & 7,240 & 18.9 & 16,015 & 35.1 & 9.2 \\
\hline & Liquor and wine & 3,044 & 7.9 & 3,760 & 8.2 & 2.4 \\
\hline \multirow[t]{6}{*}{ Widemouth } & Sub-Total & 9,586 & 25.0 & 10,025 & 22.0 & 0.5 \\
\hline & $\begin{array}{l}\text { Fruit, Jelly and } \\
\text { Packers }\end{array}$ & 8,443 & 22.0 & 9,578 & 21.0 & 1.4 \\
\hline & Health and Chemical & 798 & 2.1 & 277 & 0.6 & $(11.1)$ \\
\hline & Toiletries and Dairy & 345 & 0.9 & 170 & 0.4 & $(7.6)$ \\
\hline & $\begin{array}{l}\text { Grand Total, A11 } \\
\text { Containers }\end{array}$ & 38,308 & 100.0 & 45,581 & 100.0 & 1.9 \\
\hline & & & Source & $\begin{array}{l}\text { Cur } \\
\text { Bur }\end{array}$ & $\begin{array}{l}\text { Inde } \\
\text { of } \mathrm{Ce}\end{array}$ & ial $R$ \\
\hline
\end{tabular}

The weight of glass required for these market sectors differed in some categories of end use, a point of importance to soda ash consumption. End use changes reflect the consequences of interproduct competition upon glass tonnage, and thus indirectly soda ash demand.

Density differentials affect not only the weight of materials used for a specific category, but the economics as well. In addition, fabrication costs are influential components in the point of use economics for specific container materials. Product economics will be discussed in Section IV. 
For the same periods and product categories, the glass consumption by weights was reported as follows:

\title{
TABLE 3.52
}

Weight of Domestic Glass Container Shipments by Product Type and End Use

$$
\text { Thousands of Tons }
$$

Type

Container

Narrowneck
End Use

Sub-Total

Food, Health, Chemical and Toiletry

Beverage, Returnable

Beverage, Non-

Returnable

Beer, Returnable

Beer, Non-Returnable

Liquor and Wine

Widemouth
Sub-Total

Food, Jelly, Dairy

Medicine and Health

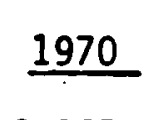$$
\text { (n) }
$$

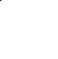


medicine and health glass container markets shifted toward PPE and other resins.

The decline in returnable beverage containers appears to be a result of a preference by consumers for non-returnable bottles. The returnable beverage containers were largely "family size" one or two liter bottles. Between 1978 and 1979 this market declined from about two billion units to 1.2 billion, according to census data, which accounts for much of the drop in returnable beverage sales.

In addition to the reduction in market size, glass containers were subject to considerable displacement by PET resins in the returnable beverage one or two liter catagory. According to reported data, sales of PET bottles and glass were as follows in 1979.

TABLE 3.53

1979 One and Two Liter Bottle Sales of PET Resin and Glass

Million

$\begin{array}{lrrr} & \frac{\text { PET }}{150} & \text { Glass } & \text { Total } \\ \text { One Liter } & 1,000 & 1,150 \\ \text { Two Liter } & \frac{1,500}{1,650} & \frac{330}{1,330} & \frac{1,850}{2,980}\end{array}$

Source: Current Industrial Reports, Bureau of Census; AiChe Fuels and Petrochemicals, Div. 88th Annual Meeting "PET in the Container Market", R. Gutekunst

Projection for PET sales in these two categories are for a doubling by 1984, assuming no unusual constraints in availability of the para-xylene used as a feedstock for the terephthalic acid.

PET is not suitable for beer because of its permeability to oxygen, as discussed previously. It is unlikely PET will be extended into smaller beverage sizes because of several factors, viz, the disproportionate cost of container to product, manufacturing limits and raw material constraints. 
Had AN (Acrylonitrile) resin bottles been permitted into the beverage or beer markets, it is likely that a sharp drop in glass container sales would have resulted. By application of the Delaney Clause forbidding use of any product which might cause cancer, AN resins were banned.

Application for PVC to be used in liquor containers has been made, which if approved could have substantial impact in the future upon soda ash, not only by reducing glass sales but also by increasing chlorine demand. The latter would produce more co-product caustic to compete with ash.

It would appear that much of the displacement of glass by plastics has already occurred in the United States, and while it will continue, substitution will be at a slower rate.

As can be seen in Table 3.40, page III-46, glass has actually increased its share of beer container markets by about $50 \%$ between the years 1974 and 1978, while aluminum rose only 29\% in the same period.

It would appear that glass containers will continue to enjoy a significant advantage in this growing market. The primary container markets for glass are food and beverage applications which are related to population growth and likely to grow at a one to two percent per year rate as a base, or about equal to real GNP.

The increasing trend toward non-breakable or flexible containers in medicinal, toiletries and health applications may result in further declines in glass sales to these markets. Since they are not major end uses, the food and beer markets should be able to make up the loss.

Flat glass shipments are divided into two general categories:

* sheet or window glass;

* plate.

Plate glass is further segmented into construction and automotive applications. The latter market has been heavily influenced by the drop in domestic new auto sales on a unit basis, but the lower density ( $1 / 3$ that of steel) of glass has resulted in greater use per unit as manufacturers attempt to reduce auto weight. 
With 154 million registered vehicles in the United States, replacement sales are an increasing market factor, especially in urban areas.

Flat glass shipments for 1970 and 1979 by category are reported in the table following:

TABLE 3.55

\begin{tabular}{|c|c|c|c|c|c|}
\hline Category & MMft $2^{2}$ & Tons $\times 10^{3}$ & MMft 2 & Tons & $\begin{array}{l}\text { \% Annual } \\
\text { Change in } \\
\text { Tonnage }\end{array}$ \\
\hline Window ${ }^{1)}$ & 1,070 & $660^{3)}$ & N.A. & N.A. & - \\
\hline Prate ${ }^{2)}$ & 690 & $740^{4)}$ & N.A. & N.A. & - \\
\hline Total & 1,760 & 1,400 & 2,975 & 3,430 & 16.3 \\
\hline
\end{tabular}

1) Sheet Glass reported in Thousands of boxes of 50 Square Feet

2) Plate, Flat, Rolled and Wire Glass, Thousands of Square Feet

3) Assumed single strength of 1,230 1b/Thou Sq Ft

4) Double strength assumed

Source: Bureau of Census, Current Industrial Reports

Market trends for flat glass in construction are toward thicker glass because of federal regulations requiring tempered glass in new installations and replacement glass.

Automotive glass has tended toward thinner and tougher qlass in order to reduce weight.

Public transportation window materials are tending toward use of polycarbonate or acrylic resins because of resistance to breakage and vandalism. Public transportation, however, is a relatively small market in comparison to automobiles and trucks.

Fiborous glass markets are for two general classes of end use:

* insulation fiber,

* textile fiber.

Both end uses have grown rapldiy, but have many competitors. Insulation markets are served by rock, or mineral wool, urethane, styrene and fireproofed cellulose to name a few.

Textile markets are principally as an engineering material in confunction with polyester resins. 
The production history for fiber glass for the years 1970 and 1979 was reported as folliows:

TABLE 3.56

Domestic Fiber Glass Production

For Selected. Years

Thousands of Short Tons

\begin{tabular}{|c|c|c|c|c|c|}
\hline Type & $\underline{1970}$ & $\%$ & $\underline{1979}$ & $\%$ & $\begin{array}{l}\text { \% Annual Change } \\
\text { in Production } \\
\end{array}$ \\
\hline Textile & 234 & 28.2 & 526 & 26.7 & 9.4 \\
\hline Insulation & $\underline{595}$ & 28.2 & 1,442 & 73.3 & 10.1 \\
\hline Total & 829 & 100.0 & 1,967 & 100.0 & 10.1 \\
\hline
\end{tabular}

Source: Current Industrial Reports, Bureau of Census

Textile fiber glass demand is growing due to increasing utilization in FRP (Fiber Reinforced Plastic) automotive body parts because of its light weight, dimensional stability and ease of fabrication. It is estimated that $61 \%$ of all FRP end uses are accounted for by marine, transportation and construction sectors. ${ }^{34)}$ Insulation markets, after a very sharp rise beginning in 1975, have slowed somewhat but are expected to increase again as energy costs grow.

A final note on soda ash consumption in glass is that some of the sodium oxide can be supplied in the form of usually less expensive sodium sulfate. The proportions that can be utilized, however, are limited.

Chemicals

The largest portion of chemical demand for phosphates is accounted for by only a few products:

* Sodium Bicarbonate;

* Sodium Chromates;

* Sodium Phosphates;

* Sodium Silicates.

Chemical markets for soda ash differ substantially from those of. glass. Not only is the total volume smaller, being only half that of glass, 
but it is also characterized by a significant amount of forward integration by ash producers, particularly in phosphates.

In terms of volume of production, the largest volume product group is phosphates, followed by silicates, bicarbonate of soda and chromates. In addition there are a large number of minor products such as bisulfites and other salts which in aggregate amount to about $10 \%$ of the inorganic sodium oxide markets.

The production history of the major chemical end uses of soda ash for the years 1970 and 1979 were as follows:

TABLE 3.57

Production of Major Sodium Oxide Chemicals for Selected Years 1970-1978

Thousands of Short Tons

$\frac{\text { for Selected Years } 1970-1978}{\text { Thousands of Short Tons }}$

\section{Class}

Phosphates

Chemical

Trisodium

Metaphosphate

Pyrophosphate

Tripolyphosphate

Sodium Silicate

Sodium Bicarbonate

Sodium Chrnmat.e

*Estimated

Bicarbonate $\underline{1970 \quad \underline{1978}}$

53

45

78

1,208

889

143

154

Source: Current Industrial Reports, Bureau of Census
$\%$ Annual

Change

2.1

6.4

$1, n$

Sodium phosphates are divided into two general chemical classifications:

* or tho phosphates;

* glassy phosphates.

The or tho phosphates are the primary reaction products between phosphoric acid and either soda ash or caustic soda.

The glassy phosphates are the result of furnacing varying ratios of two or more ortho phosphates to drive off the molecular water.

The essential difference between sodium phosphates is the Mol (weight) ratios between sodium oxide $\left(\mathrm{Na}_{2} \mathrm{O}\right)$ and phosphorus pentoxide $\left(\mathrm{P}_{2} \mathrm{O}_{5}\right)$. 
The latter is derived from phosphoric acid, while the $\mathrm{Na}_{2} \mathrm{O}$ comes from ash or caustic.

The bulk of sodium phosphates employ soda ash as the $\mathrm{Na}_{2} \mathrm{O}$. source, except trisodium phosphate (TSP) which requires one of the three sodiums to come from caustic soda. ${ }^{35)}$

The largest volume product is sodium tripolyphosphate, produced by dehydrating a mixture of Disodium Phosphate (DSP) and Monosodium Phosphate (MSP) in the ratio of 2.37 to 1.0 parts by weight, using a furnace. The soda ash equivalent for the MSP (anhydrous basis) is 0.45 tons of ash per ton of MSP. The DSP soda ash requirement is 0.75 tons of soda ash per ton of anhydrous DSP, giving a combined soda ash equivalent of approximate$1 y 0.73$ tons of ash per ton of tripolyphosphate. Trisodium phosphate requires 1.29 tons of ash and 0.15 tons of caustic soda per ton of TSP.

Tetrasodium Phosphate (TSPP) is produced by calcining DSP in a furnace. Approximately 1.1 tons of DSP are required per ton of TSPP, which is equivalent to about 0.8 tons of soda ash per ton of TSPP.

In 1970 the total ash requirement to produce sodium phosphate was approximately 1,100,000 tons. In 1978 the requirement. was 750,000 tons. This decline was primarily due to the enforced reduction of phosphate content in household detergents to reduce eutrophication in lakes and streams.

The largest single use of phosphates is as a component in "built" soap or detergent mixes, both industrial and home. The other components are sodium sulfate optical brighteners, surfactants, sodium bicarbonate, soda ash and other minor additives. Approximately $70 \%$ of the detergent is sodium sulfate, with between two and thirty percent TSPP.

The ultimate effect upon soda ash use was less than might be anticipated, however, since soda ash and bicarbonate were added directly to the mixes to replace the phosphates.

\section{Silicates}

Sodium silicates are the product of furnacing soda ash and glass sand $\left(\mathrm{SiO}_{2}\right)$ in molar ratios of one soda ash to 2.0 or $3.2\left(\mathrm{SiO}_{2}\right)$, depending upon type. 
Liquid products may be in either ratio, except that the $1: 3.2$ combination is limited in the concentration it can be shipped in to $40 \%$ solids because of lower solubility, whereas 1.2 material can contain $54 \%$ solids.

Soda ash requirements for 1.2 silicates are approximately 0.6 ton per ton of anhydrous silicate, i.e., as if it were not in solution.

The 1:3.2 ratio silicates require slightly less than 0.42 tons of soda ash per ton of anhydrous silicates.

Metasilicates are in the ratio of 1.1 and orthosilicates $2: 1$ of $\mathrm{Na}_{2} \mathrm{O}: \mathrm{SiO}_{2}$.

1970 consumption of soda ash for silicate production was approximately 600 thousand tons, while 1978 demand was around 525,000 tons.

Sodium silicate production is energy intensive and requires about 10-11 million BTUs/ton of anhydrous silicate, and so can be substantially affected by power costs.

Chromates

The primary chromate salt is sodium dichromate, and is produced by sintering chromite ore with soda ash, crushing and leaching the sinter, then acid washing to convert the chromates to acid (dichromates) chromates. Sodium sulfate is produced as a by-product in the ratio of . 0.75 tons of sulfate per ton of ash consumed.

Each ton of sodium dichromate requires about 0.8 tons of soda ash. Approximately 120,000 tons of soda ash were used in 1970 to produce dichromates. Major markets are leather tanning agents, dye mordants, plating salts and corrosion control agents. Their toxicity is reducing demand for common control in favor of other systems, while plating uses are declining due to a shift by the automobile industry toward other coverings for bumpers and dropping chrome decorative trim.

Sodium Bicarbonate

Sodium bicarbonate is produced by carbonation of soda ash with $\mathrm{CO}_{2}$, followed by crystallization and drying. Production has been increasing rapidly, in part to provide a substitute for the removal of phosphates 
from detergents, and part because of the development of new consumer markets.

Sodium bicarbonate manufacture requires about 0.65 tons of soda ash per ton of bicarbonate, and in 1970 accounted for about 90,000 tons of soda ash, while in 1978 about 250,000 tons were used.

Other Chemical Uses

Other chemical uses of soda ash include neutralization reactions where water' is an undesirable contaminant, as would be the case if caustic were used and where soda ash is used as a feed to a lime-soda caustic plant.

Most neutralization reactions, however, utilize caustic soda if only because vendors of caustic and chlorine prefer to seli an ECU (Electrochemical Unit) to keep a marketing balance. If the plant is captive, then it is easier and cheaper to use cell liquor. In addition, because of the higher equivalent weights required for soda ash per hydrogen ion neutralized, soda ash is usually more expensive to use. The last objection is the foaming which results from evolution of $\mathrm{CO}_{2}$ as the neutralization takes place.

It is not likely that soda ash will make much penetration into chemical neutralization end uses for the above process reasons unless the delivered cost of $\mathrm{Na}_{2} \mathrm{O}$ from caustic rises to a point about \$10/ton higher than that of soda ash for a prolonged period, and if caustic is unavailable. New Chemical Uses

Production of sodium percarbonate has begun in Houston, Texas, but it is believed that the production route is likely to use caustic soda rather than soda ash as a sodium oxide source. Production in any event is not likely to be a significant consumer of sodium oxide chemicals since its market is highly specialized.

Recovery of yellow cake (Uranium oxide $-U_{2} \mathrm{O}_{8}$ ) from uranium ore utilizes either caustic or soda ash to precipitate out the oxide from the acid leach. Recovery processes from phosphate mining and fertilizer operations were being developed, and in operation at some locations. ${ }^{36)}$ The 
sodium oxide source, however, is believed to be caustic soda. Pulp and Paper

Consumption of soda ash in pulp and paper production is relatively low, and primarily for the kraft industry in lieu of salt cake (Sodium Sulfate) makeup.

Approximately 60-100 pounds of salt cake equivalent/ton of Air Dry (AD) pulp is required for make-up to the chemical loop of a kraft mill. The two components of salt cake utilized by the mill are $\mathrm{Na}_{2} \mathrm{O}$ and sulfur (salt cake is $\mathrm{Na}_{2} \mathrm{SO}_{4}$ ). Due to environmental constraints, sulfur recovery efficiencies have been increasing, in order to reduce emissions, while sodium oxide losses have not been as easy to control, in part because of losses in wash water from pulp washing.

As a result it has been necessary for mills to add sodium oxide make-up independently of sulfur, so that some mills have tended to use ash or caustic rather than salt cake, especially where caustic is already used for the bleach plant.

The choice is always economic, and generally favors caustic in the Southeast and South because of freight costs for. trona based ash ( $\$ 42.50 /$ ton to Houston). For a Gulf Coast plant, at $\$ 150 /$ ton of caustic soda, delivered, it would be $\$ 30 /$ ton of sodium oxide cheaper to use caustic soda than soda ash, and only one storage and handling system would be needed.

Pulp production is not likely to be a significant consumer of soda ash because of these competitive products and the wide range of choices kraft mills have in chemical raw materials.

Approximately 1.0 million tons of salt cake or its equivalent. were used in 1979 for make-up to kraft mills, with additional use of sodium thiosulfate in small amounts (less than 50,000 tons) for thermomechanical pulp.

It is possible under some conditions that spent nahcolite from stack gas scrubbing (SGS) using dry sodium technology could find a home in this application, but a great deal would depend upon freight rates and the effect of other contaminants in the scrubber effluent. 
In any event, it is doubtful that the entire salt cake market could be pre-empted because about $1 / 3$ of the supply is by-product material from chromate and other similar processes which generate sodium sulfate as a reject product.

Textile Uses

Soda ash is widely used in textile processing for wools and cottons, but the aggregate use is relatively small and confined primarily to the Southeast.

Soap and Glycerine

Production of soap and natural glycerine requires relatively small amounts of caustic soda in the U.S. in comparison to process users. Solid soaps are the sodium salts of various fatty acids, usually stearic, while liquid soaps are the potassium salts. Each ton of solid soap requires approximately 0.14 tons of caustic soda, while each ton of glycerine demands 1.3 tons of caustic. ${ }^{37)}$

In Europe, however, soap production is a more important market, relatively speaking. In part this is due to a society which has fewer automatic washing machines per capita, softer water and not as great a detergent market as the U. S.

Rayon

Production of rayon fibers, while sharply diminished in the U.S., is still a large industry elsewhere in the world.

The process is an intricate and technologically difficult one in which cellulosic materials are converted into man made (as opposed to synthetic)polymers.

Each pound of rayon requires approximately one pound of caustic soda of a very high quality ("Rayon Grade"), and results in about 0.8 pound of by-product salt cake.

According to the data reported in the United Nations Statistical Yearbook, world production in 1976 of rayon and rayon acetate continuous filament and discontinuous fibers amounted to over 3,200,000 metric tons. Although the acetate process does not use caustic soda, if the division is 
assumed to be 50/50 for each product, over 1.5 million metric tons of caustic soda would have been consumed in the production of rayon. Of that 190,000 tons would have been produced in the United States. While rayon production has been trending downward with the ascent of synthetics, particularly polyester, in many sectors of the world such as the Peoples Republic of China, it is growing in production.

Competitive Products

Depending upon the end use, there are many competitive products to soda ash. In neutralization reactions, both 1 ime and limestone are typically used, especially for FGD (Flue Gas Desulfurization). The latter is also termed SGS or Stack Gas Desulfurization.

In kraft pulp mills, salt cake, sodium sulfide and other similar compounds can be interchangably utilized. Sulfite pulping processes may employ ammonia, magnesium or caustic soda as the anion source.

At present, these potential or actual uses of competitive materials are very small in comparison to glass and chemical applications. Of these two major end uses, glass is particularly immune to invasion by caustic soda. While technically a great deal of work has been done to prove the applicability of caustic in glass making, especially by PPG Industries (Pittsburgh, Pennsylvania), it does not appear economic.

The chemicals market for sodium oxide chemicals, while theoretically able to interchange the use of caustic and soda ash, is as a practical matter unable to do so. In part this is because, as in the case of silicates and chromates, the conversion takes place with the use of a dry alkali source such as soda ash. Bicarbonate of soda manufacture, while chemically possible using caustic soda as a raw material, is not economic nor practical in comparison to soda ash.

Sodium phosphates could possibly use caustic in many of the reactions were it not for the cost of removing the water and the effects upon the resulting crystallization steps.

In summary of the general case, it is unlikely that caustic would invade many primary soda ash markets. The reasons may be no more than physical barriers to entry, such as the process requiring a dry 
product or a carbonate, or they may be economic.

Soda ash, however, can penetrate caustic soda markets either directly as a solution or indirectly by causticization. The latter case would simply be a reversal of the trend established in the $50^{\prime} \mathrm{s}$ and $60^{\prime} \mathrm{s}$ when lime-soda caustic plants used to balance shortfalls between co-product caustic supplies and demand were closed because of the huge oversupplies of caustic soda.

The production of $1 \mathrm{ime} / \mathrm{soda}$ caustic requires that there be a source of calcium hydroxide $\left(\mathrm{Ca}(\mathrm{OH})_{2}\right)$ to causticize the soda ash:

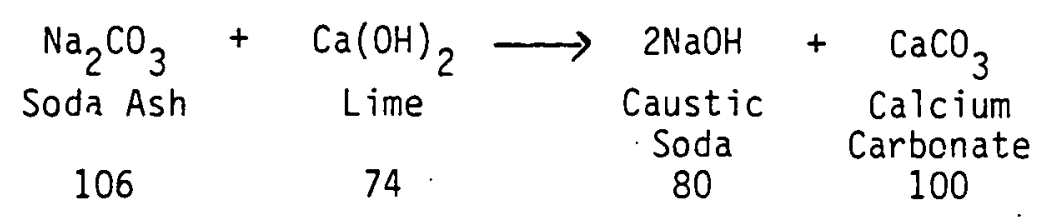

The sludge is normally cycled back through a kiln to convert the carbonate to the oxide, thence to the hydroxide:

1)

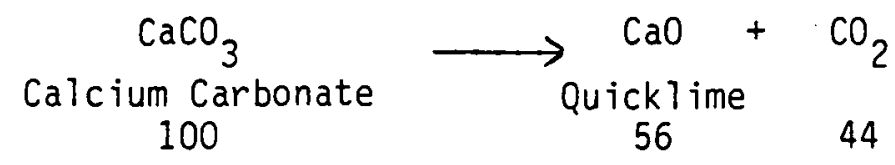

2)

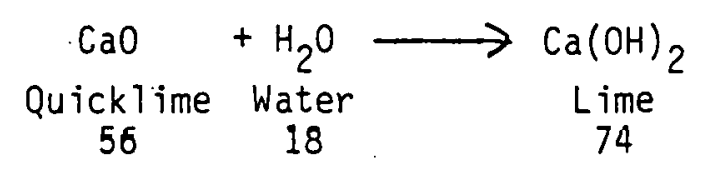

The economics of such an operation are essentially those of fuel requirements to dry the calcium carbonate sludge and decompose it to $\mathrm{CO}_{2}$ and lime, plus the capital and manpower needs for the kiln and slaking operations.

Energy demands can range from as 1 ittle as $4.7 \mathrm{MM} \mathrm{BTU/ton} \mathrm{of} \mathrm{dry}$ 1 imestone to as much as 7.16 MM BTUs. ${ }^{38)}$ Water removal would be an additional thermal load. Kraft mills report 17-21 MMBTUs/ton of lime sludge.

Assuming the average cost energy case, 7 MM BTUs and $\$ 2.50$ per MM BTU fuel price, the expense for 1 imestone (calcium carbonate) decarbonization alone would be $\$ 17 /$ ton, plus drying and other operating and capital charges. If, using a rough rule of thumb, the energy costs were doubled to arrive at an approximate lime cost per ton, causticization chemical 
expense would be in the range of $\$ 30-\$ 35 /$ ton of caustic. Obviously if efficiencies are greater or energy costs lower, this figure could be reduced.

If $\$ 30 /$ ton of caustic were the causticization charge, then the differential between ash and caustic $\mathrm{Na}_{2} \mathrm{O}$ values would have to be about $\$ 40 /$ ton of $\mathrm{Na}_{2} \mathrm{O}$ to make it pay. This can be equated from Figure 7 in the Appendix for any set of values for caustic soda, soda ash, nahcolite or salt cake.

Alumina production, as discussed previously, can utilize either ash or caustic soda and represents a substantial sodium oxide market. It is likely that this particular end use would be the most likely point of interchange between caustic soda and soda ash in the United States at least, and possibly in other countries as well.

A major question mark which has not been addressed is the role of quality in many end uses, especially glass. While some tests have been made on using soda ash or equivalents as semi-refined or crude trona, very few results have been published. It is believed that some semirefined material is moving from Africa into markets in developing countries, but this has not been confirmed by published accounts.

This, however, is a major imponderable to interchange economics because of the implications to direct causticization of trona or nahcolite as well as finished ash. If some markets were to be able to utilize either semi-finished ash or nahcolite, it would have a substantial bearing on ash economics for oil shale based material as well as trona. Needless to say, it would heavily impact Solvay ash.

The primary chemical uses of caustic soda are for the following applications:

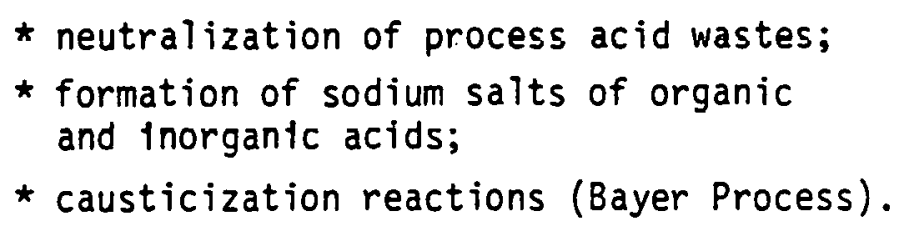

Virtually all chlorination reactions require neutralization of some stream, usually dilute or contaminated, which is not recoverable. 
Industry sources estimate as much as $20 \%$ of all caustic production is utilized solely for neutralization of chlorination reaction products where the $\mathrm{HCl}$ is not economically recoverable. Examples include epichlorihydrin and dichlorobutene processes where the unreacted or reject chlorine ion is scrubbed by caustic and converted to $\mathrm{NaCl}$ (salt) for disposal.

Other neutralization reactions include sulfonation reaction reject streams, saponification of fats and oils for soap production and similar processes.

Water treatment uses of caustic are principally for small, high quality applications such as boiler feed water ion exchange regeneration or $\mathrm{pH}$ adjustment. Treatment of larger streams is almost always by lime softening or salt regenerated systems.

End uses of caustic soda tend to be far more diffuse than soda ash, and many of the uses such as neutralization of waste streams a matter of economics and environmental regulations. Lime is the most economical process neutralization agent as long as it is possible to dispose of the spent $\mathrm{CaCl}_{2}$ (calcium chloride). In the chlorhydrin process for propylene oxide production, lime neutralization is employed. In some other processes, the calcium ion cannot be risked as a possible process contaminant and so caustic soda is used to neutralize any excess or unreacted acid.

The primary use of caustic soda in the pulp and paper industry is in conjunction with chlorine in the bleaching step for mills which bleach. Approximately 1.25 pounds of caustic is used per pound of chlorine, which converts insoluble lign in binder into soluble products which can be caustic extracted. ${ }^{39)}$

A bleach plant will consume approximately $2.5 \%$ of the pulp production by weight as chlorine, depending upon the bleach sequence. The long term outlook is for substantial declines in chlorine bleaching because of environmental regulations covering discharge of chlorinated hydrocarbons.

Assuming a $2 \%$ chlorine demand for pulp bleaching, approximately 400,000 tons of chlorine were used in this application in 1979, and 500-600,000 tons of caustic soda. 
Caustic Soda Supply

It was assumed in this report that involuntary supplies of competitive products would move to market preferentially, whether as exports or direct consumption. In the case of materials competitive to soda ash, caustic soda is the product which is assumed to be the preferential sodium oxide source at equal $\mathrm{Na}_{2} \mathrm{O}$ costs on a delivered basis.

In the event caustic supplies are inadequate to demand, it is assumed soda ash would be utilized where direct substitution is possible with little or no inconvenience, as in kraft pulp mills, and certain alumina operations.

It is assumed that if there are long term deficiencies in local caustic supplies or uneconomic prices for imported materials, that soda ash would be causticized to meet requirements.

The primary question which must be answered is what the supply of caustic will be. The supply of caustic, however, is a function of the demand for chlorine. The latter is largely determined by its end uses in hydrocarbon chlorination reactions. While the bulk of chlorine is used to chlorinate hydrocarbons, there are many processes where the chlorine never ends up in the product but rather is used as an oxidizing or linking agent. Conspicuous examples of this are production of propylene via hydrochlorination, nylon 6.6 by chlorination of butadiene and glycerine via allyl chloride.

Products which are major consumers of chlorine as a constituent are:

* VCM (Vinyl Chloride Monomer);

* Trichlorethylene;

* Phosgene;

* Fluorinated Hydrocarbons;

* Chlorinated Benzene;

* Perchlorethylene.

of these, the largest by far is VCM, since it is the. monomer (building block) for PVC (polyvinyl chloride) which is widely used in coatings, plastic pipe, films and elastomers. Because of its large 
volume, PVC demand is very influential in establishing operating rates for chlorine plants.

VCM is produced by oxychlorination of ethylene with chlorine or by "cracking" (dehalogenating) EDC (ethylene dichloride) to yield $\mathrm{HCl}$ which can then be added directly to ethylene to form more VCM.

Gasoline lead anti-knocks, composed of TEL (tetraethyl lead), TML (tetramethyl lead) or mixtures, are a major market which is likely to disappear under the lead phaseout now required by the EPA unless there is some change in these regulations. One major producer has filed a suit to block implementation of this phasedown in its final form, but at this point it is impossible to predict the outcome.

Additional losses in chlorinated hydrocarbon markets have resulted from the prohibition of DDT manufacture as well as use limitation on certain of the other chlorinated pesticides.

Fluorocarbon bans or reductions, prohibitions on use of PCBS (polychlorinated biphenyls) as transformer fluids, chlorinated solvents and other hydrocarbons based upon chlorine are having significant impact upon total chlorine demand, and by inference caustic supply.

The U.S. advantage in hydrocarbon costs due to price controls on crude oil and natural gas have, together with a lower exchange value for the dollar, given the U.S. a major export advantage which has been reflected in export figures for many chlorinated products or precursors. Each mole of chlorine exported, whatever the form, represents one mole of caustic soda produced. Conversely, each mole of chlorine or equivalent imported represents a mole of caustic not indigenously produced in the importing country. Export trade in chlorinated products thus will have significant effect upon caustic balances, and by inference, soda ash demand.

Plant operating rates are highly influential not only to the company, but often to the government in power. Imports, if they affect operating rates, or force closings, are not likely to be tolerated. U.S. exports of chlorinated products thus are likely to be sharply reduced in the future. 
Domestic production of chlorine related hydrocarbons for selected years is reported in International Trade Commission data as follows:

TABLE 3.58

Ranked U. S. Production of Selected Hydrocarbons Employing Chlorine Millions of Pounds

\begin{tabular}{|c|c|c|c|c|c|}
\hline Type Use & Product & $\underline{1970}$ & $\frac{\text { Production }}{1978}$ & $\underline{1979}$ & $\begin{array}{c}\text { X Annual } \\
\text { Change } \\
1970-1978 \\
\end{array}$ \\
\hline Direct & Ethylene Dichloride & 7,460 & 11,000 & 11,500 & 5.0 \\
\hline "I & $\mathrm{VCM}{ }^{1)}$ & 4,040 & 6,940 & 7,520 & 8.1 \\
\hline Indirect & Propylene Oxide ${ }^{2)}$ & 1,180 & 2,050 & 2,236 & 7.1 \\
\hline Direct & Carbon Tetrachloride & 1,010 & 740 & 700 & $(3.9)$ \\
\hline$"$ & Ethyl Chloride & 680 & 540 & 580 & $(2.8)$ \\
\hline$"$ & Phosgene & 620 & 1,300 & N. R. & 9.7 \\
\hline$"$ & Perclorethylene & 710 & 730 & 770 & 0.3 \\
\hline$"$ & Fluorocarbons (all) & 700 & 730 & 670 & 0.5 \\
\hline$"$ & Trichlorethylene & 610 & 300 & 260 & $(8.5)$ \\
\hline
\end{tabular}

1) VCM employs EDC as the feedstock, requiring approximately 1.65 pounds/pound

2) Propylene oxide via chlorhydrin requires approximately 1.6 pounds of chlorine per pound of P.O. Approximately $40 \%$ of U.S. P.0. Capacity is either dual purpose or uses peroxidation chemistry rather than chlorhydrin.

Source: International Trade Commission

While the majority of hydrocarbon chlorination processes end up with a product containing chlorine, many simply utilize chlorine to perform an oxidation or make possible addition or substitution reactions, as mentioned previously.

One of the most conspicuous examples of this is the production of propylene oxide via hydrochlorination; until the development of direct oxidation processes, ethylene oxide was produced in the same manner, via chlorhydrin. The four largest hydrocarbon consumers of chlorine in 1978 are listed in the table on the following page. 
TABLE 3.59

Imputed Equivalent Chlorine Demand for Selected Hydrocarbon Processes Thousands of Tons

Product

VCM

Propylene 0xide

Phosgene

Carbon Tetrachloride

Perchlorethylene

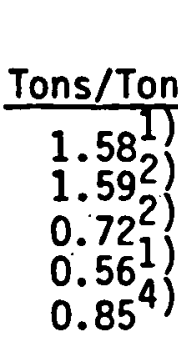

Total

Production

\begin{tabular}{cc}
$\frac{197.0}{2,02.0}$ & $\frac{1978}{5)}$ \\
$530^{\circ}$ & $370^{3)}$ \\
310 & 620 \\
510 & 370 \\
360 & 370 \\
\hline 3,730 & $\frac{370}{5,580}$
\end{tabular}

Equivalent Ch Torine Demand $\underline{1970 \quad \underline{1978}}$ $3,190_{5}, \quad 5,480$ $840^{5)} \quad 1,140$ $220 \quad 470$ $290 \quad 210$ $310 \cdot \quad 310$

1) Chemical Conversion Factors Data: International Trade Commission and Yields, Mimi Erskine, SRI International

2) Industrial Chemicals, 4th Edition, Faith, Keyes and Clark

3) $90 \%$ Chlorhydrin Process assumed

4) Net Chlorine Demand including Trichlorethylene credits

5) $70 \%$ Chlorhydrin assumed

This demand can be compared to total production of chlorine in the U.S. during the same year and in 1970.

TABLE 3.60

Comparison of Chlorine Production and Imputed Consumption in Selected Processes Thousands of Tons

$\%$

\begin{tabular}{|c|c|c|c|c|c|c|c|}
\hline \multirow[b]{2}{*}{ Product } & \multicolumn{6}{|c|}{ Thousands of Tons } & \multirow{2}{*}{$\begin{array}{c}\text { Annual Change } \\
1970-1979 \\
\end{array}$} \\
\hline & 1970 & $\%$ & $\underline{1978}$ & $\%$ & 1979 & $\%$ & \\
\hline $\begin{array}{l}\text { Chlorine } \\
\text { VCM } \\
\text { Propylene Oxide } \\
\text { Phosgene } \\
\text { Carbon Tetrachloride } \\
\text { Perchlorethylene } \\
\text { All Other Uses? }\end{array}$ & $\begin{array}{r}9,760 \\
3,190 \\
840 \\
220 \\
290 \\
310 \\
4,910\end{array}$ & $\begin{array}{r}100 \\
33 \\
9 \\
2 \\
3 \\
3 \\
50\end{array}$ & $\begin{array}{r}11,050 \\
5,480 \\
1,140 \\
470 \\
210 \\
310 \\
3,440\end{array}$ & $\begin{array}{r}100 \\
50 \\
10 \\
4 \\
2 \\
3 \\
31\end{array}$ & $\begin{array}{c}12,100 \\
5,940 \\
1,24911) \\
510 \\
200 \\
330 \\
3,880\end{array}$ & $\begin{array}{r}100 \\
49 \\
10 \\
4 \\
2 \\
3 \\
32\end{array}$ & $\begin{array}{c}2.4 \\
7.2 \\
4.4 \\
9.8 \\
(4.1) \\
0.6 \\
(2.4)\end{array}$ \\
\hline
\end{tabular}

1) Estimate by E. G. Higgins Federal

2) by difference

Source: International Trade Commission; Bureau of Census, Current Industrial Reports; Chemical \& Engineering News, June 9, 1980

As can be seen, vinyl chloride became increasingly critical to chlorine demand in the U. S., accounting for one out of two tons produced in 1978. Other uses also declined; these included motor fuel anti-knock mix due to 
lead phase down, chlorinated pesticides and other chlorine uses such as pulp bleaching.

Exports played an important role in U. S. chlorinated product demand, and much of U.S. exports went to Europe.

In general, it is felt that U. S. exports in 1979 represented a high water mark which is not likely to be repeated. ${ }^{40)}$ In part this is a consequence of competition from Eastern European exports of counterpart trade production, excess capacity in W. Europe itself, and growing resistance to U.S. sourced imports. The latter in part is due to European producers feeling that U.S. price controls on petroleum hydrocarbons are equivalent to raw material subsidies.

World production of PVC for the years 1970 and 1976 was reported to be as follows:

TABLE 3.61

Reported Production of PVC for Selected Producing Nations Thousands of Metric Tons

\begin{tabular}{|c|c|}
\hline Country & $\underline{1970}$ \\
\hline United States & $1 ; 400$ \\
\hline Japan & 1,160 \\
\hline West Germany & 780 \\
\hline Italy & 500 \\
\hline United Kingdom & 320 \\
\hline Spain & 100 \\
\hline Other by Difference ${ }^{\star}$ & 1,010 \\
\hline Total & 5,280 \\
\hline
\end{tabular}

Source: United Nations Statistical Ycarbook

Because of incomplete reporting, or data which cannot be verified, there is some question about the accuracy of the information used. It is felt, however, that the data are sufficiently representative to provide a useful comparison for the purposes of this study. 
It is important to recognize that production of PVC and VCM are not necessarily synonomous for a country, and that there may be significant trading, tolling and other conversions which are effective changes in the chlorine balances for the individual countries with market effect on caustic soda supplies.

World production of caustic soda for the same period and major producing countries are reported as follows:

TABLE 3.62

\begin{tabular}{|c|c|c|c|c|c|}
\hline \multirow[b]{2}{*}{ Country } & \multicolumn{4}{|c|}{$\begin{array}{l}\text { Reported Production of Caustic Soda } \\
\text { for Selected Producing Nations } \\
\text { Thousands of Metric Tons }\end{array}$} & \multirow{2}{*}{ Annual $\%$ Change } \\
\hline & $\underline{1970}$ & $\%$ & $\underline{1976}$ & $\%$ & \\
\hline United States & 9,200 & 41 & 9,200 & 34 & - \\
\hline Japan & 2,600 & 12 & 2,820 . & 11 & 1.3 \\
\hline USSRR & 1,800 & 8 & 2,600 & 10 & 6.3 \\
\hline West Germany & 1,700 & 8 & 3,090 & 12 & 10.3 \\
\hline France & 1,100 & 5 & 1,280 & 5 & 2.6 \\
\hline Italy & 1,000 & 4 & 1,130 & 4 & 2.1 \\
\hline Other & 5,040 & 22 & 6,380 & 24 & $\underline{4.0}$ \\
\hline Tutál & 22,440 & 100 & 26,500 & 100 & 2.8 \\
\hline & & & & Source: & $\begin{array}{l}\text { United Nations } \\
\text { Statistical Hand- } \\
\text { book }\end{array}$ \\
\hline
\end{tabular}

Reporting of caustic production is subject to the same caveats as those applying to PVC data, with the additional caution that production may be significantly greater than reported because of non-conversion of cell liquor to commercial product in the event of an excess of supply over demand.

Chlorine production is a more meaningful indication of caustic supply. Data for the OECD and North American regions is shown in the table on the following page. 
TABLE 3.63

Reported Chlorine Production for Selected Nations

Thousands of Metric Tons

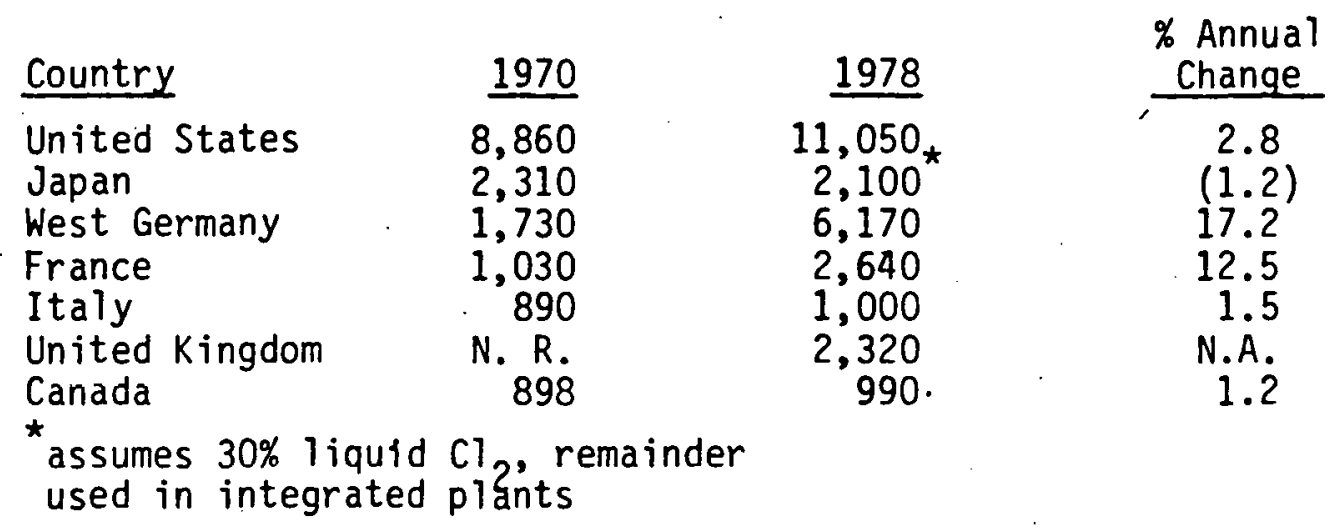

Source: United Nations Statistical Yearbook;

C \& E News, June 9, 1980

Eastern European nations reported the following production figures for selected products.

\section{TABLE 3.64}

\begin{tabular}{|c|c|c|c|c|}
\hline \multirow[b]{2}{*}{ Product } & \multicolumn{3}{|c|}{$\begin{array}{l}\text { Reported Production of Selected Chemicals } \\
\text { by Eastern Bloc Nations }\end{array}$} & \multirow{2}{*}{ Annual ${ }^{*}$ Change } \\
\hline & Nation & 1970 & 1977 & \\
\hline \multirow[t]{2}{*}{ Caustic Soda } & $\begin{array}{l}\text { Bulgaria } \\
\text { Czeckoslovakia } \\
\text { East Germany } \\
\text { Hungary } \\
\text { Poland } \\
\text { Romania } \\
\text { USSR }\end{array}$ & $\begin{array}{r}40 \\
190 \\
410 \\
60 \\
310 \\
330 \\
1,780 \\
\end{array}$ & $\begin{array}{r}100 \\
310 \\
420 \\
80 \\
440 \\
740 \\
2,660 \\
\end{array}$ & $\begin{array}{r}14.0 \\
7.3 \\
0.3 \\
4.2 \\
5.1 \\
12.3 \\
5.9 \\
\end{array}$ \\
\hline & Sub-Total & $\overline{3,120}$ & 4,750 & 6.2 \\
\hline \multirow[t]{2}{*}{ Soda Ash } & $\begin{array}{l}\text { Bulgaria } \\
\text { Czeckoslovakia } \\
\text { East Germany } \\
\text { Hungary } \\
\text { Poland } \\
\text { Romania } \\
\text { USSR }\end{array}$ & $\begin{array}{r}2 \\
12 \\
-\quad 2 \\
19 \\
11 \\
93 \\
\end{array}$ & $\begin{array}{r}1,200 \\
130 \\
900 \\
\text { N. R. } \\
840 \\
860 \\
4,880 \\
\end{array}$ & $\begin{array}{c}>100 \\
40.5 \\
\text { N.A. } \\
\text { N.A. } \\
75.0 \\
87.0 \\
75.0 \\
\end{array}$ \\
\hline & Sub-Total & 139 & 8,810 & 83.0 \\
\hline Total & $\mathrm{Na}_{2} \mathrm{O}$ Pool & 2,450 & 8,720 & 19.8 \\
\hline
\end{tabular}

Source: OECD: The Chemical Industry; European Chemical News, May 14, 1976; East/West Trade - OECD, May 1980 
Chlorinated hydrocarbons represent the single most important factor in world caustic supplies, and PVC is by far the largest chlorinated hydrocarbon in terms of production and consumption.

Its widespread involvement in international trade as EDC, monomer, resin and as finished products represents proxy trade in chlorine, with considerable implications for soda ash.

In general, PVC is becoming an unprofitable product, with enormous overcapacity worldwide. ${ }^{41)}$ In part this is due to sharp declines in demand due to steep decreases in the largest market, PVC pipe used in construction. Many firms now in the PVC business are moving to sell their facilities or even entire divisions. ${ }^{42)}$

The combination of PVC overcapacity in both Western and Eastern Europe, the United States plus new Asian production capacity will create significant strains in world caustic and chlorine balances as producers attempt to keep operating rates up by exports or stockpiling. National companies, such as COMECON producers, who are endeavoring to earn foreign currency as well as keep workers employed may cause significant trade barriers to be erected against all imports, including those of the United States, in order to protect domestic industries.

The outlook is for flattened chlorine demand due to slow PVC sales and poor profitability, with concomitant drops in caustic supplies.

Closing of other chlorine consuming plants such as lead antiknocks will add to the diminished chlorine picture in the U. S.

On the growth side, phosgene demand has grown steadily as its end use market, urethanes, has grown. Heavy dependence upon automobile applications, however, have slowed recent sales. Since polyurethanes also use propylene glycol as a co-reactant with the Di-isocyanate derived from phosgene, urethanes represent a double consumption of chlorine to the extent that the $\mathrm{glycol}$ is derived from chlorhydrin based product. ${ }^{44)}$

Since many caustic soda uses, other than internal use in chlorination reactions and neutralization, are in fairly stable markets such as pulp and paper, soap, textile processing, water treatment, rayon, 
alumina, and chemicals manufacturing, it can be seen that the possibility exists for significant discontinuities to appear in caustic soda supplies and demand. Shortfalls of temporary or relatively small amounts would be met by trading, but larger ones would have to be accommodated by soda ash.

Should Eastern Europe be unable to continue its present level of shipments for whatever reasons, whether fuel interruptions, growing internal needs or simply labor disruptions, Western Europe would be hard pressed to make up deficits.

While current supplies are not only ample, but excessive, and prices low due to severe price cutting, long term the outlook suggests shortages in sodium oxide markets in Western Europe as older plants are phased out without new production capacity being installed. ${ }^{45)}$

The consequences of growth in counterpart trade, changes in manufacturing costs for derivative products and energy costs will be discussed. in the following section.

In summary, caustic soda end use, other than chemicals, by major. category is approximately as follows:

$$
\begin{aligned}
& \text { * alumina; } \\
& \text { * pulp and paper; } \\
& \text { * rayon; } \\
& \text { * soap. }
\end{aligned}
$$

The imputed world consumption of caustic soda for the above uses for selected years is as follows:

\section{TABLE 3.65}

$$
\begin{aligned}
& \text { Imputed Consumption of Caustic Soda } \\
& \frac{\text { By Selected End Use }-1977}{\text { Thousands of Metric Tons }}
\end{aligned}
$$

End Use Use Ratio Production Caustic Demand $\quad$ Caustic

$\begin{array}{llllr}\text { Alumina } & 0.0601 \mathrm{~b} / 1 \mathrm{~b} & 29,4101) & 1,760 & 6.7 \\ \text { Pulp and Paper } & 0.0501 \mathrm{~b} / 1 \mathrm{~b} & 87,0002) & 1,740 & 6.6 \\ \text { Rayon Sub-Total } & 1.01 \mathrm{~b} / 1 \mathrm{~b} & 3,200^{2} & \frac{1,600}{5,100} & \frac{6.0}{19.2} \\ \text { Total Caustic Production } & & & & 100.0\end{array}$

1) Total chemical pulp; assumes $40 \%$ bleached, 1976 data.

2) Total rayon and acetate fiber and filament; assumes $50 \%$ rayon. 
Any of the above categories could be significantly larger consumers of caustic than imputed, based upon the actual process and proportions. Alumina caustic demand is strongly influenced by the type ore used and its proportion of mono to trihydrate ratio. Pulping caustic consumption is influenced by the pulp source, degree of brightness, bleach sequence and proportion of bleached to unbleached pulp as well as efficencies.

Rayon consumption of caustic does not vary greatly by process, but the method of reporting includes both rayon and acetate fiber production because of their raw material base in cellulose. (This distinguishes man made fibers from synthetics such as nylon, acrylic, polyolefin and polyester.)

Nahcolite

Potential nahcolite markets can be segregated into two categories:

* Stack Gas Scrubbing (SGS);

* Semi-Finished Ash.

SGS markets are dependent upon four primary factors:

* availability of compatible hardware;

* envirnnmental acceptability;

* competitive cost;

* reliability.

Use of dry products such as soda ash or nahcolite is highly desirable from the standpoint of process simplicity. For utilitics who form the primary SGS market, complex chemical processes with high energy costs are not desirable if other alternatives exist. Sodium products, such as soda ash or nahcolite, are the only ones with sufficiently fast reaction times to permit dry scrubbers. Dry scrubbers require bag houses, however, to capture the resulting sodium/sulfur reaction products. If the utility has ESP (Electrostatic Precipitator) units, they will be reluctant to install redundant bag houses as well to control particulates resulting from scrubbing $\mathrm{SO}_{2}$. 
Nahcolite and soda ash reaction products are soluble in water, hence must be converted to an insoluble form for disposal; if not converted to gypsum, they must be disposed of in a manner which will insure there will be no leaching of the product into the subsoil. Sludge disposal is a major cost and technical problem to SGS systems, so that this cost would be additive. ${ }^{46)}$

The competitive cost would have to include not only the hardware, but the operating cost and neutralizing agent. If limestone $\left(\mathrm{CaCO}_{3}\right)$ were $\$ 20 /$ ton, at $70 \%$ completion of the reaction, the chemical cost per ton of $\mathrm{SO}_{2}$ would be $\$ 44$. Nahcolite at $80 \%$ active, $\$ 40 /$ ton delivered (10\% under soda ash equivalent, FOB works) would have a chemical cost of approximately $\$ 128 /$ ton of $\mathrm{SO}_{2}$. If there were a chemical value which could be derived from recovery of the sodium oxide, this could be used as an offset against the nahcolite. If not, then the choice would have to be based upon the economic and operating advantages of a dry vs wet scrubber.

The final consideration is reliability. Unless the SGS system has the same or greater reliability as the predecessor power boiler and generating system, it will not be acceptable to a utility because of the risk. The acceptability of technology is thus a trade-off in compliance vs operating risk. Assurance of supply is a risk component, so that it is difficult to forecast the outcome.

Compliance with emission criteria have employed three major approaches:

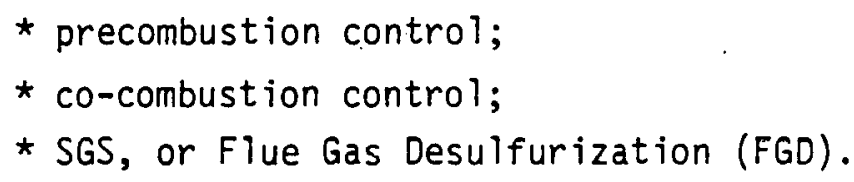

Precombustion controls have consisted of using compliance fuels. As long as the fuel cost is a pass through in the rate calculation, there is no reason not to use higher cost, higher quality fuels. Where DOE regulations forced conversion to a specific fuel such as coal to conserve. natural gas or petroleum, the utility was required to either get waivers until equipment could be installed or close the station.

A great deal of time and money has been spent to develop methods to remove sulfur from coal, or the carbon from the coal, but so far most 
systems have not been technical nor economic successes. It is possible that this picture may change, however.

Petroleum desulfurization technologies have been known and used for many years, but are fairly costly in capital and hydrogen.

Post combustion systems have, with few exceptions, been lime based wet scrubbers. The major questions are what future power requirements will be and, what proportion will be supplied by nuclear vs fossil fuel sources. Since this question directly affects the scrubber requirements, the outcome is very difficult to predict.

Co-combustion, or Fluidized Bed Combustion (FBC) has been put into pilot operations successfully, and appears to have the best potential at this time if there are no unusual operating problems which cannot be solved. The basic approach is to inject limestone along with a powdered coal fuel, or 0il/coal mixtures, into the boiler. At elevated temperatures and with finely ground lime and coal in intimate contact, the sulfur is burned to $\mathrm{SO}_{2}$ and reacts with the decarbonated limestone simultaneously. The resulting molten reactants are then rejected with the ash, or noncombustibles in the coal, in the form of slag.

As long as there is uncertainty in the fuel systems, the basic demand for electricity, and the technology for control of emissions. it is unlikely there will be a significant market for nahcolite because the basic decision mechanism is too diffuse to make a rapid committment to any one technology.

Semi-Finished Ash Markets

Semi-finished ash would be a product intermediate between the as-mined ore and finished ash from a trona, oil shale or Solvay plant. In the case of trona, it is possible that the "product" would be utilized in some applications with little processing beyond grinding. It is believed that there will be little real potential because of the importance of physical uniformity to the glass industry, as well as the unacceptability of contaminants such as iron or other coloring agents.

In the case of nahcolite, it would first be necessary to calcine the raw ore to convert it to a form roughly comparable in $\mathrm{Na}_{2} \mathrm{O}$ content to 
raw trona. Decarbonation of bicarbonate of soda is energy intensive, and use of limited energy sources to produce an inferior product which would have to sell at a discount in competition with finished ash does not appear to have economic merit.

Freight is at least as influential as mining and conversion to the market economics. Effectively each percent reduction in contained $\mathrm{Na}_{2} \mathrm{O}$ means that much higher total cost of active material due to freight charges on the inactive portion. If the difference in $\mathrm{Na}_{2} \mathrm{O}$ content between semifinished and finished ash were only three percentage points ( $55 \% \mathrm{Na}_{2} \mathrm{O}$ vs $58 \%$ ), that difference would be equal to $\$ 0.94$ per $\$ 10.00$ of freight per short ton of delivered ash.

Semi-finished product would not be likely to be competitive with finished ash on a delivered basis because of the effect of freight on semi-finished economics. The manufacturing costs are not likely to be sufficiently lower for semi-finished ash to compensate for the competitive discounts to make the lower quality product market acceptable.

Semi-finished material thus would be squeezed between higher freight per ton of $\mathrm{Na}_{2} \mathrm{O}$ and lower overall selling prices.

The one exception which might be envisioned is if European Solvay process producers were to purchase semi-finished product for final conversion in existing plants. In any event, it would be necessary to evaluate whether trona might be as easily shipped.

\section{Economics and Logistics}

Discussion

Chemical commodity economics are often highly dependent upon freight and associated logistic costs such as terminalling. This is particularly true of the products associated with oil shale mineral recovery, viz, alumina, soda ash and nahcolite.

Figures 1-6 display the relationships between an oil shale based mineral source and major consuming locations and competitive shipping points.

The majority of alumina, aluminum, chlorine and soda based 
inorganic chemical plants are located on water, a matter of economic significance to a land locked facility such as an oil shale plant.

Water movement is a matter of considerable importance to soda ash and alumina economics from oil shale because competitive sources and customers both utilize barges and ship transportation.

Caustic soda, a major competitor of soda ash in many markets, is shipped as a $50 \%$ solution as a rule; this means that a ton of water is shipped along with a ton of caustic soda. While the FOB works pricing ignores the water, being on a contained $\mathrm{Na}_{2} \mathrm{O}$ basis, the freight is charged on the entire weight. The effect upon the respective $\mathrm{Na}_{2} \mathrm{O}$ basis prices can be seen in the example following.

TABLE 3.66

Effect of Freight

on Competitive Delivered $\mathrm{Na}_{2} \mathrm{O}$ Costs

for Nahcolite, Soda Ash and Caustic Soda

\begin{tabular}{|c|c|c|c|c|}
\hline Product & $\mathrm{Na}_{2} \mathrm{O}$ Content & $\begin{array}{c}\text { Base } \\
\text { Freight } \\
\end{array}$ & $\begin{array}{c}\text { Effective } \\
\text { Rate } \\
\end{array}$ & Rate/Ton $\mathrm{Na}_{2} \mathrm{O}$ \\
\hline Caustic Soda & $76 \%$ & $\$ 10 /$ Ton & $\$ 20$ & $\$ 26.31$ \\
\hline Soda Ash & $58 \%$ & $"$ & $\$ 10$ & $\$ 17.24$ \\
\hline Nahcolite (80\%) & $28 \%$ & $"$ & $\$ 10$ & $\$ 35.71$ \\
\hline
\end{tabular}

Source: E. G. Higgins Federal

The significance is that oil shale mineral plants will not be close to markets, but fairly distant, with the exception of Northwest aluminum smelters, where the colorado based plant could have a real advantage if freight rates can be developed on a competitive basis.

Overland alumina rates would have to be competitive with shipping from U. S. Gulf ports to the Northwest via the Panama Canal, or from Australia via ship.

Caustic soda is frequently moved via barge, so that the concentration plays no real role in delivered costs. The cost of movement via various transportation methods varies considerably, with trucks the most costly, rail car next, unit train next and barge or ship the lowest. 
Water movement costs are relatively insensitive to distance on a unit basis, but are fairly responsive to scale.

Land movement, especially by truck, is distance sensitive. Rail movement costs vary considerably by whether the shipment is by individual car, unit train or blocked cars.

Equipment type also plays a role. Specialized or dedicated equipment is more costly since its utilization presumably is lower. Ownership of the rail equipment is a factor as well, since the rate can be lower if the owner is responsible for providing the car.

A comparative listing of typical logistic costs are shown in the table below, based upon a study of transportation costs between 1965-1974.

TABLE 3.67

Transportation Costs by Selected Method \$/Ton

\begin{tabular}{|c|c|c|c|c|}
\hline \multirow[b]{2}{*}{ Product } & \multirow[b]{2}{*}{ Method } & \multicolumn{3}{|c|}{ Distance in Miles } \\
\hline & & $\underline{250}$ & $\underline{500}$ & 1000 \\
\hline \multirow[t]{3}{*}{ Crude $0 i 1$} & VLCC 100,000 Tons & - & - & 1.02 \\
\hline & Tanker $25,000 "$ & 3.24 & 2.03 & 1.22 \\
\hline & Barge & 3.24 & 2.44 & 1.62 \\
\hline \multirow[t]{4}{*}{ Coal } & Collier & 2.40 & 2.16 & 1.92 \\
\hline & Hopper Car & 1.20 & 0.78 & - \\
\hline & Railroad Car & 0.48 & 0.42 & - \\
\hline & User Car & 0.36 & 0.34 & - \\
\hline 0 ii. & Truek & 2.90 & - & - \\
\hline
\end{tabular}

Source: Sourcebook for Energy Assessment, Brookhaven National Laboratory

While current costs are far higher than these, primarily because of fuel charges, the basic relationship remains essentially the same. The most important point is that water movements are all negotiated, usually unpublished rates, while rail charges are based upon intricate and highly arcane cost analyses. Not infrequently, the rate is strongly influenced by the ability to move the product by an alternate method, such as barge. 
Rates which meet this type of competition are termed "water compelled" rates.

The significance to oil shale mineral economics is that the logistic expenses of moving soda ash, nahcolite and alumina to market are very important, and can determine whether the products are competitive with other sources.

Because there are no movements at this time, it is difficult to provide a reasonable basis for estimating charges, but presumably the rates published from Green River, Wyoming to various destinations should be representative.

For a direct line distance of 1,140 miles, there is a 190,000 pound rate of $\$ 42.50$ on soda ash from Green River, Wyoming to Galveston, Texas, or about $0.04 \$ /$ ton mile. Unit train rates to $S t$. Louis are more favorable, but comparable.

It is likely that alumina rates might be higher, and nahcolite could move at mineral ore rates, which tend to be lower.

The point is that transportation economics are not only very complex, they have little real predictability, and they form a large unknown element in the economics of land locked production. In the case of alumina, they are very important because, as in the situation with caustic soda, two tons of product must be moved in terms of ingot aluminum. 
INTERPRODUCT COMPETITION AND TRADE IMPACT UPON SODA ASH AND ALUMINA MARKETS

\section{A. Interproduct Competition}

Products compete primarily in their functional cost to the purchaser. The functional cost is that which considers not only the unit price, but the impact of density differentials and ancillary labor, freight and other charges upon the effective as used cost.

Displacement or substitution of products from markets seldom takes place rapidly unless there is an overwhelming cost or other marketing advantage by the new product. Once the substitution has been made, however, it is very unusual for a reversal to take place unless the primary product is not available to meet market demand.

In terms of oil shale mineral markets, substitution on a meaningful scale is most likely to be confined to a relatively few markets:

\section{TABLE 4.1}

Interproduct Market Matrix

:

$\geq$

\pm Product

- Aluminum

Stee 1

Major End Use Transportation Chemicals Containers Pulp \& Paper Construction

Metals

Plastics

Polyester

Polyethylene

Polypropylene

Polyvinylchloride

Urethanes

Glass

\section{$x$}

$x$

$x$

$x$

$x$

$x$

$x$

$x$

$X$

$x$

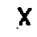

$x \quad x$

$x$

$x$

$x$

$x$

$x$

$x$

$-$

$x$

$x$

$x$

$x+x$

$x$

$x$

$x$

$x$

Chemicals

Soda Ash

Caustic

\footnotetext{
Source: E. G. Higgins Federal

of the markets, the most important to oil shale minerals is containers, since both aluminum and glass are major end uses of potential mineral products from oil shale.
} 
Container cost is a major consideration to packers, but not the only one. Freight, market acceptability and ownership of. producing facilities are also important, and sometimes determining variables. Representative costs for selected containers, as reported in Census Bureau data, are compared below:

TABLE 4.2

Reported Shipment Values for Selected Containers by Material

$\$ /$ Thousand Containers

Material

Aluminum

Stee 1

Glass
Use

all

all

Narrowneck Widemouth
1970

71.30

41.95

N. R.

N. R.
1978

80.67

92.52

89.70

82.10
$\%$

Change

1.6

10.4

Source: Bureau of Census Current Industrial Reports

One significant factor is the effect of density differentials, or weight per container, upon delivered costs. Another is the ability to fabricate on site, so that container raw materials can be shipped flat, as in can stock. Beverage packers are usually ton small to support a captive can plant, but brewers, because of their large volume per plant almost always have on site container facilities.

It should be noted that the above data are averages for all containers, which in the case of narrowneck glass bottles encompasses a wide range of products, including liquor and wine. In contrast, a much higher percentage of aluminum and steel containers are accounted for by 12 ounce beverage and beer sizes. Value data for individual container categories are not published by the Bureau of Census, but it is probable that glass and aluminum are very competitive.

Container weight influences packaging economics by freight costs, as mentioned earlier. Representative data are shown in the table found on the following page. 
TABLE 4.3

Weight Comparisons for Selected Container Materials

\begin{tabular}{clcr} 
Material & Type Container & $\begin{array}{c}\text { lb/Thousand } \\
\text { Containers }\end{array}$ & $\begin{array}{r}\text { Containers/ } \\
\text { Thousand 1b }\end{array}$ \\
\cline { 2 - 3 } & Average, all & 71.6 & 13,970 \\
Steel & Average, all & 171.8 & $5,820$. \\
Aluminum & Soft Drink & 100.0 & 10,000 \\
" & Beer & 59.3 & $16,860$. \\
Glass & Narrowneck Average & 629.0 & $1,590$. \\
" & Beverage, Non-Returnable & $658.0^{*}$ & 1,520 \\
" & Beer, Non-Returnable & 455.0 & 2,200
\end{tabular}

* 1979 Weight

Source: E. G. Higgins Federal from Bureau of Census Data

Metal statistics were no longer collected by the Bureau of Census after 1978, so this year was selected as the last available for comparison. As can be seen, aluminum soft drink containers are only $15 \%$ of the weight $\because \quad$ of an equivalent non-returnable glass container. Comparisons between stee 1 - and aluminum container weights as reported are not meaningful because of

$\because \quad$ the variety of steel containers included in the category.

$=\quad$ The weight advantage is greater in the non-returnable beer con-

tainer category, where aluminum is only $13 \%$ of the weight of an equivalent glass container.

The imputed values per pound for selected materials and containers are shown below:

TA.BLE 4.4

Imputed Costs per Pound for Selected Containers and Materials

\begin{tabular}{|c|c|c|}
\hline Material & Containers & $\begin{array}{l}1978 \text { Cost } \\
\text { per Pound }\end{array}$ \\
\hline Aluminum & Average, all & $\$ 1.13$ \\
\hline Stee 1 & Average, a 11 & 0.54 \\
\hline Glass & Narrowneck Average & 0.14 \\
\hline
\end{tabular}

E. G. HIGGINS FEDERAL 
The functional costs on a per pound basis are approximately the same for the materials cited because their per pound costs are very close to being in the same ratio as their densities. Steel has begun to lose ground to aluminum, however, because steel can technology at present requires three pieces to fabricate - a top, bottom and side. Aiuminum can be deep drawn and requires only two pieces, so that fabrication costs are lower.

Can stock for both aluminum and steel can be shipped flat, so that a single truckload can haul a very large number of containers:

TABLE 4.5

Containers per Truckload

Material

Aluminum, Beer

Steel, average

Glass, Beer Non-Returnable

*

* $50,000 \#$ Net Weight assumed
Containers/Thou Pounds

16,860

5,820

2,200

Source: E. G. Higgins Federal from Bureau of Census Data

As can be seen, the effect of freight is significant since a single truckload of aluminum can stock would represent the same number of containers as 7.5 truckloads of glass.

The same advantage exists with respect to stee1, where 2.9 truck loads are required to move an equivalent number of containers.

This summary disregards the packaging weights for the containers, since the purpose is simply to illustrate the effects which container weight differentials have upon shipping costs. It is assumed that the products compared will not all have the same freight rate per thousand pounds, since this would be the case for captive shipment.

While containers provide the most graphic example of the economic interplay between competitive materials in a given market or end use, automotive products have the most complex cost analyses because of the role that manufacturing inputs other than raw materials play in final cost of a finished product. 


\section{B. Manufacturing Economics}

There are three major cost parameters for products which go into containers and automotive products:

$$
\begin{aligned}
& \text { * Labor; } \\
& \text { * Energy; } \\
& \text { * Raw Materials. }
\end{aligned}
$$

The energy demands for glass, steel and aluminum are fairly high, as has been discussed.

Hydrocarbon based products such as plastics and resins have both high raw material costs as well as energy requirements. The densities of the finished products are very low, however, so that the apparent disadvantage is greater than the actual.

The relative energy requirements for several selected materials are shown in the table below.

\section{TABLE 4.5}

Energy Requirements For Selected Container Materials

$$
1970
$$

Material

Aluminum, Ingot

Steel, Pig Iron

Glass, Container

High Density Polyethylene Resin

PVC Res in

\section{Energy Requirements}

139 1 ) MMBTU/Ton

$18^{2)} \quad "$

$12^{3)} \quad "$

$74^{4)} \quad 1$

$70^{5)} \cdot 1$

1) Excludes mining. Includes alumina and aluminum only, all energy forms.

2) Excludes mining energy.

3) Glass containers - no mining or raw material demand.

4) For ethylene and resin production only. Does not include refining.

5) Includes caustic/chlorine, ethylene, oxygen. All energy forms included.

Source: The Potential for Energy Conservation in Mine Selected Industries, Gordian Associated, Inc; FEA, June 1974; PB 243-618 
The above data are for direct conversion costs only, and do not include mining or other offsite energy needs, which would be additive. The data are from 1970, and it is believed 1980 demands would be significantly lower for many products, especially plastics. Steel and aluminum would require additional energy inputs for rolling into sheet and container manufacture.

Glass energy demands are unlikely to drop very much simply because the plants are relatively old and the process is not amenable to easy heat conservation or recovery.

The primary factors affecting energy costs are the quality and fuel. Aluminum not only has a high energy demand, it has the highest quality energy needs, electricity. Steel is almost entirely coal based, while natural gas fuels $90 \%$ of U. S. glass plants. ${ }^{47)}$ Glass energy costs, therefore, are likely to be the most stable because of price controls on natural gas.

Plastics and resins are entirely based upon petroleum hydrocarbons and are likely to experience the greatest cost volatility as a result.

Of the major container materials, glass appears to have the greatest advantage in energy costs long term. provided it is not necessary to shift to other fuels. A brief summary of estimated glass costs per ton are shown in the table following.

TABLE 4.6

$\frac{\text { Imputed Soda Lime Glass Cost }}{\text { Per Ton of Container Glass }}$

\begin{tabular}{|c|c|c|c|c|c|}
\hline Cost Center & Detail & Feed & & Assumed Price & $\begin{array}{l}\text { Cost to } \\
\text { Glass } \\
\end{array}$ \\
\hline Raw Material & $\begin{array}{l}\text { Glass Sand } \\
\text { Soda Ash } \\
\text { Limestone } \\
\text { Feldspar } \\
\text { Saltcake } \\
\text { Cuillet }\end{array}$ & $\begin{array}{l}0.67 \\
0.22 \\
0.22 \\
0.08 \\
0.06 \\
0.20 \\
1.45\end{array}$ & $\begin{array}{l}\text { Tons } \\
1 " \\
" 1 \\
11 \\
11 \\
1 "\end{array}$ & $\begin{array}{r}\$ 10.00 \\
110.00 \\
10.00 \\
50.00 \\
40.00 \\
30.00 \\
\end{array}$ & $\begin{array}{r}\$ 6.70 \\
24.20 \\
2.20 \\
4.00 \\
2.40 \\
6.00 \\
\$ 45.50\end{array}$ \\
\hline $\begin{array}{l}\text { Energy } \\
\text { Total Direct }\end{array}$ & $\underset{t s}{\text { Natural Gas }}$ & $12 \mathrm{MCF}$ & $"$ & 2.50 & $\begin{array}{r}30.00 \\
\$ 75.50\end{array}$ \\
\hline
\end{tabular}

* does not include labor, taxes, insurance, utilities or capital charges.

Source: Chemical Process Industries, Shreve;

Encyclopedia of Process Industries, Kirk \& Othmer;

The Potential for Energy Conservation in Nine

Selected Industries, Gordan Associates, Inc.

PB 243-618

E. G. HIGGINS FEDERAL 
The costs in Table 4.6 may vary considerably depending upon 10cation, especially for soda ash, which has a large freight component in its finished cost.

Energy costs may vary considerably, but it is believed that at present \$2.50/MCF (MMBTUs) is a reasonably current price for interstate natural gas for industrial users.

Container glass labor requirements are fairly high because of the combination of maintenance, mold shops and inspection, packing and shipping personnel needs. The division between the glass plant and container plant, however, is not germane to this particular discussion. Recent technological innovations in glass production include the use of "booster" electric heaters which can increase production as much as $40 \%$. ${ }^{48}$ )

Raw material losses on feed other than cullet are about 15-16\% due to moisture and $\mathrm{CO}_{2}$ removal. Cullet (broken glass) does not have any loss. Use of cullet will reduce ash and other raw material needs, but its price is highly variable, as well as its quality. Generally, where quality is critical, "home"cullet or classified cullet is used.

The long term outlook is for glass containers to be less volatile in cost increases than plastics or metals, especially aluminum. An ameliorating factor in aluminum costs, however, is the effect of secondary recovery. If the shipper is also the can manufacturer and scrap collector, as is the case with one large western brewer, the net cost of aluminum will be very much lower than any alternative material.

Primary aluminum is likely to experience the greatest increase in packaging costs unless a domestic alumina source is created. This is due to the effect of the $7.5 \%$ IBA tax upon contained aluminum in bauxite and alumina, referenced to the selling price of ingot. Primary aluminum ingot prices are likely to rise because of increases in power costs for reduction. Every effort to recoup additional costs will in effect raise the ante $7.5 \%$. This will continue as long as the tax is levied on foreign aluminum bearing raw material, or until a domestic supply is available.

Steel is labor, energy and capital intensive, and is faced with massive expenditures to bring outmoded plants up to date, as well as to 
comply with environmental standards in existing facilities.

Chemicals

The bulk of sodium oxide consuming chemicals, phosphates, sodium silicates, chromates and bicarbonate of soda are likely to experience relatively slow growth, or even declines, although the outlook for bicarbonate is better than for the other products.

\section{Pulp and Paper}

Pulp and paper uses of soda ash may increase marginally to substitute for salt cake, but overall chemical uses are likely to continue to drop as mills make strenuous efforts to comply with environmental regulations.

Pulp use of caustic will probably decline after 1984 as chlorine use is sharply reduced to eliminate discharge of chlorinated hydrocarbons. The balanced use of ECUs in pulp bleaching means that reduction of chlorine use will not affect caustic balances overall.

\section{Caustic Substitution}

The largest single ash potential market is for meeting caustic shortfalls resulting from low chlorine demand, if this occurs.

If of the $12,300,000$ short tons of caustic produced in the U.S. : only a $2 \%$ shortfall were to result between supply and demand, 325,000 tons of ash would be required as an $\mathrm{Na}_{2} \mathrm{O}$ equivalent.

The three most influential variables in caustic supply and demand are:

$$
\begin{aligned}
& \text { * VCM demand; } \\
& \text { * export trade; } \\
& \text { * alumina production. }
\end{aligned}
$$

Trade is the means by which discontinuities between supplies and needs for individual countries can be balanced. If there are significant impediments to the movement of products between international markets, then imbalances will be exacerbated. 


\section{Foreign Trade Imbalances}

The major questions which cannot be answered at this time are how reliable a supplier COMECON producers will be to Western Europe, and how protective Western Europe will be of domestic producers of ash and chlorinated products.

If COMECON countries are unable to meet demand, then the possibility of significant opportunities for new soda ash sources, especially low cost ones, will open if there are no major blocks to entry.

E. Alumina

One of the most significant advantages a domestic alumina source would have is that the cost would be decoupled from foreign tax formulae.

Since these are expotential in their cost effects, being tied to increases in the finished product price rather than mined product, use of foreign alumina guarantees a "piggyback" increase on raw material costs even though real costs may not rise at that rate.

Shale is virtually the only way which the U. S. can hold primary aluminum costs within competitive bounds, and affords a real advantage in world markets where other producers must use IBA material.

F.

The market potential for oil shale minerals derivatives, e.g., alumina, soda ash and nahcolite, is very much dependent upon the role of government, both foreign and domestic, in access and ecunumics.

The potential for soda ash is going to be primarily a function of whether there will be access to the Western European market. The Japanese market is somewhat different in that they employ a modified Solvay technology which generates by-product ammonium chloride used as a rice crop fertilizer.

The Western European market avaidability, in turn, is a function of several factors:

\footnotetext{
* reducing Solvay process costs;

* protectionist efforts by producing nations;

* Eastern European marketing policies and production capability.
} 
A secondary element in the outlook for soda ash demand is what the relative balances in caustic soda supply and demand will be, largely a function of chlorine demand, especially for VCM.

On balance, the outlook for natural and oil shale soda ash appears somewhat better than the overall sodium oxide market picture, which is for fairly low growth. This favorable interpretation is based upon the following assumptions:

* Solvay process costs will become too high to compete;

* Eastern Europe production will not be permitted to degrade the price structure below U. S. competitive pricing ability;

* U. S. production will have access to the market;

* chlorine demand will continue at a lower level than caustic, requiring ash substitution.

Alumina is a high potential product because of its inherent advantages on the basis of security of supply, freedom from offshore tax policies of supplier nations, and to a lesser degree, location.

The potential supply would be well within the ability of U.S. domestic ability. to absorb, and the limiting case for demand will be electric power availability for primary aluminum production.

Nahcoltte markets are affected by many considerations, but the most important is that the choice of scrubbing agent is based upon a complex interchange between utility, equipment and process vendors, and government reguiations, both State and Federal.

In addition to the diffuse decision authority, freight plays a very important role in delivered costs of $\mathrm{Na}_{2} \mathrm{O}$. Since nahcolite is only $28 \% \mathrm{Na}_{2} \mathrm{O}$ at $80 \%$ contained bicarbonate of soda, it is necessary to haul about two times the weight of material per ton of $\mathrm{Na}_{2} \mathrm{O}$ as with soda ash.

If the spent nahcolite could be resold at some price to pulp mills, there would be credits available against raw chemical costs. These markets are largely in the South and Southeast U. S., however, and freight charges would be likely to be high, and indigenous by-product salt cake from rayon production available. The most influential factor, however, 
is the trend toward reduction of chemical demands, together with using soda ash or caustic for $\mathrm{Na}_{2} \mathrm{O}$ makeup.

It would appear the market is between $700,000-1,000,000$ tons of nahcolite by 1990, a large part of it in areas close to the source where freight charges will be minimal and the inherent advantages of dry scrubbing applicable. 
V. PROJECTIONS

Alumina

The demand for alumina is related directly to the market for primary aluminum, the dominant source of aluminum metal.

Primary aluminum and its precursors, bauxite and alumina, are international products to almost the same degree as petroleum, although of a vastly lower volume. When secondary aluminum trading is added to that of the primary aluminum materials grouping, the total becomes quite substantial.

The U. S. Bureau of Mines, Non-Ferrous Metals Division, has made projections for domestic and world demand for aluminum by category for the years 1985 and 2000 from a 1976 base. A summary of this table is shown below.

TABLE 5.1

Summary of U.S. and World Alumina Demand Millions of Short Tons.

Market Metal Assumed Annual 1976 Base Probable Demand United States Primary 5.2 Total ${ }^{\star}$

$10.7 \quad 20.0$

Rest of World

Primary

5.7

10.6

21.140 .0

Secundary

8.6

0.6

$1.2 \quad 4.0$

Total*

5.8

12.9

$25.1 \quad 50.0$

World Total

Primary

5.5

15.3

$29.9 \quad 55.8$

Secondary

7.9

1.0

2.16 .0

Total ${ }^{\star}$

5.7

18.7

$35.8 \quad 70.0$

* includes non-metal uses which were r:ct listed separately for brevity. Totals may not add due to independent rounding

Source: Mineral Commodity Profiles, MCP-14; U. S. Bureau of Mines 
The United States is by far the largest producer and consumer of aluminum in the world, as was shown earlier. Not only is the United States the largest producer of both primary and secondary metal, but relatively little is exported. This is in contrast to other market economy based producing nations, most of whom export their output directly as metal. In addition, much of their internal consumption indirectly ends up being exported as finished products.

The projections published in the preceding study may be compared to the actual experience of the United States in the years 1970 and 1979, as seen in the table below.

TABLE 5.2

$\frac{\text { U. S. Salient Statistics for Aluminum Metal }}{\text { Millions of Short Tons }}$

\begin{tabular}{|c|c|c|c|c|}
\hline Item & Type & $\underline{1970}$ & 1979 & Annual ${ }^{*}$ Change \\
\hline \multirow[t]{3}{*}{ Production } & Primary & 4.0 & 5.0 & 2.5 \\
\hline & Secondary & 0.8 & 1.7 & 8.7 \\
\hline & Total & 4.8 & 6.7 & 3.8 \\
\hline Imports & - & 0.5 & 0.8 & 5.4 \\
\hline Exports & - & 0.6 & 0.7 & 1.7 \\
\hline \multicolumn{2}{|c|}{ Apparent Consumption, all } & 4.7 & 6.8 & 1.7 \\
\hline
\end{tabular}

Source: Bureau of Mines

It should be noted that secondary metal data referred to in the Bureau of Mines projections are based upon aluminum metal content, whereas production data are for all secondary metal compositions, which include alloying materials. According to Bureau of Mines comparable data, net aluminum content of secondary metal in 1970 was reported as being 200,000 tons $(0.2$ million), whereas the gross secondary metal production was reported as 0.8 million tons.

Since aluminum is almost always alloyed in order to alter the metal properties, usually to add hardness, the apparent consumption figures will be comparable for the purpose intended.

Between 1976 and 1979, apparent U. S. consumption increased 5.5\%, a slightly higher figure than that used for an assumed annual growth rate. 
Table 5.2, however, showed a much lower annual rate of $4.2 \%$, but which included some recession "in 1979.

Using the 1970-1979 growth rates for each category of data, and projecting from the 1979 base, the 1985 and year 2000 figures would be as follows:

TABLE 5.3

Projected U. S. Salient Statistics

for Aluminum Metal

Millions of Short Tons

\begin{tabular}{|c|c|c|c|c|c|}
\hline Item & Metal & $\begin{array}{c}1970-1979 \\
\text { Annual Growth } \\
\text { Rates } \\
\end{array}$ & $\begin{array}{l}1979 \\
\text { Base } \\
\end{array}$ & $\begin{array}{l}\text { Projected } \\
1985 \\
\end{array}$ & $\begin{array}{l}\text { Data } \\
2000 \\
\end{array}$ \\
\hline Production & $\begin{array}{l}\text { Primary } \\
\text { Secondary } \\
\text { Total }\end{array}$ & $\begin{array}{l}2.5 \% \\
8.7 \\
3.8\end{array}$ & $\begin{array}{l}5.0 \\
1.7 \\
6.7\end{array}$ & $\begin{array}{l}(5.8) \\
(2.8) \\
(8.4)\end{array}$ & $\begin{array}{r}(8.4) \\
(9.8) \\
(14.7)\end{array}$ \\
\hline $\begin{array}{l}\text { Imports } \\
\text { Exports }\end{array}$ & - & $\begin{array}{l}5.4 \\
1.7 \\
\end{array}$ & $\begin{array}{l}0.8 \\
0.7 \\
\end{array}$ & $\begin{array}{l}(1.1) \\
(\underline{0.8})\end{array}$ & $\begin{array}{l}(2.4) \\
(1.0)\end{array}$ \\
\hline \multirow{2}{*}{\multicolumn{2}{|c|}{ Summed Apparent Consumption. }} & 4.2 & 6.8 & $(8.7)$ & $(16.2)$ \\
\hline & & - & 6.8 & 8.9 & 19.6 \\
\hline
\end{tabular}

* The projections are independent, and do not add as a result.

Source: E. G. Higgins Federal from Bureau of Mines Data

The number of merit is primary aluminum production, since this is the principal market for alumina. Based upon the projected data for primary alumina demand would be as follows, assuming 1.95 tons of alumina per ton of primary metal.

TABLE 5.4

Imputed U. S. Alumina Requirements

for Production of Primary Aluminum Millions of Short Tons

Primary Metal Production

1985

5.8

$\underline{1990}$

$\underline{2000}$

8.4
Alumina Equivalent Demand

$\underline{1985} \quad \underline{1990} \quad \underline{2000}$

$\begin{array}{lll}11.2 & 12.9 & 16.4\end{array}$

Source: E. G. Higgins Federal 
The significance is that it will be necessary to import substantial quantities of alumina, or expand capacity greatly, or both, to attain the projected smelter requirements, since domestic nameplate alumina capacity is approximately eight million short tons. ${ }^{49)}$ Nameplate capacity, however, is often not indicative of actual, being larger as a rule. Using the typical industry on stream factor of 0.95 , and assuming variations in recovery efficiencies, it is more likely that the actual capacity is about seven million tons, if it is presumed the reported capacities are representative of the facts and not understated.

In 1979, the United States imported 4.5 million short tons of alumina, and required 9.8 million tons for primary metal. Exports were about 0.9 million tons, so that domestic production was approximately 6.3 million tons, or about $88 \%$ of actual capacity and $79 \%$ of nameplate.

If the apparent consumption projections are reasonably correct, the United States will have the following choices by 1990:

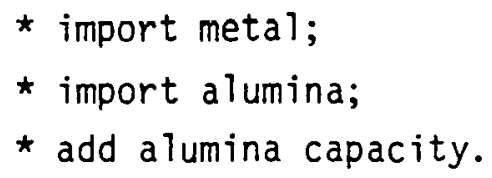

The first two options will exacerbate the balance of payments deficit, the first very rapidly because the primary metal is worth $\$ 1400$ per ton rather than $\$ 345$ per equivalent ton as alumina at 1.95 pounds of alumina per pound of metal, assuming alumina at $\$ 177 /$ ton.

Even with a substantial increase in secondary recovery, future U. S. demand is likely to require additional primary capacity, and alumina as well. Several end uses of aluminum do not generate scrap for recovery, such as construction, machinery, electrical uses and similar aluminum markets.

Automobiles do not generate aluminum for secondary recovery until they are scrapped, a period ranging from 5-7 years on average. Cars built in 1979 thus will not generate significant secondary material until 1984 at the earliest, and even 1986 or later. Any increases in aluminum use, therefore, will require additional primary aluminum, rather than recovery. The most significant source of secondary aluminum, therefore, is likely to be container scrap. 
World primary aluminum consumption is reported in the table below, by region, for the years 1975-1978.

TABLE 5.5

World Regional Primary Aluminum

Production and Consumption

Millions of Short Tons

Region

\begin{tabular}{|c|c|c|}
\hline \multicolumn{3}{|c|}{ Production } \\
\hline 1970 & 1975 & 1978 \\
\hline $\begin{array}{l}5.1 \\
2.2 \\
1.7 \\
1.0 \\
0.1 \\
0.5\end{array}$ & $\begin{array}{l}4.9 \\
3.4 \\
3.1 \\
1.9 \\
0.3 \\
0.7\end{array}$ & \\
\hline 0 & & \\
\hline
\end{tabular}

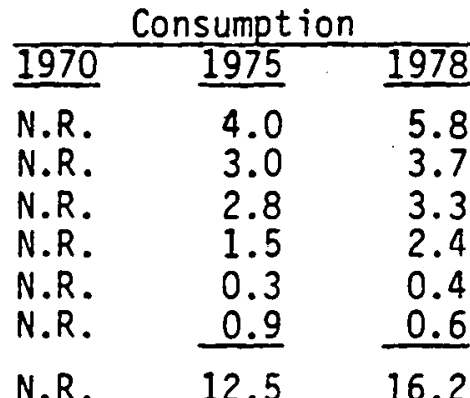

World Total

1) Canada, U. S., Mexico

2) Austria, Belgium, France, West Germany, Greece, Iceland, Italy, Netherlands, Norway, Spain, Sweden, Switzerland, U.K.

4) Australia, New Zealand, Japan, Taiwan, India, Bahrain

Source: Minerals Yearbook, Bureau of Mines; Metal Bulletin Handbook

The annual rates of change for production and consumption for the regions are shown in the table following.

TABLE 5.6

Annual Rates of Change for Primary Aluminum Production and Consumption for Selected Regions

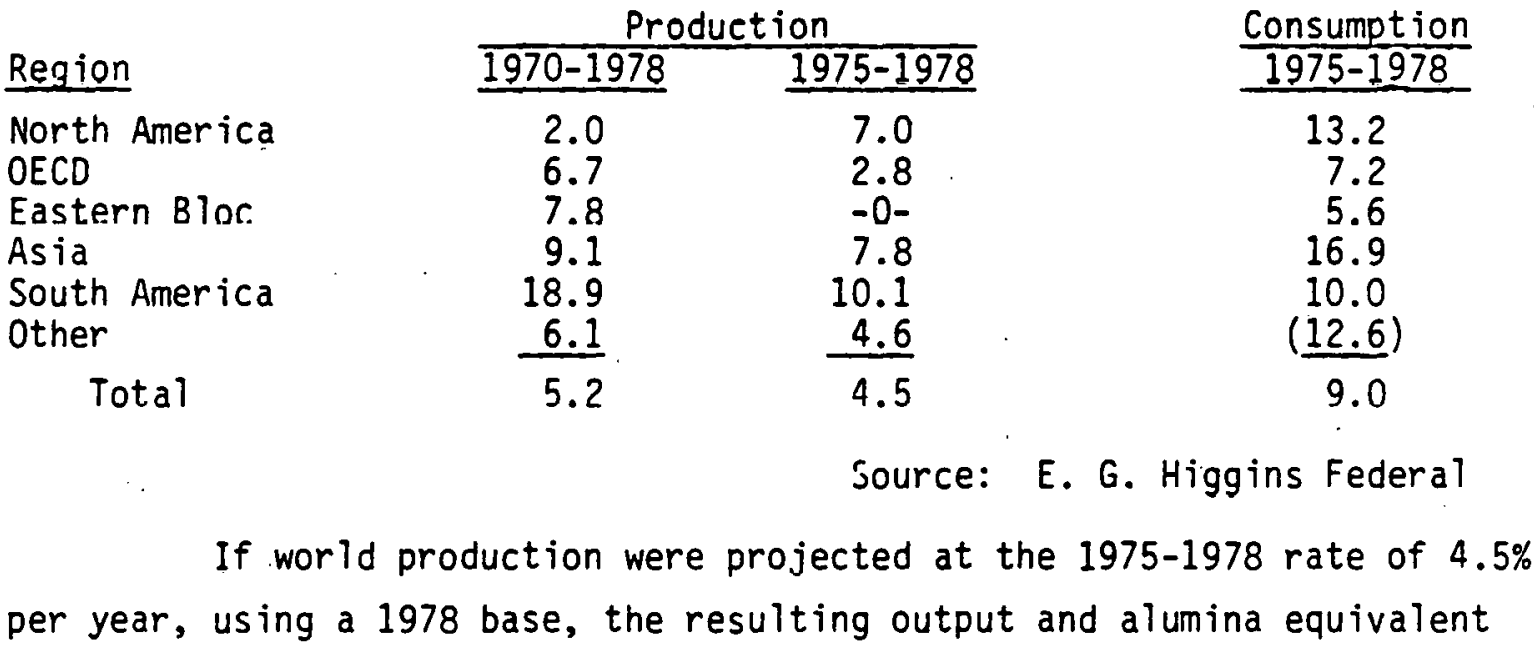


demand would be as follows:

\section{TABLE 5.7}

Projection of World Aluminum Production and Alumina Equivalent Demand

Millions of Short Tons

\begin{tabular}{|c|c|c|c|c|c|c|c|}
\hline & Item & Product & $\begin{array}{c}\text { Base Year } \\
\text { Tonnage }\end{array}$ & $\begin{array}{c}\text { \% Annual } \\
\text { Change }\end{array}$ & 1985 & 1990 & 2000 \\
\hline $\begin{array}{l}\text { World } \\
\text { World } \\
\text { N. America } \\
\text { N. America }\end{array}$ & $\begin{array}{l}\text { Production } \\
\text { Demand } \\
\text { Production } \\
\text { Demand }\end{array}$ & $\begin{array}{l}\text { Primary Metal } \\
\text { Alumina } \\
\text { Primary Metal } \\
\text { Alumina }\end{array}$ & $\begin{array}{r}16.0 \\
31.6 \\
6.0 \\
11.7\end{array}$ & $\begin{array}{l}4.5 \\
4.5 \\
2.0 \\
2.0\end{array}$ & $\begin{array}{r}21.8 \\
42.5 \\
6.9 \\
13.5\end{array}$ & $\begin{array}{r}27.1 \\
52.8 \\
7.6 \\
14.8\end{array}$ & $\begin{array}{r}42.2 \\
82.3 \\
9.3 \\
18.1\end{array}$ \\
\hline
\end{tabular}

Source: E. G. Higgins Federal

Future primary metal production capacity is most likely to be installed in areas which meet the following criteria:

* politically stable;

* low cost electric power;

* Targe bauxite reserves.

The locations which meet two or more of these criteria are:

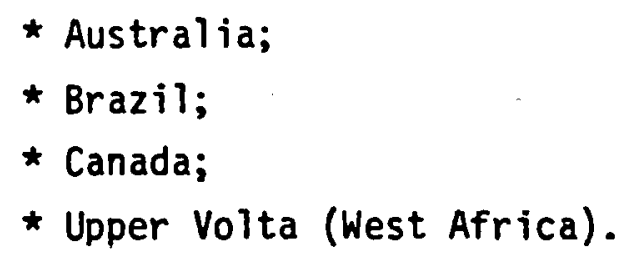

Canada has to import its bauxite, and about $40 \%$ of its alumina, but has large hydroelectric installations in Quebec and British Columbia which furnish low cost power for smelters. Approximately $85 \%$ of Canada's primary production is exported, primarily to the United States and United Kingdom.

Upper Volta is in the center of the West African bauxite reserves and has large hydroelectric potential. Extensive plans for a smelter/ hydroelectric complex have been announced and reportedly has been designed and is being constructed.

Australia is in the process of developing its large high grade coal reserves to provide low cost electric power for smelting domestic alumina produced from indigenous bauxite reserves in Western Alstralia. 
It is likely that the combination of low cost power and large high grade reserves of bauxite will result in Australia becoming a major world primary aluminum producer. In addition, its remoteness from world markets works in favor of shipping metal rather than alumina.

Brazil is also a potential major world producer of primary metal because of its large bauxite reserves and hydroelectric capacity. Of the major new regions, however, only Australia and Upper Volta are likely to be large exporters to new markets, as Canada already has well established trade patterns, and Brazil has a growing domestic use.

Soda Ash

World soda ash production and demand are assumed to be equivalent, since soda ash is not easily stored for long periods of time without deterioration due to moisture pickup. Projections of world soda ash production from historical data are shown in the table following.

TABLE 5.8

Ranked Historical and Projected World Soda Ash Production by Region

$1970-2000$

Thousands of Short Tons

\begin{tabular}{|c|c|c|c|}
\hline \multirow[b]{2}{*}{ Region } & \multicolumn{3}{|c|}{ Production } \\
\hline & 1970 & 1979 & \& Annual Change \\
\hline $\begin{array}{l}\text { N. America } \\
\text { E. Europe } \\
\text { W. Europe } \\
\text { Asia } \\
\text { S. America } \\
\text { Africa } \\
\text { Other }\end{array}$ & $\begin{array}{l}7770 \\
6500 \\
6500 \\
2980 \\
180 \\
160 \\
- \\
\end{array}$ & $\begin{array}{r}9210 \\
9730 \\
7300 \\
4470 \\
350 \\
180 \\
110 \\
\end{array}$ & $\begin{array}{l}1.9 \\
4.6 \\
1.3 \\
4.6 \\
7.7 \\
1.3 \\
\text { N.A. }\end{array}$ \\
\hline $\begin{array}{l}\text { Projected } \\
\text { Total, Summed }\end{array}$ & 24090 & 31,350 & 3.0 \\
\hline
\end{tabular}

\begin{tabular}{|c|c|c|}
\hline $\begin{array}{l}\text { Project } \\
1985\end{array}$ & $\frac{\text { ns from }}{1990}$ & $\frac{79 \text { Base }}{\underline{2000}}$ \\
\hline $\begin{array}{r}10,310 \\
12,740 \\
7,890 \\
5,860 \\
550 \\
190\end{array}$ & $\begin{array}{r}11,330 \\
15,960 \\
8,410 \\
7,330 \\
790 \\
210 \\
-\end{array}$ & $\begin{array}{r}13,680 \\
25,020 \\
9,570 \\
11,500 \\
1,660 \\
240 \\
-\end{array}$ \\
\hline $\begin{array}{c}37,430 \\
(37,540)\end{array}$ & $\begin{array}{l}43,390 \\
44,030)\end{array}$ & $\begin{array}{c}58,320 \\
(61,670)\end{array}$ \\
\hline
\end{tabular}

Data Source: Bureau of Mines, Mineral Commodity Profiles, Minerals Yearbook; Projections, E. G. Higgins Federal

World soda ash production on the following page for the same regions in 1985. 
TABLE 5.9

Projected World Soda Ash Production Capacity, 1985

Thousands of Short Tons

\begin{tabular}{|c|c|c|c|c|c|}
\hline Region & Produ & jected 1985 & & $\frac{\text { Projected }}{\underline{1985}}$ & $\frac{1 \text { Production }}{1990}$ \\
\hline N. America & $\begin{array}{l}\text { Natural } \\
\text { Synthetic } \\
\text { Total }\end{array}$ & $\frac{(11,300)}{\left(\frac{2,000)}{13,300}\right)}$ & & $\begin{array}{r}9,310 \\
\frac{1,000}{10,310}\end{array}$ & $\begin{array}{r}10,830 \\
560 \\
11,330\end{array}$ \\
\hline $\begin{array}{l}\text { E. Europe } \\
\text { W. Europe } \\
\text { Asia } \\
\text { S. America }\end{array}$ & $\begin{array}{l}\text { Synthetic } \\
\text { Synthetic } \\
\text { Synthetic } \\
\text { Synthetic }\end{array}$ & $\begin{array}{r}12,530 \\
9,040 \\
4,670 \\
700\end{array}$ & $\cdot$ & $\begin{array}{r}12,740 \\
7,890 \\
5,860 \\
550\end{array}$ & $\begin{array}{r}15,960 \\
8,410 \\
7,330 \\
790\end{array}$ \\
\hline Africa & $\begin{array}{l}\text { Natural } \\
\text { Synthetic } \\
\text { Total }\end{array}$ & $\begin{array}{l}520) \\
180) \\
700 \\
\end{array}$ & & $\begin{array}{l}- \\
\overline{190}\end{array}$ & $\begin{array}{l}- \\
210 \\
\end{array}$ \\
\hline \multicolumn{2}{|c|}{ World Nameplate Total } & $\overline{41,640}$ & & $(\overline{(41,710)}$ * & $(\overline{(48,920)}$ * \\
\hline \multirow{2}{*}{\multicolumn{2}{|c|}{$\begin{array}{l}\text { World Effective Capacity } \\
\text { * Nameplate capacity needed } \\
\text { to attain projected production }\end{array}$}} & 38,310 & & 37,540 & 44,030 \\
\hline & & & : & $\begin{array}{l}\text { U. S. Bu } \\
\text { Minerals } \\
\text { files; M }\end{array}$ & $\begin{array}{l}\text { of Mines: } \\
\text { modity Pro- } \\
\text { als Yearbook }\end{array}$ \\
\hline
\end{tabular}

If all projected capacity is installed, and no outmoded facilities closed, there will barely be sufficient capacity to meet projected demand at historic growth rates, and assuming nn unusual new uses.

If there are any changes in this picture, they are likely to be in the direction of less rather than more capacity in Europe, both Eastern and Western. As can be seen, the combined total projected capacity is barely larger on a nameplate basis than projected production. It is likely, therefore, that some shortfall could exist. If Eastern. Europe cannot meet the ambitious capacity projections, then there would be a deficiency.

The only region with surplus capacity is North America, which, with the exception of two million tons of Solvay process plant capacity, would be one of the lowest cost producers, excepting Kenya.

The potential for export ash sales is considerable for the U.S., and both Trona and oil shale should be able to participate equally in this market since the manufacturing costs which have been estimated are comparable. 
U. S. soda ash exports have climbed steadily since 1970:

TABLE 5.10

U. S. Soda Ash Exports

Thousands of Short Tons

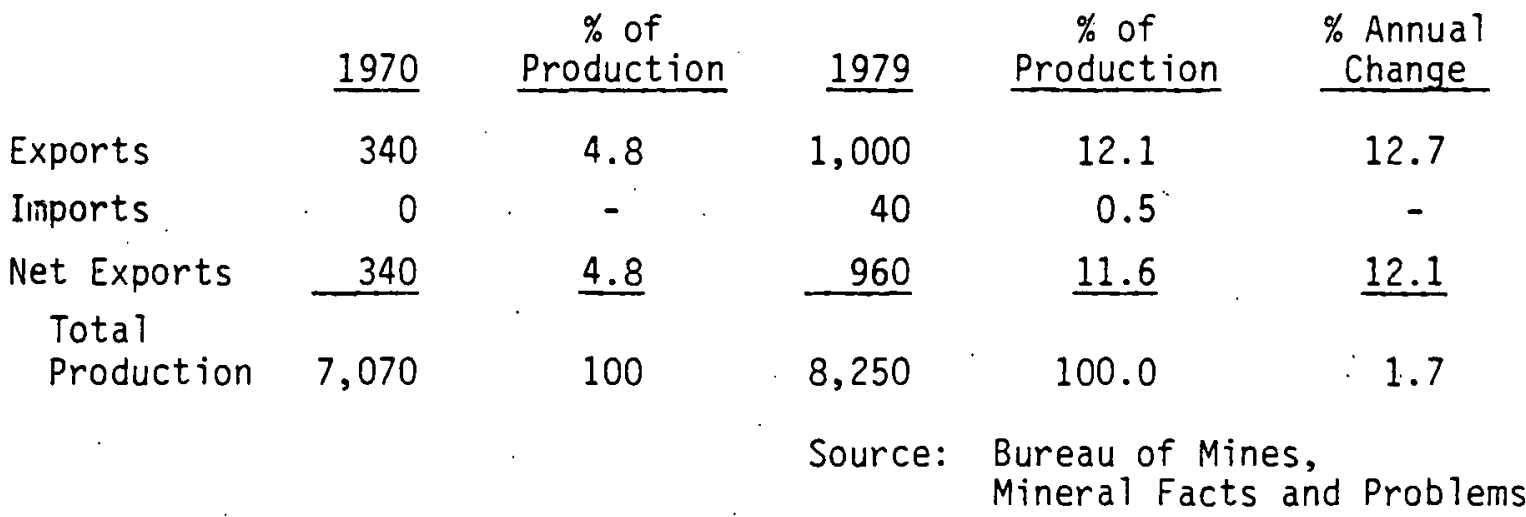

If exports were projected forward at the same rate, they would present the following picture:

TABLE 5.11

Projected U.S. Soda Ash Exports and Production Thousands of Short Tons

\begin{tabular}{|c|c|c|c|c|c|}
\hline & 1979 Base & $\begin{array}{c}\% \text { Annual Change } \\
1970-1979 \\
\end{array}$ & 1985 & 1990 & 2000 \\
\hline Production & 8,250 & 1.7 & 9,100 & 10,000 & $11,800^{\star}$ \\
\hline Exports & 1,000 & 12.7 & 2,000 & 3,800 & $12,000^{\star}$ \\
\hline \multicolumn{6}{|c|}{$\begin{array}{l}\text { *Assumes either production capacity will } \\
\text { be increased for Trona or 0il Shale, or } \\
\text { both, or exports will be limited to the } \\
\text { difference between domestic demand and } \\
\text { production capability. }\end{array}$} \\
\hline
\end{tabular}

Source: E. G. Higgins Federal

The potential export market for U. S. based soda ash was estimated to be 5,000,000 short tons by 1990 . This was based upon sales as follows:

\begin{tabular}{llll} 
Market Type & Region & Tonnage & Projection Assumption \\
${$\cline { 1 - 1 }$} }$ & Western Europe & $-3,000,000$ Growth and Solvay Shutdown \\
Domestic & Japan & $-1,000,000$ Displacement and Growth \\
Export & Eastern Europe & $-700,000$ Displacement from W. Europe \\
Domestic & Australia & $-\frac{300,000}{\text { Al Alumina }}$ \\
& Total & $5,000,000$
\end{tabular}


No assumptions were made for modè of entry since this was a marketing decision which can only be made by the firms which might be involved.

The production projections are based upon historical domestic demand, plus exports. As can be seen, if export sales were to increase very much, and if Solvay process units in Canada and the United States were closed, there would be some question as to whether there would be sufficient trona capacity to meet both requirements without major new investments.

It would appear, therefore, that oil shale based soda ash could be expected to be able to enter the export market at least, and possibly share in domestic growth. 
1. Colorado School of Mines

2. Mains, Charles J. - "Dawsonite and Nahcolite - an Overview", 83rd National Mining Conference, February 6-8, 1980, Denver, Colorado

3. Mains and Farris - "Dawsonite and Nahcolite Survey" - Volume 1, Colorado School of Mines Research Institute, EC 775071683

4. Business Week, January 29, 1979

5. European Chemical News, September 15, 1978

6. European Chemical News, April 23, 2976

7. Organization for Economic Cooperation and Development - East/West Trade 1980, p. 45

8. Ibidem - p. 47

9. Fortune Magazine, July 28, 1980, "Russia's Sudden Reach for Raw Materials"

10. OECD 1980

11. U. S. Bureau of Mines, Minerals Yearbook, 1976 - "Bauxite"

12. Bell Journal of Economics - "Cartel Pricing and the Structure of the World Bauxite Market" - Robert S. Pyndyck, Autumn 1977

13. U. S. Bureau of Mines, Cost Estimate for Producing Alumina by the Bayer Process, Peters, Johnson and Kirby

14. Bureau of Mines, Mineral Commodity Profiles, MCP \#14

15. U. S. Bureau of Mines, Minerals Yearbook 1972, p. 204

16. Ibidèm

17. U. S. Bureau of Mines, Cost Estimate for Producing Alumina by the Bayer Process, Peters, Johnson and Kirby

18. Chemical Process Industries, p. 435

19. Metals Bulletin, Statistical Annual 1979, Non-Ferrous Metals

20. U. S. Bureau of Mines, Mineral Industry Surveys, January 1980

21. Ibidem, January 1979

22. Metal Statistics, Annual Mining Review, 1979

23. Ibidem

24. U. S. Bureau of Mines, Minerals Yearbook 1973, "Bauxite"

25. Chemical Engineering, June 16, 1980

26. International Magnesium Association

27. Chemical \& Engineering News, June 30,1980, p. 24 
28. Light Metal Age, Apri] 1979, "Aluminum Present Trends and Glance at the '80s", Munera, G.

29. AiChe - Fuels and Petrochemicals Division, 88th Annual Meeting, "PET in the Container Market", R. Gutekunst

30. Wall Street Journal, June 13, 1980

31. OECD - East/West Trade 1980

32. Manufacture of Soda, T. P. Hou, p. 45

33. U. S. Bureau of Mines, Mineral Facts and Problems

34. Chemical Marketing Research Association, Review and Forecast, May 2, 1980, "Fiberglass Reinforced Plastics - Materials for the Times"

35. Chemical Process Industries, R. Norr is Shreve, p. 259

36. Bureau of Mines, Minerals Yearbook 1977, "Sodium Chemicals"

37. Chemical Process Industries, R. Norris Shreve

38. Chemistry and Technology of Lime and Limestone, R. S. Boynton

39. Pulp and Paper Manufacture, Vol. I, "Preparation and Treatment of Wood Pulp, McGraw Hill

40. Chemical \& Engineering News, February 4, 1980, p. 10

41. Ibidem, JuTy 7, 1980 "Key Chemicals"

42. Ibidem, July 28, 1980 "Plastics Demand Drops Sharply, p. 16

43. Ibidem, June 6, 1980 "Ethyl to Shut Down Anti-Knock Plant"

44. Ibidem, June 30, 1980 "Polyurethane Use May Grow 9\% Annually"

45. Business Week, May 16, 1980 "When Natural is Cheaper than Synthetic"

46. Electric Power Research Institute, "Status of Flue Gas Sludge Fixation" January 1979

47. American Gas Association

48. The Potential for Energy Conservation in Nine Selected Industries, Vol. 7, pp. 243-618, Gordian Associates Inc.

49. U. S. Bureau of Mines, 1977 Minerals Yearbook 